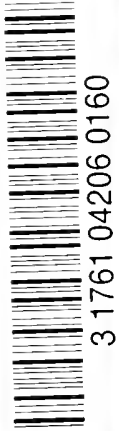



Digitized by the Internet Archive in 2010 with funding from University of Toronto 



3

THE

INSULAR GREEKS 
LONDON : PRINTED BY

SPOTTISWOODE AND CO., NEW-STREFT SQCARE

AND PARLIAMENT STKEET 



\section{THE CYCLADES}

$\mathrm{OR}$

LIFE AMONG THE IVSULAR GREEKS

BV

J. THEODORE BENT, B.A.OXON.

AUTHOR OF

'GENOA: HOW THE REPLPLIC ROSE AND FEIL'

EIC.

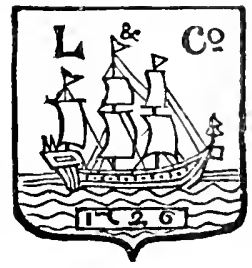

LONDON

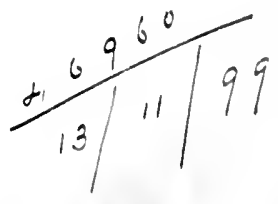

LONGMANS, GREN, AND CO. 1885 



\section{PREFACE.}

The Islands of the Egean Sca offer plenty of scope for the study of Hellenic archeology, but they are more particularly rich in the preservation of manners and customs which have survived the lapse of years; and the result of a special study of both these points, made during two winters passed by my wife and mysclf amongst the islanders in their distant hamlets, and in their towns by the sea-coast, I here place before the public.

The causes which have conduced to making the Cyclades a favourable field for the study of Hellenic folklore are these: First, the islands were never, like the mainland, subject to the incursions of barbarous tribes; this fact is especially noticeable in the island of Andros, the most northern and the most accessible of the Cycladic group from the mainland by way of Euboa. The northern portion of this island is cxclusively Albanian in spech, manners, and customs. The Grecks in the south are highly influenced by this intermixture, which has in a measure destroyed the identity of the continental Greeks; but here the Albanian wave has ended, there is not a trace of it in any other of the Cyclades. 
Secondly, the Italian influence which was dominant in the Middle Ages in the Cyclades has left traces which extend littlc beyond the towns on the sea-coast. The Latin rule seems to have been a mild one, but unpopular amongst the Grecks ; religious feeling between East and West ran high, and each party throughout retained their customs and their cult. At Naxos, for example, there are still existing many families of Italian origin who retain their religion; they reside almost exclusively in the chief town. The sailors, in their dialect, have quantities of Italian words, but up in the mountains of Naxos, a few hours' distance from the town, the villages are inhabited by Greeks of the most uncloubted pedigree. It is the same at Santorin, where the Italian influence was equally pronounced. If you leave the towns and go into the villages, you find customs existing the very nature of which stamps them as Hellenic.

Thirdly, during the Turkish times the Cyclades were hardly ever interfered with, and if they annually sent their tribute to the Kapitan Pasha when he anchored off Cape Drio of Paros to collect the revenues, the islanders were practically allowed self-government. It was not so with the Sporades, which are far more productive and easier of access. Chios, Lesbos, Samos and others are perfect gardens as compared with the Cyclades; and to the smaller islands of the Cycladic group, such as Ios, Sikinos, Pholygandros, some of which appear to have becn uninhabited, or ncarly. so, during the Latin rule, refugees came and settled about this time from all parts of Greece. The Cretans, the Peloponnesians, and the inhabitants of Asia 
Minor, to escape from Turkish oppression, built walled villages up on the hills to protect themselves from pirates, and there they have maintained their customs undisturbed ever since.

From these facts it will be obvious that these islands, especially the smaller ones, offer unusual facilitics for the study of the manners and customs of the Grecks as they are, with a view to comparing them with those of the Greeks as they were. The mainland of Greece has been overrun by barbaric tribes: the Ionian islands have been thoroughly Italianised: Greece in Asia Minor, and the islands adjacent to the coast have been swamped in Islamism : yet the Cyclades have remained more or less as they were, thanks to their insignificance and unproductive soil.

I did not find much literature to assist me in my researches. Tournefort's 'Travels in the East' was a pleasant companion, adducing quaint historical facts and showing us what the islands were like at the end of the seventeenth century. Ludwig Ross, in his Inselreisen, guides the traveller to the principal points of antiquity, which were discovered fifty years aģo. Bernard Schmidt's Volksleben der Neugriechen formed an excellent basis on which to start inquiries about the manners and customs; but as his material was chiefly culled from the Ionian islands and the mainland, I found a vast difference existing between the customs he has collected and those of the Cyclades. Von Hahn's collection of fables, Wachsmuth's work on Greek folklore, and one or two others of minor importance, I found very uscful 
for suggesting remarks, and these invariably provoked a discussion whence the genuine local customs were learnt.

But personal intercourse with the islanders in all grades of society, at their work and at their board, proved to us the most infallible method of understanding their life and their superstitions as they exist to-day ; and the kindly hospitality with which they received us, and the surprise they evinced at seeing for the first time amongst them an English lady, will remain for ever fixed on our memories. My first experiences were made with the assistance of a dragoman ; but, on better acquaintance with the language, I learnt to despise his services, and took as servant a native of one of the islands, who became invaluable in assisting me to discover points of folklore which without him it would have been impossible to arrive at.

\section{J. THEODORE BENT.}

13 Great Cumberland Place, IV.

November iSS4.

I beg leave here to acknowledge the kindness of Messrs. Macmillan, who have allowed me to reprint, under a slightly enlarged form, my articles entitled, 'A Panhellenic Festival,' 'Easter Week in Amorgos,' 'The Capital of the Cyclades,' which appeared in their magazine, and the article which has been published by them in the Hellenic Joumal respecting my excavations at Antiparos; also that of Messrs. Chatto \& Windus, for allowing me to republish an article which appeared in the Gentleman's Magasine under the title of 'In Greek Waters.' 


\section{CONTENTS.}

\section{CHAPTER 1 .}

SERIPHOS.

PAGE

The frogs-Captain George-Danaë and Perseus-Appearance of town-The little plain of Livadhi-Tomls in fields-St. Isidoros -St. Tryphon and Apollo Smintheus-Captain George's house and wife-The game of the swing - The King of Seriphos-Few antiquities in Seriphos-Start for convent of Archangel Michael and Galene-Winepresses-Process of making wine-Cerenonies at time of firstfruits-Planting of vineyards-Preparing of tools before sowing of seed - The Transfiguration basket-The convent frescoes-Galene, the old demarch and his presentimentsStories of Nereids-Stories of old Plyntes and old Stavris-The superior of the convent tells us about the history of two lampsHospitality at Kalosis - Draught mills-Inscription-Nagnet mines-The white tower-Difficulty in leaving Scriphos . .

\section{CHAPTER II.}

\section{SIPHNOS.}

The sponge-fishers and their $\kappa a$ ua $-\mathrm{N}$ ight in the potter's shed-II is bed and board - The potters of Siphnos-Their wheel-Barren spot-The centre of Siphniote life-The pigs-Captain George's riddle-Apollonia-Captain Prokos, his family and his houseThe temple of the nymphs - Genii loci-Food to propitiate themHamadryads-Arabs-Nunnery of St. John the Theologian-Its origin-Western influence in Siphnos-The School of the Holy Tomb, its foundation and results-Chrysogelos-The Kastro- 
Italian town-Inscriptions-Old houses and old costumes and jewellery-Ruins of Hellenic town-The mines-Herodotus on the ancient Siphniotes-At the monastery of the well - Pronunciation-Intrusive pig-Visit to Pharos-The nunnery of the Virgin of the Mountain-Kypriani-Luxuriance of vegetation-harbour and monk of Bathy

Note on the Ancient Gold and Silver Mines of Siphnos . $\quad$\begin{tabular}{ll}
$2 \mathrm{I}$ \\
\hline
\end{tabular}

\section{CHAPTER III.}

\section{KIMOLOS.}

Volcanic nature of island-'Terra Kimolia'-Donkeys and their saddles--The town and our accommodation-The sacrariumVampires and priestly exorcisms - Other superstitions - Mrs. Gamp and the Nereids-St. Katharina's Day-Sailor struck by Telonia in the church-Recipe for love cakes-The Kimoliote costume-Visit to the old camp-Lunch at a mandra-View over the island from the old camp-Incantation to cure headacheTo cure paleness and warts-Antiquity of charms-Adieu to Captain George-Visit to the ruins at Hellenikà-Mr. Brest's excavations - Daskaliò-Crossing to Melos

\section{CHAPTER IV.}

\section{MELOS.}

The sun and his mother-Winter storms-Apollonia--Melos by moonlight-Our muleteer's astrology-Refuge in a cave-Our reception at the capital-Horseshoe shape of Melos-French corsairs and prosperity of the island-The corsair Capsi-Cause of decay of Melos-The number of churches and their peculiar names--View from Acropolis-Surrounding villages-The costume-Objects of interest at Trypetè-Nychia and Plaka-Exposure of delicate children-Vanis-The deserted western horn of Melos-Expedition to the Convent of the Iron St. John-Wild mastic berriesOur girl botanist-Mount Prophet Elias-Numerous cairnsLegend of the convent--Erinomelos and mouflon-Convent of St. Marina-Natural Turkish bath-Deserted Zephyria-Old Kromidonis and his reminiscences-Priestly curses-Pestilences and methods for checking them--Euphemisms for diseasesCaves by the sea-Port of Adamantas-Church-Delay there 
-Cotton-spinning-Greek music-Fables-The fable of the twelve months $. \quad . \quad . \quad . \quad . \quad . \quad . \quad$.

Note on the Antiquities of Melos: The ruins in the vale of Klima-The finding of the Venus of Melos and the statue of Poseidon-The catacombs

\section{CHAPTER V.}

\section{ANAPHI.}

Legend of Anaphi-Prophet Elias and the sun god-Measurement of light-Arrival at Anaphi-Night in the church-The partridges of Anaphi-Reptiles-The town and its isolation-- The name of Chalaris-IIandsome people-Eutimia-The costume-Old Chalaris and his antiquarian interests-No doctor and longevity - An Anaphiote cottage-Good bread-Anaphi independent of the world-The Crispi castle-The Russians-Wet morning-

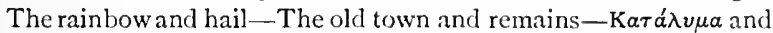
its limekiln-An island plough-Nereids of the sea-The Lamix -A dance at Anaphi-The syrtos, the systa, and the moloritisAndronico's song and dance-Visit to the convent and ancient temple of Apollo. Eglites-Inscription in a ruincd house . .

\section{CHAPTER VI. \\ SANTORIN (THERA).}

\section{The Volcano.}

Description of the volcanic cluster-Mesa Bouno and Monolithos - Chasms-The earliest eruptions-Excavations on TherasiaAuthorities for the eruption in 198 B.c. - The name of TheraThe eruptions in 60 A.D. and 726 A.D. - That of 1457 and $1573-$ Father Richard's account of the terrible one in 1650-IIS. accounts of eruption in $\mathbf{1 7 0 7 - S c i e n t i f i c ~ o b s e r v a t i o n s ~ i n ~} 1866-$ The prospective danger-Effect on the inhabitants-Extent of this effect-Effect on vegetable life-Superstitious dread, and story of old Laimos

\section{The Island of Santorin, or Thera.}

First impressions-The port and houses-The cliff-Expressive words -The eparch-Phera-St. Irene-Expedition to and ascent of the 
volcano-Roman Catholics here-Walk to Scaros, Meroviglia, and Mount Jupiter-Across the plains and vineyards-Vinegrowing-Cisterns and lack of water-Gonia and houses in the rock-Bothrò in a chasm-Description of the houses-The damp --Our shoemaker's songs - Santoriniote wit and thriftinessVintage festivity-Church of Bothrò-Expedition to Pyrgos and Mount Prophet Elias-The view-Sport in Santorin-Akroteri and the Greek calends-The old woman's alarm-New ycar festivities-Cheesecakes-The leper hospital-Black dresses of the women-Cold-Expedition to Epanomerià-Nautical customs-Roman tombs-A wedding at Santorin-Intrusion on the bride-Music-Gun-firing-The honey ceremony-Music ceremony on making the crowns-Procession to church-Religious ceremony and the dance afterwards--Other wedding customsThe proposal-Expedition to Emporion-The old church there, and ceremony of blessing the waters-Torrents of rain-Basket industry-Expedition to Therasia-Blessing of the sea-Breakfast at the demarch's house-Quaint village of Agalià-Search for our drunken sailors-Symposia-The Lamia of the sea-Ideas on wind-Our sailors' fight, and dangerous passage . . .

Note I.-On the Antiquities of Santorin: Private collectionsRuins of Eleusis-The serpent-The heroa-PerissaRuins on Mesa Bounò of the town of Thera-Roman renains at Kamaris

Note II.-On the Prehistoric remains at Therasia: Discoveries of houses beneath the pumice stone-Utensils found in them compared with those from Antiparos and Akroteri .

\section{CHAPTER VII.}

IOS (NIO).

The steamer Fanhellenion-Little Malta-Our new friends-Costume in Ios-The town and our house-Old costume-Aiysethra-The supposed tomb of Homer-Plaketos and its cottages-Games played by muleteers - The girls and their divinations-Expedition to the old Frankish town-Marble mountain-Family church and feast day-Roman remains-The church of the Holy Theodote and the panegyris-Our evening amusements-Various kinds of games 


\section{CHAPTER VIII.}

\section{STORM-STAYED AT SIKINOS.}

No harbour in the island-The fleet-Parren shore--The two villages -The Cretan refugees-Our jovial host-The Castro-Blessing the sea-The superstition about sores and linen-Bird-blindnessThe northern coast-Visit to the church of Episcopi-The owner's cell, and the fare he has to give us-The storm comes on-Our hilarious host-The former demarch takes us to his garden and house-The old monastery on the top of the hill-The birth in Sikinos-Male children-Superstitions-We visit the mother, and are present at the washing and blessing ceremony-The demarch's information about births-St. Eleutherios-The virgin's hand and hair-The baptism ceremonies connected with it-The

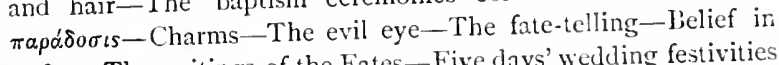
Moipo-The writings of the Fates-Five days' wedding festivities -The dancing-Pack-saddle dance . . . . .

Note on the Temple of Pytrian Apollo and the old Town of Sikinos

\section{CHA P TER IX.}

\section{PHOLYGANDROS.}

Long sail-Magniticent coast scenery-Mysterious arrival and climb to town-Our new host-Modern ideas-Power of an island demarch-Democrats and aristocrats-Politics-Excess of rivalry - The grief table and food of woc-How the old man received the prayer oil-All Saints' Day and Kó $\lambda \lambda \nu \beta a$ - 'Inside' and 'Outside'-Baking day and ovens--Old ruins-Visit to the golden grotto-Southern harbour-The uses of the gourd-Stupendous coastline-Terrible climb and alarm of the demarch-Ancient cisterns inside-Form of Pholygandros-St. Eleutherios and the historical association-Pholygandriote society-Dr. Venier and his treasures - Jealousy of our hostess - Dinner party with Themistocles Mavrojenes-Our boatmen dye their sail-Our ballast increased-Difficultics of our voyage . • . 


\section{CHAPTER $\mathrm{X}$.}

\section{THE DEATH-WAILS OF MYKONOS.}

Osier bulwarks and horn sail-rings-Hydriote boats-Approach to Iykonos-Appearance of town-St. Nicholas and PoseidonOur friend Paleologus-The Monk family-Deaths-The lamen: for those who die abroad-Modern ideas of death-Charon, Tartarus, Hades, Phlegethon, and Lethe reproduced-Description of Charon from lamentations-Death of young ParodosPrayer oil-Melting of salt-Death agonies and their significance - The marologista Zachara-The makranades and costume of Mykonos-Love for marolosia - The Marseilles merchant-The funeral-Distressing scenes at the lamentations-Zachara's songs -Refreshments and renewed grief-A second marologista comes in-Breaking of the jug-Funeral procession-The last hissBurial-Cleansing the house-The bitter table-The Kó $\lambda \lambda \nu \beta a$ and blessed cakes-Grief renewed at intervals-Distribution of food- . A second lamentation-My awkward position-The sister's grief - Mykonos itself-Few traces of antiquity-Delos the centre of attraction-Local museums-Expedition to Tourliani-Fertile homesteads-Mrs. Monk's treasures-Marousa the witch-A prescription for a love potion

Note I.-On the Museuns of Mykonos. . . . . . $22 \mathrm{~S}$

Note II. - The Excazations at Delos . . . . . 229

\section{CHAPTER XI.} TENOS.

\section{The Panhellenic Festizal.}

Love of the panesyris-Polytheism-The Madonna of Tenos-Vast concourse of Greeks-List of miracles-Political aspect of the feast-St. Nicholas at Tenos-Discovery of miraculous picture in I \$22-Cleverly contrived plan-Debt of gratitude owed to religion-New theories on old bases-Voyage from Athens-The crowds on hoard - Honey and milk - The crowds of pilgrims and their presents-Scene on the way from the pier to the churchAppearance of the church-Pillas from Delos-The holy of holies-Silversmiths-Baptisms, and struggles to be god-parents - Weighing a baby and candles-A Turk's offering-Receiving 
offerings-Cures for blindness-Night scene in church-'Eyko'. $\mu \eta \sigma \iota$ - In the vaults below-Handkerchiefs on candlestickCotton wool-Pilgrim wit-Scene in the town-Cleaning of the picture - Private ceremony - The procession-Departure of pilgrinıs-Miracles

\section{The Island Itself.}

Difference of scene a year later - The town of St. Nicholas-Antiquities -The dovecotes - Exóburgo-The view-Strength of positionHistory-The cowsheds-Loutrà-Miss Leeves' establishmentCarved fanlights-Clean Monday-Visit to a nunnery-The hours - The lady superior - The nuns' cells - Constitution of nunneryFasting - The charnel house-Hill rillages-Festivities-Dancing on roof-The carnival dance-Teniote mules-Kardiane-The winds-Kù $\rho$ Bopéas-Hysternia-Pyrgos and its marble-Charms

\section{CHAPTER XII.}

\section{ANDROS.}

\section{Eastern Andros.}

Picturesqueness and fertility-The eparch-An Andriote luxuryLemon and mulberry trees-Quaint custom-The old townFertility of the plain-Lenten fasting-Pig-killing-Old church at Messarià-The paradise of Menites-Lofty towers-The archons and their family pride-Customs-Temple of Dionysos-Andriote janıs-Monastery of Panáchrantos-The austere superior-Night there-Our frugal meal-Danı cell-Early mass-The church-Silver treasures-Miserable journey to Korthl-Aedonia-Night in a tower-Demarch Käres - Theophilos Kaïres and his orphanage-The vale of Korthl-No traces of antiquity on the eastern side

2. Western Andros and its Antiquities.

Difference between Western and Eastern Andros - Greelis and Albanians-Gyaros-Site of the old town-Our quarters there$\phi \lambda \grave{a} \tau s$-Ruins-Legend of two towers-Cirls and the olive twigs -Albanians-Mpatzi-Fishing boats-Shellfish_Attack of fever -Gavrion-The north winds and threshing floors - The character of the inhabitants-Expedition to Phello-Narble quarry-The tower of St. Peter-Monastery of I Iagia-Comfortable quarters- 
The Bishop of Stavropolis and his book-The sacred source-Was this the temple of Dionysos? - Age of monastery-The libraryInteresting MSS. - Katikoilos and our strange host-The motherin-law and her superstitions-Andriote hospitality-Lamyra, and how we were entertained there

Note on the Round Hellenic Tower of Andros . .

\section{CHAPTER XIII.}

SYRA, THE CAPITAL OF THE CYCLADES.

Cause of its growth-Appearance of Hermoupolis-Barren rocksHomer's description-How accounted for-Life and colouring in Syra harbour - Gay appearance of the quay-The fish marketHotels-Roman Catholics have made Syra-French protectionGreek freedom produces a new era-The Chiote refugees settle at Tenos and eventually at Syra - Hermoupolis foundedIslanders weak-minded in revolt-Colonisation of Syra-Neutrality, but supplies of money sent - The first two-storied houseChristening of Hermoupolis - Church parliaments-Pirates disturb commerce-Growth of Hermoupolis- Why Greece has not answered expectations-Description of town-Visit to the university and the archbishop-The newspaper Pherecydes-Traditions-The theatre - The west end - Roads and carriages-Visit to Delle Grazie - Two ancient cities-Merchants' gardens-Feasts of Dionysos-Upper Syra, convent, and riew-Sentimental young lady-Expedition-Rough mule-track-An old manLegend about old age-Homer's lines-Herdsmen-Goat-bells --Some strange words-Grammata Bay and the old rock inscriptions-Chryse and Talant

\section{CHAPTER XIV.}

NAXOS.

\section{An Historical Sketch.}

Importance of Naxos-Difference letween town and mountain lifeGreck influence on Venice-Latin line of dukes-Our authorities -Rancour between Greek and Latin-Marco Sanudo's conquest -Duke Spezzabunda-The Crispi family-Constant struggles in 
the islands-Turkish inroads-Duke Jolın's dilemma-Duke James, the last of the Crispis-The great Jew Joseph-Coronelli and Turkish agas-The Latin nobility-Jealousies-The Latin: of the upper town.

\section{The Town of Naxia.}

Difficulty of getting a lodging-Our house and host-Christmas EveIsland T⿱丶万 The harbour-St. Dionysius and Dionysos-St. Demetrius and Demeter-Place names-Arrival of the steamer-The cycloneOur miseries-Idleness of Naxiotes-Paying visits-The bishop explains sacerdotal robes-The mariner's love song-Greek Christmas-IVe surprise the nuns of St. Chrysostom .

\section{In the Mountains of Naxos.}

Difficulties of the road-The soil washed down - The wine of Dionysos - Richness of plain - A lovely villa-Three villages of Potamia - We halt at Mesopotamia-Luxuriance of country-I)reary reception--Our palace-Ancient fortress-Legends connected with it-Hidden treasure-We quarrel with the Potamiotes-The vale of Trajaia_-Our jovial host Gabalas-Bencath our bed - Churches at Chalki-Gabalas' riddle-Philoti, our tower and food-The kindly priest-Robbers, and the old woman's pig-Ill-natured legend-A wine syphon-Lovely day-Ascent of Mount Zia--

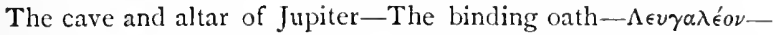
The tower of the winter torrent - Apeiranthos-Evil appearance of people-Our friendly host-Cretan origin-Their dialect and dress -The lyre-Cold mountain ride-The dancing place of the winds -Komiakè-We make ourselves at home-Wretched village-. Kalkagári-Their attributes-Colossal statue of Apollo-The marble hill-Unfinished statues-A death and its cause-The funeral and the wailing-The obolos for Charon-Belief in Charon-Convent of Phaneromène-Monkish prudery-The narthex-Papa Andréas and his daughter-Gaicty at EngarraisThe tirliz dance - Dance of the Kalkagári-Games- - úra'Barrels'-Cock-fighting-Packsaddle-The 'bee'-Old dressA regma-Tripodes and the remains near it-Galualas' lambThe shocmaker of Leonides 


\section{CHAPTER XV.}

PAROS.

The abundance of marble and ancient remains-Paros a centre of commerce in all ages-Paroikia-Unhealthy marsh-Names of churches--The drunken St. George-St. Nicholas' Eve-A

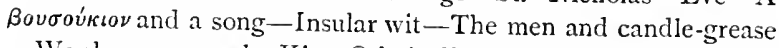
- We share our meal-King Otho's dilemma-The Church of the Hundred Gates-The narthex, the chapels, the sanctuary, and circular apse-The marble baldacchino-St. Theoctistas' footstep and spindle-Musical challenge-Sarcophagi-Necropolis of Paros-Amongst the ruins of Paroilia - The temple of Demeter and Miltiades--Houses of the Crispis and Veniers--The tranway - The Belgian marble company-The lychnites-Beehives-The quarries - The shafts-Signs of ancient work-King Otho's visit - The bas-relief-Leukis-The church-Orange and lemon groves -Superstition about wells and $\sigma \tau \rho^{\prime} \gamma \lambda \alpha \iota-M o r e$ about Kalkagári -An entertaining evening and generous host-Across the mountains-The abys- Kypedos and the medieval fortress-The church and its decaying decorations-Graves-Marmora and temple of Marpessa-Naoussa and its harbour.

PAGE



\section{CHAPTER XVI.}

\section{ANIIPAROS.}

\section{The Island and the Grotto.}

An island without a history-The contenpt of the Pariotes-The crows and the swans-The pirates' haunts-A lucky windfall-The wretched town-The priest-The old wizards and their divinations-Dancing and song-Idleness-Visit to the grotto-Appearance of mouth-Traces of antiquity-Perils of the way-The illumination and effect-Popular dread-Curious belief-The hall - Resemblance to a church-M. de Nointel's Christmas massHis retinue-Their names-King Otho again-The ascent-Our effering to St. John

Note on the Prehistoric Remains of Antiparos: Excavation and discoveries-Difficulty of assigning date-Argument from analogy of remains at Santorin 


\section{Zeppo's Story.}

Fisling in Greek waters-Zeppo's appearance-Explanation of locality -Despotiko and Strongylo-Octopus-fishing - Zeppo begins his story - Andronico's mandra and the church - Zeppo's night therein-We fish with dynamite-Zeppo and the robbers-We have our lunch-What they did with Zeppo-We find some seals -Zeppo on Strongylo line-fishing-The scaros and its gallantryTunny-fishing-The sequel of the story from Mrs. Zeppo .

\section{CHAPTER XVII.}

\section{KYTHNOS (THERMIÀ).}

Bay of Hagia Eirene- $\Lambda$ departure and a return-The café at the port - The hot baths of Thermia-The new building-Messaria - The Jew-Costumes-Wretched town-Its origin-Vicissitudes of a one-citied island-The Frankish town-Legends about it-The Cretan colonists-The Virgin of Athens- $\Xi \delta a v a$-The Ist of March - The swallow festival - Customs on May I-Good Friday-New Year's Eve-Charms-The plague of Loutso-Former fertilityChildren's ailments and novel cures-Fevers and consumptionReligious ideas-Serpents in houses-The wine and the cheese of Kythnos-Cheese Sunday-Bryocastro-Suggestion as to name - The washerwoman-The old town-The Dragon's HouseRoman days-The false Nero-Broukolakes-Curious reservoir -Frankish fortress-A shepherd's hut-Stlakka-Its position - The demarch receives us-The cave-Ideas concerning itVeiling the face $-A$ cowardly captain-March and its fickleness

\section{CHAPTER XVIII.}

\section{$\operatorname{KEOS}(Z \mathrm{EA})$.}

Harbour-Connection with the world-Barba Manthos-Interview with the Custom House officer-The acorn trade-Oaks in Keos - Koressia - The good road-The Chora of Keos and its vicwOur quarters-Curious aspect of town-The lion of Keos-Outlying hamlets-The farmer's bundle-Ceremony on September I -Granaries in the ground-St. Anarguris and the sacrifice on July I-Expedition to Karthaia-The mist_Cliffs and Nereids-Food placed for them-St. Artemidos and children-The oak cureThe position of Karthaia-The remains-Keote wine-Ruins of 
ancient villages-Expedition to Poiessa-Convent and tower of Hagia Marina-King Otho's depredation-Description of tower -An interesting old man-Ghost of Manetas-The evil eyeWhitewash crosses-Valley of Karadra-The ruins of IoulisThrift of Keotes-Convulsions of nature-The miltos mines and harbour of Otzia-Adieu to Keos . . . . . .

Note on the Ruins of Four Ancient Cities of Keos: I. Koressia -2. Ioulis-3. Karthaia-4. Poiessa . . . .

\section{CHAPTER XIX.}

AMORGOS.

\section{During Easter Week.}

Remoteness-The Easter feast-The steamer dangerous to old customs - The lower town-Climb to the upper-Big rock-View orer island-Offerings in the church-Costume-The tourlos-The café — Nad Spiro-The demarch-Papa Demetrios-Good FridaySt. Lazarus' song--The convent of Chozobiotissa-Extraordinary position-Danger from roclis-The silver eikons-Their appearance-Easter morning-Meeting the eikons-Conveying them to the town-Monday's expedition up Mount Elias-Visit to St. George Balsamitis-The prophetic source-When popular-The church of the oracle-Papa Anatolios opens the oracle for meTells me my fate, and expounds the theory by which he regulates his answers-The origin of the oracle-The eilions and the procession come-Kera Maria's incantations-The eikons at the harbour-Papa Manoulas' house-Blessing the ships-Easter Sunday-Farewell to the eikons-The dance . . . .

\section{Through the Island.}

Papa Demetrios' house and treasures-'God empties His bowl'-Old towers-Aigiale and the Roman remains-Tholaria-A love potion-Ny failure-Vigla and the remains-Strymbo-Langada - Rope walks - The fortified refuge-Wine in skins-A riddleMountain village-Ruins of Minoa-A quaint farmhouse and its contents-Gialou-Arkesini-Papa Demetrios' father-The ruins - The Madonna of Kastriani-Brytzi and its hospitality-The ancient tower-A distillery-An inscription-Olive-presses . 


\section{THE CYCLADES.}

\section{CHAPTER I.}

SERIPHOS.

Ereryone landing at Seriphos must naturally think of those frogs which Pliny tells us were always silent here, and it was a disappointment to me when I heard them croaking gaily on the little plain down by the harbour. I confess I believe that the saying about the frogs of Seriphos being silent referred to the boorishness of the inhabitants when they visited Athens.

Captain Georgios Hadgi Nikolas Ibelligeka, into whose hands we fell on landing, was anything but a silent member of society, and before many days were out we had cause to regret his loquacity. Captain George we called him for short-the rest of his name was so very long.

The rocks were the second thing we looked at at Seriphos, and as we did so we thought of Danaë and Perseus landing here in a chest, and being received by King Polydectes with all hospitality; here Perseus left Danaë, and when after a successful voyage he returned with Medusa's head, and found King Polydectes making love to Danaë, he forthwith turned him and all the Seriphiotes into stones. This story when you look at the landscape seems natural enough, for Seriphos is an island with lovely out- 
lines; the town is built on a conical, escarped hill, just above the harbour, with caves and rocks all over it, just as the inhabitants were standing when Perseus petrified them. Modern white houses are now clinging like mussels to these rocks, and the summit is crowned with the remains of a medireval castle. Some peasants brought us some old coins with Medusa's head on-the old coins of Seriphos, in fact-and with the usual sharp-wittedness of their race they told us that they were the coins of the first queen of Seriphos, who lived up at yonder castle.

The village of Livadhi, by the harbour, is small but tidy, and we there partook of refreshments in a clean fisherman's cottage off a table rudely carved with all sorts of fish designs. The ceilings of the houses are here all made of canes placed crosswise; on the top of this ceiling they put seaweed, and on the top of the seaweed mud, which is carefully pressed and rolled, and forms the roof of the one-storeyed houses ; a very treacherous roof, indeed, in wet weather, as we often experienced.

The tiny plain down by the harbour is a pattern of fertility. There is a well in each field; pomegranates, figs, and almond trees abound ; another feature peculiar to Seriphos at once caught the eye : every proprietor has his grave in his own field, built like a little shrine, and if he sells his field special provision in the articles of sale have to be made for the non-disturbance of ancestral bones. This custom is not carried on in any other of the Cyclades, and reminded us of the days when an Athenian possessor of land left directions in his will to be buried in his private ground (Demosthenes, 'Euerg.' p. I I 59). Frequently, too, the graves, as at Seriphos now, were by the roadside. The family sepulchre of Isocrates was near the Cynosarges, that of Thucydides by the Melitic Gate. We climbed up the steep ascent to the town on foot, 
as did the rest of the population who had come to see the steamer arrive: women carrying their babies tied to their backs with string; fishermen with their baskets full of fish, now in great request, for the ante-Christmas fast had just set in ; and by our side our new host, Captain George, trotted, pointing out each object of interest we passed. "This is the tomb of So-and-so, who died of soand-so, and was the father of Maria So-and-so. This is the Church of St. Isidoros, where is a spring of warm water, reckoned excellent for the health, where a yearly panegyris (a festival) is held; and it was built by Sophia Nakri, who was asleep and dreamt she was caught by her neck by St. Isidoros and commanded to go and build a church on this spot. When she awoke she had it built. Come in and have a glass of water; there is iron in it.' So Captain George rambled on. I followed him in, drank some exquisite water, and recognised why it was dedicated to St. Isidoros, because $\sigma i \delta \eta \rho o s$, iron (according to modern pronunciation) suggested one of those ecclesiastical puns in which the Eastern Church loves to indulge.

Captain George here paused awhile to rest, and as I scrutinised our new acquaintance I felt I did not like him; he was a little thick-set man with an evil countenance, but sparkling with intelligence. Afterwards I learnt that he was well known in these seas as an expert smuggler, who would have been a pirate if he had lived fifty years ago. He had just got a nice new caïque painted green, and his plan was to offer us hospitality and to persuade us to take his boat at a price which would pay him better than smuggling.

We went on a little further.

'Here is the Church of St. Tryphon,' said Captain George, 'the protector of agriculture.' Not knowing 
much about St. Tryphon I questioned further, and found that he is in great repute here. On his day no one works or cleans out his house, because they think he has power over rats and all animals hurtful to agriculture, and on St. Tryphon's Day the Church has offices and prayers for the special supplication of this saint to ward off blight. St. Tryphon must, I thought, be a descendant of Apollo Smintheus, who was worshipped in the neighbouring isle of Keos.

Captain George's house was a new one, at the lower end of the town, really quite a mansion for the islands. You enter the one sitting room with the divan, and off this are several little boxes, about eight feet square, entered by gates four feet high, the upper part being open : these are bedrooms. Ours had a thin gauze blind across the opening, which afforded us only a sorry attempt at seclusion.

Captain George's wife was a chattel, and a very uninteresting piece of furniture, too; for he hounded the poor thing about until she looked like a scared mongrel. She waited upon us at meals and never took a part in them. She cooked, she swept, and she slaved whilst the captain made merry with his guests. The wife of a lower class Greek is a pitiable object, much as she was in Hesiod's time, who, in his 'Works and Days,' shows us a wife's condition then, and considered it the worst possible feature of a bad wife to wish to sit at meals with her lord and master. Hesiod's advice to a young man starting in life would apply to a Greek of to-day: 'You must start with a house, a wife, an ox, and a plough.' Mrs. Ibelligeka would come up to Hesiod's standard.

After the usual slight refreshments of coffee, jam, and mastic, we were joined by the demarch, a priest, and a schoolmaster, and taken forth to see the town. Of all 
towns in the Greek Islands, Seriphos will remain fixed in my mind as the most filthy. The main street is a sewer into which all the offal is thrown; and it is tenanted by countless pigs - for each householder has liberty to keep three. What the nuisance must have been when the number was unlimited I cannot think. Furthermore this street is like a ladder of rocks, and the pigs in their movements are as nimble as goats, most dangerous to the peace of mind of the pedestrian. Sometimes the street is not two feet wide, sometimes it is expanded to six feet, but always an inch deep in mire, often more.

In one of these narrow streets on the Tuesday after Easter the maidens of Seriphos play their favourite game

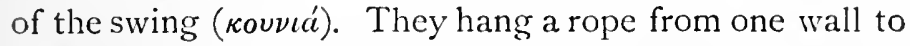
the other, put some clothes on it, and swing, singing and swinging, one after the other. Aware of this the young men try to pass by, and are called upon for a toll of one penny each, a song, and a swing. The words they generally use are as follows:- ' The gold is swung, the silver is swung, and swung, too, is my love with the golden hair;' to which the maiden replies, 'Who is it that swings me that I may gild him with my favour, that I may work him a fez all covered with pearls?' Then, haring paid his penny, he is permitted to pass, and another comes on and does likewise.

The houses opening on to this street were mere blachholes, where sat families shivering round charcoal fires on which pots full of ling were boiling for the evening meal. They seemed hospitably inclined towards us, for one woman ran out with a branch of myrtle and some basil, which she handed me for good luck; rather a nuisance, indeed, for the ascent demanded all one's care. The summit of the hill, and the castle crowning it, were at length reached, and here the schoolmaster showed us 
a niche in which, he said, once stood a statue of a king of Seriphos, which the English had taken away. I asked for further particulars about this, to me, unknown royal house of Seriphos, but the schoolmaster's genius for invention would lead him no further. He had not the face to tell me that it was a statue of King Polydectes. Over the gateway to the castle was a coat of arms, and I 433 over it ; so I felt convinced that the schoolmaster alluded to a statue of one of the Latin dukes who ruled in Seriphos. But, though the English have been great robbers in Greece in their day, I question if anyone ever burdened himself with the statue of a Crispi or a Sommaripa.

The Church of St. Athanasius was worth seeing, being round with two little apses. It has a lovely iconostasis, commonly called tempelon, or screen, before the sanctuary, carved in wood, with vine tendrils, and festoons, and niches for twenty eikons, or sacred pictures, along the top. The rock on which the town is built goes down straight on the northern side, and is covered with a greenish lichen, which contrasts curiously with the white houses wedged against it.

The antiquities left in Seriphos do not point to any very great artistic merit in the days of old; a few headless statues here and there, fragments of pillars, and one solitary sculpture of a symposium over a doorway were all the traces that we could see of the city where once dwelt the 'silent frogs.'

Next morning we started on an expedition with the object of visiting a convent dedicated to the Archangel Michael and a remote village called Galene (peace): Captain George was to be our guide. He had nothing to do, he said, and if we would pay for a mule for him nothing would give him greater pleasure than to do the honours of his island. There is much that is pretty in the steep slopes of Seriphos, though the island, except 
near the town, is bare; for at this time of year the vineyards were brown, and the long, straggling vines, which in the islands are trained along the ground to get what protection they can from the summer winds, do not in winter present a very lovely appearance. Seriphos is noted for its wine, and it is one of the chief industries of the place. Each vineyard has its wine-press in it ( which the juice of the grapes when trampled on flows into a lower tank; all round were thrown the remnants of stalks and skins from the late vintage and the hard matter which had becn cxtracted from the compressed pulp.

Aftcr extracting the juice in this manner they boil it for a month before it is considered fit to drink; and the day of St. Minas, in November, is considered as the proper one on which to stop boiling the wine ( $\left.\dot{a} \pi a \beta \rho a \zeta^{\zeta} \omega\right)$; and on this day all the well-known winc-tasters of the place repair to the vats and expect a present of wine straight out of them as an incentive to approve.

In July, when the firstfruits of the vintage are supposed to be ready, they throw a bunch of grapes into their houses, thinking thereby to rid them of rats and other vermin, saying, as they do so, 'The black grape will sicken, the black grape will poison. Out with you, fleas and rats!' And on August 6, when the vintage begins, the Church has special offices and prayers for the success of the same.

In connection with the planting of vineyards they have quite a Bacchic festival in Seriphos. On one of the many feast-days of the Virgin after matins are over the man who desires to plant a new vineyard calls together fifty or more men, according to the size of the field which he intends to plant. To each man he hands a spade, and then he fills skins with wine, and has joints of goat's 
flesh, which have been roasted for the occasion, brought out, and the company start off in high glee, singing as they go and preceded by a standard-bearer holding a white banner. During their interval of rest they consume the goats and the wine, and then work till the vineyard is planted - for it must all be done in one dayand in the evening they return home, with their spacles, their hoes, and the wine-skins empty, somewhat the merrier for having imbibed the contents. At a spot called Panagia, before the Virgin's Church, the white standard is set up, and the Seriphiotes enjoy a dance that evening in which the vineyard-planters join.

A somewhat similar co-operation is customary in Seriphos when the first rains of October fall. All the husbandmen meet together to assist one another at the forges in preparing their implements of husbandry for the coming season. They come with their spades, their ploughs, and their mattocks, and they come prepared, too, to have a festive gathering; and every evening until the work is done they have drinking parties, regular

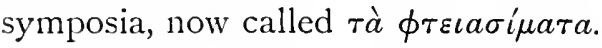

Another custom connected with husbandry still in vogue in Seriphos is that on September I4, the Day of the Cross. Farmers take a little of the grain which is about shortly to be sown and a rose with them to church. These things are blessed in the liturgy. The rose is broken up and scattered about in the first field which is sown that year as a sure emblem of abundance and success. This is a trace of the ancient $\pi \rho o \eta \rho o ́ \sigma \iota a l$, or sacrifices before the sowing of seed, to ensure a productive harvest.

Captain George was most communicative about the ways of his country, as were also the muletcers who accompanied us, and supplied any knowledge in which 
Captain George was wanting. One of them, a stalwart fellow with grizzled hair, suddenly put me a question which puzzled me not a little.

'Did you ever hear of the transfiguration basket, sir?'

The man was difficult to understand, the Seriphiote dialect being full of obscure words; and not until Captain George had come to my assistance did I comprehend what was meant. And he put it as follows into intelligible Greek for my benefit.

'On the day of our Saviour's transfiguration all faithful Seriphiotes believe that a basket is let down from heaven, full of all manner of good things, for the man who is lucky enough to be the first to see it ; but he must be very quick in asking for what he wants, for the basket is immediately drawn up again, and the gift is not forthcoming.'

As a confirmation of this story, the muleteer went on to relate how a shepherd had once seen this basliet descending, and, thinking hurriedly in his mind that money would be the best thing to have, he cried out in all haste, 'Two thousand ( $\chi^{\prime} i \iota \iota$ ),' and was going to add florins, when two jars, called here $\chi \varepsilon \hat{\imath} \lambda \iota a$, from $\chi \varepsilon \hat{\imath} \lambda{ }^{\prime} o s$, a brim, fell from the basket at his fect.

This story ought to be a warning to the Greeks generally to alter their pronunciation; for when nearly all the vowels and diphthongs are pronounced like $e$, that is to say, $\iota, \eta, \varepsilon \iota, o \iota, v$, other people are puzzled who are less hurried visitors than the heavenly basket.

By this time we were nearing the convent of the archangel. From a distance it looked like a fortress; around it is a high wall with battlements, and a terrace inside, from which in those old troublous times the monks could fight. Beneath the terrace are the cells, and in the centre of the square is the church. There are four towers 
at each end of the walls, one of which is now converted into a dovecote. The entrance is exceedingly low, only. about four feet high, at the top of a flight of steps, which have been added since the days of pirates. Formerly it was approached only by a wooden staircase, which could be drawn up. In the door is a most extraordinary bolt and wooden key, being a long bit of jagged wood, which is shoved into the bolt, and fits itself with a jerk into the required place; but it requires practice to work these locks. The ceiling of the porch was all crisscross reedwork, like the houses, and from it were hung the scales, with which they weighed the produce of the fields let out to husbandmen.

The church is old and interesting, being round and vaulted, evidently much earlier than the date over the door, I 447, which was of marble, and with rudely carved grape tendrils, with leaves painted green, stalks painted brown, and the background yellow, climbing up the jambs, above which were two birds on two poplars and an inscription describing the might of the archangel.

Inside the church was beautifully frescoed, having round it a frieze of saints, full length, over a dado of drapery. The vaulted roof was covered with biblical scenes, and on the entrance wall was the usual terrible fresco of St. Michael, and on the left those awful representations of hell so common in Byzantine churches. There is the fiery river with its inscription on a scroll (o múpı'os тотано's) ; kings, bishops, \&c. are engulfed in a dragon's

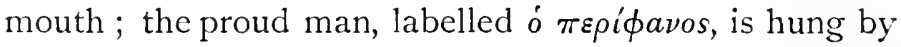

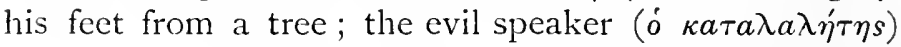
is dragged by his feet, whilst a demon follows him, shoving a spear down his throat; the glutton is being slapped by two demons at the same time on the stomach and on the mouth; the drunkard is head downwards to 
let the wine run out ; those who cannot get up for early mass on Sundays are lying in bed like dead men, with elegant coverlets over them; and the tortures of the woman who has nourished a foreigner are horrible to behold: a fitting subject for contemplation in these islands, from whence the female population has gone, at one time or another, to the Turkish towns as servants or to fill the harems.

The poor old monk who accompanied us was in a great state of grief that his superior was absent; however we satisfied him by promising to look in again on our return from Galene. He was such a queer old wretch, with bare legs, baggy blue trousers, blue cotton jacket lined with filthy fur, and a black cap on his head, by which alone we knew him to be a monk. His poor head was all on one side, and surrounded by a large crop of unkempt grizzled hair. Most of these monks are little above peasants ; they go into the monasteries, instead of the workhouse, when too old and infirm to work, and take a vow to observe celibacy and let their hair grow. In Greece, as with us, the proverb is common, "When the devil grows old he becomes a monk.' They till the ground belonging to the monastery and do all the menial offices, carrying out thereby the advice of an Egyptian father who taught that a labouring monk was tempted but by one devil, whilst an idle one was exposed to the devastation of a legion.

The village of Galene was about a mile from the convent, in a valley to the north of Seriphos. From above it looked like a giant's staircase, one house below the other. There is iron in the soil about here, and the roofs, made of mud, have tinged the houses with a bright and picturesque yellow from the iron that is in it. Few places in the world can be more out of the world than this; we 
literally scrambled down a precipitous path, which formed the street, and went to the demarch's house, an old man, eighty-five years of age, by name Kousoupis. He greeted us warmly, and said he had had a presentiment (ópa $\mu$ ) the previous day that strangers would come, so he had ordered his daughter to bake more bread. We saw at a glance that we were launched into a thoroughly oldworld, superstitious family, and acted accordingly.

Old Kousoupis, however, in his day had seen something of the world; he had fought in his country's wars, and had been present when Otho arrived as the first king of the Hellenes. Nevertheless he remained what he was born, an uncultured, intensely superstitious Greek. 'I have presentiments,' said he, 'for everything that will happen. Before I was elected demarch I had a presentiment; before my wife died, twelve years ago, I was helping a shipwrecked crew down in the harbour of Sicanna, and I saw a vision; and though the captain of the ship begged me to remain to protect him from pirates, being a man of influence, yet I felt obliged to come home on account of my vision; and then I found my poor wife about to deliver up her soul, which she did almost immediately afterwards in my arms.'

'Do you believe in the existence of Nereids?' I mildly asked. And forthwith the tongues of the whole family were loosed.

Now much has been written about the Nereids of modern Greece. Various stories from various parts of modern Hellas have been produced, which give us a varied idea of the belief in these mysterious beings. First we have the Nereids of the streams, and the Nereids, properly so called, are water witches ( $\nu \varepsilon \rho \grave{o}, \nu \varepsilon \rho \varepsilon \hat{v} s$ ), and they correspond to the water nymphs of antiquity. Wherever there is a warm healing stream they believe that it flows from 
the breasts of the Nereids. But he that wishes to be cured, must go holding a green lamp to fill his jar, and must leave a bit of his dress there, and must hurry away without looking back, otherwise he will lose his senses. When these waters are troubled they say the Nereids have been bathing, and woe to the man who is unlucky enough to see them; they revenge themselves on him for his impertinent beholding. Then we have the Nereids of the woods, valleys, cliffs, \&c. ; the Dryads and Hamadryads of antiquity. We hear of them with goats' and asses' feet, some resembling the Satyrs, others the Harpies of antiquity. On their heads they wear flowing scarves, like the old-fashioned costumes still preserved in some of the islands. They are supposed to rush in a whirlwind through the air, they injure children, they dance to the tune of the lyre played by some wretched man whom they have smitten, and by their beauty they attract men to their peril ( $\nu \nu \mu \phi o \lambda \eta \pi_{\tau}$ sos). Sometimes by getting their wings or their handkerchiefs a man may capture a Nereid with whom he is smitten; but first she will turn into all sorts of forms; a snake, fire, camels, \&c. like the old story of Peleus and Thetis; and he may have children by her-for instance, the great family of Mavro Michaelis of Manes are supposed to have Nereid blood in their veins. Much poetry is connected with the popular idea of the Nereids: their smiles turn into roses, their tears into pearls, they have lovely long hair. 'Beautiful as a Nereid' is a common term to express beauty. Their work is weaving, and they produce most exquisite things; as they work a man they have bewitched plays the lyre to them. Such are the Nereids of to-day.

Some of the tales about them which I heard in my travels I will relate, having the value of being identified as really existing. 
No sooner had we spoken of Nereids than the demarch's daughter, a woman of fifty or more, at once developed a desire to talk and tell her story as to what had happened to her as she was staying in Constantinople with a cousin of hers who had just had a lovely child, which had become ugly owing to the influence of the Nereids; so the mother was determined to take the child and lay it on a marble monument in St. George's Church. Having done this she laid it on a grave for a while and took Miss Kousoupis with her without telling her anything about it. The child was left for five minutes on the grave, and then the mother gave it to Miss Kousoupis to carry; and as they went away, owing to the mother having given Miss Kousoupis no notice of what she was doing, she looked round, and the child died in a fortnight, and she herself suffered from headache, giddiness, and general wasting, and was brought back to Seriphos in a dying state. So her mother took her to the monastery of the archangel, where we had just been, and there they lived for forty days until she recovered; but even now she said she was liable to fits of faintness and giddiness. Here in one story we have two ancient ideas combined: the baneful influence of the Nereids on the young, and the prevalent idea that illness can be cured by lying in churches. The vividness of the narration and the excitement of the narrator quite convinced me that she believed that what she was telling me was true.

Seeing we were interested in this subject, the demarch sent for an old woman popularly believed at Galene to be one hundred years old. Her sobriquet was Plyṇtes, for in her youthful days she had been employed in washing out the wine-vats after the process of treading the grapes was over. Such a wrinkled piece of goods I never saw. She had on a white cap drawn forwards over 
her eyes, so that only the nose and chin could be seen cn profile. Over this was a shawl tied round her chin; she had on a snuff-coloured short petticoat, stockings to match, a fur jacket, and over it a wide coat of brown Dutch carpet. She hobbled in, and seemed terrified of us, crossing herself lest we should cast on her the evil eye. She would not speak a word at first, in spite of the demarch's assurances that our intentions were peaceable. She almost shrieked when he spoke about Nereids, started up, and prepared to hobble away, but was persuaded to return. Again when the question was put she asserted, 'I know nothing,' shut her eyes, and groaned, and then, turning to our, by no means juvenile, host, she murmured, 'My little boy, what are they going to do to me?' Thereupon everyone set to work to console her and stroke her, assuring her that the English meant no harm; so she at length told her tale in a low voice, which had to be translated to me from the dialect.

'Years ago Michael Kappazacharias was digging in his vineyard near St. Cyprian's Church.' Here she grew frightened again, and crossed herself violently before continuing, "Well, it was a very calm, still day, when suddenly a whirlwind came and carried him to some distance; and as he was being borne along he felt the firm grip of the Nereids. Shortly afterwards he was found lying senseless, and carried in that state to the village.' In this story we had the Nereids of the storm, like the Harpies of old, who carried off the daughter of Pandareos from the halls of Olympus in a rushing wind, such a wind as Penelope longed for to carry her away to get relief from the troubles which surrounded her.

On our climb up the village the demarch made us pay a visit to his brother-in-law, Stavris by name, and ather of the superior of the archangel's convent. He 
was in bed wrapped up in very rough blankets, and a coat over his shoulders of a brown carpet material. He was delighted to see us, and apologised for being in bed, saying that he was not ill, but having walked about for ninety years his feet hurt him, and he suffered from the cold. There was another bed in the room, reaching from side to side, like the berth of a ship, with a curtain aeross it tied back with a ribbon, where several generations of his descendants slept.

More stories of Nereids were here forthcoming, the demarch being determined that Galene should for ever be associated in our minds with those mysterious beings. Old Stavris told us how he and a well-to-do man belonging to Seriphos were once sleeping for the night in a cowshed, being benighted on their way. During the night old Stavris awoke, and saw men approaching with great horns on their heads, both of whom he knew to be dead. One of them said, 'Stavris, if you had not been here we should have run the rich man through with our horns.' In spite of their asseverations to the contrary, I had not the least doubt in my mind that some vagabonds had come to steal the cattle or rob the rich man; for similar stories of this means used by pirates to terrify weakminded peasants are common enough in the islands.

We called at the archangel's convent again on our way home, where the superior was prepared to receive us in the guest room and to regale us with coffee and jam. He showed us all the old eonvent books, which were being rapidly consumed by damp and worms, and then took us to see the church again under his own guidance, telling us the history of various gifts to the Church-lamps, eikons, \&c.

The story of two hanging lamps interested us. He said they had been given by a sea captain in fulfilment of 
the following vow. Two sailors from his ship had stolen two lamps from this church, and then embarked with them on their return journey; but when the ship had got a little way from Seriphos it refused to move, though the wind was fair and the sails unfurled. At length a pigeon came and perched on the top of the mast, which the captain tried to shoot, but he could not. A sailor then climbed the mast to see if he could catch the bird, but it plucked out his eye. So the captain was awestruck, and said, 'What wrong is this on my ship?' and the two guilty sailors in terror confessed their theft. ' Throw out the lamps,' said the captain, 'and I vow to give two new ones to the archangel;' whereupon the ship sailed on her course. Twelve months afterwards, at the festival of the archangel, he returned with the lamps.

'What do you think would have happened to him if he had forgotten his vow ?' I asked hesitatingly. 'Well, sir,' he replied, 'to prove to you that the archangel makes a man keep his vow, I will tell you the story of a man of Galene who was ill, and promised an ox to the convent if he recovered. The man got better, but forgot to keep his vow. One day he was returning from his work, and found himself surrounded by a lake, so that he could go neither backwards nor forwards ; and in his distress he cried, " $\mathrm{O}$ my archangel! if you will remove this lake from around me I will give you two oxen.' And sure enough next day he knocked at the convent door with the two promised oxen.'

Surely it is hardly to be wondered at that the people continue their belief in the supernatural if their religious instructors preach to them in this fashion.

Our journey home was a pleasant one. We passed through another village called Kalosis, when all the inhabitants came out to see us, and pressed us to reccive 
hospitality in their houses; but as evening was coming on we politely refused, so they satisfied their hospitable appetite by bursting our pockets with presents of oranges, melons, and nuts, and by giving us bouquets of flowers, which rather embarrassed us on muleback.

During our absence the captain's wife had prepared us an excellent repast-macaroni and cheese enough to feed a regiment, a tender fowl (for a wonder!), and a salad dressed to perfection.

That night a fearful thunderstorm made of the main street of Seriphos a perfect mud cascade; the plain below was the receptacle of all this excellent manure. No wonder it is green and fertile.

After the rain had ceased we set off for another point on the island, and on our way visited the long line of windmills which stretches up the hillside behind the town. Two of these are draught mills, circular ones, with an upper storey without a roof. There are two openings, one to the north, another to the south, and inside are six flaps, which catch the wind and turn this upper storey round and round, and in so doing the corn in the lower storey is ground. These draught mills are much thought of in this windy isle, and reckoned superior to, though not so picturesque as, those with sails. Pursuing our course, we next climbed to a spot where there is a long ancient inscription cut on the smooth rock, very difficult of access, and which was only discovered by a peasant last year. It is in large badly formed letters as follows :-

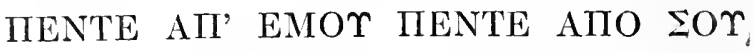

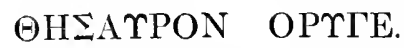

What can this mean, 'Five from me, five from you, dig up a treasure'? Does it refer to the mines of Seriphos, and a co-operation for the purpose of working 
them; or was it written by one of those Roman exiles who were sent to die in Seriphos-Cassius Severus, the orator, for instance, who Tacitus tells us 'grew old on the rock of Seriphos' (saxo Seriphio consenuit)?

The view from this spot is grand and extraordinary: the town was below us, the plain still lower, and the island-dotted sea stretched around us. Just outside the harbour is Seriphos' Chicken (Serphopoulo), a barren rock, where in summer time herdsmen take their flocks; beyond is Siphnos, our next goal.

After trudging on for about a mile beyond this inscription we were shown a magnet mine, where the earth sticks to the point of your knife. Could this be the treasure to which the inscription alludes? I think so. There are a few traces of ancient buildings near this spot-a few broken bits of columns and a white marble lion stuck as an ornament at the top of a low mud-roofed church.

From here to the white watch tower, on the southwest of Seriphos, is a considerable ride, and, except from an archæological point of view, not a repaying one. There is a good harbour close to this tower, still called by its Italian name Porto Catena, for in Italian days there was a chain across the mouth to protect the ships inside, like the one they had at Pisa; and from here ships still fetch iron from the mines. As we went our muleteer sang us the song of the white tower, which tells its modern legend - how the Turks laid siege to it for twelve years, and how at length an old woman was persuaded to show them the source of water which kept the garrison alive; after this it was taken. It is a pretty quaint ballad - the modern Grecks have all their old war legends in verse like this, and thus hand them down as traditions from father to son, just as their ancestors did in the days of Homer. 
As for the ruin itself it is one of those numerous round Hellenic towers of white marble, about thirty feet in diameter. Evidently in ancient times they got iron from here, and this tower was built to protect the ships.

It was not until we wished to leave Seriphos that we really began to dislike Captain George. It was a wet morning, but cleared up about midday, so we got ready to start, and were greeted as usual by intimations that night was coming on. We were firm, however, and at last got ourselves and our traps conveyed to the harbour, Captain George having previously told us that his boat was ready; but it was not, the canvas bulwarks were not even nailed on. His eloquence now took the form of inventing one futile excuse after another; there was no oil, no bread for the men, and these things must be fetched from the town. Everyone, of course, took his side, and we, poor foreigners, had to exercise all our firmness. We told him to dance on his plate, an expression in vogue for quickness. We positively refused to enter the house they proposed that we should spend the night in. Three whole hours we consumed thus idly, and at last, at four o'clock, when it was really getting late. Captain George reluctantly consented to start; and as we sailed off for our journey of eight miles with a favourable wind we heard ominous whispers of winter, night, dark, Boreas, calm, whirlwind, and all the terrors that could be invented.

Until we were close upon Siphnos the wind was favourable; and, oh! if we had but started an hour earlier all would have been right; as it was, a persistent calm set in, and Siphnos, like St. Brandon's Isle, hovered for weary dark hours, now before us, now behind us, as we tacked and struggled for a breath of wind. 


\section{CHAPTER II.}

SIPHNOS.

St. BRAnDon's ISLE was reached at last, and with the aid of oars and a fitfully flapping sail we entered the little harbour of Cherònesos shortly after midnight. Captain George took an infinite pleasure in teasing us just now. 'Rascally men here,' he said ; ' those spongefishers will cut our throats and be off before morning;' and as we glided on we passed several sponge-fishing boats from Hydra done up for the night. They had made a tent with their sail across their trident $(\kappa a ́ \mu a \xi)$ and were sleeping under it. This trident is for loosening and hooking up the sponges, and has in this case eleven prongs-not three, but still it has the old word $\kappa a \mu a \xi$ attached to it.' Sometimes a $\kappa a ́ \mu a \xi$ has only five prongs, with hooks at the ends, with which to loosen the sponges. One of the boatmen struck a light as we passed, and revealed the interior of their improvised cabin.

There are only three inhabited houses in this remote little bay to the extreme north of Siphnos: two of these were shut for the winter, and the third, inhabited by an old potter and his wife, opened its door to us, such as it was. The house consisted of one room, with the potter's

${ }^{1} \mathrm{Ka} \mu \alpha \boldsymbol{\xi}$ in $\mathrm{Il}$. xviii. 563 is used as a vine pole; Eschylus, $A g .66$, as the shaft of a spear; Luc., Navig., as the tiller of a rudder. It is con. nected with $\dot{\alpha} \mu \dot{\alpha} \sigma \sigma \omega$, to brandish. 
wheel in the middle, and around were all the results of his last day's labour waiting to be baked on the morrow; a seat built into the wall, a low table, a gourd or two, cheese baskets, and a bed in a corner formed all the potter's household gods.

From this bed the potter and his wife had just risen: it was formed by some boards fixed into the wall on two sides and supported at the outer angle by the rough trunk of a tree, with one branch left as a step to help you climb the four feet that it was raised from the ground. Some hard woollen sheets and a hairy rug, or ' chlamys,' of home-spun material formed all the covering for these boards; and on to this the potter and his wife insisted that we should mount. They would take no refusal, poor hospitable old things, so we passed the remainder of the night there as best we could, whilst our host and hostess, Captain George, and our sailors lay stretched on the mud floor around us ready, as the captain grimly remarked before he went to sleep, to protect us and our baggage from the sponge-fishers if they should attack us in the night.

In the night a tremendous storm arose, which burst open the door. For a moment we thought our enemies had come, but were relieved to find that only the rain and wind came in ; we were thankful, too, that we had insisted on leaving Seriphos when we did-such a storm as this might last for days.

We liked our old potter very much on further acquaintance: the woman did all she could for us next morning, and, like the demarch of Galene, she said she had been expecting guests, for her eye had been itching all the previous day. The potters of Siphnos are celebrated throughout Greece. In the spring time they start on their travels far and wide, and settle in towns and 
villages for days and wecks until the place is supplied with large well-made earthenware amphore and cooking utensils; and it is an ancient art which has never left the island. In Pliny's time and before that the Siphniote keramic art was celebrated, and some specimens found lately at the bottom of the sea off Cape Kalymnia, to the south of the island, prove that jars of excellent workmanship of the best period of Greek art were manufactured here; and these were probably lost when being exported.

The old potter worked for us at his wheel. There was the disc $(\tau \rho \circ \chi i \grave{a})$ which he turned by the application of his foot ; this was joined by a spindle (

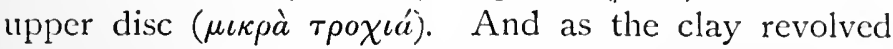
round it, it was fashioned into the form he wished by a wooden lathe which he held in his hand. He reminded me strongly of a potter at work as represented on a certain vase in the British Museum.

We had to wait some hours before mules could be fetched, and the old couple tried to prepare us a meal, which consisted of fish soup and onions, for onions, as appears from a proverb in these parts, are common enough in Siphnos. 'Give a Siphniote an onion' corresponds to 'carrying coals to Newcastle.' And as we sat around the low table the potter told us some of his family troubles: how two of his sons had been burnt in a firc at Constantinople, and how all his daughters had gone to the mainland as cooks; for Siphnos has another speciality besides pots, namely, cooks, and in the Greek restaurants at Constantinople all the chefs are Siphniotes.

By daylight the neighbourhood of the potter's house looked dreary enough. It was but a stony, barren promontory swept by the northern blast, with a disused monastery, dedicated to St. George, at the end of it ; also 
the remains of an old Hellenic watch tower, turned into a shelter for cattle. Captain George went with us to the end of this promontory, and pointed out to us a dangerous rock just outside the harbour, and let us understand that if we had had any other captain but himself we should have found a watery grave last night.

'Bad sailors, these Siphniotes ; wretched island!' he muttered, and the insular jealousy at once showed itself. 'Look at all these stones,' he continued; 'they are full of vipers, and in summer people have to wear shoes and gaiters on purpose to protect themselves: we have nothing of this kind in Seriphos.'

I could not help rejoining that, at all events, they had plenty of stones, and thought to myself they probably had plenty of vipers, whereas they have nothing to boast of like the fertility of Southern Siphnos. Captain George was a thorough Greek, such an one as Pallas Athene would have admired, like Ulysses, for his cunning. Having driven as good a bargain with us as he could, we overheard him arranging with the old potter for the export of pots on his return journey.

About midday our mules arrived, and we set forth on our way to the centre of Siphniote life, which lies to the south-west of the island, where it always was. Our road led through the bed of a mountain torrent, with laurel roses waving on either side; and when we had crossed the ridge of central hills we saw the long line of villages, five in all, which runs for nearly two miles along the western slopes. As each house has its own garden and olive orchard, and as green fields cover all the hillside, it was by far the most luxurious sight we had as yet seen in the Cyclades. I could not help remarking this to Captain George, who still accompanied us, and who shrugged his shoulders as he replied, 'Yes, the Siphniotes have advan- 
tages that we have not in Seriphos; a wonder they do not make more use of them.'

The Siphniotes are wonderful hands at whitewash. Every house, every church is covered with it. Ancient bits of statues and inscriptions, which have been let into the walls by way of ornament, are coated and illegible with it; a clean housewife picks out the edges of her stone floor with whitewash once a week, when she does her cleaning, and if the effect is monotonous it is at any rate clean; and the villages of Siphnos, if it were not for the quantity of coarse-looking pigs with short bristles which swarm in them, would be bright and pleasant enough. But these pigs are abominable creatures; they saunter in and out of houses at will. The Siphniotes cut their bristles for sewing shoes and making brushes with; hence a pig with a strong crop of these ready to be shorn presents a particularly forbidding appearance. Captain George at once remarked our disgust at these animals, and laughed and propounded a local riddle.

'What sort of a chicken is that which they scrape and cut, and then the shoemaker uses his feathers in his art ?'-Answer: 'A pig.'

All this fertile strip of Siphnos is shut off from the north and west by a lofty, prettily indented range of mountains. Of course Prophet Elias is the name of the highest, with a church on the summit, a specimen of old Byzantine of the tenth century; another is St. Simeon, with another church. We passed through two of the villages without stopping, and then drew up at Apollonia, a village built on the site of an old temple of Apollo, the ruins of which were used to build the modern church dedicated to the Virgin. In this village is the scat of government in Siphnos, the barracks, and the demarcheion, and here we were introduced to another brave 
mariner, Captain Prokos by name, who was to be our host, and who had been in command of a merchant ship, and had seen much of the world. He was an exceedingly jovial man, and had a buxom wife and blooming daughters, who at once came forward to receive us and introduced us to our new quarters. The women were very demonstrative, and loved to mark their civility by stroking my wife, examining minutely her clothes, and calling her a doll $(\kappa \circ \hat{v} \kappa \lambda a)$. They expressed the greatest astonishment at our luggage, humble as it seemed to us, and likened it to that of monarchs. Their house was built on the same principle as Captain George's, having a square sitting room, and four cabins for bedrooms leading off it, which contained huge beds, but no room to dress in, and were well stocked with what the Greeks playfully call 'black-faced heifers all blood and skin'; but we had a glorious satin quilt and a valance of magnificent Greek lace to make up for the other discomforts.

The Siphniotes are industrious and well-to-do ; they have a fertile island, olives grow to any extent, and every Greek knows that 'an olive with a kernel gives a boot to a man.' They have mines, too, and though the richer inhabitants complain that the existence of mines makes labour and provisions dear yet there are two sides to this question. A French company has started mining operations at Kamara, a place so called from the vaulted chambers cut by ancient miners in the cliffs (Italian, camere) close to the sea. We visited them one day, and saw there an interesting cave with the inscrip-

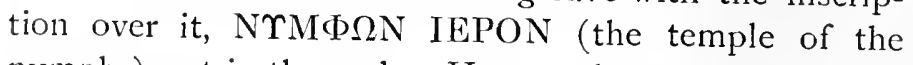
nymphs), cut in the rock. Here we have an old centre of nymph worship, and here we still find wonderful stories of Nereids and genii loci ( $\sigma \tau o \iota \chi \varepsilon \hat{i} a)$ associated with the spot. Travellers who cross a certain strcam 
close to here, more especially at midnight or midday, are exposed to the danger of being possessed ( $\nu v \mu \phi o-$ $\left.\lambda \eta \eta^{\prime} \pi \tau o s\right)$; and to cure such cases it is customary to prepare

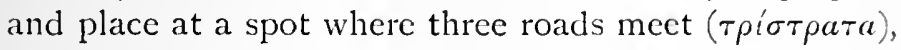
or hang in the wells, some bread wrapped up in a clean napkin, and some honey, milk, and eggs, to appease these nymphs. The genii loci, too, haunt certain wellknown trees and cliffs, and are like our old friends the Hamadryarls. Woodcutters fear to lie or sleep under a big old olive tree called Megdanos; and when they have to cut down a tree that they suppose to be possessed they are exceedingly careful when it falls to prostrate themselves humbly and in silence lest the spirit should chastise them as it escapes; and sometimes they put a stone on the trunk of the tree so as to prevent its egress.

At the wells we find another kind of sprite called by the peasants Arabs ('A $\rho a ́ \pi \eta \delta \varepsilon s$ ); and sometimes even piously inclined sprites haunt churches; these are rarely. evil-doing; if they are, they do not live in the church, but in a cave hard by, so as to prevent people from going there to worship. And not unfrequently we hear stories of the prowess of the patron saint-how he has driven them off and rendered the place safe again.

On our return journey we visited what was once a celebrated convent for nuns, dedicated to St. John the Theologian. Captain Prokos told us some sorry tales about the goings on of these ladies when he was young, for generally before they were placed in this convent they had been guilty of some misconduct at home ; and the Convent of St. John the Theologian before it was disestablished by the present Government was the favourite rendezvous of all the gallants of Siphnos. Captain Prokos lead us to infer that he had been there more than once, at which speech his wife administered 
a sharp reprimand, for she was not the down-trodden squaw our late hostess had become. Now these giddy nuns are scattered to the wind, and the tottering walls of their convent are inhabited by two very ancient females whose duty it is to clean the church and keep the lamps burning. The Siphniotes call it the Convent of Morкov amongst themselves. The name was curious, and excited my curiosity. A tradition, on which is based the origin of this name, says that a pious Siphniote built it years ago, and his wife objected to the money he had spent upon it ; whereat he replied, in French, ' $\mathcal{F}$ 'ai fait mon goitt,' and the name has stuck to it ever since. It is curious what a lot of western words have crept into the Siphniote dialect. Pigs they call francesi (Frenchmen) because a traveller of that nation exclaimed on hearing a pig grunt, 'Voilà une langue que je comprends!' The schoolmaster of Siphnos rejoices in the name of $\Gamma \kappa \iota \omega \nu$. 'Mine is a family of French origin,' he said ; 'the name was formerly spelt Jean.' Probably the mines had something to do with this and the family who ruled in Siphnos in the Venetian days, the Da Corogna, of Spanish extraction: this family provided princes for Siphnos for a century and a half, and then, in 1456 , the heiress of this family married one Nikolas Gozzadini, who became lord of Siphnos; not until $16 \mathrm{r} 7$ was the last of this family cast out by the Turks. There still live on the island of Santorin another branch of the Da Corogna family.

The Latin seat of government was at the town now called Kastro, an interesting specimen of mediæval fortification, built on a tongue of land running out into the sea, about half-an-hour's ride from Apollonia. And thither on the following morning our course was bent.

One is surprised at the quantity of churches spread about Siphnos, 'a proof of the piety of our ancestors,' 
said our muleteer. Two of these domed, whitewashed buildings lie close together, and have a peculiar interest of their own, inasmuch as they formed the lecture halls of the once celebrated 'School of Siphnos,' an establishment which will soon be blotted out of memory and forgotten; a generation hence none will remember what an important rôle this 'School of the Holy Tomb' played in the preservation of the Greek nationality during the dark ages.

It was founded by some refugees from Constantinople who fled to Siphnos for peace during the reign of the iconoclast Emperors of the East. On account of the seclusion of the spot and the difficulty of access it retained in all their simplicity the earliest customs of the Greek Church, purer even than the School of Mount Athos. Extensive grants of land and liberties were secured for it by pupils who in after-life gained distinction for themselves: amongst these were numbered patriarchs, archpriests, and bishops, who held sees at Cæsarea, Belgrade, Cyzicus, and elsewhere, many of whom returned to spend their last days in the island. and introduced the enlightenment of the world into their old school. The pupils lodged in the town and villages, and came daily, bringing their food with them, to attend lectures at these churches; and their minds were nurtured by men whose notoriety, if it has not extended far, is well attested to by contemporary writers. Nicholas Chrysogelos was headmaster of this school at the time of the outbreak of the war of independence. He forthwith initiated his scholars into the mysteries of the Friendly. Society, and when, on March 25, I82I, the banner of freedom was unfurled, Chrysogelos took those of his pupils who were fit to carry arms and joined the army in the Peloponnese. For some time he was Capo d'Istria's 
right-hand man in council and in war, and when he returned home after the final establishment of freedom he was made the first demarch of Siphnos, and died full of years and honour in 1857 .

Under the new régime the School of Siphnos had of necessity to be remodelled, for its work had been done. It had assisted in preserving the Greek language, religion, and customs from being obliterated during a period when they were assailed on all sides by Italians, by Albanians, and by Turks. And now the revenues of the School of the Holy Tomb have been appropriated to and form the nucleus of the modern gymnasium of Syra. We passed by the two churches just before reaching the Kastro; they will soon share the fate of many others of a like nature in ungrateful Greece-they will be ruined and forgotten.

The Kastro of Siphnos, or Seraglio, as it is still occasionally called, is a regular old-world Italian town, which has not been improved by the introduction of a few Greek customs. Each house has an outer staircase, which projects into the street for the benefit of the inhabitants of the upper storey; up this staircase climbs the chimney of the lower storey, and beneath it is the pigsty. The streets are narrow and dirty, many houses are falling into ruins, for the glory of Siphnos has left the Kastro, and is now centred in the villages on the hillside.

The ruins of an old town hall have an inscription in Gothic characters, testifying that it was built by one of the Da Corogna family in 1365 ; you pass on a step or two, and read an inscription, in ancient Greek, of course, let into the wall wrong way up by the ignorant builder; you go a little further, and see round a well a Turkish inscription, telling how it was erected by the munificence 
of the Ottoman dragoman. Thus from the stones by the street side can you read the varied history of the Kastro.

Some of the old houses are very fine: the one in which we lunched possessed a very large ante-room, with five doors leading off it, each with a marble fanlight carved like those we had seen at Tenos, three ships on either side, and a flower at the top; and the houses of the richer inhabitants of the place are perfect museums of Venetian treasures, glass, china, oak chests, cabinets, carved candle-brackets, pictures, and other things which delight the eye of a bric- $\dot{a}-b r a c$ hunter.

But the speciality of the Kastro is the female costume which is still worn by the elderly and by the poor, but, I fear, in a few years will exist no more. Of this costume the head-dress, or pina, as it is called, is the most striking feature: it is a tall erection, raised like a helmet. First of all they put on a sort of cap padded with cotton until it is somewhat like a miniature mule-saddle, and around this they twist the shawl ( $\left.\mu a \nu \delta v^{\prime} \lambda \iota \nu\right)$. On feast days the covering for this pina is most lovely, all sorts of gold embroideries being pinned on to it, butterflics, beetles, flowers, \&c. Two little curls peep out on the checks, and earrings of a most gorgeous nature are worn. We were shown one pair three inches long: on the top was a crown, below this a filigree representation of two eagles, and to this was hung an enamelled ship with twelve sails wonderfully executed in colours of white, green and blue enamel, and gold, and three large pearls below. We were shown, too, bracelets of fifteen chains formed of little rosettes, three inches wide and with an enamelled clasp. The dress of the pina costume is correspondingly magnificent, consisting of a skirt (fustana) of cloth of grold, a bodice (birikos) splendidly embroidered with 
gold and colours, and a green velvet overgown hanging

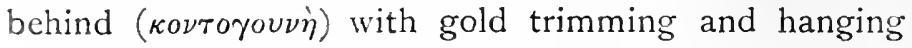
sleeves. Such costumes as these the ladies of Siphnos wore a century ago ; now only do they appear on a specially festive occasion, and most of them have fallen a prey to the hungry Jews who scavenge these islands for their bric-à-brac shops.

The castle of the Kastro is almost in ruins, and the Latin church, with pretty Rhodian plates let into the wall, is quite so, for there are no more Western Christians now in Siphnos. In fact, a new era has now dawned for these islands: the Western interregnum is over: a few names of people and places, a few ruins of Gothic art, a few costumes, and this is all that is left of the dukes of the Egean Sea.

Outside the gate of the Kastro, down by a little brook, are visible traces of a still more ancient régime. Four large sarcophagi, one of which is adorned with garlands of fruit, some remains of statues, some stones of buildings, point to the existence here of the old town called Siphnos alluded to by Herodotus. Traces of the old wall are still visible, and here, doubtless, was the

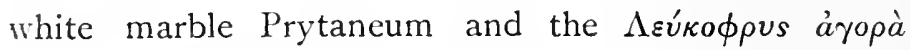
alluded to by the father of history. Three centuries ago there was to be seen, in a fair state of preservation, a temple of Pan close to the bed of this stream, in which was a statue of that deity, having in his mouth his beloved pipe, and gazing to heaven. The ruins of this temple were converted into a little church, and the spot is still called 'goat's foot' ( $\tau \rho a \gamma o ́ \pi o \delta \iota)$, from the statue of Pan, which has found a home elsewhere.

Siphnos in ancient days played no inconsiderable part in history; it was one of the richest of the islands, from its gold and silver mines. But once, says the 
legend, the Siphniotes, instead of sending gold to Delphi, sent only a gilded ball; so Apollo was wroth, and destroyed their mines by flooding them. We made an expedition thither, and easily recognised that they had been destroyed by the encroachment of the sea; but as these mines are important from an archæological point of view I will refer the reader to a special note thereon.

The great blow (Herodotus tells us) to the wealth of Siphnos was dealt by Samiote refugees who fled here from the rule of Polycrates, and demanded money from the wealthy inhabitants. On this being refused them, they plundered the place, took one hundred talents, and sailed off. The oracle at Delphi had prophesied this disaster, the wish very likely having been father to the prophecy, for Siphnos was generally unpopular; and the term $\sigma \iota \phi \nu \iota a \zeta_{\varepsilon \iota \nu}$ was coined to apply to any dishonesty: evidently the rich miners of Siphnos kept faith neither with gods nor men. Yet Siphnos had power even after this disaster, for we find her namc appearing on one of the rings of the three-headed serpent which was presented to the shrine at Delphi after the defeat of Xerxes, and in the rings of which were inscribed the names of the independent States which had sent assistance at this crisis. In every age an island rich in mincrals must hold its own ; and now, if the Siphniote mines were properly worked, it would rise again to be one of the most prominent islands of the Grecian Archipelago.

Our rest and our lunch at the Kastro were acceptable enough, for the day was hot and the room large and cool. An old man prepared us a capital meal of fish and light cakes, with honcy poured over, and told us much about the visit of King Otho and Queen Amalia to the Kastro; how he had attended upon their majesties; and how the queen had expressed her indignation 
at the tendency of the females to abandon their old costumes for Western tawdriness.

Our homeward route led us past two convents-one a nunnery with two women and several children left in charge of a grass-grown courtyard and crumbling walls, and the other the flourishing monastery 'of the well' $\left(\sigma \tau i \nu \nu \beta \nu \sigma^{\prime} \iota \nu\right.$, 'to the well,' as it is called). 'This monastery is buiit in a fertile gorge, and, as its name implies, amidst running waters and bubbling streams. This source supplies all Siphnos with water. And the luxuriance of orange and lemon trees, the festoons of maidenhair and other ferns, are quite fairylike as you ride along.

Sixteen monks are left at this monastery, and their reception room was most cheerful, for they had about a dozen guests-men, women, and children - with them, very different from the monastic seclusion of Western Europe. On the middle of the divan, crumpled up like a bundle of rugs, wrinkled and deaf, sat the mother of the superior. Her knees touched her chin and herheels rested on the edge of the divan. She was very gay and talkative nevertheless, and spoke of having been at Constantinople during the Crimean War, and praised our soldiers.

Then I tried to draw her on about Greece, and Siphnos in particular. "What a lovely island you have! How superior to the others! What a splendid water source you have close to you! Do any Nereids dwell there ?' I tenderly enquired.

'Bah!' said she, 'we have none of those things now ; you may travel without the least fear.' I felt ashamed

'A curious idiom, common in Greece nowadays, by which places are spoken of as 'to the so-and-so,' reminding one of the French idiom, Le Mans and Au Mans. (Stamboul is derived, it is said, from its Greek name ' $\sigma \tau i_{i} \nu \pi \delta \lambda(\nu$, to the city.) 
of myself, and unable to explain ; consequently I left her alone, and adjudged her very unprofitable, as old dames go in the islands.

The Greeks of Siphnos, I am sure, could supply us with a few wrinkles as to how to pronounce classical Greek properly ; they do not give the upsilon the everlasting sound of $e$, which makes it so difficult to distinguish from the others. When long, as in $\chi \rho \bar{v} \sigma o ̀ s$, they sive it the value of the French cu. Didaskalos Jean was very sure that by travelling through these islands a true idea of the old pronunciation of Greek could be arrived at. I have heard the proper length of the $\omega$ and $\eta$ preserved ; aै $\nu \rho \omega \pi \sigma o s$, for instance, is sometimes pronounced with two long sing-song syllables to begin with. But a study of this kind requires the keen ear of a native; a foreigner, amidst the innumerable dialects, would get hopelessly lost.

That night Captain Prokos had a large party of Siphniotes to meet us ; we laughed and talked, and it was quite a late hour before they dispersed. He and his wife slept in the den next to ours; there was a large hole in the wall, so we could hear him talk and hear him snore. Suddenly in the night the greatest commotion arose : an inquisitive pig had entered the house, and had pushed its adventurous course right into the sty where the Prokoi slept. They are hospitable enough to their pigs by day, but they draw the line at the bedroom door. The captain and his wife yelled and screamed at the impudent intruder with all their might, but he simply grunted untif they both arose and with dire imprecations pursued him out of the house.

On the next day we visited the mines, and on the following our stay at Siphnos came to an end. We were obliged to close with Captain George's offer to take us 
to Kimolos, for in some mysterious manner he had us in his power ; for the Siphniote boatmen refused to take us ; and Captain George's caïque appeared to be our only chance. Evidently he looked upon us as his legitimate prey, and the Siphniotes dare not enter into competition with him.

It was a lovely day early in December when we parted from our friends at Apollonia. Our way led through a richly fertile country down to another harbour called Pharos, where the ruins of a white marble Hellenic tower have suggested to the inhabitants the idea that once a lighthouse (Pharos) existed there. Hard by are the traces of another similar one, called the tower of St. John, and all around are terraces and walls-unmistakable eridences that an ancient town existed here. We may almost unhesitatingly call it Minoa, for we have only three towns in Siphnos mentioned by Stephanos, of which, from inscriptions, we know the position of Siphnos; Apollonia, around the temple of Apollo, speaks for itself ; and the third, Minoa, is undoubtedly here.

By making a little deviation we were able to pay a visit to some nuns, whose convent is delightfully situated on the hill slopes, and is dedicated to the Virgin of the Mountain. Here they have a miraculous picture worshipped at the panegyris, or festival day, once a year, which is said to have special properties for working miracles on childless women, who flock here to consult this modern Aphrodite; and a wreath of wax orange blossom entwined around the frame was the gift of some grateful mother whose prayers had been answered. The church is built with the pillars of an old Doric temple. and is very handsome; but there are only six nuns left here now, who complained bitterly of their poverty, and did not scem the least flattered when we admired the 
beautiful position of their home. From the terrace of this convent we enjoyed one of those ever-changing views for which the Cyclades are noted, for every new position, every new elevation from which you see the surroundin: islands seems to add some new charm to the panorama. Close beneath us was the little appanage of Siphnos, the island rock of Kypriani, now only used as a pasturage for flocks in summer, on which was built a church, as the tradition of the elders tells us, by a pious Siphniote lady called Kypria in memory of her son, who was drowned at sea; and in honour of her own name she caused the clay of the bricks intended for the building of the church to be mixed with Cypriote wine instead of water.

Passing on from this convent we began to ascend the ridge of hills which divides the island from east to west, and had our lunch in a lovely spot, a perfect garden of wild flowers even in December, many-coloured anemones, cyclamens in full bloom peeping out of the mastic bushes with their red berries; around us were wild olives, wild juniper trees, wormwood, aromatic thyme, and caper trees; just beneath us was one of those everlasting little white churches buried in figs and olives, and the well from which we got our water was draped with maidenhair.

On reaching the summit we descended by a very steep mountain road into the secluded harbour of Bathy (deep), so called, we learnt, not from the depth of the water in the bay, but from the height of the mountains which surround it and the depth of the inlet into the land. Here is a monastery, dedicated to the archangel Gabriel, built on a rock jutting out into the sea, right in the centre of the bay. It is a pure specimen of Byzantine architecture-three transepts, two domes, and an elegant bell tower-and here we feit we could not grumble at the cverlasting whitewash which covered it. for the white 
church against the blue sea, with nothing for background and foreground but the dull rocks and olive trees, made a charming little picture. One old monk who looks after the church and the ruined cells drags out a weary existence here, which is varied occasionally by the arrival of a few fishing boats and by a few people in the summer, who come from the town to occupy the unused rooms for sea-bathing. On the day of the festival of the archangel quantities of sailor pilgrims come to visit the spot, and the old monk collects in a basket the remnants of the loaves that they leave behind them; and when we saw him all the food he had to subsist upon were these hard crusts, which he moistens with water, olives, and a few herbs. He sleeps on a bed of leaves, and if not a hermit in name he is so in deed.

Captain George and his caïque met us here, and with a favourable breeze we were soon speeding on our way to Kimolos.

\section{NOTE.}

\section{On the Ancient Gold and Silver Mines of Siphnos.}

According to Herodotus, Pausanias, Strabo, Pliny, and others, Siphnos was celebrated in antiquity for its mines of gold and silver; and these authorities further tell us that at Siphnos alone gold was found, but at Thasos and Laurion silver was also discovered; furthermore, this Siphniote gold was not dug up pure, but mixed with silver.

Now, there are two points on the island where probably we can trace the existence of these mines: one of them is now called 'the mine of the Holy Saviour,' from the name of a church hard by, or, as the common people have it, 'the refuges' (rì katapiyı); the other is called 'the fissures.' 'The first of these lies to the northeast of the island, and is close to the sea. The entrance is exceedingly narrow and low, but when inside the visitor can wander for hours without reaching the other end; it is a regular labyrinth, so that, without a guide, or without tying a string to the entrance, no stranger ought to renture in. There are the niches still visible 
where the ancient workmen put their lamps and tools; the shatp marks of the chisel are still visible, also of places where wedges have been driven in. It has a wonderfully sparkling appearance, as if silvered all over, and there is no trace of anytling but rock.

On the cliff outside are lots of little hollows called 'furnaces'

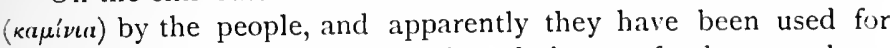
smelting purposes by means of the admixture of other metals or iron, and quantities of large stones, which doubtless contributed to the more rapid melting, lie about, and the hollows are covered with some metallic mixture. Great heaps of lead refuse lie scattered about, and are found lower down on the cliff close to a little church dedicated to St. Silvester. The people call these heaps 'remains' ( $\lambda \epsilon$ 'i (ava), and much of this was once taken to Laurion, because there became a dearth of timber in Siphnos for smelting purposes, and the hills have never been replanted.

Past the promontory which juts out into the sea just beyond the mines, on a calm day, you can see at a considerable depth large quantities of this refuse, and also the traces of hand-made works, from which we may infer that in early historical times there was one of those convulsions of nature, so common in these parts, by which the sea rose and hid the entrance to other mines. Pausanias gives this as the probable solution of the legend of Apollo's wrath and the destruction of the gold mines when they tried to cheat the god of Delphi of his due ; and the stories of the former wealth of the Siphniotes told by Herodotus and other historians tend to corroborate this presumption.

The other mine, called 'the fissures,' lies at a considerable distance from this spot on the slopes of Mount Prophet Elias. Its entrance was unknown till a few years ago because it was covered with brushwood, and it resembles in most respects the other mine in its labyrinthine passages and silvery appearance. Inside were found lots of broken vases and lamps, which had belonged to the ancient workmen. Here also was doubtless found sulphate of silver, as there are traces of silver on the walls, and around are many stones, with iron in, which had been used for the quicker smelting of the metal.

In the stream beds around both these mines, especially after a fall of rain, are found quantities of vitrified lead, which had been burnt in these furnaces, and which the people carefully collect ; for the potters of Siphnos, after the manner of their forefathers, mix it with their clay to prevent its expanding. 
Whilst on this subject I must notice 'the Siphniote stone,' which Theophrastus alludes to in his book on stones. 'There is a stone in Siphnos, found about three stadia from the sea in round masses, which is easily turned with a lathe and sculptured, when it is burnt and dipped in oil ; and it then becomes very black and hard.' They made vessels for table use of it, and the Romans made use of it, too. The existence of this stone is unknown to-day. Where is it and why does not some enterprising geologist go to Siphnos and re-develope this industry? 


\section{CHAPTER III.}

KIMIOLOS.

THIs island formed a surprising contrast to the last: instead of the fertile valleys, the rich gardens, and flower-clad hills of Siphnos, we were now on a low-lying bare island of volcanic formation. The streaks of green, red, and yellow rocks which have come out of one of Vulcan's crucibles give a curious weird aspect to everything; the soil is brown and thin, and not a tree is to be seen. We landed in a little harbour called 'Green' ( $\pi \rho a ́ \sigma \iota \nu 0)$; from the rocks which surround it. IVe walked on a little way, and everything became red; and then we went a little further, and everything became white, for now we were at a quarry of a sort of white porous stonc, easy to cut and much prized for building, for it hardens with time ; it is the old 'terra Kimolia,' out of which the ancients made fuller's earth. Close to this spot quantities of ancient pots and tools have been found, and still the little industry of the place is in this quarry. Caïques down by the Green harbour are freighted with this stone, which is taken to Athens for building purposes.

Captain George did not treat us well on this occasion, for he had deposited us, bag and baggage, at a long hour's walk from the town, where no animals were to be had, saying that in winter the harbour ncar the town was 
dangerous ; which statement we found to be not exactly true; but Green harbour was far more convenient for his return to Seriphos: hence his desire to put in there. He was a true descendant of his illustrious ancestors. 'Gracî mercari fide' is as applicable to-day as it was in Roman times; and, furthermore, the sin of lying is not one of the offences which mect with the disapprobation of the Eastern Church.

There are no mules in Kimolos, only wretched little donkeys not much bigger than Newfoundland dogs. On one of these Kera Limonià was returning from her fields, and passed us. She was off in no time, and insisted on use being made of her animal. Presently we met a cavalcade coming for us from the town, so we restored to the old woman her ass. If the donkeys are small in Kimolos, the saddles are large, and apt to sway about unpleasantly. Riding is consequently precarious work, for on the pack saddles of the island, I had to ride sidewise, and to be tipped backwards is a sensation I only cared to try once. So in Kimolos I preferred to walk.

It had got quite dark by the time we reached the solitary town of the island. It is a walled town-that is to say, like many of these island towns, the backs of the houses form a wall all round, and it is entered by a gate at either end. The streets were, as usual, filthy, and the houses entered by steps, which project into the streets, below being the stable, the warehouse, and the pigsty. On the steps were platforms, where all the gossips of Kimolos sit whilst they ply their spindles and pull their neighbours to pieces. When we issued forth next morning every platform was covered with a staring crowd, and it was a trying ordeal to walk down the main street in imminent danger of stepping off the narrow ledge, called a footpath, into that abominable mire. 
Our accommodation at Kimolos was not very grand: the house had only two rooms, the inner of which was given to us as a reception room, feeding room, and bedroom. That evening we had a crowd of visitors-the priest, the schoolmaster, the harbour master, the doctor, the demarch, and the eparch of Melos, who chanced to be here on a visit. Men and women of an inferior grade feasted with their eyes upon us from afar-that is to say, from the other end of a room about fifteen fect lons. There was a window at the head of our bed into the adjoining room, where slept our servant, our host, Captain George, and goodness knows how many others. They talked in a high-pitched key all night, and if they wished to address a sleeper they called him by name till he awoke; rarely throughout the night was there a quarter of an hour's peace.

And then the little oil lamp kept burning all night before the household sacrarium, or corner full of sacred pictures, is a great nuisance. By daytime these sacraria are pretty features in a house: some old hallowed wooden pictures, worn out by kissing ; some gaudy new ones from Mount Athos in gilded frames; the wedding crowns of the host and hostess, enclosed in a circular frame; a few religious pictures from Russia; and the brazen censer in which on Saturday incense is burnt to sanctify the house: but at night the ever-burning lamp casting a flickering light on this sacred group is unpleasant, especially when the rays fall on the eikon of St. Michael or some other horrible picture of a saint who has undergone tortures innumerable. Every householder has his ' name saint' amongst this group, and the day for celebrating the birthday is the day of the saint.

Next day we found our hostess and other ladies of Kimolos eager to come in long before we were dressed: 
they are excessively primitive in their manners, with little modesty, and an apparent desire to be hospitable ; they are very communicative, too, about their customs and beliefs, and never see anything ridiculcus in the most extraordinary superstitions.

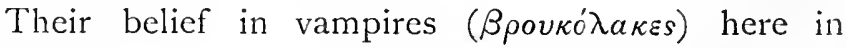
Kimolos is very firm, and though in Greece the heads of the Church are now set against allowing the people to hold such beliefs, which at one time were in a measure sanctioned by the Church, yet it takes a long time to eradicate superstitions which have lived for centuries. It a dying man curse himself, or any enemy of his shall curse him when at the point of death, that man will become a vampire. The earth cannot dissolve his body ; he will wander about at night strangling men and beasts, and sucking their blood. There is no peace for him in Hades, no peace for his relatives, for he returns to his home and 'feeds on his own,' as the expression goes ; he brings with him plagues, typhus, cholera; the grass dies near his grave, the flowers wither, and are eaten by worms, ruin comes on the herds, and dogs wander ominously about the streets howling in the night.

Kimolos and Melos, more than any other islands of the archipelago, have been visited by pestilential scourges; consequently in these islands the belief in vampires is more rampant than elsewhere in the Cyclades, except, perhaps, in the wild north of Andros. And during the piteous ravages of pestilence, religion, they say, alone can assist to quell the spirit, and by liturgies alone can the Papas set things right. Now, in the nineteenth century, we do not see what Tournefort did in 1700 , for, except in Northern Andros, they do not exhume the body, burn it, and cast the ashes to the winds; this has been strenuously forbidden by the archpriests; but what they still do in 
Kimolos is this: if there is a suspected case of vampire they go to a priest-for there are plenty of ignorant priests who pander to the superstitions of the peoplehe accompanies them to the grave of the supposed ghost, and on bended knee they supplicate the AllMerciful to have compassion on this wretched being. : May he be after death for ever unloosed like stones and iron,' says the Church formula, which in darker ages was written by Chrisophoros Angelas to meet this emergency, and on the grave the priest pours some boilings water and some vinegar. After this ceremony it is generally observed that the ghost stops his wanderings; many. affirm that whilst the scrvice is going on they hear the rattle of the bones as they settle in the grave.

This idea of vampires is, of course, very old ; nearly all creeds and superstitions have taught that wicked men cannot rest after death. Homer tells us ('Od.': ii. 49) that the shades in Hades had an idea that by filling themselves with blood they could return to life, and consequently eagerly supped up the blood of slaughtered sheep. So now a poor ghost sucks the blood of a relative, and gains for himself strength. Vampire dread is, however, rapidly on the decrease--I doubt if a single one of the rising generation will belicve it.

These are not the only kind of ghosts they have in Kimolos; it is a volcanic island full of caves and uncanny spots: these invariably excite, beyond control, a belief in the supernatural; consequently in Kimolos and Melos all sorts of old superstitions survive.

If they build a house they will kill a goat and a bird, with the blood of which they make a cross on the foundation stone; and for this ceremony the Church has an office and a prayer. If a murder has been committed in a house, or a man buried at midnight, shadows will 
come out and terrify the inhabitants. At houses such as these they get the priest to read an office and a prayer to drive out the demon; on this occasion again the Church is ready. If this is not successful the house is deserted, and just outside the walls of Kimolos are several houses which, I was told, were deserted for this very reason.

On the hill over the town, near some windmills, are quantities of caves where Nereids dwell; ' and the Nereids of Kimolos,' said our hostess, ' perform the duties of maternity just as we do, only their great desire is to have male children;' she illustrated her statement by the following story. 'One day a Nereid of the cave was expecting her confinement, and sent for the regular Mrs. Gamp, of Kimolos, to attend upon her, saying, at the same time, "If it is a boy you shall be happy, but if it is a girl we will tear you in four parts and hang you in this cave." Clever Mrs. Gamp was determined not to be quartered thus, so when a girl arrived she made believe it was a boy, swaddled it up tightly, and went home. Eight days afterwards they unpacked the child and were miserably disappointed. So a Nereid went down and knocked at Mrs. Gamp's door. Again she was too cunning for them, for she knew the rule that if you answer the first knock of a Nereid you become mad. So the spell of the Nereids was lost, and could not hurt her ; in fact,' concluded our hostess, 'she is alive to-day, and can tell her own tale.'

This story is told substantially the same in other islands with pleasing varieties; in Anaphi, for instance, they say that the Nereid offered Mrs. Gamp a bag of gold if the child was a boy. Mrs. Gamp invented the same deceitful plan, but the Nereid was equal to her. She sent her the bag indeed, but it was full of onions instead 
of gold. From the solemn way our hostess told her story, from the constant corrections of those around if they thought she was not telling it rightly, we could but feel sure that she and her female friends firmly believed in this interesting episode in a midwife's career.

The morning after our arrival the ladies of Kimolos were very busy, for it was St. Katharina's Day. They made us go to an early mass first in the Church of St. Katharina, which was all decorated with evergreens, daphnes, myrtles, and flowers, cyclamens, basil, \&c. ; from thence we went to the Metropolitan Church, a new one just outside the town, which had been built only recently by the joint co-operation of the males and females of the place, who gave their services gratuitously: the women brought all the materials together, prepared the mortar, and did all they could, leaving the men to put them together. The Kimoliotes are a very pious race of people. How fervently they kissed the silver eikon of the 'guicl-

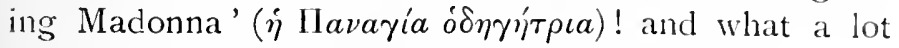
of moncy the priest was getting, who stood at the door, as he gave a bit of sacred bread and a cross of sacred oil to each who passed, and got in return the money, the 'return gift' ('́) of gift for gift is very marked in Greece; if you give a Greek woman a trifling present, off she will set to her drawer, and fetch you something she thinks an equivalent to your gift : there is something painfully barefaced about it to our ideas.

We witnessed a very sad case in this church. A poor young sailor had just returned the clay before, raving mad, from a voyage, and his fellow-sailors gave the following account of the cause. As they rounded Cape Malea a terrible storm came on, and the light called Telonia was seen at the masthead, and the poor 
young fellow had fallen a sacrifice to the demons of the air.

Greek sailors, like Italian ones, who call them 'the fire of St. Elmo,' have a firm belief in the evil omen of these atmospheric lights; and they try to exorcise them with magic words or by shooting or beating brass instı uments ; they personify them still as birds of evil omen, which settle on the masts, just as Ulysses did on his travels. By land, however, they look upon them as demons, which dwell in the air, and prevent the migration of souls from earth to heaven.

The poor young fellow immediately on reaching home had been taken to the Church of the Guiding Madonna, for it was evident to all that he had lost his reason, whether these strange lights had been the cause of it or not. Whenever a person becomes delirious or wanders in his mind the doctor is sent away, and the priest is called in ; if able to go they take the sufferer to the church, if not the priest visits him at home, and the church bell is rung to drive the devil away. In the event of the patient dying in torment or convulsion the priest preaches to the sorrowing bystanders about the awful struggle between life and death, heaven and hell; in the event, however, of his recovery the priest says, 'This is a miracle,' and expects a handsome donation.

It was a distressing sight to see the young man, with wan face and wandering eye, surrounded by his sorrowing friends. They had been with him in the church praying all night, and they intended to keep him there all day, hourly hoping for the Virgin's favour to be granted to him. I felt much interested in the poor fellow, but there was no better account of his condition before we left the island.

It was our good fortune to come across a ceremony of a different nature in a house we went intn soon after. 
Some girls were busy making what they told us were St. Katharina's cakes: the recipe is simple, and as follow's. Take three handfuls of flour and three of salt, get an old woman who has been married once to mix these. Then make them into cakes and, tasteless and salt as they are, eat them lying down and call upon St. Katharina to intercede in your behalf and send you a husband. When this is done the girls try to go to sleep and dream, if possible, of a desire to drink and of some gallant young man handing them a glass of water. If they dream this, the young man is the husband destined for them by St. Katharina. It is not to be wondered at that their dreams sometimes turn in the direction of a desire to drink and of young men when they have eaten so much salt and thought so much about husbands.

I never saw the girls again to ask them the result of their experiment, but I do not doubt that sooner or later they will find helpmates, for they werc pretty girls, with an Ionian type of countenance, round faces, and those curious almond-shaped eyes. This is distinctly the Kimoliote type, another very pretty specimen of which appeared to us that evening in the old Kimoliote costurne, which unfortunately has now been entirely abandoned, except on rare festive occasions.

On the head is a thing they call the $\kappa o v \rho \lambda i$, bcing one of those Eastern veils we use as antimacassars, thrown over a ring of false curls. From the shoulders to the heels was a robe of silver brocade, covered with gold and coloured flowers, long loose slceves, and stomacher. The woman was well adapted to show this dress off, being very tall and handsome, with such dark almond-shaped cyes and such a mouthful of pearly-white teeth, or, as they express it here, 'such a cave full of white horses,' that she seemed quite regal to look upon. 
They talked of getting up a dance that evening, in which all the women were to appear in robes like this; but it was delicately hinted to me that I should be expected to stand the supper and pay the musicians; so I told them as politely as I could that, with the prospect of a hard day before us on the morrow, the best thing we could do was to go to bed.

In spite of threatening rain, and the usual difficulties attending a prospective wetting in this country, we managed to get off pretty early next morning on our way

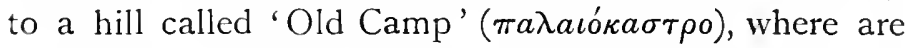
the ruins of the old fort capital of Kimolos.

When once the present town is left behind there is very little trace of habitation or life on the island. A bright-eyed shepherd boy accompanied us part of the way, with bare legs and a gcat's skin bag on his neck: he was musical, according to the Greek conceptions of music, and sang us several low, monotonous songs. Then we came across some women gathering saffron on the hillside, with which to flavour their bread and their fish; and about the time for our midday meal we reached a shed, or mandra, close to the old camp, where a shepherd lived in much the same state as the herd of Ulysses lived in on Ithaca. Dogs came out barking to meet us, as if we had been Telemachus; and we stooped to enter a low cabin, consisting of one room, made out of large stones roughly piled together, and letting in the wind at numerous cracks. Across the roof ran beams, into which all the articles of husbandry were thrust; a place for a fire was in one corner with no outlet for the smoke; in another corner was some straw for the herdsman's bed; outside this wall was the semicircular enclosure for the cattle, on the wall of which was placed dried branches of prickly brushwood to prevent them from cscaping. 
The view from here was more curious than pretty; it seemed as if in the centre of the island there had becn the crater of a vast volcano; and it is still called 'the cone.' Down by the coast we were pointed out a spot where hot healing springs emanated from the rocks, and where once was a bathing establishment; but now this has almost fallen into the sea, and those that want the waters must go and return to the town by boat all in one day.

'Kimolos is the spot,' says Tournefort, 'where corsairs spent in horrible debaucheries the booty they took from the Turks.' Now these caverns where the corsairs bivouacked are still looked upon with dread by the inhabitants, for from their volcanic nature the rocks frequently split with horrid noises, and fall to pieces, thereby terrifying the superstitious labourer as he sows or reaps his crops.

The old camp has a grand position on the highest point of Kimolos, and has traces of having been used, both in ancient and medieval days, as the acropolis of the island. There is the medireval wall, some three feet thick, running in conjunction with the ancient wall with colossal stones; on the summit are cisterns and places of sepulture, now used as shelters for cattle. And, indeed, we were glad enough to take shelter ourselves in what presumably was once a reservoir, for the rain came on in torrents; and being a thousand feet above the sea, well on in December, it was rather cold. But on our return journey the sun shone out once more, and made us dry and warm before we reached home.

That afternoon, just after our return, my wife admitted to a headache, more out of a yearning for solitude and repose than out of real pain. Without a moment's hesitation our hostess went to fetch her mother, an old, withered hag of seventy or more ycars, who volunteered 
to cure the ailment by her magic art and the accompanying incantation. Out of her pocket she drew a large pocket handkerchief, in a corner of which she tied a slip-knot. This knot she laid on her knees and put her elbow on it, and then with great deliberation proceeded to measure to the opposite corner from her elbow to the middle finger, nipping it between the fingers till she laid the first finger of her left hand straight across the measured mark. The handkerchief went three times, and about four inches over; this bit of four inches she held in her left hand, and waved with her right the knot vigorously across and over the sides of the patient's head, saying, as she did so, the following incantation :--

Down on the beach,

Down on the seashore,

Thousands, myriads were seated,

And were romiting and to God praying.

When Christ went by

With His twelve apostles, and said,

"What is the matter, My children?

Why are you vomiting? why are you being purged?

Why are you imploring the aid of God?'

'O my Master, my Christ !

You know all the secrets of the world,

Yet do You not know the things that are plain :

We have a sunstroke, and are being purged,

And are vomiting, and we are imploring God.'

'Put cold water in a vase,

With it the leaf of a myrtle

And the shoot of a bramble

Pray then, and say,

"Holy Panteleomon!

Holy Anastasia !

Poison and cast out this sun,

The pain, and all the evils from the man." 
Thanks to the kind interpretation of our hostess, I was able to get the words which the old woman mumbled in an inaudible voice, and flatly refused to repeat more distinetly. Then she measured the handkerchief again in the same way, and by some sleight of hand it only seemed to reach three times. 'Ah!' she exclaimed, 'you are suffering from the sun, for the handkerchief has got shorter; if you have nothing the matter with you it remains the same length, if you are suffering from the sun it gets shorter.'

After dabbing cold water on the patient's head, and muttering the same incantation over again, the old hag promised immediate relief at sunset; and at sunset she measured again and pronounced the cure to be effectual, as the handkerchief did not shorten. The patient could have told how the pain never really existed, but it was only kind to tell the old thing what a clever doctress she wai. By what sleight of hand she managed to measure the handkerchief shorter and longer at her will remained a mystery to us, though we watched her narrowly. There are a great many of these charms in the Greck islands. In Amorgos I saw the stomach-ache charm. Elscwhere thcy have incantations that they sing to the new moon when people look pale, and another they recite to the moon and to flowers is reckoned highly beneficial for those fleshy swellings which grow on the hands, and which have no importance beyond inconvenience. It runs as follows:--

I bow before you, new moon;

Glory be to thee wherever thou mayst be,

Basil and myrrh, that the ants may eat.

Now warts are called 'ants' in these parts, from the numbers in which they come : hence the allusion. Nany others are utterly mysterious, and only known to ecrtain 
old hags, just as in ancient Athens secret cures were kept up in families-medicated rings, prepared plants, \&c. Plato, in his 'Laws,' treats of charms and incantations, and tells us that the accompanying songs were essential to success. "Without the incantation the herb would be of no avail' (Charm, p. 155). In Byzantine days these musical incantations were in great repute, as we read in the pages of Psellos and others; and amongst these islanders many quaint remedies are still in vogue. As a cure for jaundice put a piece of gold into a glass of water or white wine. This they expose to the air during the night, but are careful to take it in before sunrise. They drink it on an empty stomach, and in two or three days are well. The idea is that gold will attract to itself and fix in the water that substance which vivifies everything, and which exists in the midnight air.

We bade farewell to Captain George next morning without any serious pang: he was busily preparing for his return to Seriphos with a favourable breeze, and was eridently quite content with the results of his outing, for he was humming gaily to himself one of the island sailors' favourite couplets :--

The sea is my mother, the wave is my brother, The pebbles on the shore I lovingly adore.

And when we met him again, in Syra, some months later, we were the very best of friends. We did not part from our host and hostess of Kimolos in quite so friendly a fashion; they evidently looked upon us as legitimate prey, and charged us accordingly. But these good people are not well up in the ways of the world; give them what you think just firmly but kindly, and when they see there is no hope of getting any more they unblushingly give in, and become overpoweringly friendly again. 
It was our plan to visit a spot called Hellenikit before crossing over to Melos, where are the remains of an extensive old Hellenic town on the west coast, just opposite Melos. The demarch of Kimolos showed us a collection of treasures that he had dug up there; the property is his, and, for fear of having to give up his treasuretrove, he goes there with his workmen and digs by night ; and we heard fabulous accounts of the wealth he had acquire by his 'finds.'

The ancient site of the town of Kimolos has been hunted over before by antiquarians, for Mr. Brest was consul here for France, and in I 799 was a sort of king in the island in those days when French sailing ships used to take their pilots for the archipelago from Melos or Kimolos 2 A special French consul lived on Kimolos, because the ships used to stop in the good harbourage which lies between the two islands; and Mr. Brest used to intercede with the Kapitan Pasha, who came to levy taxes, on behalf of the inhabitants; consequently he was omnipotent here. Mr. Brest it was who in after-years discovered the Venus of Melos, and his son (now an old man) is still everybody's vice-consul at Melos, and a man of weight. From Kimolos old Mr. Brest used to feed many of the European museums, and opened many profitable tombs long before the demarchs existed.

From the extent of the foundations one can argue that once this town was of consiclerable importance, and we are told that silver mines once existed in the island, and in the middle ages it was hence called Argentiere. About 200 yards from the shore at Hellenikà there is a rocky islet called St. Andrew, or Daskalio, which is covered with remains of ancient houses, broken statues, and graves at the bottom of the sea; as we rowed across we could distinctly see a lovely sarcophagus, which the boatmen 
told us they had often tried but never succeeded in raising. Amongst the islands there are several rocks, just off the land, near an ancient town, which are now all called Daskaliò ; there is one off the old capital of $\mathrm{K} y$ thnos, there is another off the ancient town of Karthaia, in Keos. The prevalent idea is that they were once places for study $(\delta \iota \delta a \sigma \kappa a \lambda \varepsilon i a)$, where philosophers used to retire for quiet; but this can hardly be, for there are traces at Kimolos of the rock having been once joined to the mainland by some arches of wave-washed rocks, which stand up in the sea; so that it would appear that the waves had made their way and destroyed a natural breakwater: consequently the retirement of the philosophers must have been seriously interfered with.

On the mainland there are foundations of houses, tombs, and hollow caverns, extending for a long way along the coast, which do not yet seem to be exhausted as a hunting ground for treasures; for as we walked along we found almost buried in the sand a well-formed glazed kylix, which gladdened our hearts and sent us on our way rejoicing.

Between Kimolos and Melos the strait is only about half a mile wide, but we had the greatest difficulty in crossing it. There is a regular boat which is supposed to cross when travellers require it, but there was a little breeze, and the boatmen affirmed that their craft was rotten, and only sailed when the sea was calm; and if it had not been for a soldier, whom the eparch had given us as an escort, and who wished to carry a basket of fresh eggs he had with him for sale at Melos, we should probably have had to pass the night in a tiny church which is used as a signal-box for those who travel between the two islands. 


\section{CHAPTER IV.}

MELOS.

As we landed on Melos the sun was 'seeking his kingdom in flames of blood,' as a Greek peasant would say; for he is a wonderful hand at personifying what he does not understand, much in the same fashion as his forefathers did. The sun is still to them a giant, like Hyperion, bloodthirsty when tinged with gold. The common saying is that the sun, 'when he sceks his kingdom,' expects to find forty loaves prepared for him by his mother to appease his hunger after his long day's journey. Woe to her if these loaves are not ready! the sun eats his brothers, sisters, father, and mother in his wrath. 'He has been eating his mamma' is said when he rises red of a morning.

To-night Phœbus Apollo was returning angry to his palace, forcboding ill to man. The boatmen, on arriving, congratulated themselves on having crossed safely. 'Tomorrow,' said they, 'we shall have bourrini, namely, those fitful storms which visit these islands during the forty days' fast before Christmas, before the north wind has settled down into the steady blow which gencrally makes the carlier months of the year cold in Greece. In the crimson evening light the shores of Melos looked anything but hospitable--bleak, barren, and volcanic on this side of the island, which is fully three hours' ride from 
the town; there were only three fishermen's hovels and one windmill. This spot is called Apollonia, and here once stood a temple to Apollo. The best of the horels was indeed a sorry place, consisting of one room, seven feet by twelve, containing a dirty bed on boards, two stools, a low table, and a mud floor-even the potter's shed at Siphnos looked more inviting than this. We sat down moodily to eat our dinner, which consisted of caviare, rye bread, and water; the good lady of the house could find us nothing else. She was very poor, she said apologetically, and had only lately lost her husband, who lay buried in the sand by the seashore hard by. She pressed us hard to stay the night, promising that she and her daughters would rest elsewhere, and that we should have all the house to ourselves. She spoke of the terrors of the way, but we remained firm ; and as soon as a quorum of donkeys was secured we set off by bright moonlight, at half-past six, on our journey towards the town.

I have seldom seen anything look more weird than Melos did by this light-great yawning caverns on either side of our path in the tufa rocks, which stood up tall and thin like towers and steeples. One of our muletcers was a lively girl, Ekaterina by name, who could tell us the names and attributes of all the hobgoblins that haunted these white rocks. She was a bit of an astrologer, too, and pointed us out the Pleiades, the Jordan, Noah's Ark, David's chariot, and other stars, which names reminded us of the ancient ones. Curiously enough the Jordan is nearly always used in modern Greece where the Nile was anciently. For instance, at Delos there is a spring which mysteriously comes up from underground: the ancients said it came direct from the Nile; to-day they tell you it comes from the Jordan. Again, David's 
chariot is the old chariot re-christened, the Charles' Wain of Western Europe.

As we went on clouds overshadowed the moon. 'The storm is coming on,' said our female muleteer. And then she went on to explain to us her theory about rain; how the vault of heaven is full of holes like a sieve, and how God pours water on to it out of skins, and somctimes He squeezes hard and sometimes softly. 'To-night He will squeeze hard,' she said, for the approaching cloud was densely black. So we turned aside into one of those deep, yawning caverns, mules and all, and our muleteers collected brushwood with which to make a roaring fire, which shed lurid rays out into the darkness and the descending rain. We were told we should have to spend the night here, but this we flatly refused; and as soon as the violence of the storm was over we set off again, and reached the Kastro, or chief town of Melos, before eleven o'clock. With the exception of two or three villages close by, the Kastro is the only place of habitation in the large island of Melos. It crowns a lofty conical hill, half-way up which we had to climb before we reached our destination. This time we were to be taken in by a military man, Mr. Photopoulos, who at our first knock refused admittance, thinking we were thieves or brigands, for no steamer had touched in Melos harbour lately; there was no possible reason to expect anybody. Lcarning, however, through the keyhole, that we were English, and knowing, as he afterwards told us, that 'we were a capricious and daring race, capable of travelling by night,' he opened his doors, and gave us a hearty welcome.

We were, by comparison, in the lap of luxury under the roof of the Photopouloi. He had a charming house, looking down upon the harbour, and took great pride in telling us how five ycars ago he had arrived in Melos a 
penniless officer; how he had won the heart of the greatest heiress in Melos; and how he had established himself in her ancestral home. The morning was bright and fine, and we were enchanted with our view. Melos is a long, narrow island, shaped like a horseshoe round its glorious harbour; at one extremity is the inhabited part, the Kastro, and the villages around it ; at the other extremity is the lofty summit of Mount Prophet Elias ; whilst the central portion is comparatively flat and fairly fertile. No island in the archipelago has suffered more from the vicissitudes of the last century than Melos. During the Turkish rule it was prosperous, being the home of hundreds of pilots employed by the French corsairs, who were, comparatively speaking, at that time masters of the Levantine seas. M. Beneville Temencourt, Chevalier d'Hoguinan, and others, who used to overrun these seas, brought their prizes here to Melos, as to the central fair of the archipelago, and the townsfolk of Melos welcomed them gladly.

As a proof of the independent spirit of Melos 200 years ago, I will mention the career of a corsair, Capsi by name; an instance of one of these princes who ruled for an hour. In 1677 , with the support of his compatriots, he made himself judge-nay, almost king-of Melos. He was a clever man, and governed with considerable tact ; but one day he foolishly listened to some specious promises given him by the Kapitan Pasha, and went on board his ship. No sooner was he safely there than the Pasha set sail with this would-be ling, who was executed shortly after at Constantinople.

Tournefort tells us that when he visited Melos twenty years later all the productions of the island were of incomparable excellence, and Consul Brest stated that his father had told him that when he was 
young Melos was most fertile, and had upwards of 20,000 inhabitants. But the invention of steam, and disease have combined to destroy Melos: owing to the former ships do not find it necessary to stop at Melos, and the corsairs' fair has been long since abandoned; and owing to the prevalence of the latter, at the beginning of this century, the inhabitants thought the island was under a curse. The old capital was abandoned, numbers fled; and if it were not for refugees from Crete, Melos would be now almost uninhabited. Only 7,000 are now left, and many houses in the Kastro are falling into ruins. There is lack of energy nowadays in Melos, for Syra monopolises all the trade that once came here, and the Cretan exiles refuse to cultivate as they ought the fertile centre of the island, for they are only awaiting a favourable turn in events to return to their own island. Even the fishermen complain that the fish have left the port, owing to the unscrupulous use of dynamite of late years as an easy means to kill the fish. If only. Melos could have been chosen as the centre of commerce how much better would it have been than Syra! The harbour is excellent, and then ballast could be taken of sulphur, salt, and millstones, the products of Melos, whereas on bare Syra they can get nothing but common stones.

Mr. Photopoulos, in full uniform, took us out for a walk after breakfast; and we directed our steps up towards the citadel, and were at once struck with the great feature of Melos ; namely, the quantity of churches and miracle-working pictures. This is easily accounted for by the numerous plagues which have swept orer the island. First we visited 'my Lady of the Sea' (i Mavayia $\theta a \lambda a \sigma \sigma i t \rho \iota a)$, the pilots' church, high up on the hillside, where the Madonna has taken the place of Aphrodite $\varepsilon$ v̈r $\lambda$ oı a. Years ago this church, which is of good 
Byzantine style, was falling into ruins, when the smallpox broke out badly, and a pious Meliote dreamt he saw my Lady of the Sea, who bade him build her church anew.

Over a side door are the arms and initials of John Crispi, 1553, one of the last dukes of Naxos; inside there is a richly carved tempelon of doves plucking vinetendrils ; the women's portion of this church ( which is on one side overlooking the sea, has a lovely view, which must be distracting to the female prayers if they have any soul for beauty in them. Here they have an altar all to themselves, and can hardly see into the body of the church. In former years the seclusion of the fair sex was more stringent than it is now. St. Basil, so runs the legend, once detected a woman winking at an officiating deacon, and for her offence her sex was doomed to be veiled off from the males: this veil is now altogether abandoned, but is usually replaced by a screen of trellis-work.

From the acropolis the view is still lovelier. From this vantage ground the pilots used to strain their eyes and telescopes in the direction of Cape Malea, and whoever first ascertained the name of a ship rushed down to Consul Brest, and had the vessel allotted to him as his job. This method resulted, as may be supposed, in over much squabbling; so now it is ordered that each pilot shall have a vessel in his turn.

The Kastro and the surrounding villages are built of a light stone, which takes a darker colour in the air, having somewhat of a ginger-like appearance ; it is excellent for sharpening iron upon, and is undoubtedly the pumice of the ancients, which Pliny mentions as being useful for softening the skin. About in the Kastro and villages there is still a good deal left. 
Of the old costumes the headdress worn by many women is called, as at Kimolos, the rovp $\lambda i$, but it is worn differently, being a thin white muslin veil tied round the chin and then bound round the head in crossing folds, and hanging down bchind. Two curls appear or either side, and with a blue dress, and sometimes, though now rarely, a stomacher, we have the everyday dress of a Meliote woman. At the village of Triobasalla, about two miles from the Kastro, we saw the dress they wear on Sundays and feast days-quite an elaborate costume.

For the headdress they have a padded foundation, edged with gold lace, over which they twist the muslin handkerchief; their jacket is of purple silk edged with fur, and their skirt is of satin spangled with white flowers; a stomacher of silvered brocade, and a silk gauze apron edged with old Greek lace, and dainty little shoes complete the costume.

As we wandered amongst the villages near the Chora, we found many interesting objects for observation. At Trypetè, so called from the holes $(\tau \rho u ́ \pi \eta)$ or rather ancicnt tombs cut in the rock close to, we found them hard at work dancing this same Sunday evening. What inveterate dancers these Grecks are! There, in a small room about fifteen feet square, they were performing the syrtos. The children of the family had been piled on the bed, boxes and articles of daily use had been roughly shoved away into corners. Crowds of people were looking on, yet the charmed circie was well kept, and the dancing, though not so good as what I saw elscwhere, was fair cnough, and some of the local steps were pretty. The pcople of Trypetè owe a debt of gratitude to their clead ancestors, for the tombs in the rocks make cxcellent stables for their mules, pigsties, and offices. 
There is another village close to called Nychia, or 'O $\nu$ ' $\chi \iota a$, from the idea that giants have clawed the vol-

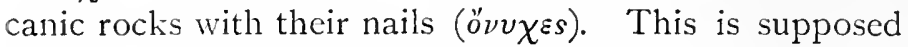
to be a very ghostly place, where many people have been seized by uncanny Nereids, as also are the valleys of Plathena and Pheropotamos, a clayey spot, where women have been known to disappear altogether in the mire. Fishermen say they hear women singing about here, and stones are hurled at their boats, which cause them great trepidation. I am convinced the reciters of these stories thoroughly believe in them themselves, for they will tremble as they relate them and cross themselves vigorously.

Another village close to the Kastro is called Plaka, and here is a church dedicated to the "Virgin of the Rushes,' for a black picture of her was found amongst some reeds not far from this spot. They took it to the then capital of the island, Zephyria, but a pestilence broke out, and they were obliged to bring it back and build a church for it here. A short distance beyond Plaka is a tiny little church dedicated to the manifestation of the Virgin, where a very curious custom is still observed, not, however, so frequently as it used to be, for it is against the law. When a child becomes emaciated they say it is struck by the Nereids, who dance in the dry bed of a river close to this church. If no physic benefits the little sufferer it is an obvious case of Nereid disease, and the only cure for this is to take it, strip it naked, and leave it on the cold marble altar of this little church for a season. To effect a radical cure the child should remain there all night, but the mother is afraid of detection, so dare not leave it there so long. If the babe survives this treatment it is not struck by the Nereids, and the parents' peace of mind is restored; but 
if, on the contrary, as often happens, this treatment is fatal, the parents are content to think that God has willed that their darling should fall a victim to those evil spirits. The little church is a quaint spot. The high altar on which they place the children rests on a fluted pillar of ancient date, for the spot is just over the ruins of the old town and the vale of Klima, which we decided to visit at the end of our stay in Melos; for, as the weather looked favourable again, we thought it best to take advantage of it to visit the deserted western horn of the island.

Accordingly next morning we set off in a boat to cross the harbour. As we went we had a better opportunity of realising its beauty and extent : it could hold all the navies of the world within it, and it is protected by an island at its mouth. On the western point is a mountain called the Vanis, a wild, bleak spot. on which our boatman told us that it was the custom to throw bread when they sailed out, that Vanis might eat and send them fish in return.

On the opposite side are two or three houses used by wealthy Meliotes as summer resorts; one of them belonged to Mr. Photopoulos, who gave the key of it to our escort, the soldier, and bade him make us as comfortable as he could. But what a place it was! The walls were running down with damp, not a dry rag could be found to put upon the bed, no means of warmth whatsoever. So we gladly took refuge in a neighbouring cottage, where a farmer lived, who cooked us a trifle whilst our mules were being captured and got ready.

Few expeditions in the Cyclades are more repaying than this one to the Convent of the Iron St. John ( yıàvve), on the western horn of Mclos. The path takes you in and out of wild valleys at the foot of Mount Prophet 
Elias. Scarcely a house is passed on the road-only a mandra or two, and goatherds near them tending their flocks. For a second time in Melos we had a female muleteer, an intelligent girl of about ten, who busied herself in gathering for us the red arbutus berries (still called комápo ), which were just now ripe, and the gorges were lovely with them. We passed by cleft after cleft full of oleander, and locust trees, wild olives, cedars, and wild mastic, the black berries of which our damsel made us taste : they are simply horrid, and taste of varnish, but the peasants about here are very fond of them, and put them instead of anise seed into their rye bread. In this dense jungle on the slopes of the mountain we turned up lots of woodcuck and coveys of red-legged partridges, and came across two or three sportsmen from the Kastro with their dogs.

Our girl mulcteer was quite a botanist in her way. She first picked us a sprig of a sort of thyme $(\theta v \mu \varepsilon \hat{\imath} o \nu)$ with long spikes, which she told us was reckoned exceedingly warming and genial to an aching stomach, and then a bunch of an exceedingly sweet aromatic herb, which she said they bruised and put into nuptial couches. Then she knew the different plants that were used as saladsthe wild cabbage and so forth-and those that they only give to cattle; but she had an utter contempt for flowers - cyclamens, anemones, daisies. Whatever we asked the name of, her reply was always the same, 'Bah! those are only loulouthia, not good for anything.'

On the slopes of Mount Prophet Elias we were told that wild goats are found; we only saw tame ones, and they were plentiful enough; and in the mandras we passed we saw heaps of kids with scarecrows near them to frighten away the eagles. The Mount of the Prophet is a fine conical one, on the summit of which, as a matter of 
course, there is a church dedicated to the modern sun god: the slopes are of a reddish rock, with streaks of red earth here and there, which is used for making roofs to houses. And through the bright green carob trees the views of the red mountain and blue sea were exquisite.

About midday we reached the convent; not a soul was there ; the church was open, and so was the courtyard, and the sheds around where people pass the night who go to the two yearly pilgrimages. Before reaching the building we passed through a wild waste of rock, and on each rock the pilgrims with pious intent place little cairns to indicate to the saint that if they are well they will return next year. With each stone they wish a wish, and if every wish were answered, thought we, what a happy people those of Melos would be! They do this still in the East-a relic doubtless of the old custom of raising menhirs - and along all the main routes stone monuments are erected by Moslem pilgrims at the point where a shrine first becomes visible.

There is a curious legend attached to this desolate spot. Years ago, when a festival was being held here, pirates were seen to be approaching, and the people crowded for safety into the church, the doors of which shut of their own accord, and were immediately barred with iron by the kindly interposition of St. John. One daring robber climbed upon the dome, and tried to fire down on those inside, but his hand withered, and the pistol fell from it. The pistol is still preserved and much thought of by the pious; close to it were preserved some other relics-stirrups, \&c.-the value of which I could not learn. The spot is an enchanting one, and the view from the courtyard, with its spreading locust tree, under which the pilgrims erect booths at the time of the feast, is well worth the pilgrimage thither. A few miles 
out to sea is the island of 'Desert Melos' (Erimomelos, or Antimelos), which rises sheer out of the sea, and from a distance looks as if it would be impossible to land thereon. I rather wanted to visit it during my stay in Melos, but learning that there was not a house on it, and that in winter I might be detained there for days, I was forced to give up the idea, and be content with what the Meliote sportsmen told me about the curious species of deer which lived there, and which from the description I fancied must resemble the mouflon of Corsica, and about the ancient cistern there which is never dry in summer, and which has steps into it so that the animals can go down to drink as the water recedes. If this account be true it is evident that Erimomelos in ancient days must have been used as a sporting ground for the Meliotes.

After a wretched night in Mr. Photopoulos' summer residence we set off early, breakfastless and cross, on our ride home round by the centre of the island, not over-grateful to our friend who had promised us we should find every luxury and convenience over here.

An hour's ride brought us to the Convent of St. Marina, now nearly in ruins, but which was once the richest convent in Melos. Here we were told that we should get our breakfast, but it consisted only of rye bread, with black mastic berries in it, coffee, and a pull at a public raki bottle. In the church there were evidences of former grandeur-rich carvings and frescoes-rapidly falling into decay ; for the few peasants who now live in the cells, and have made a hamlet out of the remains of the convent, do not interest themselves much in their church beyond sweeping it out in turn and keeping the lamp burning before the altar.

After learing this spot we entered upon the low central part of the island, where the soil is perfectly alive 
with volcanic matter. On a slight eminence about halfway between the two seas is what one might call a natural Turkish bath, much frequented by Mcliote invalids. It is doubtless a volcanic crater, on the top of which a rude shed has been built. On entering you descend a gentle slope, which leads into a small hole with three stone stools in the bowels of the earth, where the temperature is steaming hot---hotter than the hottest room in any Turkish bath I ever knew. Here in summer time rheumatic patients come, and after the operation of sweating is over they recline on beds made of straw and olive twigs in the shed above to accomplish the cooling process.

All around the country is covered with vineyards, which at one time must have been fertile enough, but now for want of men to look after them thcy are fast becoming wastes of stone; a few varicgated cedars grow about here, otherwise it is a bare, uncanny spot-a great contrast to the verdant slopes of Mount Prophet Elias that we had passed through the day before.

And now we were approaching the ill-fated town of Zephyria, until fifty years ago the recognised capital of the island, and bearing the very ancient name by which Melos was once known. It is built at the end of a plain, along which a stagnant stream spreads itself out in winter, but which is in summer a waste of salt and pestilential exhalations. Nowonder Zephyria was unhealthy, a perfect hotbed of pestilence. The town must have been well and substantially built; some good stone houses and several churches are still standing, but all untenanted and empty. Here was the palace where the dukes of the Crispi family held their court, and now the outer streets are mere masses of ruins with the roofs tumbled in, a home for ravens and bats. A few houses are used as stores for those who farm the neighbouring fields 
and olive gardens. Only thirty years ago Ross found some miscrable people dwelling here. A few years before that Gouffier tells us how "these wretched inhabitants are yellow and swollen, their bellies enormous, their legs horribly swollen, permitting them with difficulty to drag themselves about amidst the ruins of their town.'

In the centre still stands the Church of St. Charàlambos, the saint whose special office it was to ward off the plague; and he still can be seen therein on a crumbling fresco in the form of a hideous wizard trampling disease under foot, with smoke issuing out of its mouth. It is rather a handsome Romanesque building, with two domes, in many parts roofless, and with long shreds of canvas hanging therefrom, on which once pictures had been painted. A tree is growing in the middle of the porch, a few tall palms, lots of olives and fig-trees mingle well with the ruins, and make them look highly picturesque. There is another church, that of the Virgin of the Basket, so called because tradition says a picture of the Virgin was found in a basket on the sea, which was being carried by the waves in the direction of Zephyria; from this church all the ornaments have been taken to adorn a like-named church which they have built down by the harbour of Adamanta, where many of the fugitives from Zephyria have established themselves.

Luckily for us, there were lots of people over in Zephyria that day who had come to pluck their olives; so we were able to get some wine from them and make friends with an old man, Peter Kromidonis, who remembered Zephyria as far back as I82I, when there were I,500 families living here, twenty-four churches, and no thought of abandoning the place. TVe sat down in an open space in front of the Church of St. Charalambos to refresh ourselves. 
'This,' said the old man, 'was the agore of our town. Yonder corner house was the café which I kept, and where my wife and nine children all died of the pestilence.' Poor old man! he seemed broken down with cares and ague, but it seemed a pleasure to him to tell us his reminiscences, so we encouraged him to go on.

'I was almost the last person to leave this town,' he continued. 'Up to ten years ago I kept on at the old café, but at last no one came near me. All my belongings were dead, so I thought I, too, would go, though I wished to leave my bones here ;' and he looked round affectionately at the deserted spot, and shortly afterwards, pointing to a piece of a Corinthian column in the middle of the square, he said, "That was where criminals were executed, and where innocent folks were stripped naked and flogged in the times of the Turkish Aga.'

'How was it the pestilence of Zephyria could not be checked ?' we asked.

'It all arose from the curse of a priest,' was his reply, as he solemnly crossed himself; and knowing the current belief in modern Greece that by his curse a priest can inflict any evil on the object of his denunciation, and that this belief gives them their firmest hold on the minds of the people, we asked for further particulars.

'The priest was really a bad man,' he said, crossing himself again, 'and was proved to have led an immoral life; so one day the people stoned him so that he had to hurry out of the town for his life in the direction of Kimolos. When still in sight of the city he took off his hat, lifted up his hands, and cursed it, praying that no stone should be left on the other. Shortly afterwards a plague broke out, and other diseases in turn, until the wretched survivors finally abandoned it altogether.' And as we heard this tale we thought of Chryses, the priest 
of Apollo at Tenedos praying for the pest to be used as an instrument for the recovery of his daughter.

'What happened to the priest ?' I asked.

'We don't know,' replied the old man, 'except from what the muleteer who accompanied him told us. He, when he saw the priest cursing, fell on his knees in terror, kissed the priest's feet, and implored not to be included in the curse, and the man, old Photis by name, died only four years ago at a ripe old age.'

Such is the belief in the power of a priest over disease. Likewise also, by the reading of prayers and exorcisms, they can check an epidemic just as easily as they can produce one; and this power, the people say, is delegated to them by the saints. St. Charàlambos and St. Besar:on give to the priests of their altar power over the plague; St. Mavra and St. Barbara do likewise to their priests during an epidemic of small-pox. And very often the derived power originates in the saint's name ; for instance, St. Jacob ("A yıos "A кovфos) heals deafness ( $\kappa o \hat{v} \phi o s$, deaf), St. Eleutherios gives relief to women in childbirth ( $\dot{\lambda} \varepsilon v \theta \varepsilon p i a$, freedom), St. Therapon of Lesbos cures $(\theta \varepsilon \rho a \pi \varepsilon v \varepsilon \varepsilon$ ) all manner of diseases. In this manner it will be easily realised how, in the Greek Church, different saints are considered as useful in different circumstances. A Greek becomes confidential to his saint, especially his name saint, whose picture is hung in the sanctuary in his bedroom. God to him is a mystery unapproachable; the saint it is who is supposed to act as mediator between God and man.

Curious beliefs about diseases are wildly current nowadays. Many believe that all maladies which attack the human frame are worms created by the wrath of God - a simple way of explaining the bacilli theory-or else they are devils which get into the body, and can only be 
cured by holy offices. Warts, for cxample, which some say have come from counting the stars, can be removed by a prayer to the Virgin in church and by rubbing them on the glass of the church windows.

As may naturally be supposed, unhealthy Melos is still full of people who are supposed to know charms for producing cures ( $\gamma \eta \tau \varepsilon v \tau a i)$. Knowing this, we put a question to our old friend as to what means they took to check the noisome pestilence which ruined Zephyria, and he told us some curious accounts of what they did here not so many years ago; and if they do not do these things now it is not for want of belief, but from the discouragement superstitions are now meeting with from the higher clergy.

About the time the pestilence was at its worst a cow had twin calves; this was looked upon as an omen not to be lightly passed over. So after forty days they yoked the calves and ploughed a portion of ground, in the middle of which they slaughtered the twins and distributed their flesh to the poor. But this sacrifice had no avail against the priestly imprecation. Then they decided on February Io, the day of St. Charàlam. bos, to 'boil the diseases,' that is to say, forty once married women wrote the names of a lot of illnesses on scraps of paper: these were boiled in a caldron with some money and a cock, but all of no avail. Yet another plan was resorted to: the forty women made a garment in one day, which they hung up in St. Charalambos' Church, and next day they cut it into bits, and distributed them to the poor; but the result was the same-the imprecation was triumphant.

Public charms and ceremonics such as these will probably never happen in Grecce again, but private acts of superstition are still numerous. We have scen how 
they exposed children supposed to be smitten by the Nereids on the altar of the Virgin's Church; they do exactly the same thing at the entrance of some catacombs which we were to visit presently in the vale of Klima, and with their incantations they believe that they can drive diseases into animals, trees, and cliffs ; for example, they believe that by leaving bits of the clothes of sick persons near stones the disease will be drawn into the stone. Round the neck of a fever-stricken patient they bind a string and then remove it and bind it round a tree, muttering mystic words at the same time, and suppose that they are binding the fever to the tree.

Euphemisms for diseases are as common in modern Greece as they were in ancient days. The small-pox is

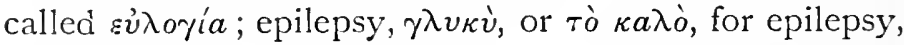
above all diseases, is looked upon as a mysterious sacred malady curable only by the priests. 'Is it not a devil,' they will say, 'which possesses the man? What can drugs avail in this case ?' And in this belief we are carried back to the days of Hippocrates ('De Morbo Sacro,' tom. 2), who laughed at the charlatans and magicians who pretended that epilepsy was a sacred malady curable only by priestcraft. Child's colic, again, they call

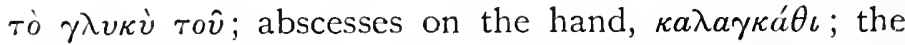
plague was known as the 'pardoned disease' ( $\dot{\eta} \sigma v \gamma-$

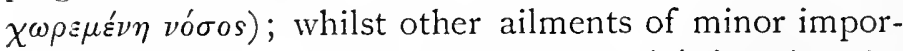
tance are known as the 'unintentional' ( $\left.\tau \grave{a} a \dot{a} \mu \varepsilon \lambda \varepsilon^{\prime} \tau \eta \tau a\right)$.

Our old friend, as we talked over the ills of Zephyria, grew warm on the subject of curses. 'Never shall I forget,' he said, ' the wretched Koubelos, who cursed himself whilst dying. His brother went to bed well, and next morning was found strangled, with black finger-marks on his neck. Even the prayers of the priests availed nothing in this case; everyone was in despair. At length 
an old man learned in magic advised them to open Koubelos' tomb, cut out his heart, burn it, and scatter the ashes to the winds, and then, after tying up the rest of the body in a sack, to sink it in the sea. Terrible was the sight on opening the grave: the corpse was black in the face, the finger-nails had grown a span long and were bathed in the blood of his victims! His hair was long, his eyes wild, and when they sank the body in the sea the disturbance was such that boats were nearly swamped. The plan adopted, however, was successful ; Koubelos never came again; but to this day Meliote mothers threaten their naughty children with a visit from Koubelos.'

It was quite time now to leave Zephyria, about which old Kromidonis had conjured up such horrible reminiscences. Though haunted by no vague dreads, yet I felt that this city of the dead, with its ruined houses and tottering churches, was about the last place in which I should care to spend the night; so we mounted our mules, and proceeded down the plain, full of stagnant water, to the seashore, visiting by the way a small house which is used as a salt factory, and a deep hole on the slope of a gentle eminence, where is an alum bath, and where, we were told, people go to cure the itch. ${ }^{1}$ The cave was very warm inside, and the recollection of the disease that here was cured made us as chary of stopping long as we once were in a church of St. Barbara where small-pox patients were said to be brought. Close to the sca are some singular caves; one in the shape of a large round room supported by a central column bears evidence of having been used as a church: a narrow passage inside connects it with the other side of the rock, and all about are evidences of tombs.

' In ancient times, says Pliny, the Mfeliote alum was most in repute after that of Egypt. 
Melos is an island productive of curiosities in nature. We have but to turn to the pages of Pliny to learn how esteemed all these things were in ancient times. There was the Meliote earth used for drawing, the pumice-stone used for polishing leather, and the above-mentioned alum.

That evening we slept at Adamantas, the village down by the port, about half an hour's ride from the Kastro, where all the business, little though it is, of modern Melos is carried on ; and here has been erected a new church to the honour of our lady of the basket, and from Zephyria they have brought a tempelon, five hundred years old, covered with lovely carving and symbolistic figures and all the sacred treasures, one of which is curious enough, being a piece of plank with a hole in it, and a picture painted on it to explain its meaning. A huge swordfish pierced a ship and dragged it all on one side, and in their extremity and dismay the sailors called on our lady of the basket for help, and she removed the obnoxious swordfish, and on their return to Melos they hung up the plank that the fish had pierced, thus painted, as an offering of thanks.

Aclamantas is an exceedingly uninteresting place to be obliged to stay at for three days whilst waiting for one of those wretched Greek steamers which ply between Crete and Syra, and stop at Melos on the way; and our discomfort was increased by the fact that the English squadron had touched at Melos only a few days before, and had seized upon all the provisions in the place; yet whilst waiting many points of interest offered themselves. We frequently visited Consul Brest, and had interesting conversations on Melos. Moreover he gave us an excellent pot of vegetable-marrow and almond jam to help us in our evil day ; but we looked grudgingly at some woodcock on his stairs, which we longed for, and could not get, as 
they were to be sent to Syra by the steamer ; and it was our one consolation in the eventual delay to learn that all these woodcock went bad and had to be thrown away.

We visited a collection of objects of antiquity which were for sale-not retail, but wholesale-a hopeless state of affairs with the lynx-eyed Greek Government officials to get past; we visited a priest who had brought his family from Crete; consisting of a fat wife and sixteen children, for poor Greek Papas, like poor English parsons, are a prolific race. ${ }^{1}$ He was anxious to sell some of the Church lace, of which we bought a little, doubting when he told us that it was for the benefit of the saint. We visited a washerwoman who was blcaching her clothes in a big basket by putting ashes from her wood fire on them as they soaked; and we visited two old women who were very busy preparing cotton for their loom.

Cotton is a great industry in Melos, for every garment and every article of houschold use is made at home. The old women were just now engaged in putting the raw material through a small hand instrument called $\mu a ́ r \gamma a \nu o s$, which turns two rollers different ways; this is to free it from the seed. The next process is to beat it

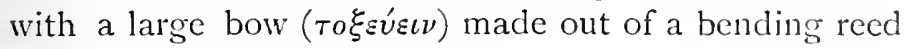
stretched tightly with a cord; and it requires to see one of these instruments to understand a Meliote riddle which had perplexed me sorely. 'My current is crooked, but my water runs straight.' Answer: 'A cotton-bcater.' Could anything at first sight appear more inexplicable?

After being loosely beaten by the string of this bow the particles of cotton which have now become detached are drawn together so as to form a loose rope, which is wound to the distaff, called рока, an Italian name, but the spindle is still known by the old name of a'тракто.

1 'In five months three children to the priest' is a proverb. 
Nothing is more picturesque than to see a Greek island woman spinning on her roof or on her balcony, occasionally letting her spindle whirl down into the street. When dyed to the required colours the woman then sets to work with her loom, a most complicated piece of machinery, which occupies a corner in every

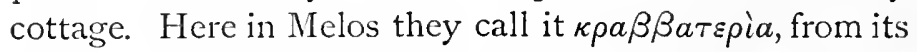

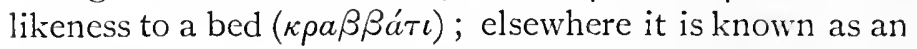

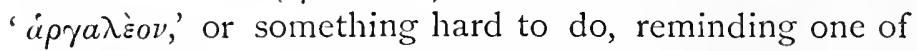
the old Homeric use of the word. Some of their productions in stripes and patterns of colour, yellow, red, green, and blue, are beautifully executed, but to earn anything by a loom is a thing exceedingly hard to do.

We rowed about the harbour in a boat, not daring to go far, for any moment the steamer might come; and we went to see the lazaretto of Melos, consisting of houses or holes excavated in the volcanic rock, like those of Santorin. One day we almost decided to give up waiting for the steamer, and take a caïque to Pholegandros, but the wind rose shortly before we started, and very thankful were we afterwards that we did not attempt anything so rash. And all this time we were lodged in a most humble house, in a veritable quiverful of children, but the people were kindly disposed, and did everything they could to amuse us in the evenings; they sang for us, they played the lyre for us; and very pretty were the words of some of their songs, though the music was to us monotonous, drawled out like that hideous music of the Eastern Church, so distasteful to a Western ear ; but the beautiful idea is present in every song. A tree withers, and why? Because two lovers plighted their faith beneath its branches, and that faith is broken. Again, like the flowers of the almond tree shone her face. Whosoever shall turn to look upon it will faint before her. 
Ideas such as these follow each other in rapid succession. I should like to have heard a lament over the dead at Melos, but was told to wait patiently till I got to Mykonos, where I should hear them best.

We heard, too, several of the fables with which old crones delight to amuse their grandchildren, $\pi a \rho a \mu v \dot{\theta} \iota a$ they call them, many of which remind one forcibly of Esop. In Amorgos I was told the fable of the struggrle of the sun and the wind to make a man take off his coat, and the ultimate victory of the sun; and from the remoteness of this island, and its little intercourse with the world, it is puzzling to divine how it got there. The following is a Meliote fable, as told by an old woman who was summoned for the purpose: it is a fair specimen of the kind.

'Good evening,' said she, coming in; ' many years to you;' and then she squatted down on her haunches and began :-

'Once upon a time an old woman went to gather sticks, that she might light a fire to warm herself; and to find the sticks she went to a waste bit of land, and at the end of this waste she saw a house; and as she was getting sticks it came on to rain, and for fear of getting wet the silly old thing went to the house, and on entering twelve handsome young Pallicars met her. "Good hour to you, my Pallicars," says she. "Same to you, old woman," they replied. "Why do you come here in such bad weather?" "Ah, my children! I am a poor old thing, and I came to gather a few sticks to keep out the cold, for my house, my children, is but a ruin; the roof is coming in, and the rain and the cold."

"Then one of the young men said to her, "Tell us now, widow, which of all the months is the worst." "Ah, my child!" answers the shrewd old woman, all the 
months are alike; none of them are bad, all of them have their good points and their bad." "But, my good widow," continued he, "how can January resemble May?" "My child," replied she, "if it did not rain, and there was no bad weather in January, then May would not have his flowers."

" "Have you got a sack with you?" they enquired, and the old woman gave them one she had with her for gathering grass for the cattle, and they filled it with florins, and she went home to her village. When her sister saw her she said, "Good gracious, sister! where did you get these florins from ?" and the old woman sat down and told her story; whereupon the sister on the next day took the biggest sack she could find, and made as if she would go to gather grass, and found the same house and the twelve Pallicars therein. She entered and greeted them and sat down. "How is it you are here, widow." "To gather sticks," she replied, "for now the wretched cold month of January is come, and I cannot keep my cottage warm."

" "A $A \mu \varepsilon$ !" tell us which of the months you like best," they said. "I like none of them," was her reply, "for some are so cold and bad, I do not know which is the best; perhaps February, for he has only twenty-eight or twenty-nine days, or March with the five winds, ${ }^{2}$ March the pole burner ${ }^{3}$ all the others are fire and heat." Then they said, "You have a sack, widow," which she joyfully gave to them, and they filled it full of snakes, vipers, scorpions, and all the evils of the black earth, and they gave it to her saying, "When you' get home

1 An expression in the islands for 'Come, now!' in which may be seen a trace of $\epsilon$ L̆ $\mu \alpha$, to go.

2 So called from his changeableness.

${ }^{s}$ So called because a peasant, not having laid in enough wood, thinking March would be warm, had to burn the poles to which his young trees were bound. 
shut your doors and windows, and open the sack carefully, for there is great treasure therein." So the old woman did so, and opened the sack as she had been told, when, lo! out came the scorpions and devoured the old woman because she had no control over her tongue. Be guided by me, and never trust to your own powers of speech.'

The moral of this fable is so essentially the giving of praise to where a Greek thinks praise is due, namely, to the astute flatterer who gets his gain by cunning and fair speeches.

At four o'clock, in the middle of a pouring night, the steamer's whistle was heard, and though we had to put into Siphnos for two days during a storm, for our steamer was unseaworthy, and though we arrived at Syra nearly a week behind our time, yet we had two consolations -first, that if we had started for Pholegandros in a caïque we should never have got there; and secondly, that the woodcock went bad.

\section{NOTE.}

\section{On the Antiquities of Mclos.}

I must now refer to the ruins that are left at Melos, of the city which once dared to resist the will of Athens, and which suffcred from that once proverbial 'Meliote starvation' ( $\lambda i \mu \rho s$ Mind trite saying amongst the Athenian wass because the Yeliotes dared to resist the power of Athens, and failed.

Can this one town of Melos have ever been of such importance? is the question at once suggested as you enter the narrow gorge of Klima, in which contracted defile all that was inhabited in ancient Melos was contained. It is a lovely position indeed, sheltered from all the biting winds, and overlooking the harbour and Mlount Prophet Elias; but could it ever have held a population of sufficient numbers to merit the place given to it in the pages of history ?

Herodotus tells us that the inhabitants of this little town, 
together with those of Seriphos and Siphnos, were the only islanders who refused to give earth and water to the heralds of Darius. It naturally occurs to one that perhaps these islands were too small and insignificant to have made it worth the heralds' while to go and collect those emblems of subjection.

When the Peloponnesian War broke out (43I B.C.) Thucydides tells us that Melos and Thera were the only islands which refused to acknowledge the supremacy of Athens. The Meliotes, as he explains, being a colony from Lacedamon, resented the lordship of their natural foe. Feeling the necessity of securing Melos, for its harbour, doubtless, and not wishing to leave an outpost for their enemies in their very camp, the Athenians, in 426 B.c., sent an armament of two thousand hoplites to subdue them, without avail ; however, shortly afterwards another armament seems to have been sent, with a more satisfactory result; so that in 425 B.C. we find Melos entered on the inscription discovered on the acropolis at Athens as contributing fifteen talents to the forced supply-that is to say, as much as the large islands of Naxos and Andros, but only half of what the rich Paros was forced to pay. Melos was, however, again refractory, and then followed the celebrated siege of this place, which Thucydides so graphically describes, and the final overthrow of the power of Melos by three thousand hoplites sent from Athens, arguing, as the remains prove, that the town of Melos cannot have been a place of great strength. The remains that have been found in the vale of Klima, nevertheless, clearly point to great wealth; the stately terraces of colossal stones which still adorn the hill slopes, the two theatres, and so forth, prove her advance in art to have surpassed that of the other islands of the Cycladic group except Paros and Delos.

As we descended from the Kastro to the vale of Klima, we could not help thinking that perhaps the position of Melos made it easier work for the three thousand hoplites than one imagined at first, for the town is hemmed in by mountains on two sides, and on the third by the sea ; and with our minds full of the terrible scenes which once had been enacted here we descended slowly into the vale of Klima. Our first visit was to a point which, from a church thereon, is called Prophet Elias, where are some granite pillars, two feet in diameter, the remains of a frieze and border. Perhaps this platform, standing a considerable height above the town, was the old acropolis of Melos. To the south-east of this hill are some seats made of tufa rock in the form of a semicircle. 
No doubt the remains of a small theatre, some steps further on, is the substratum of a temple, with remains of large Corinthian cornice pieces of bluish marble, and the centre piece of a frontor with a round Argolis shield in bas-relief upon it. These ruins the inhabitants call the palace of the king of Melos, as elsewhere colossal walls go by the name of the dragon's house, for every ruin must of necessity have a legend attached. Here, too, during the late war a statue of Æsculapius was found. Evidently in ancient times, as inscriptions prove, Esculapius and Hygeia were worshipped in Melos, as now are St. Charàlambos and other saints considered beneficial to an unhealthy spot.

A little lower down are the remains of the greater theatre, which the Crown Prince of Bavaria bought in 1836 to protect them from obliteration; yet, notwithstanding, stones are rolling down over it and constantly chipping off bits of the marble seats, seven rows of which are still perfect; but it is easy still to see how much higher it formerly was. It would appear that it was never entirely finished, for the tenons which have been used for placing the marble are not moved; perhaps the destruction of Melos, incident on the Athenian War, came before the completion of the work, for the construction of the theatre is of the best Greek period, and after the destruction of the town Melos was never in the least flourishing again till the Roman days.

About two hundred yards from the theatre is the spot where the Venus of Melos was found. The discovery occurred in the following manner :-A peasant, in February I 820, wished to extend a little terrace field he had here by pulling down a heap of stones, and in doing so discovered a scrt of mound, and having cleared the place he found therein in confusion three statues of Hermes, bits of marble, a plinth with inscriptions, and the now celebrated statue of Aphrodite in several pieces. Mr. Brest at once bargained for this treasure, but the peasant asked more than Mr. Brest wished to give, so he sent off to the French ambassador at Constantinople for advice and money; but before the messenger returned the Meliote authorities began to suspect its value, and determined to make a present of it to a Greek hospodar in favour with the Sultan. When the messenger returned, with full authority from the French ambassador to purchase at once, he found the object of his quest in a boat on its way to a ship carrying the Turkish ensign. Owing to great liberality, and the superhuman exertions of Mr. Brest, the priceless statue was secured for the Lourre and France. 
Evidently the Meliotes had purposely buried their statues, and the knowledge of this has made the vale of Klima the Eldorado of collectors ever since. Some years ago M. Lambratsis, an antiquarian at Athens, bought a bit of ground on the flat space down by the harbour with the intention of digging for hidden treasures. At length, disgusted with finding nothing, he sold it for a trifle to his nephew, who proposed to plant it with oranges. In digging for this purpose he found a headless horseman of the Roman period, and on digging further he came upon the statue of Poseidon, which graces the Athenian Museum to-day.

The Roman horseman, however, still stands where it was, half embedded in the soil near the water's edge ; but Greeks despise anything of so recent a date, and the carcasses of horse and rider, though of good workmanship, are allowed to cumber the ground as rubbish.

This little flat space is a mass of ruins, many pieces of which have served to build a cottage, a mill, and a reservoir; into the sea project the massive remains of a wall of the Roman period, and all along the coast are remnants of the past.

On our return up the hill towards Plaka we visited the catacombs of Melos. The whole hillside is covered with pagan tombs, but the vast galleries of the Christian necropolis cut in the tufa rock: are the most curious. There are four entrances and five galleries with annexes, the first three of which present unmistakable signs of Christianity from the inscriptions; in one we saw Constantine's monogram, but in the other two galleries there is nothing but the resemblance to the others to tell us that they, too, contain Christian tombs. Besides these galleries, now cleared out, there are evidences of entrances to other catacombs still closed up.

The form of the tombs is distinctly borrowed from the pagan idea, having curved and vaulted roofs ; many of them have plaster on still, and at the end of the arcosolizm appears the funereal inscription, some of the letters of which appear to have been only plainly cut, whilst others are painted red, and the lines have been separated from one another by stripes of red. One inscription is in a red cartouche, and has red and green bands like those in Roman arcosolia; sometimes an arcosolium is decorated with roughly designed flowers and the monogram $X$, but they are now very difficult to trace. In the arcosolia are niches for lamps; there are only slight traces of loculi, two side by side. At the end of one gallery are two arcosolia, destined each for

$o$ persons, and 
tombs behind. At a rough calculation there must have been about one thousand five hundred buried in the part at present open. so probably, as Melos never rose to any very great importance during the later Roman period, these tombs, which evidently belonged to the richer class, were excavated during a considerable term of years, though throughout the architecture is the same.

These tombs are looked upon with extreme awe by the Meliotes of to-day as the habitations of kindly disposed spirits; and here it is, as I alluded to above, that the superstitious mothers will expose their sickly infants to recover from the supposed stroke of a Nereid; and down in the valley of Klima there are said to exist what they call 'midday gilosts,' and it is deemed rash to approach the ruins there at midday or midnight, especially during the dog days, for fear of being seized by them. This is an ancient prejudice, and the idea is carried still further: a man must stop playing his lyre or his pan-pipe at midday, and he had better not lie down to rest at that hour under a suspected tree, or he will insult the nymph thereof, and be punished with madness. 


\section{CHAPTER V.}

ANAPHI.

THIs is the extreme south-eastern point of the Cyclades, the island of the rising sun, as its name implies ('Avá $\phi \eta$ ), so called from its mythical association with the sun god Apollo Eglites. In the whole of the Cycladic and Sporadic groups there exists no island so remote in its solitude as Anaphi. Though included in the former group, because it now belongs to Greece, Anaphi has no business to belong to the Cyclades, for in no sense of the word can it be said to be encircling Delos. It is a mere speck in the waves, in the direction of Rhodes or Crete, where no one ever goes, and where the 1,000 inhabitants of the one village thereon are as isolated as if they dwelt in an archipelago in the Pacific.

We left Santorin at 9.30 on a lovely January day in a tricandera, with every prospect of easily accomplishing our sixteen miles' sail in a few hours. It was a day which shows the point of the Greek proverb, that 'if January could, he would be a summer month.' Apollo blazed upon us as we sailed sluggishly out of the port and along the volcanic coast of Santorin, so that we had time to admire and grow weary in turns of each strange headland -one black, one green, one red-fantastic volcanic rocks, and we longed in vain for a breeze. In the blue distance the peaks of Anaphi looked for ever the same - the usual 
Mount Prophet Elias, the rocky Mount of Kalamiotissa, below which the temple of the sun god still lies, and then we thought how completely the cloak of Apollo has fallen on Prophet Elias in modern days. Every highest hill in every island is as of old dedicated to Elias; it is an obvious transition. "H $\lambda$ เos (the sun) at once suggested Elias to the easily accommodating divines of the new religion, and to all intents and purposes the prophet supplies the place of the sun god of antiquity. He has power over rain; in times of drought people assemble in crowds in his church to pray for rain; and in this he has the attribute of another branch of the sun god, ${ }^{\prime} \mu \beta \rho \iota s$, or

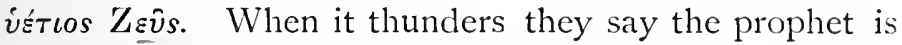
driving in his chariot in pursuit of demons. A curious MS. in a convent at Lesbos illustrates both these ideas; it is in the shape of a dialogue, and the following is an extract :-

Epiphany: Is it true that the prophet Elias is in the chariot of thunder and lightning, and pursues the dragon?

Andreas: Far from it; this is great folly, and only an idle report, which men have set up out of their own ignorance; as also is the story that Christ made sparrows out of clay before the Jews, and when He threw them into the air they flew away, and that He turned snow into flour. These are also false like the other, and such as the heretics unreasonably preach; for the prophet has not gone up to heaven, nor does he sit on a chariot; but he has poiver to ask God for rain, so that in a time of drought he can give moisture to the earth.

In classical mythology, it will be remembered, the attifudes of the sun god were divided amongst many; the oneness of sun worship is of an earlier date.

Pretty allusions to the Dawn are frequent now in popular verse; it is the Virgin who has supplied the 
place of Eos, she is the mother of the Sun ; she opens the gates of the cast, through which her son can pass; and about the all-glorious sun a Greek peasant cannot say too much. He is the pattern of perfect beauty; 'beautiful as the sun' is a constant expression to describe the beauty of a girl. I have heard an island mother say, 'Perhaps the sun will carry a message for me to my child,' when she was speaking of her daughter in service somewhere on the mainland. It is but the same idea that Sophocles puts into the mouth of the dying Ajax, who appeals to the heavenly body to tell his fate to his old father and his sorrowing spouse.

The belief that the sun is in danger when obscured by an eclipse is somewhat exploded now, yet there are those living who remember when the people used to come out with brass kettles to drive away the evil demons, which were threatening the life-giving sun, traces of which custom still survive in songs.

Meanwhile the sun pursued his course steadily, and our sailors measured the light constantly from the sun to the horizon with their fingers. Each finger's breadth represents a quarter of an hour's daylight; an inch of daylight, as the expression goes; but the sun set before we were clear of the last cape of Santorin, where we had elected to pass the night had not a breeze sprung up after sunset, which promised to help us on our course.

At length, about two o'clock in the night, after a sail of sixtcen hours, we landed on Anaphi. Not, alas! near the one town, but on the north side of the island, two hours away. Not till then did we rcalise the benefit of those churches, which are dotted everywherc over the islands for benighted wayfarers like ourselves. Our only chance of a little rest lay in entering one of them. It was, of course, only twelve feet by eight; it had a mud foor 
and no seats ; we had to be content with stones for pillows and our rugs for bedclothes, but it was a warm and lovely night, so we were content.

Early next morning we arose, and despatched our manservant, who was a native of this island, to the town to get us mules, and we were left to puzzle our brains as to how to get any breakfast, for the long day in the boat had exhausted our provisions. We got together some brushwood and lighted a fire, in the embers of which we cooked some bacon, which we ate with hard bread and washed down with water ; but, as they say in Greece, 'hunger has no eyes, and if it had it would not use them.'

An uninteresting ride of two hours across a hilly, brown, and apparently barren country brought us to the Chora. On the side along which we passed we had no difficulty in deciding that Anaphi was barren even for one of the Cyclades; and Tournefort's naïve remark when he visited it in 1700 will apply still, that it has not wood enough to cook the partridges which abound. In red-legged partridges Anaphi certainly does abound. Coveys of partridges and lots of wild pigeons we stirred up at every turn. A story is current that a brace of partridges was brought over from Astypalæa to Anaphi, and became so prolific that the bird has become a plague. This popular story coincides curiously with an account Athanasius gives us of the quantities of partridges in Anaphi, where he said that the inhabitants were in danger of having to quit the island from their abundance. It is just possible that the stories are identical, and that it has survived for centuries.

There are no serpents in Anaphi, only green lizards. It is curious in almost every island the reptiles are different. In Siphnos they have very poisonous snakes; 
in Keos they have scorpions; in Antiparos they have only little adders; whereas on the adjoining Paros they have very huge and poisonous snakes. Anaphi is blessed in this respect, if not in trees and verdure.

The town, as usual, crowns a conical hill, and on the vantage ground afforded by two windmills we saw, when fully a mile away, all the population of the place straining their eyes to get a glimpse at the strange foreigners who had come to visit their shores. This was not to be wondered at, for in winter time the Anaphiotes must be very dull, for at Santorin they had taken the opportunity to give us the post for Anaphi, a small packet of a dozen letters, nearly all of which were from the Government to the demarch, and it was the first post they had had for two months.

- Often we have no communication with the outer world for three months in winter time,' replied the demarch in answer to my expressions of surprise; "for Anaphi has no harbour whatsoever, and the small cleft where the fishermen draw up their boats is exposed to the full fury of a southern gale. Those who come here are often obliged to stay longer than they expect,' he concluded with a hospitable ring in his voice. We smiled in return, but felt apprehensive all the same, for we did not wish our stay here to be too protracted.

The great name in the island is Chalaris. The demarch's name is Chalaris, and to him we were introduced as soon as we had taken possession of an empty house which was placed at our disposal during our stay by the brother of our servant. Shortly afterwards another Chalaris was brought in, a deaf, shrivelled-up old man of ninety, who had assisted Ross to dig in 1836 , and was prepared to tell us of all the antiquities in the place. No sooner was he deposited on the sofa than he asked, "What 
men are these?' 'English,' was the reply ("A $\gamma \gamma \lambda$ ¿ $)$. 'Wild men (ärpo )?' said he with surprise. 'No, I will never believe that they are wild men ;' whereat there was a great laugh at our expense, and we soon became very friendly. We liked the Anaphiotes extremely; they were so cheery and simple, and, furthermore, a strikingly handsome set of people. There was the old grandmother dressed in black, her head almost buried in a black handkerchief, who sat neglected, and like a bundle of rugs, in a corner; then there was a portly lady, wife to our host, who was absent, and her beautiful daughter Eutimia, whose dark hair, pencilled eyebrows, classic profile, and rich complexion made her a picture even in her working clothes; but when that evening, at our request, she donned one of the old Anaphiote costumes her appearance was magnificent : it consisted of a violet silk- brocade skirt, green velvet bodice, gold embroidered stomacher, and a short pink satin jacket, edged round the cuffs and down the front with pink fur. The headdress somewhat resembled the pina of Siphnos, but is here called 'the circle'

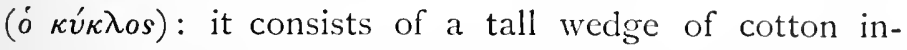
side, over which Oriental handkerchiefs are gracefully arranged, so that the ends hang down over the shoulders. During the last few years this style of dress has been entirely abandoned; those who wore it were laughed at ; and Eutimia that evening came in for a good share of ridicule, but I think a consciousness of our approval more than made up for this.

As it is at present, the dress of the women of Anaphi is more than usually sombre. After the death of a near relative they wear black for an immense time: girls after the loss of a parent do not go out of mourning till they are married; widows and elderly people never dream of removing their black. Knitting seems to be their 
great industry; they sit at their doors knitting and gossiping hard, with their thread fastened round a button sewn to their dress at the shoulder for this purpose.

After a rest and a repast, at which partridges formed a prominent feature, we issued forth, accompanied by the two Chalaris, to take stock of Anaphi. Chalaris the elder insisted on our first visiting his house, which consists of one room, and is furnished with a bed, sofa, chair, table, and endless archæological trophies scattered around. With pride he pointed out the various objects he had collected-the torso of a statue let in over his door, an inscription let into his well before the houseand finally he pointed to a large slab of polished marble leaning against the wall.

'That is to be my tombstone,' said the old man with pride. 'I have just got it, and I am going to begin at once to carve the inscription on it.'

'He is very proud of himself,' put in his kinsman, the demarch, in a low voice. 'He is determined not to be buried in a cemetery amongst us, with just a stick to mark the place; he has chosen his own tomb, and, depend upon it, he will carve something extravagantly laudatory on that slab.'

'I am not dead yet,' put in the old man rather testily, for he did not like his kinsman's cynical face and subdued voice; 'and, if you like, I will take you to see the ruins to-morrow,' he said, turning towards us ; but knowing this to be impossible, for the old man was already worn out by the excitement of our company, we thanked him and bade him adieu, and continued our walk with the demarch.

'Anaphi is one of the healthiest of the Cyclades,' remarked our friend with pride ; 'it is by no means rare for people to reach a great age, and we have no doctor in the place.' 
'Then what do you do when ill ?' I enquired.

'Oh! we understand a little about medicines ourselves. I keep a few drugs, which I dispense at the demarcheion; but our remedies are chiefly the herbs which grow on our mountains.'

Certainly the lot of the thousand Anaphiotes is an enviable one. No steamer, rarely any letters, splendid air, no doctors. No wonder they live to ninety! The town, too, is exceptionally clean for an island one; the houses have all vaulted roofs, like those of Santorin, and consist for the most part of only one long narrow room, a door into the street, a window on each side of the door, and one above. They are whitcwashed within and without, and each house has its round vaulted stove, about five yards from the house, where all the things that cannot be cooked are taken on a small brazier. The chief cooking utensil of an Anaphiote cottage is a long pole, at the end of which is attached an oval board, on which they place anything they wish to cook, to shove it into the oven: this pole is called Lazarus, and the answer to a quaint Anaphiote riddle, 'Long, long as Lazarus with a cake on his head,' is this pole. For a long time the reason for this simile baffled me, but at last I discovered that the popular idea of Lazarus when he was raised from the dead is that he was an abnormally tall, thin man with a round, flat head.

Anaphi is celebrated for good bread, and when they have a baking they do it with a vengeance, for they bake IoO to I50 okes for one family at a time, and what they cannot eat fresh they dry, and call biscuit, which it is necessary to soak in water or coffee before eating. A good deal of this hard bread they send out of the island.

Everything is done at home at Anaphi ; their wind- 
mills grind their corn, their fields produce a sufficiency of grain, their looms make all the materials for their clothes, their hill slopes produce excellent grapes. 'If the rest of the world was to disappear,' said the demarch, 'and Anaphi alone be left, the only thing we should miss would be tobacco;' and relative to the subject of tobacco I asked him if he approved of the new tax the Greek Government had recently put on cigarette papers.

'Bah!' exclaimed he with a wink, 'the tax has not yet reached Anaphi;' and the chief functionary of the law chuckled to himself as he rolled a cigarette in smuggled paper. 'I suppose,' continued I to change the subject, "that the war of independence and the liberties of Greece did not affect you much ?'

'We are Greeks,' he said indignantly, 'and we sent our two caïques full of men to take part in the war.'

On the top of the conical hill is a medirval citadel. William Crispi, brother of James XII., Duke of Naxos, got Anaphi as an appanage, and here he built the castle which we now saw. Eventually his elder brother died, and he in his turn became duke of Naxos, and left his daughter Florence as lady of Anaphi. After her death the Turks seized it, and under the Turks the Anaphiotes had a very easy time of it. In I700 they paid a fine of 500 crowns for all their rights, and after that no Turk ever came near them, for their annual tribute was collected by a native epitropos, who once a year betook himself to Cape Drio, on Paros, when he handed it over to the Kapitan Pasha; if this tribute was paid regularly the islanders had no cause to fear a visit from the Turks.

Catherine II. of Russia was the first to break the peace of these outlying islands in 1770 by inciting them 
to rebel. An old tradition existing in Greece, that the Turks would be destroyed by a fair race, favoured her scheme, and, of course, the bond of religion was a great one, and for nearly five years, under Prince Orloff, the Russians ruled in the Cyclades.

Next morning, accompanied by Demarch Chalaris, we set off on mules to visit the old Hellenic town of Anaphi. It was a threatening morning, and showery at first, and Chalaris the younger did not seem at all inclined to start; however we assured him that we often went out in the rain in England, so he laughed at us, and referred to his kinsman's mistake about wild men, and finally consented to be one for once in his life. On our way a glorious rainbow appeared bcfore us, and the demarch told us how the peasants of Anaphi know how to foretell the crops by the colours of the rainbow. If red prevails in it the crop of grapes will be abundant; if green, that of the olive; if yellow, that of corn. 'A rainbow in the morning,' he added, 'denotes luck; in the evening, woe;' so we felt to-day that the omen was in our favour.

'The nun's girdle' as they call the rainbow in these parts, strongly recalls the ancient myth about the virgin goddess Iris, and the idea that God sends it to show where a treasure is buried reminds one of the belief that Iris was Jove's messenger from heaven to earth.

It hailed pretty sharply now and again, or, as they will persist in saying, ' it snowed.' Everything, including even cold rain, is called snow in these islands. "White as an egg it was, round as a peppercorn, but by St. George it was neither of them,' is an Anaphiote riddle, to which the answer is, not hail, but snow.

The old town of Anaphi had a very commanding position, and from the remains we saw it appears to 
have once been a very strong rich city, amongst the finest in the Cyclades. On the summit of the ancient acropolis are the remains of a temple. Some portions of the cella are still to be seen. From an inscription which was found on a votive statue we learn that there was once here another temple to Pythian Apollo combined with Artemis Soteira. All around are colossal walls, the foundations of houses, cisterns, and quantities of headless statues. On the slope of the hill between the town and the harbour was the necropolis of ancient Anaphi, which has contributed rich 'finds' to excarators -gold earrings, bracelets, precious stones, and things betokening a rich community. Close to a little church we came across two lovely marble sarcophagi ; on one of these was a beautifully executed representation of children bringing sacrifices to Bacchus, one of whom is in a well-portrayed state of intoxication, as he places something on the altar; on the other side are Bellerophon and Pegasus; and on the two narrow sides Sphinxes. The other sarcophagus, which appears to have been even richer in execution, is smashed up and built into walls.

An old woman who was looking after her crops here gave us a fig, curiously moulded in a sort of clay, which she had found in one of these tombs; and we saw two round balls, of the same material, with inscriptions on them, which had likewise been found in tombs.

We then made our way down to the shore, where was the ancient port, and where we saw traces of houses, a mole, and steps going down into the sea. This spot still

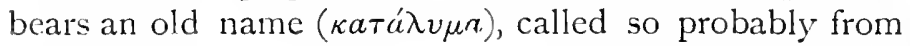
the fact of its containing inns or halting places for travellers: it is an exceedingly rare classical word, and entirely unknown in modern Greek. Here, too, is a lime- 
kiln, the invariable destroyer of marble remains. Let us hope that this barbarous custom of converting marble friezes and statues into lime will soon be heard of no more in Greece.

Down by the shore, with a deliciously warm sun to dry the effects of our early morning wetting, we sat down to our midday repast. Demarch Chalaris waxed gay and talkative as he quaffed the good wine of his island; and he pressed us to eat an abominable black and green sausage of bacon and garlic, and seemed disappointed at our refusal; so he pulled a long face by way of revenge at some chocolate we gave him, called it horrid stuff, and said he would keep it till he got home to make coffee of, as it was raw.

On our way home we passed through some of the demarch's own fields, where they were busy ploughing. A plough in these parts is an exceedingly primitive article, somewhat similar to those which Homer would have seen if he had not been blind. The chief ingredient in a plough, and a rarity in Anaphi, is a tree with a trunk and two branches; one branch serves as a tail and the other has a bit of iron fixed to it, and penetrates the ground; the trunk is the pole. Sometimes there are slight improvements on this, but not often. The beauty of this plough is that it is so light that the farmer can carry it over his shoulders as he drives his bullocks before him ; they never care about making deep furrows, and they never make straight ones. Often the farmer begins by ploughing out a circle for his morning's work; this he goes round and round and across in a careless manner until his task is over.

We kept along by the shore on our way home, and the demarch told us much about ihe great quantity of sea demons ( $\theta a \lambda a \sigma \sigma a \mu c i \chi \iota a \iota)$ that they have at Anaphi. 
From his description we gathered that they were a species of Nereid of the sea who are for ever fighting with the Nereids of the land. One day a shipowner who put into Anaphi with a cargo of cotton went up to the town to see about his affairs, and in returning to the port he there encountered a demon, ten times bigger than himself, which chased him down the hill and then disappeared in the waves. Such stories remind one of the adventures of Ulysses. Another species of hobgoblin occurs in Anaphi, bearing the ancient name and attributes: they are the Lamiæ, evil-working women who live in desert places, ill-formed like their ancestors, daughters of Belus and Sibyl. Utterly unfit are they for household duties, for they cannot sweep; so an untidy woman to-day is

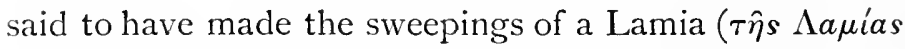
$\tau \grave{a} \sigma a \rho \dot{a} \mu a \tau a)$; they cannot bake-a great offence, indeed, in Anaphi-for they put bread into the oven before heating it; they have dogs and mules, but give bones to their mules and straw to their dngs. They are very gluttonous, so that in Byzantine and modern Greek the verb $\lambda a \mu \iota \omega \nu \omega$ is used to express over-eating. They have a special predilection for baby's flesh, and a Greek mother of to-day will frighten her child by saying that a Lamia will come if it is naughty, just as was said to naughty children in ancient days; for the legend used to run that Zeus loved Lamia too well, untidy though she was, and Hera out of jealousy killed her children; whereat Lamia was so grieved that she took to eating the children of others.

Some Lamiæ are like Sirens, and by taking the form of lovely nymphs beguile men to their destruction; for example, an ecclesiastical legend, savouring strongly of Boccaccio, tells us how a Lamia charmed a monk as he sat by the side of a lake one evening. Dawn came, and 
the monk was seen no more; but some children swore to having seen his hoary beard floating in the waters of the lake.

That evening after our dinner Eutimia and her mother determined that we should see all that was best of Anaphiote society, and invited their friends and acquaintances to a ball : this was very pleasing to us, as now we knew we should see the manners and customs of their private life to perfection. Dancing is a passion amongst them, and one can easily imagine their love for it when one thinks how shut off they are from all the pleasures of the outer world. As for the syrtos, they dance it admirably and in a most pathetic manner: the leader bends on his knee in prayer to his adored one, he stretches out his hands to heaven to supplicate the intervention of divine power on his behalf. Dancing, in short, as in ancient times, is considered as a means by which to express feeling by the evolution of hands and legs. The social dance, as we know it in Western Europe, is unknown.

They have several local dances in Anaphi; the $\sigma \dot{\sigma} \sigma \tau a$, danced only by men, is curious : they stand, as in the syrtos, in a semicircle, with their hands on each other's shoulders, and then they begin to move slowly backwards and forwards, quickening their steps as they go, until they end in an exceedingly rapid motion. Demarch Chalaris joined in this, with the result that, being nolonger young, he got much exhausted, and excused himself for the rest of the evening by saying that he had too young a heart in too old a body.

Another pretty dance is the moloritis; Eutimia and another girl danced it with two men: first they danced hand in hand, like the lady's chain in a quadrille, then they danced separately, the women, of course, 
demurely, whilst the men performed acrobatic feats, as

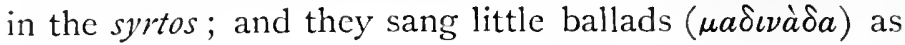
they danced.

After a while a rough, coarse-looking shepherd came in, and his adrent was greeted with great joy, for he was reckoned the best singer in Anaphi. Poor man! he was very shy, and they had to ply him with constant bumpers, for ' Andronico never can sing till he is drunk,' they said, quite as a matter of course. At last Andronico gathered himself together for a song, and a boy played a goatskin sabouna-that wretched Grecian substitute for the bagpipe-by way of accompaniment. When thoroughly prepared to begin Andronico shut his eyes with determination and threw back his head, shaking as he did so his long, shaggy, unkempt locks and his whole body. Then he opened his mouth wide, and thereout proceeded the most melancholy, deep-noted, timeless utterances that ever could be called a song.

The words of this song Eutimia kindly copied for me next morning, and as they struck me as a production of a curious nature I will append a literal translation:- -

Your figure is a lemon tree,

Its branches are your hair;

Joy to the youth who climbs

To pluck the fruit so fair.

Black garments, such as now you wear,

Myself I will cast off,

That I may clothe you all in gold,

And take you as my love.

Ah me! Ah me!

Now withered is that lemon tree,

And 1 am full of woe.

Come let us walk, and let us grieve

Together as we go. 
And I will tell, and you will talk,

Will tell, will talk together

Anent the woes that blight our hearts,

That they may wither, wither!

Andronico's song was covered with applause, and more wine was administered, which resulted in his consenting to dance in a musical syrtos, of which he was to take the lead. First, he cast off his shoes, by way of preparation; such shoes as peasants in Anaphi wear. being made of thick pig's skin, with the bristles left on : they are excellent for climbing rocks and keeping out the wet, but not for dancing: and now he sang more wildly than before and danced more vigorously than anyone clse. The verses of the song he sang were answered by the young man who danced at the other end of the wavy line. But as the dance went on Andronico forgot to sing; he got wilder and wilder in his evolutions, until at length his movements were scarcely creditable, and he was conducted home.

'Andronico,' said Eutimia smiling, 'never can do anything till he is drunk.'

The following day was devoted to a visit to the monastery of Kalamiotissa, built out of what is left of the old temple of Apollo Aglites. The demarch accompanied us as before, but this time we went by boat, for the distance on muleback would be weary. One of our men took some dynamite with him, and though the representative of the law in Anaphi was with us he winked at the boatmen fishing in this forbidden manner, and I thought again of the cigarette papers.

The legend in olden times ran that Apollo raised up an island out of the sea to succour the heroes on their return from Colchis in search of the golden fleece; and this island was Anaphi. In return for this benefit a 
gorgeous temple was built to Apollo Aglites on a narrow tongue of land which unites the mainland of Anaphi to a gigantic mountain rock which stands boldly out into the sea, now called Mount Kalamos. All the way from the old town to the temple, some two miles distant, can be seen traces of the old sacred way, the pavement of which is left in parts, and is worn with chariot wheels; and on either side of the way are frequent tombs, as on the road between Athens and Eleusis.

Three monks only now live at the monastery of Kalamiotissa, the only one in Anaphi; and the day before our visit the superior had died, and they had had splendid lamentations over his body, at which we regretted not to have been present. The monastery now belongs to one in Santorin, and is built on the gigantic foundation walls which supported the temple of Apollo, one stone of which I measured, and found it to be two yards twenty-eight inches long by two and a half feet high: these stones are of a coarse sort of marble which is found close by.

The pronas of the temple is standing as it was, and is now used by the monks as a store, where they keep their grain and instruments of husbandry; the peribolos of the temple is worked into the present church and other cloister buildings; and the cella is the present refectory. In every direction are to be seen inscriptions let into the walls. There are two platforms, which apparently seem to have been used for buildings, and all round are traces of foundations; and it would appear from the inscriptions that this ground was once covered with temples, the principal one being dedicated to Apollo Aglites, another to Aphrodite, another to Esculapius, \&c.

Before returning to our boat we were taken to sec 
an inscription in a ruined house which gave a catalogue of the consuls to the deme of Anaphi in letters of Attic type. There are enumerated on this stone seven consuls from different parts of Greece resident at Anaphi-one from Thessaly, others from Mykonos, Cnidos, Paros, Chios, Lacedæmon, and Siphnos - which fact points to the importance of Anaphi at that period.

The monks of Kalamiotissa received us well, and offered us the best of their cellar and larder; but they were depressed, poor men, at the recent loss of their superior; so we burdened them with as little of our company as possible, and returned to the town as soon as our investigations were concluded.

We had intended to spend a few more days at Anaphi; our quarters were comfortable, our friends genial and quaint; but on the following morning there was a breeze, which promised to carry us quickly back to Santorin; so, deeming it prudent to secure a passage whilst we could, we bid a reluctant farewell to the Anaphiotes. Eutimia and several others accompanied us to our boat, and in four hours we were once more under lee of Thera. 


\section{CHAPTER VI.}

\section{SANTORIN (THERA).}

\section{The Volcano.}

BEFORE landing on Santorin and mixing ourselves with its people, we must consider for a brief space the particular feature of the island, namely, the volcano. ' The Hephastus, as they call it, has made of Santorin one of the most terrible spots in the world, and has had a powerful influence on the inhabitants.

Taken from a general point of view this volcanic cluster is round, and in ancient times was called $\Sigma \tau$ soy $\gamma \dot{\nu} \lambda \eta$ (round). The island of Santorin proper is on the outer circle, eighteen miles from point to point, and twelve on the inner circle, and it is somewhat like a horseshoe; the remainder of the circle is made up by two islands, Therasia and Aspronisi, and three channels, by which the central basin or harbour is entered. All round this central basin, which is the cone of the volcano, the island presents a frontage of precipitous volcanic cliffs, from 500 to I,OOO feet in height, all in strata of twisted and contorted volcanic lava, red, green, and black, giving the whole place a hideous yet fascinating appearance.

1 Excellent authorities for the volcanic eruptions of Santorin are written ly Pêques, Fouqué, and Dekigalla, who were present at the last one in IS60. 
In the centre of this large circle, which is from east to west four miles, and from north to south six miles in diameter, lie the active centres of the volcano, a cluster of three hideous islands, steaming with smoke and streaked with sulphur, which have appeared at various dates out of the bowels of this circle. They are called respectively Old, Little, and New Burnt Island ( $\pi a \lambda a \iota \dot{a}, \mu \iota \kappa \rho \grave{a}, \nu \varepsilon \grave{a}$ $\kappa a \mu \mu \varepsilon \nu \eta)$. The depth of the water in this central basin is immense; the cliffs go down straight into it, so that there is no possible anchorage, and vessels have to be tethered, so to speak, to the shore. From the summit of these cliffs the land gently slopes down to the sea-level on the outer side; the widest part of the island is scarcely three miles, the narrowest considerably under a mile-at each end of the horseshoe of Santorin are the cliffs of Akroteri and Epanomerià.

There is only another feature which has to be considered at the south-east corner of the island of Santorin. There rises a mountain, Mesa Bounò by name, about I,500 feet above the sea. This mountain and its spurs are not of the volcanic formation of the rest of the island, but consist of a rock formation common to most of the Cyclades. It is evident that this Mesa Bounò was an island, around which the crater has shed its shower of pumice. Moreover, in the midst of the sloping plain rises up a single rock, Ioo feet high, called the Monolithos : this is of the same formation as Mesa Bounò, and presumably was once a rock in the sea.

In this otherwise flat surface of Santorin occur deep chasms, formed by torrents, as their local name of

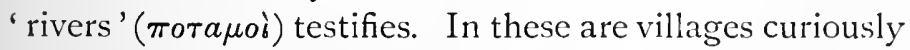
hidden, which we shall presently visit. The soil is very light and thin, consisting chiefly of crumbled pumice: it seems favourable for the growth of nothing save the 
grape: in fact, the slopes of Santorin form one vast vineyard. The roads are horribly disagreeable to walk on, being like the sand on the shore which the tide does not regularly reach.

Concerning the earliest eruptions of this volcano we have no data to go upon. The island has at various times and seasons sprung from the submerged volcano, and has been formed by multiplied eruptions. Herodotus is the earliest author who mentions it, and he tells us that in mythical times it had seven towns or villages, and that the earliest inhabitants were Phœnicians; and then came Membliaros, who colonised the island. In fact, Herodotus professes to give us the earliest traditions of the place, but never alludes to a vast eruption which covered the whole of the island with thirty feet of pumice and buried whole villages as completely as Vesuvius buried Herculaneum and Pompeii. A few years ago workmen employed in the quarry of pumice stone to the south of Therasia came across one of these buried villages, ${ }^{1}$ and two years ago, near the promontory of Akroteri, another village was discovered, which seems to be more recent than that on Therasia, and not to have been buried so deep; also traces of iron implements were found. All monuments of an historical Greek period are above this layer of pumice, and from this we argue that before the island received its present level there must have been frequent and terrible eruptions, burying from time to time the whole place in pumice; and all this must have occurred bcfore the colonisation of Membliaros, for from this date onwards we have a consecutive account of the inhabitants, and no mention of any eruption till the first historical one, which occurred somewhere about I 98 B.C., and which caused Old Burnt Island to come forth out of the sea, in the centre of the circular basin.

1 Vide note appended to this chapter. 
Apollonius accompanies his account of Thera, or Santorin, with an interesting legend. 'Euphemus, in conformity with the advice of an oracle, threw a morsel of earth into the sca, then there grew up an island, which was called most beautiful ( $\kappa a \lambda \lambda(\sigma \tau \eta)$, and which has been the sacred nurse of the children of Euphemos.'

This was supposed to have occurred about the time of the expedition of the Argonauts to Colchis. It is a curious fact that the neighbouring Anaphi was supposed to have been raised by Apollo out of the waves for the benefit of these wandering heroes. And the fact of the appearance of islands in the Egean Sea is associated with the earliest myths, such as the preparation of Delos for the birth of Apollo.

When, therefore, did Santorin go under the name of the most beautiful? Was it before the eruptions buried it with the present layer of pumice, or was it after this, when it was level, and exceedingly fertile for the grape? However hideous it may seem to us, we know that our idea of the beautiful and that of the ancient Greeks differ considerably.

And then it was called Thera. 'Was it because it was a monstrosity?' ( $\theta \eta \rho, \theta \eta \rho \grave{s}$, a monster), I asked Dr. Dekigalla, or De Cigalla, of Santorin ; to which he indignantly replied that it was nothing of the sort, and that it was called Thera after a son of a Spartan hero of the race of Kadmos, and Santorin after St. Irene. Verily Santorin has changed its name as often as its form, and now the Greeks, who revive everything that is old, call it Thera in preference to the name Santorin, by which it was known during the middle ages.

Naturally the eruption of 198 B.C. was looked upon with the greatest awe, and the Rhodians, who had then the supremacy in the Ægean Sea, hastened to build upon the newborn islet a temple to Poscidon Asphalios, and for 
the sake of euphony it was called 'sacred island.' For this event we have luckily ample authority, Strabo, Seneca, Eusebius, Pliny, and others, who differ slightly as to date, but in substance their account is similar. Strabo says, 'Between Thera and Therasia flames issued out of the sea for four days, so that the whole sea seemed to seethe and blaze. These flames created little by little, as if with tools, an island composed of volcanic bombs.'

Plutarch goes further, and tells us that it was in fulfilment of a Pythian oracle. In short, we can gather that the whole world at that time was aghast at this sudden apparition, but we must remark that another convulsion which separated Thera from Therasia is not alluded to. Pliny in his account of the eruption of 198 mentioned it as a recognised fact that this northern channel into the basin was made by a convulsion. And this fact on examining the spot is obvious, for in the sea near Therasia are engulfed the remains of buildings, and on a hidden reef lying close to the Cape of Epanomerià a few years ago sponge-fishers from Kalymnos found and took away with them a marble lintel, of good workmanship, with the pattern of a rose upon it, from which it is likely that this separation took place in historic times.

The next eruption about which we have any information seems to have increased Old Burnt Island by a cape, now called St. Nicholas, about the year 60 A.D., according to George of Syngelos. And in the old chronology of Theophanes there is reference to another, in 726 A.D., in the reign of Leo the Isaurian, when they saw the sea boil like a furnace, and thick vapours came out of it, and pumice stone covered the sea far and wide, and a rock appeared which united itself with the Old Burnt Islanc. 
About an eruption in 1457, when a portion of the Old Burnt Island detached itself and was engulfed in the sea with a great noise, the only authority we have is a Latin inscription in the Church of the Jesuits, in honour of the then Duke Francis Crispi II., in the old fortress capital of Santorin called Scaros.

About the appearance of Little Burnt Island in 1573 we have better authority, for the Jesuit Father Richard gives us an account of it as follows:- 'There are many old men in Santorin who say they saw an island formed near ours in the middle of the sea, and that it was called Little Burnt Island.'

But for the terrible eruption in 1650 , when an island called Kolombo rose out of the sea, outside the island cone to the north-east of Santorin, we have ample information ; and the appearance of this island shows us how far the cone extends underneath the sea, boring right under the island, which may be said to be only a thin crust of earth forming the lip of the crater.

Father Richard's account is written in Greek verse, and tells us all they suffered during that awful time. In 1649 such terrible earthquakes shook Santorin that the inhabitants seriously thought of abandoning their island. In March 1650 these grew worse, and huge detached blocks rolled down into the sea, killing people on their way. Clouds of thick vapour and flames were seen to issue out of the sea at the spot where the island eventually appeared, accompanied by a fearful stench, and the sea turned green; but it was not till September 28 that the volcano burst forth with a fearful noise, and Kolombo appeared whilst the people were in church praying for deliverance and mercy. So great was the noise that it was heard as far as the Dardanelles, and in Chios they thought a naval engage- 
ment was taking place. At the neighbouring island of Ios a wave fifteen yards high rose, and a Turkish fleet off Keos was driven against the coast. For a whole day and night the inhabitants of Santorin were enveloped in such thick sulphurous smoke that they could not see the sun. Gold, silver, picture frames all turned black. Many were blinded and all suffered from their eyes; fifty people died of these noxious vapours and a thousand animals were asphyxiated. A boat was returning from Amorgos, and chanced to pass through this gas; it was found floating a few days afterwards with all hands on board dead. Even when the worst was over, and the inhabitants ran down to the shore to see what had happened, many of the most venturesome were asphyxiated. But what puzzled the people most was that some of these asphyxiated people revived just as their friends were mourning for them and preparing for the funeral, so that the priest had to return home with his stole and his cross unused. This terrible time, even after subsequent eruptions, was known as the year of evil. The island of Kolombo gradually settled down below the sea-level, and this cone is now a reef ten to twentyfive fathoms below the sea-level, and having an elevation of a hundred fathoms below the actual bottom of the sea.

The next eruption was in 1707 , when New Burnt Island appeared in the centre of the basin by the side of the Old and Little. We are indebted for an account of this to an Italian MS written by Mr. Delenda, then the English consular agent at Santorin. He tells us that on May 8 (old style) there was an earthquake; on the I2th, at two in the morning, a rock like a ship in distress appeared, which they went to look at in boats, but were terrified to find it only a rock. Some of the 
bravest, after an hour's deliberation, and enticed by the oysters and shellfish thereon, ventured to land. At length the sea became mixed with sulphurous vapours, and the rock grew in size, and on June 30 around it the sea became as white as milk, and all fish in the harbour died. Smoke and flames now issued out of the sea, and much damage was done to the vines, and the inhabitants night and day heard rumbling noises and experienced successive shocks of earthquake, whilst huge volcanic bombs were shot into the air, with less and less force and frequency, until the humours of the volcano were exhausted; but it was not really at rest for six years from its first commencement. In I 708 Father Tarillon, who also wrote a reliable account of this eruption, and some other ecclesiastics ventured into the mist, and were nearly stifled by the heat; the water was boiling all round them, and when they got back they found that the heat of the water had taken all the pitch off their boat.

Nothing happened to this mysterious workshop of Vulcan until January I866, when scientific men from all nations hurried to Santorin to witness the great phenomenon. This eruption continued till 1870 , and day by day Dr. Dekigalla (whose acquaintance we made), of Santorin, an elderly man of extensive learning, and a reputed medical author in Greece, jotted down ercnts as they happened; his diary has been published, and forms a valuable history of this eruption. It does not, however, appear to have been so terrible in its effects as its predecessors : there were the fiery bombs, three newborn islands appeared, one of which was called George I., after the king; they grew in size day by day, until they attached themselves to the New Burnt Island, and thereby lost their identity. The sea was green, the water hot, sulphurous smoke covered the towns and 
villages, which were in the line of wind, and great inconvenience was caused thereby. Naturally terrible fears visited everyone, and all were eager to flee; the convent school despatched its pupils and the richer inhabitants fled. But Santorin is a rich and prosperous island; nowhere in Greece do grapes grow so well as here. So mankind, ever trusting in the lengthened pauses between each convulsion, returned to a life of contentment and security, even though it is over one of the most terrible of known craters. What may happen next no one can know. The crater opened outside the circle in I650; Therasia broke off, when we cannot say; the land in many places has subsided. Another eruption may suddenly come on, and cover Thera with feet of pumice or engulf her in the sea. And yet the inhabitants are happy, and amass money year by year; for, as say the Greeks, 'he who has money has a tongue.' After Syra, nowhere in the Cyclades are there so many well-to-do people as there are in Santorin.

The action of this volcano must have had, in the course of ages, a powerful influence over the inhabitants ; for, from their position, the towns, built on the edge of the cliff overlooking the basin, are as if placed in an amphitheatre to overlook the mysterious workings of their volcano.

The eruption of 1650 is the first about which we have information as to the effect on the inhabitants. One of the MS. accounts, of which we have four, tells us that most people suffered from sharp pains in the eyes, which watered profusely, became gathered and closed, so that for a day and a half most of the Santoriniotes were entirely blind. The eruption of I 707 was similar in its effects but less grave. Father Tarillon and others attest 
to the noxious effects of the gases and sulphurous emanations on the health of the inhabitants.

The effects on the nervous system which such terrible sights would have on a credulous and uneducated population, who saw giants in every pillar of smoke and spent most of their time in churches praying for deliverance, can well be realised. Processions and fastings without end were instituted, so that even the suckling babes and animals were made to fast, and the bishop carried the sacrament about barefooted. During this last eruption special attention was paid to the effect on health, and the results showed that eye affections, biliousness, bronchial maladies, and maladies akin to it were very prevalent during the time; whilst fevers, rheumatism, consumption, and various chronic maladies, which are usually rarer at Santorin than elsewhere, were notably ameliorated.

Each town suffered from the fumes according to the wind. Even the inhabitants from Ios, thirty miles from Santorin, and Anaphi, twelve miles east, and Sikinos thirty-five miles north-west, were subject in a less degree to the influence of these gases when the wind brought them in their direction. The effect on plant life was even more marked: the slopes of Mesa Bounò looked as if they had been burnt by a long drought, the asphodels, so common elsewhere in the Cyclades, were all dried up and killed; but the volcanic emanations were favourable rather than the reverse to the vines, which for some years previously had been suffering from a blight, which this wholesale application of sulphur entirely removed.

Everybody we told that we were going to Santorin had some new story to tell of its horrors, and the neighbouring islanders believe firmly that the crater of Santorin is the entrance to Hades, whither, say the Naxiotes, our 
good bishop has driven all the vampires and ghosts, so that they are very numerous here, and roll stones down the cliffs at travellers. A curious fable current amongst the neighbours shows the dread Santorin is held in. It runs as follows :-

'Years ago-one hundred and fifty perhaps-the caïque of old I aimos was on its way to Rhodes; whilst at sea a storm came on, so they had to seek refuge on an unknown island. When day broke they saw three mules coming down the hill laden with three huge stones; they came down to the shore, discharged their burden, and clid the same thing several times. The sailors looked on with astonishment, for the mules came and went, and there was 110 one with them; so one of the bravest went up to a mule and struck it with his stick, whereat the mule turned round, and in a man's roice said, "Do not strike me, cousin;" and when the sailors appeared awestruck the mule continued, "It may appear extraordinary that I call you cousin, but know that I am not a mule from birth, but a man undergoing punishment. I am your cousin Papa Matsi, who deceived many with my lies, and these are two compatriots undergoing the same sentence. The spot is called Burnt Island, and it is near Santorin. Go to my country and perform spiritual offices, that our souls may have some peace."'

After these few remarks on the nature of the island we were about to visit the reader will better understand the impressions created. It is a hideous island, fascinating in its hideousness. No swallows build their nests here, no frogs are to be found on it, and the scaros, a fish by no means common in other parts of Greece, is a constant visitor to these mysterious waters. 


\section{The Island of Santorin, or Thera.}

On entering the basin of Santorin one experiences directly the pleasant impression of seeing something utterly new. To the left we were swiftly borne past a white line of houses perched along the edge of blood red rocks which form the northernmost point of the island. This is Epanomerià. Further on the red promontory of Scaros juts out into the basin, and on it are the crumbling ruins of the mediæval fortress; above this, on black rocks, is perched the white village of Meroviglia, I,000 feet above the sea, which commences a long line of white houses, nearly two miles in extent. which blends itself with Pherà, the present capital of the island.

The steamer stopped in front of a nest of houses, clinging to the eliff, which forms the little port. And what astounding houses they are! for the most part only holes chiselled in the soft volcanic rock, and faced with a fronting of stone, in which is a door, a window above it, and perhaps one on each side. Half the inhabitants of Santorin, in spite of the encouragement given by Government to the building of regular houses, prefer to live like rabbits in the ground. The capital and one or two of the principal villages now boast of handsome houses properly built, but some of the remote villages are still mere rabbit warrens excavated in the pumice-stone rocks as they have been for centuries.

The wall of rock is ascended by a newly made zigzag path, which joins Pherà and her port, $95^{\circ}$ feet beneath her-which 950 feet are composed of countless layers of volcanic eruptions in contorted lines of black and 
red. Here and there a little verdure clings to the cliff; here and there the little houses peep, like owls, from out of the rocks; and huge black boulders, which have been loosened and fallen in times of earthquake, stand ominously threatening on the next opportunity to roll down and crush the houses by the harbour.

Frequent accidents occur from the loosening and fall of these rocks, and a word peculiar to Santorin

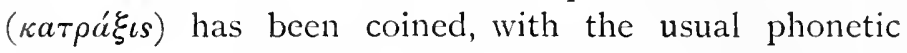
success of the Greek tongue, to express their crushing roll. Santorin contains many quaint words, too, of ancient origin; anything done on a sudden is said to be

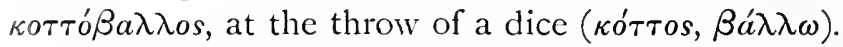

Altogether Santorin is an awe-inspiring spot, and we did not know whether to be glad or sorry when the steamer went away, and left us for a fortnight's stay in Vulcan's palace. The eparch of Santorin is a personage of some importance: he is one of the Pariote family of Mavrojenes, and has Ios, Anaphi, and Amorgos included in his eparchy. He received us with great cordiality, placing at our disposal an empty house with seven rooms, and sent across furniture of his own for our use, and placed us under the immediate care of Kera Maria, an old woman who is employed by everybody in Santorin as cook if they wish to give a feast; consequently we had not to fear the hardships experienced in other islands.

Really if Pherà, as the capital of Thera is curiously called, on the same principle that in modern Greek Thebes is called Pheba (pron. Pheva), had but a few trees to shelter it, it would be an inviting residence in the summer, perched, as it is, high above the sea-level, and commanding views of an astonishing character over the basin, the volcanic islands, and the distance. There are delightful walls on the cliff to the right and left, the 
houses of the well-to-do are large, and there is a pleasing air of prosperity in the place. All the houses of the poorer class which are not made in the ground are onestoreyed, with vaulted roofs of stone, and covered inside with excellent cement made out of Santorin pumicestone. These houses are firm, and resist earthquakes better than flat roofs; and then wood is too scarce in Thera to be used for building purposes, except by the rich. The parish church of Pherà is a curious object to look upon : it is built out of bits of red lava, which look like irregular bricks fastened together with cement. Inside there are some good old pictures and a rich tempelon, for at the times of the eruptions the pious have vowed many things to their saint in their extremity. St. Peàce, that is to say, St. Irene, the Byzantine empress, who has supplied Thera with its new name, is the protectress of the island; on her day (May 5) they have grand fêtes and rejoicings, and on her day, oddly enough, the emissary of Hypselantes in I82I unfurled the banner of war and roused the Santoriniotes to revolt.

Before starting on any other expedition in Santorin we felt it our duty to visit the centre of volcanic activity on the Burnt Islands, in the middle of the basin ; accordingly the following morning found us down at the harbour again, and crossing over in a boat to the now slumbering cone. It only took us half an hour to get across to New Burnt Island, around the summit of which, four hundred feet above the sea-level, volumes of smoke still wreathe and curl to prove that it is only slumbering to wake again.

There are plenty of ships in the bays and creeks of the Burnt Islands; for here they can get that anchorage which the steep cliffs of Santorin do not 
provide; and furthermore by a ten days' stay in these waters the bottoms of the ships become clean without any effort on the part of the sailors. Close to where we landed on New Burnt Island the water is of a bright orange colour; we had noticed this from the other side, and were curious to examine it. The water, likewise, is almost at boiling heat in parts, and where it was cooler we bathed our feet, for a hot foot-bath is a rarity in the Cyclades. The cause of this colour is oxide of iron, which comes out of the cone, and blends with the sea, colouring it for some distance; and then in the water are bubbles of vapour, which stick to the hairs of one's legs.

Before the last eruption there was a bath establishment here, consisting of a church and several houses, much frequented in summer time by invalids; all that is left of it is the vaulted roofs of two or three houses standing out of the water. Since that time, not a soul has ventured to sleep on this side. The aspect of everything is infernal beyond description; not a tree grows here, except a few figs, the fruit of which is considered of surpassing excellence. All is black, save a few bright coloured stones and streaks of sulphur; huge blocks of lava and broken volcanic bombs lie about everywhere.

The ascent, though only four hundred feet, is anything but easy, owing to the ashes, which give way beneath the feet, and the jagged promontories of red and black lava rocks which have to be passed. On the summit there are extensive lava fields, in parts too hot to be touched, and on which we were told we could have poached eggs if we had had any with us. Out of fissures in the mountain smoke was pouring pretty freely, the sulphurous fumes of which gave one some faint idea of what the inhabitants of Santorin must have suffered 
when enveloped for days in it at the time of the eruption. Large patches of bright yellow sulphur adorned this extraordinary spot. No wonder it excites awe in those who live near it! The sailors who rowed us home told us wonderful tales of their reminiscences of the eruption. The Hephrstus, as they call it, is to them a terrible unknown foe; the inward groanings to them are the furious battle-cry of an infernal deity. The story of Vulcan at his forge was the natural outcome of such wonders on the imaginative mind of the Greek of ancient days.

Pherà has many Roman Catholics in it, for in the middle ages numbers of Italian and Spanish families settled here : these families still take the lead, and possess the finest houses. There are the Dekigallas (De Cigalli) and Barozzi, of Italian origin ; there are the Da Corognas and Delendas, of Spanish origin, said to be remnants of the wandering Catalans who haunted these seas in the fourteenth century, and some of whom reigned, as we have previously seen, ${ }^{\prime}$ in Siphnos. There is a convent, too, in Pherà, where the young ladies of Santorin are taught French; so the upper class inhabitants of this town consider themselves very Western indeed, and give themselves airs which are highly displeasing to the Greeks : never was there any love lost between devotees of the Eastern and Western dogmas.

On the following morning I set off for a walk along the cliff to visit the old ruined town of Scaros, where the Italian princes who were younger sons of the dukes of Naxos held their court. All along the cliff the town continues as a thin line-sometimes only one house or windmill thick-until Meroviglia is reached, which stands considerably higher than Pherà, and is conspicuous on all 
sides by a tiny white church which crowns a pinnacle of black lava, rising a thousand feet straight out of the sea.

Below Meroviglia the red rock on which Scaros is built juts out into the bay; on the top of it is the castle of the medieval rulers, and around cluster the old houses which were abandoned only twenty years ago because they were falling into the sea; and the last inhabitant, an old woman, had to be dragged away by main force, so attached was she to the home of her ancestors. Few visit the spot now, for the approach is difficult; but wishing to find an inscription on the cliff which, the demarch of Meroviglia told me, showed that this rock was once called the Mount of Jupiter, I climbed over a good part of it without discovering the object of my search. Inscriptions have been found here, and traces of old Hellenic walls, which prove that it was the town which Herodotus alludes to as Emaios.

From one point of view the crumbling ruins of the mediæval town are interesting, for they show the strength of the vaulted cement roofs, which only fall to pieces in huge masses, the arches being firmly wedged together and levelled with cement; some of these houses are twostoreyed, and hold together in a remarkable way. Scaros must have been a strong spot in ancient days, and one can understand how a place like this managed to resist the Athenian lordship in 43I B.C. The demarch of Meroviglia has a quantity of antiquities collected from here, which he showed me on my return to his house for a cup of tea and rum-a favourite beverage here on a cold day.

On the following morning we set off for a long walk to explore the slopes of the island, which gently lead down to the outer sea. The aspect of the place is ugly enough in winter, and resembles a brown flat plain 
covered with hampers, for at Santorin they always weave the tendrils of their vines into circles, the effect in winter being that each vineyard looks as if hampers were placed all over it in rows and at intervals of every two yards. The Santoriniotes treat the vine differently to the other islanders, for here they plough their vineyards instead of digging them, and, contrary to the biblical injunction, I have often seen a bullock yoked to a mule in so doing.

For the first two or three years after planting a vine they cut off most of the shoots, leaving only a few trailing on the ground, after which they weave them into the above-mentioned baskets, which in summer are quite hidden with leaves and fruit. This hamper increases in size year by year, until after twenty years it is cut off and the vine is left with only a few branches, of which some are trailed round in circles and others left lying on the ground. This work is done yearly, and has the local name of $\kappa \lambda a ́ \delta a \nu$.

The wine of Santorin is certainly most excellent, and is drunk largely in Russia ; much, too, finds its way, wiâ France, to England under the name of claret; but a cunning wine-maker has christened a certain brand 'Bordeaux,' and hopes by this artifice it may sell in England without passing through a French cellar, which entails considerable reduction in profits. But the best wine in the island is a white one called 'of the night' ( $\tau \hat{\eta} s \nu v \kappa \tau o ̀ s)$ because the grapes of which it is made are gathered before sunrise, and are supposed to have a better aroma from this cause. They make more wine here than anywhere else in Greece; they have seventy different kinds of grapes, the best of which are chosen for making that abominably luscious production called 'vino Santo': the grapes are exposed on the roofs in 
the sun for fourteen day's before they are pressed; hence sweetness and consistency are acquired.

Without her vineyards Santorin would be a desert. There is not enough barley grown to support a quarter of the inhabitants, there is not nearly straw enough for the mules, which deficiency is supplied by giving them the soft shoots of the vines to eat, whereas the extraneous branches are given to the hens. Even the branches and old hampers which are despised by the mules and the hens are not sufficient to supply the inhabitants with wood enough for their cooking purposes. Every article of clothing and every household utensil come from without; even water in years of drought has to be fetched from the neighbouring islands; and as we toiled through the basket-covered fields, the thin light soil of which made walking such an exertion, we regretted that it was January, and not July, when all those baskets would be green and the grapes would hang temptingly around.

Everywhere we passed cisterns excavated in the ground and coated with cement. Some of these are thirty to forty yards in circumference, for Santorin is almost waterless except for that collected in these cisterns. Every house has its own cistern, and public ones are kept at the expense of the community at fitting intervals along the roadsides, and provided with a pail for drawing up the water, and troughs for the mules to drink out of.

Only three natural springs exist on the island, and are in that part which is not volcanic. One of these is called the 'life-giving stream,' and has the curious anomaly of flowing more plentifully in drought; on the same formation four wells have been dug; the rest of the island depends entirely on its cisterns. Considering that the water collected into these reservoirs flows from 
all sides, from courtyards and alleys, the property of pigs and dogs, I felt rather chary about drinking it ; but in reality it is most delicious water, the pumice-stone cement apparently purifies it ; it is clear as crystal, and cool, but produces rather than allays thirst.

We passed the great monolith in our walk in the middle of the plain, with a convent nestling beneath it, where there is the festival of St. John of the Monolith once a year; and midday brought us to the curious village of Gonià, of which from a distance all that can be seen are the two churches, for most of the houses of the village are excavated in the pumice-stone rock.

In one of these we lunched frugally enough off hardboiled eggs and green pork sausages. They said we could get better food at the next village, but we were hungry, and, to use a Greek proverb, 'preferred our egg to-day to our fowl to-morrow.' The house was composed of two rooms, both in the rock ; the outer one the family occupied by day, with a door opening into the street, a window over it and one on each side; the inner room the family occupied by night, and into this a ray of sunlight never penetrates.

These excavated houses $(\sigma \kappa a \pi \tau \dot{a} \sigma \pi i \tau \iota a)$ are the subject of special legislation in Santorin. Those dwelling in them have no actual right to the land over their heads, but then nobody can make a vineyard or a reservoir without the consent of the householder below.

The next village we passed through is called Bothro or 'Trench,' and is a yet more perfect specimen of these Santorin rabbit warrens : the village occupies the bed of

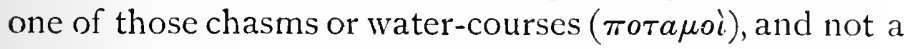
sign of habitation, except the church, can be seen until you are in the midst of it. The construction is thus. The bed of the torrent forms the street; on either side are 
lovely gardens, for in this sheltered spot everything flourishes; luxuriant prickly pears and geraniums flower all the year round, and vines hang in festoosn from trellises; the houses on either side of the street are in the rock. Each house has been chiselled out, and presents only a front wall with doors and windows. People say they are healthy; in fact, epidemics are exceedingly rare in Santorin. They are cool in summer and warm in winter, but they are damp ; and, curiously enough, though water is so scarce, the inhabitants of Santorin suffer more from damp than anything else, for the moisture created by the sea air is not absorbed by the dry earth and gets into other things. Bread becomes mouldy directly, and so do boots, salt is always damp, tools rust

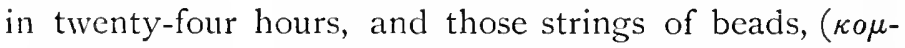

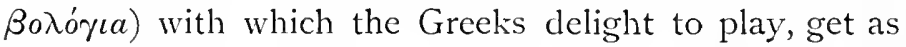
wet as if they had been dipped in water. Books decay as if from worms, and in an empty house you see spiders' webs hanging and sparkling with moisture in the sunshine. I never was more surprised than when I found mosquitos abundant in January here-they have them all the year round - and not a duckpond on the island. At Bothrò we went to visit a shoemaker renowned for his songs. He was hard at work in his excavated house, which consisted of only one large room: he had two sabounas hung over his bed, and he was hard at work with his apprentices at his craft. The songs, as sung by our friend the shoemaker, were very pleasantly illustrative of Greek village customs ; a talented man, such as he is, is recognised as the village bard; he not only sings the songs he has learnt from his elders, but he is deputed to make songs, like a poet laureate, about the passing events of life. These he teaches to his apprentices whilst they are at work ; and so, like the tales of Homer, they 
are transmitted from generation to generation. He sang us one about a woman of Santorin, who two years before had murdered her husband. For greater effect he shut his eyes whilst singing, and now and again when he felt hoarse he took a pull at the mastic bottle which an apprentice held ready for him. But his masterpiece is a song about the eruption of $1866-70$; it is very long and lasted nearly three quarters of an hour, always in the same monotonous, jerky key; but all listened intently, and so did I, for he articulated his words with surprising distinctness; and if the poetry was indifferent the facts were there, for he began :-

In one thousand eight hundred and sixty-six,

On the seventeenth of January,

On Tuesday, at four o'clock,

Hephæstus commenced his eruption;

and then proceeded to describe each event mirutelyhow professors and steamers came from afar; how Thera was the wonder of all the earth-and now and again before a pause, and as a hint that he wanted a pull at the mastic bottle, he broke his narrative with a pretty refrain :-

O Thera! loveliest isle of Greece,

Our peaceful, happy home,

Will this great dread be overpast,

Or waste wilt thou become?

At Bothrò we visited many of these dug-out houses, and found their inhabitants prosperous and sharp-witted. From what I saw I quite think the Santoriniotes are the sharpest Greeks I have ever met; they indulge in neat expressions, too; for example, if you try to do something they deem impossible, after the manner of 
English travellers they will say, 'A blind man found a needle in the straw, and a deaf man told him that he heard it fall.' And when I passed a compliment on the remark the answer was, 'Bah! bah! one less, one more, we are all mad.'

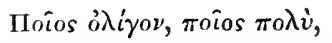

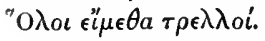

Each householder at Bothrò has his vineyard, his figtree, and his mule. There are five chalk-kilns close by, which drive a roaring trade; and the peasants are frugal, being able to work for hours without food, and drinking only water out of their gourds. They told me at Bothrò a great deal about the village festivities after the vintage, the great event of the year in Santorin. Our friend the shoemaker is always an exalted personage on these occasions ; he is sent for, even to the winepress, as they tread the grapes; there he plays his sabouna and sings his songs to encourage them in their work. What a feast they have when all this is over in each of their rock dwellings! After the feast, fires are lighted in the bed of the torrent or street, round which they dance, saying they are burning the beard of Chronos; then they part, saying, 'Tov xpóvov' (till next year) to one another.

They do deserve a little fun after the hard work of the vintage in the summer heats: there is first of all the arduous task of picking the bunches, then they have to carry the heavily laden baskets to a vault in the pumice rock (кávoßa, from Ital. canova), which serves as winepress and cellar. Basketful after basketful is poured into this press until it is higher than the height of a man. Here they leave them for eight days to compress one another with their own weight, and then comes

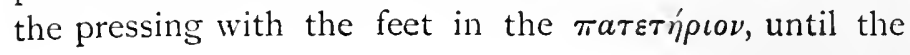


juice runs out into the $\lambda$ nvós; after which it is transferred to barrels made of wood expressly fetched from the forests of Thasos.

The church of Bothrò stands in a conspicuous elcvation above the trench; in fact, from Pherà the only trace of these four villages buried in the clefts is a row of four churches. And I felt much difficulty in believing that they were the churches of four different villages until I had paid them a visit. Under the venerable cypress by the church of Bothrò stands a plain sarcophagus of ancient date, and in another of these churches are other remnants of antiquity, for few islands can boast of more relics of the past than Thera.

Our next expedition was not so interesting; it was to the village of Pyrgos, high up on the hillside, where the coating of pumice clings to the lower spurs of Mesa Bounò and its twin peak, Mount Prophet Elias. As its name implies, Pyrgos is a fortified town or fortress much resorted to in days gone by, when pirates ventured into the basin of Santorin. It is just like all the island fortified towns, dirty and old-world, decidedly more picturesque than the long white line of Pherà, but less peculiar than Bothrò. And then we toiled up the limestone mountain to the convent of the prophet, from which vantage ground a most superb view is enjoyed. Far, far away on the southern horizon are seen Mount Ida and other snow-capped peaks of Crete ; to the east are the Sporades, Kos, Patmos, Ikaria, Samos, hugging the coast of Asia Minor; whilst around us are scattered, like leaves in autumn, the many-shaped Cyclades.

From Mount Elias the formation of Santorin is seen most easily - how the crater has spread itself and hung to the mountain on which we now were. Thera, as being the southernntost island in the archipelago, is a favourite 
halting place for birds of passage in their various seasons before commencing their long flight. August, perhaps, when the quails pass by, is the busiest of these times; and then everyone is a sportsman, for the quails perfectly cover the plain and mountains. Guns and ammunition are expensive luxuries, reserved only for the well-to-do; so those whose means are limited go forth to the chase armed with long nets which they attach to the end of a bifurcated stick; then they stand behind walls and send dogs into the fields, and they catch the quails like butterflies as they pass. During August you can buy a good fat quail for a penny in Santorin ; they keep them for months on millet seed in upper rooms, and when they are fat enough they boil them with a little vinegar and salt, and put them by.

They have cleverly contrived traps, too, for the numerous little birds which pass in October, nets which close when the birds enter to take a bait: the sportsman is concealed fifty yards off, and the little birds are attracted to the spot by decoy birds placed in cages in a fig tree. In the winter Santorin is well supplied with partridges and woodcocks, so there is no lack of game.

It was on our return from Anaphi that we landed on the southern point of Santorin known as Akroteri, a blood red promontory on which was built a white church to the honour of the sailors' patron, St. Nicholas. All around are dotted heaps of stones, left by the faithful, as in Melos, as an earnest of their return; and then we plunged into a deep volcanic gorge, and did not reach the old village of Akroteri without considerable toil. It is a huge overgrown Venetian fortress village full of labyrinthine alleys, and we were lodged for the night right at the top of the fort, where evidently in former days had dwelt the governor. 
It was the eve of St. Basil-New Year's Eve in Greece, according to the old style-so the village was en fête. The great amusement on these occasions is the 'calends,' or songs called $\kappa a \lambda a ́ \nu \delta a \iota$, 'the Greek calends,' which though twelve days late, according to our notion, really had come. Companies of children and young men club together and wander from house to house singing their 'calend song,' carrying with them an ornament somewhat like a Christmas tree, a round thing covered with green and hung with flowers and lanterns.

Their songs consist of long, chanted stories, beginning thus, 'To-day we celebrate the circumcision of our Lord and the feast of the blessed great Basil ;' then follow accounts of Christ and of Basil, and they finish up by saying, 'Many years to you!' and receive each a glass of mastic or some coppers in exchange for their good wishes. Similar festivities are carried on on March I and on May I ; also on Good Friday, Christmas, and other feasts children go round and sing, getting eggs, bread, and other gifts in return for their songs.

All round Akroteri are vast caves in the volcanic rocks, which are used as stables for cows and goats; we entered one, and terrified an old woman who was looking after her cows. She darted out past us screaming for help, saying, strange robbers had come to steal her cattle; neither was she pacified when told we were English ("A $\gamma \gamma \lambda \circ \iota)$. 'Angels!' shrieked she, 'from the infernal regions, I should think;' whereat all laughed and we thought the old woman not so discerning as Pope Gregory. The inhabitants of Akroteri were very busy visiting to-day ; each housewife had put on her best, and had adorned her table with glasses and delicious sweets. 
I should be ashamed to say how many spoonfuls of rose leaf or orange flower jam, or how many glasses of liqueur we swallowed that day, being careful to remember to wish 'many years' to all around us before touching the beverage with our lips.

Amongst other delicacies peculiar to Santorin is tyropita, which, literally translated, means cheesecake. It is a curious composition, the first ingredient being a curd of sheep's milk ( $\chi \lambda \omega \rho \grave{o})$, then some eggs, cheese, barley, cinnamon, mastic, and saffron. The impression left upon us when tasting it was that it was horrid, but the Santoriniotes are wild about it, and at Easter time, sooner than be without his cheesecake, a peasant will go through any privation. At this time they bake as many as fifty or sixty for each family, and what they cannot eat, when it is the consistency of a poultice, they dry and soak in their coffee on other feast days.

After visiting the prehistoric remains at Akroteri we mounted our mules and returned to Pherà. About half a mile on this side of the capital is the leper hospital, said to be the best in Greece. There is a white pyramid near it to warn people off, but in spite of this we went in. There are only seven inmates now, and each has a cell cut in the volcanic cliff, very tiny but clean. Poor things! they were very surprised to see us, and showed us their misfortunes - their withered hands and limbs--with an eager wish for compassion. They have their little chapel, too, with a glass partition to shut them off, and through which they may see their friends; they pressed us very hard to go into the cells and see their possessions, but we preferred to inspect them from outside. They may walk on the cliff within certain limits from time to time, but are never allowed to approach the town. All were old except one poor lad of eighteen, and I could not help 
wishing him a companion of his own age, for it must be very dull for him with four old women and two bedridden old men.

There are a great number of blear-eyed people in Santorin, dating their troubles, doubtless, from the last eruption; and a painful number of idiots and lunatics, and no asylum for them. One poor fellow I was pointed out at the café as being very dangerous at times, for when his fits are on it takes five men to hold him; they just run him into the jail till the paroxysm is past, and then let him out again.

There is something very sombre about the dress of the women here-you seldom see one out of mourning. Their heads are tightly enveloped in a black handkerchief, and when the north wind blows, and raises the thin, small dust, they cover up their faces altogether, and the north wind can blow with a vengeance at Pherà. We had a biting northern blast for three whole days, accompanied by drifting small snow-weather such as we rarely have in England for misery ; and when the only available fire is a brazier with charcoal ashes, which gives you a headache if you stoop over it, the only alleviation to your misery is to stay in bed or take exercise of an exceedingly active nature.

Deciding on the latter course on one of these days I set off for the northern town of Epanomerià. The snow and wind cut our faces terribly - at times it was almost impossible to struggle against the blast. Up at Meroviglia the ground was hard with frost; we felt perished, and decided to return to our brazier and our beds, but our friend the demarch put new life into us by another dose of hot tea and rum; so we plodded on till Epanomerià was reached. The road thither is very unevennow you climb a rock, and are perished by the wind; 
now you are in shelter, and the sun scorches: such is the winter climate on a volcano in the sunny south.

As we approached Epanomerià the volcanic rocks grew redder, and at the town itself all the formation of the rocks is red. This the inhabitants have utilised to make their houses gayer, and here there are many fine large houses, built of stones hewn out of these red rocks, set together firmly with cement, and into the cement are inserted little red stones by way of ornament.

It is a flourishing place, where most of the sea captains and pilots dwell; by one of these we were hospitably entertained on fried eggs, with pork sausages cut up with them. The captain was very talkative, asking innumerable questions about England and far-off lands.

He told us much, too, about the shipping of Santorin that interested us-how when they have built a new ressel they have a grand ceremony at the launching, or benediction, as they call it here, at which the priest officiates; and the crowd eagerly watch, as she glides into the water, the position she takes, for an omen is attached to this. It is customary to slaughter an ox, a lamb, or a dove on these occasions, according to the wealth of the proprietor and the size of the ship, and with the blood to make a cross on the deck. After this the captain jumps off the bows into the sea with all his clothes on, and the ceremony is followed by a banquet and much rejoicing. I must say that the aspect of Epanomerià is more cheerful than that of the other villages, for here all the houses are above the ground, and the Venetian fort on the headland forms a pleasing addition to the gay red houses.

On our return journey we went to visit a spot called Kolombo, on the north of the island, off which, in I650, the island which bore the same name appeared in the 
sea. There are lots of Roman tombs here cut in the rocks, which bear a remarkable resemblance to the present style of dwelling-house in Bothrò and other villages, having a low door and a window on either side; traces of ironwork are seen, and in some of the tombs there are places for three, five, or seven bodies. Close to here was once a Roman town, and into the walls of a neighbouring church is let a Roman statue.

Next morning was Sunday, and though the wind was still very cold, and occasional snowstorms passed over us, yet we could not afford to stay in bed, nor could we walk far, for we were bidden to a wedding-that of the daughter of our muleteer, who lived, not far from Phera, in one of those rock-cut dwellings.

We had heard much about weddings in Greece, strange customs having been collected by various travellers from various points of Hellas, and the union of them all had given us a confused idea of what a Greek peasant wedding in a remote island would be. I will now simply relate what $I$ saw at Santorin; it had its own peculiarities, but many of those peculiarities which we were accustomed to associate with Greek weddings were absent.

We arrived at the house about two o'clock in the afternoon ; it consisted, as usual, of two rooms excavated out of the rock. The outer one was fitted up with divans and chairs for the guests, and in the inner one, a dingy dark hole, we saw the bride being dressed by her lady friends by the light of a candle. She was a tall, handsome girl, and the first view we got of her was with her face all covered with powder, and her body concealed only by a mysterious white garment ; but when she came forth to greet us the powder had been wiped off her face, and she was dressed in a blue Japanese silk trimmed with 
drab satin and cheap lace. She had an orange blossom wreath on her head and a veil over her facc, which she raised as she kissed her guests in turn. And then she sat on a divan with her bridesmaid ( $\kappa \rho \mu$ à $\rho a)$ on one side, equally gay in trumpery European finery. Lots of female guests were assembled now in the cave-for it was no more or less than a cave-and was getting insufferably hot, and the ordeal for me was trying, for I became conscious that only women were admitted to this part of the ceremony, and I had seen more than I was intended to.

At length the firing of guns from outside announced the approach of the bridegroom, and the strains of sabouna and syravlion accompanied him. This firing of guns and playing of music are inseparable from a Greek wedding, so that it has given rise to that strange saying when it thunders, 'God is marrying His Son.'

When the bridegroom reached the doorstep the bridesmaid met him with a saucerful of honey and comfits, and a towel. He dipped his finger into the honey, and made three crosses with it on the door, one on the lintel, and one on each post. After this he ate a mouthful, which the bridesmaid put into his mouth with a spoon, wiped his fingers on the towel, and sank into a retired corner. Poor man! he looked very nervous, and, by the side of his fine, tall bride, looked a miserable specimen of humanity. Following the bridegroom came the bride's father, our muleteer, with two priests. The father had on a bright yellow coat and a red fez to-day in honour of his daughter's nuptials; we hardly recognised him as the man who had trudged by our side over so many miles of Santorin. He had just returned with the two priests and the best man ( $\kappa \circ \mu \pi \dot{a} \rho \circ)$ from his rineyard, where they had gathered the vine-tendrils, 
which were to make the crowns for the young couple; and now the pretty ceremony of making these crowns began.

Several girls were called upon to officiate at this : a table was put in the middle of the room, and a basket on it covered with a bright calico handkerchief; this basket contained the materials for making the crowns. First of all, there were two vine-tendrils twisted round and round till they formed a circle about five inches in diameter; on this foundation the crown-makers twisted cotton, with the husks and seeds still sticking to it. Over that they twined pink and blue ribbons, the ends of which were left to hang in streamers behind, and on the top of this they fastened artificial flowers with gold thread, which also hung down behind.

As they made the wreaths the maidens, two on either side of the table, sang songs; the eldest began and sang one verse, then another answered, and so on. And in these songs they wished the young couple every good wish, as follows: "May holy Procopius be with you to-day. May holy Tryphon grant you a life of pleasure and peace together. May holy Polycarp grant you many teeth in your house.' Then another of the maidens sang as she works--

Adorn the crowns with pearls and flowers;

The bride and bridegroom are the moon and stars.

She is answered by another on the opposite side of the table :-

The bride is Venice, and her swain

Is like that city on the main.

A third then sang a couplet :-

The bestman, and the bridesmaid, too,

Smell as Chiote gardens do. 
The allusion to Venice is interesting, as proving how the custom has been handed down from generation to generation, surviving the jealousy of the Italians, and Turkish changes.

When the crowns were finished, and the singing over, they placed these symbols of matrimony again in the basket, and handed them to the priests, who headed the procession to the neighbouring church. It was piercingly cold when we came out of the warm cave, and snow was falling, but my neighbour pointed to it and said, 'This is lucky' with an emphasis which at first I thought to be intended for a sarcasm, but on reflection the Greek saying occurred to me, " Happy is the bride that it rains upon,' and if the greater rarity of snow occurs it surely must indicate some great good luck. We in England have chosen the sun as indicating prosperity to the bride; in Greece they have chosen rain, the result of difference of climate, no doubt.

We went to church two and two, the priests leading the way, then the bride with the bestman, followed by the bridegroom and the bridesmaid ; musicians playing vigorously brought up the rear. The rest of the ceremony is, of course, religious, and to those who have not seen a Greek wedding it is odd enough. The altar was placed in the middle of the church, the basket with the crowns upon it, and before this the wedding party solemnly stood in a row. The chief priest then bound the young couple's wrists with a belt preparatory to reading the gospel and the necessary injunctions. Then they were given candles to hold, and kissed the priest's hands as they got them. After this came the ring ceremony, both bride and bridegroom being signed three times with the sign of the cross with the rings before the priest put them on their fingers. The bestman then 
changed them from one hand to the other, as an earnest that each was bound by the vows of the other, and the bridesmaid changed them back. More gospel was then read before producing the crowns; with these the bride and bridegroom were signed three times more with the sign of the cross before they were put on their heads, and again, as with the rings, the crowns were changed from one head to the other. After this the sacramental wine was administered, three sips each to the young couple and one sip each to their attendants, and then the newly made man and wife, bridesmaid, and bestman, with the three officiating priests, joined hands and literally danced the syrtos round the altar, quickening their steps as the bystanders pelted them, priests and all, with comfits until they winced again.

The last part of the ceremony was a trying one to me, for it was intimated that I must take a part therein. Before the altar stood man and wife, behind them their attendants holding on the crowns on the top of their heads. Each guest was expected to pass before them in turn, and administer a kiss first to the bride and then to the bridegroom; my turn came at last-there was no escape for me.

After the religious ceremony was concluded we were all invited to return to the house of the bride's father, where in the most limited space possible they danced a syrtos abominably and administered refreshments-divers kinds of jam, mastic, liqueurs, and plates of honey and almond, which last delicacy had to be eaten with a knife.

In Santorin they do not keep up marriage festivities so long as those we saw at Sikinos ${ }^{1}$ or as in Mykonos, in which island ten or fifteen days of festivity are considered usual, and at a peasant wedding, which was concluded

1 Vide p. I89. 
the day we arrived, they told us that no less than twenty lambs had bcen slaughtered, not to mention other food. But most of the quaint old customs relative to marriage in Greece have been abandoned for exactly the same reason that they are abandoning the costumes-because they are too expensive to keep up. In Mykonos they still keep up the custom of the proxenia; the man does not propose in person, but, having settled the preliminaries to his satisfaction, he sends an old female relative of his to seek the hand of the girl ; this old lady must have one stocking white and the other brown or red. In a poem by Valetta entitled the 'Shepherdess of Mykonos' this custom is alluded to thus :-

Your stockings of two colours make me think

That we shall have an offer.

If the sender of the offer is not 'made to eat gruel,' as the Greeks neatly express a refusal, then on the following Friday the parish priest and the two families assemble for the discussion of the settlement, which is in itself a religious ceremony, almost as impressive as the marriage one. Greek girls are usually well endowed, for the father, if he is able, provides his daughter with a house; sons are not supposed to want anything, and rarely inherit their father's home.

Such was our wedding at Santorin; from this and others I saw in my travels through the islands I cannot say that I think modern Greek weddings deserve the colour that has been given to them by various writers. Elaborate accounts of strange ceremonies long obsolete are compiled and supposed to be in use to-day; the real thing is quaint and pretty enough in itself, and requires no romantic colouring.

Our muleteer was ready for us next morning in his 
plain clothes, just as if nothing had happened the day before; and we started on our longest expedition on the island to the south-eastern end, where on the slopes of the limestone mountain are the chief remains of Grecian antiquities. Our road led us through the large village of 'great place' ( $\mu \varepsilon \gamma a \lambda \grave{o} \chi \omega \rho \iota \grave{)})$, with evidences of Venetian splendour, and then on to a spot called Emporion, which name testifies to the trade that was once carried on here in days now long gone by ; yet still it is a well-to-do place, and we were by no means badly housed with the demarch. At the entrance to the village is a mediæval tower, planted against the mountain side, and near it a tall, waving palm-tree; vineyards are all spread around, and the spot looked very picturesque as it climbed up a cleft of the mountain, down which cleft during the recent rains terrible torrents had poured, drowning men and cattle, and ruining houses and vineyards in its rush towards the sea.

The church of Emporiòn is interesting: four pillars of an ancient temple stand in the courtyard outside, and inside the pillars of the nave have belonged to a Corinthian temple which probably came from Eleusis, the city which once stood near here, but almost all the traces of which have been washed away by encroachments of the sea. The church bells were all clanging and pealing that evening, for the morrow was the day of the Epiphany, the baptism of Christ, the day on which the priest blesses water in the church and prepares his holy oil, and all good people were to be in church by 4 A.M. It was an effort, but I was very desirous of seeing this ceremony in this quaint old church, so I arose in time, and was rewarded.

Very quaint indeed it looked as we went out of the cold darkness into the brilliantly lighted church, and saw 
the pious populace kneeling all around as the litany was being chanted prior to the blessing of the waters. There was the font, an ancient marble altar ornamented with garlands and rams' heads, placed before the picture of the baptism of Christ; it was full of water, and illuminated with candles stuck around the edge with their own grease, whilst pots and jugs full of water of every description covered the floor near this font.

After the litany was over the priest in his gold brocaded stole went around with his cross and a sprig of basil in his hand, accompanied by two acolytes, with censers, who assisted in groaning the responses. Everyone knelt, when the priest threw the basil into the font, read the appointed portion of the Scriptures, and signed the water in the font and in the jugs with the cross. No sooner was this ceremony over than there was a regular rush from all sides with mugs and bottles to secure some of this consecrated water. Everybody laughed and hustled each other, even the priest with the cross in his hand stood and watched them with a broad grin on his face ; it was a striking contrast to the solemnity which had reigned a moment before. The font was soon emptied of its contents, and an orange which had been floating in it was presented by the priest to one of his acolytes.

Before leaving the church with their bottle of water everybody went up to kiss the cross which the priest held and to be sprinkled with water from the sprig of basil, after which he dropped as his exchange gift for such favours a coin in the plate held by an acolyte. Then they dispersed to their homes, carrying their bottle of water with them and a sprig of basil, which the priest had blessed, to hang up in their homes.

It was a lovely warm day, for a change, and we set 
out on our duties of seeing the ancient ruins. of Santorin as soon as breakfast had restored us from the fatigues of the early mass. That evening found us again at Pherà, after a hard day's work, amongst ruins which I will describe in a note. ${ }^{1}$

We reached our house belated and drenched with rain; the lovely morning had been treacherous and our paths were torrents, for the paths were the beds of torrent. Hitherto we had had a contempt for the dry torrent-beds, but they had at last asserted their use. Before the rush of the water the stalks of the water willows ${ }^{2}$ ( $\lambda$ vrapia) bent and swayed. Out of these willows the Santoriniotes make capital baskets, and drive a good trade by selling them to their neighbours. Why they are more energetic than the other islanders I cannot say. Barren and dry as Santorin looks by the side of its neighbour Naxos, its inhabitants arc energetic and prosperous; whereas in Naxos, where nature has done all for them she can, idleness and poverty prevail.

One more journey remained for us, namely, an expedition to the lost limb of Santorin, the island of Therasia - an expedition which will be to me an evermemorable one. It was only a short sail across the harbour, an hour's run with a good breeze, but our breeze to-day was rather too good, and we were drenched to the skin before we set foot on this inhospitable shore. Everything here is the same as at Thera, only on a smaller scale; a few boathouses form the port, a wretched zigzag path leads up to the row of white houses eight hundred feet above, each with a vaulted roof, which form the Chora. It was St. John the Baptist's Day,

1 Vide note.

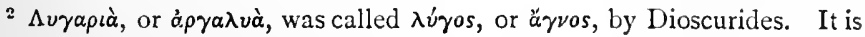
agnus castus, osier. 
an universal holiday, for St. John the Baptist follows next after the Epiphany in the Byzantine calendar. And, despite our drenched condition and the biting north wind, we enjoyed participating in the blessing of the sea which happened to be taking place. Down the zigzag path the procession wended its way, headed by priests carrying crosses, and two acolytes carrying lanterns; after them came all the inhabitants of the town, a hardy seafaring race. On the seashore a litany was sung, during which all the people knelt around, and with his cross the priest blessed the waves and then threw it into the sea. There was a general scramble now to get the cross, for the man or boy who secures it gets as a reward for facing the cold and the wet some coppers from the bystanders, which later in the day will buy him enough wine to make him very drunk and drive out the chill.

With the crowd returning from their devotions we climbed the hill and went straight to the demarch's house, where breakfast was shortly afterwards spread for us according to the abilities of our host ; hard-boiled eggs, fish, and curious cakes ( $\xi \varepsilon$ potıà) made out of flour and oil, twisted into shapes to represent flowers, baked, and then covered with honey; this meal was quite as good as we could expect on Therasia, for the demarch himself was little better than a labourer. The landlords of Therasia are, for the most part, absentees ; that is to say, they live over at Epanomerià or Pherà, and only their inferiors remain on the spot. Whilst we sat at our meal men came round with dishes begging for a subscription for a new church. I asked them what they could want with a new church on an island which had more churches in it than houses. They smiled and said it was a vow made to St. Nicholas in time of storm; and I 
thought how useful a church had been to us at Anaphi in time of need, so I gave them a trifle.

After breakfast we set off across the island to visit the mines, where the best pumice stone is found and exported, and where the prehistoric remains were unearthed two years ago. On our way we passed through Agalià ; quite the quaintest village I ever saw, surpassing even those of Bothrò and Gonià, for here the gulley in the volcanic rock is extremely narrow and deep, so there is no room for gardens ; in fact, it is a natura! street in which every house, without one exception, is hewn out of the rock; here even the church is cut in the rock, having only on one side a wall, and in a corner has been constructed a small bell tower, which is positively the only means by which you can identify the existence of sacred precincts ; until you have entered the gulley and walked up it a little way there is not a vestige of anything to lead one to suspect the presence of habitations.

Therasia is more pastoral than Thera. On the southern slopes a good deal of grain is grown, and women with their faces enveloped in white handkerchiefs were tending their goats, walking about with huge sacks on their backs in search of fodder for their mules. I remarked that here nearly every woman wore white, whereas in Thera black was the fashion. Beyond this point there was nothing whatsoever to lead us to believe that we were on a different island.

On our return to the Chora there was not much to detain us at Therasia-only the unpleasant fact that our three sailors, having been too hospitably treated by their hosts, were drunk, two of them hopelessly so, and loath to leave. In our search for the delinquents we entered into several houses, and saw the good people 
all giving themselves up to the delights of the table. One we entered consisted of only one room with no window, no light except from the door. There was a round table in the middle of the room, at which a dozen men were singing and roaring at the top of their voices round the remains of their feast; and as we appeared at the door the host would not hear 'Nay,' we must drink to our welcome and our happy return home.

All the women stood meekly in a corner contemplating us and their uproarious lords. These feast days in modern Greece are regular symposia: there was the board surrounded by men ; there were the women serving and shrinking from observation; and there was the bard, who had done his duty earlier in the feast by singing and playing the syravlion until he had impressed music and hilarity into his listeners. These are lineal descendants of the feasts of Dionysia, at which all got drunk, and were held blameless; nay, even now it is thought a crime to remain sober at these feasts, an insult to your host. As a rule, they are not a drunken race, but they have a good many exceptional days, and St. John the Baptist's Day is one which proves this rule. Meanwhile we were very unhappy about our sailors, for return to Thera we must that evening to catch the steamer on the morrow; and the wind was blowing a perfect hurricane. We could see little waterspouts, or syphons, as they call them here, all over the basin of Santorin; they are gathered wreaths of spray, which the sailors look upon with great awe, and say, 'The Lamia of the sca is travelling.' We, however, were determined to get across, and thought we had as much right to travel as this mysterious personage. I could not help admiring these little whirlwinds as they scudded along the sea, resembling wrcaths of smoke issuing from a chimney. 
To drive them away the island sailors will shoot at them. A plan they have in Santorin, which is deemed most effectual, is to thrust the point of a knife into the mast.

Outside the harbour it was blowing a fearful hurricane, a regular $\dot{\iota} \nu \mu \rho \sigma \tau \rho^{\prime} \beta o \lambda o s$, as they call it, caused by demons rushing from place to place. So associated in these islands are all horrors connected with the wind with

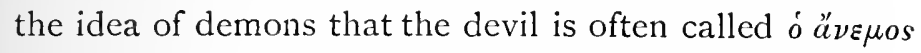
(the wind), and old women mutter 'honey and milk' to exorcise these demons in the air, as in ancient times they offered honey and milk to the nymphs who were supposed to raise these storms. In other places they attribute storms to a marriage among the Nereids ( $\dot{\eta} \pi \sigma^{\prime} \mu \pi \eta \tau \hat{\omega} \nu$ Nepai $\delta \omega \nu$ ), and the attendant festivities.

As for ourselves we felt that we were in danger, not so much from the demons of the air as from the demons of the earth ; for two of our sailors, a father and son, fought like demons in their drunken madness, biting each other on the cheeks and hands until the blood gushed out on the shore. The third sailor was not so drunk, only furiously angry with his associates; he cursed them again and again with that effectual Greek curse, the $\phi \dot{a} \sigma \kappa \varepsilon \lambda o \nu$, done by shaking five fingers at the object of your imprecation and hissing và through your teeth: it is the most deadly insult you can offer to a person, and if you dare not do it to his face, do it behind his back, and it will be equally effectual.

With great difficulty we got into our boat and began our homeward journey, and as we rounded the point which shelters the little bay of Therasia the demons of the air snatched our sail out of the hands of our soberest sailor and unshipped our rudder, causing us infinite trouble and danger of being driven on the rocks. The pugnacious father and son had to be held at opposite 
ends of the boat by our servant and myself until kindly nature closed their eyes in sleep, and thus we crossed over to Thera. It will be long before the adventures of this voyage will be effaced from our memories, and we shall in future avoid a voyage in a caique on the occasion of a symposium in honour of St. John the Baptist.

\section{NOTE 1. \\ On the Antiquities of Santorin.}

There are many interesting private collections of antiquities to be seen at Santorin. The demarch of Meroviglia had a quantity of stele and inscriptions which he had picked up near his town; and Kyrios Nomikos, one of the members for the eparchy of Santorin, who married a daughter of old Delenda, a great antiquarian, has got a splendid collection. One of these interested me especially, being a vase of white marble, round the lip of which is an Ionic inscription, proving that it was an offering to Hecate (Cf. Hesiod, 'Theo.' 4 10-450), just like the vessels they present to churches now, or the plates of choice Rhodian pottery which they insert for ornaments in the wall.

But the ruins around Emporiòn and on Mesa Bounò are the chief objects of interest in Santorin. From Emporiòn a long spur of non-volcanic rock runs out into the sea, called the promontory of Exomytis, close under which was the city of Eleusis, which Ptolemaius names in his list of the towns of Santorin, but the greater part of which has now sunk into the sea. Along, and under this spur, are many interesting tombs, and over one of these is the celebrated echendra, or serpent of Santorin, with an Egyptian beard; it is five feet long, and is carved so as to look as if it were crawling along the rock. The inhabitants look upon it with terror, and doubtless the proverb, ' The serpent will eat up Santorin,' comes from this; but whether it alludes to the volcano or the encroachments of the sea it is hard to say. Just beyond this there is a rock with a flat space on the top, and something that resembles a seat in the centre, not unlike the so-called seat of Homer on Chios; this possibly may have been a place for funeral orations, as there are graves all around-huge, massive graves, some of them cut decp into the rock. The remains of a heroon interested us much, 
being four and a half yards broad by nine yards long, with the place for the sarcophagus opposite the entrance. Now at Santorin and Anaphi, from numerous inscriptions, we learn that it was the custom to make heroes of the departed, and to build heroa in their honour, especially if they belonged to the family of Ægides. All along this 'point of the nose,' as it means when translated, are these graves, pointing to a wealthy population advanced in arts; and on our way back to Emporiòn we visited a charming relic of the past, namely, a tiny marble church dedicated to the 'Marble St. Nicholas.' This is no more or less than an ancient heroon turned into a place of Christian worship; it is built entirely of marble, and is nearly square, being four yards twenty-three inches by three yards thirty-five inches. The door on the south side has an eagle gable ( $\dot{a} \epsilon \dot{\omega} \dot{s})$ over it, and the roof is made of blocks of marble placed on the bias.

By eleven o'clock we were ready to leave Emporiòn, and went in the direction of Perissa, a spot which presumably derives its name from being the point at which people started to cross over to Anaphi. Just across on the opposite shore of Anaphi was found an inscription, from which we gather that it was a catalogue of lands given by the owners to a temple at Perissa, and now the convent of Kalamiotissa belongs to the one at Perissa. Here Ross tells us an amusing story of how a monk wished to dig for antiquities, and when Ross refused the monk had recourse to dreaming a dream about a hidden picture ; whereat the inhabitants took upon themselves to dig, and found traces of ancient worship, erected by subscription the modern church, and looked upon the monk with veneration ever afterwards.

A hideous church and convent now occupy the spot where an iron cross was supposed to have been found during this excavation; but the sea is rapidly encroaching, and will in all probability wash this all away before the lapse of many years. Half a century ago the sea was one hundred and seventy feet distant from this church, now it is only fifty feet off, and in calm weather from a boat you can distinctly see the remains of an old wall and the ruins of the houses of Eleusis buried in the waves.

But one little gem is still left behind the modern church, being a small circular marble heroon: it is fifty-four feet round, and is raised on a square basis. The roof was once supported by a central pillar, the base of which is still left, and round the outside five of the stones are covered with inscriptions late and badly cut; 
all the stones have a plain edging round two sides, but they are obviously not in their original places. Near the church we saw another stone, which evidently came from here, covered with similar inscriptions; from these we gather that colonists from Melos, Scopelos, and other places were interested in this building, having erected it probably in honour of a departed member of their colony by contributions from various sources thereon enumerated. Perissa is rich in remains of the past let into the walls of the church and convent cells.

On leaving the convent we ascended Mesa Bounò, and visited the ruins of an extensive town, which crowned the summit of the promontory now known as Mount St. Stephen, which is joined to Mount Prophet Elias by the col of Mesa Bounò. Ross spent days here investigating the ruins, which he believed to be those of $Æ$; but since his day an inscription has been found which clearly points to the town being called Thera, not $Æ$ Ea.

The little Church of St. Stephen is literally built out of antiquities scraped together on his hill; and soon after passing this you come across the walls, and enter the precincts of the old town. On the smooth cliff are many of those curious rock inscriptions, difficult to decipher and still more difficult to tell their purport. For the most part these consist of simple proper names cut in the letters of vastly different epochs, from those of early Greece to those of the Lyzantine empire. Separated from these is the simple word 'Av'́ $\gamma \kappa \eta$ (necessity), where probably once stood an altar to Necessity, such as we see elsewhere erected to Fear, Force, Shame, \&c. At Corinth, too, was a temple to Necessity, which none might enter.

The city walls of Thera are a curious mixture of polygonal and rectangular stones, which look as if both these styles of architecture had been in vogue at the same period. A little church facing west, and now dedicated to Christ, has been a pagan sanctuary; over it is an inscription now illegible, but from its position we may argue that the temple was dedicated to some infernal god. Further, on facing the south, is an exceedingly curious building, used now as a mandra for cattle: it has evidently been a temple, from its foundations, and out of a hole in the living rock behind issues a current of hot air; the peasants call it the $\mu a \nu \tau \in i o \nu$, or place of oracle, and I think they are right. On one of the jambs of the

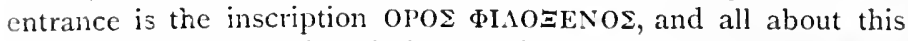
spot are quantities of inscriptions, votive tablets, and psephismata. 
On the eastern side, on the top of the hill, are the remains of the public buildings, now only a waste of pillars, bases, and architraves. Everything of value has been taken off by 'foreign thicves'-Orloff, Farvel, Ross, and others all boast of cailque-loads of treasures shipped from this mountain to Europe; and if only the Greek Government would encourage excavation caïque-loads might still be found, which could be secured for the Athenian or local museums.

All down the southern slopes of Mesa Bounò are graves, where Ross found interesting stores of these amphore peculiar to Thera, with ornaments, proving the intercourse between this island and Egypt; a subject which might be pursued with advantage, for Thera would be one of the most likely islands for communication with Egypt, possessing so capacious a harbour, valuable productions of the volcanic soil, and, moreover, being the first island of the Egean Sea at which ships would touch.

Descending Mesa Bounò on the north side we passed numerous abandoned cells, which hermits had once occupied, and then came down on Kamaris, at which spot the chief ruins seem to belong to the Roman epoch. Here, too, the sea is encroaching terribly. I)r. Dekigalla told me that forty years ago he had entered one of the caves or chambers (camere) by the sea, from which Kamaris gets its name, with dry feet, and had copied an inscription in it ; now this cave is some feet below the level of the sea. At Kamaris we saw the remains of a Roman temple, some statues of inferior workmanship, and the foundations of houses.

\section{NOTE II.}

\section{On the Prehistoric Remains at Therasia.}

The mines of Therasian earth, which lay to the south of Therasia, have been worked now for several years, and when the workmen reached a depth of thirty feet from the summit, and fifty feet inwards, they came upon the foundation of buildings. First, they discovered the walis of two buildings resting on a foundation or stratum of scoriæ, on which the pumice stone $(\ddot{a} \sigma \pi \eta \eta$, as they call the Therasian earth here) had been deposited. This left no doubt that the building in question had existed prior to the eruption which had covered Thera with pumice. On further clearing they discovered that these were the walls of rooms, the floors of which consisted of the scorize rock. The largest of the two dwellings was 
about twenty-four feet from the smaller one, and consisted of a space divided into five unequal chambers, four of which lay in a row to the north, whilst the fifth and largest faced south. It was twenty-four feet from east to west, and twenty and a quarter feet from north to south, including the hall to the east and south. The form is a parallelogram with the angles slightly curved, and the walls have apparently shelved in towards the roof. The walls consisted of volcanic stones stuck together with clay, and wooden rafters had been let in to form a flat roof, which may have been covered with mud, as those in most of the islands, for in the refuse has only been found bits of charred wood and rubble, the charred wood being so decayed that at the slightest touch it crumbled into dust. 'The 'finds' in the houses were very interesting-two tools of obsidian, one having the shape of a lance the other of a saw or toothed knife, and a ring of the same material, with traces of string lraving been attached to it; perhaps used in the loom, like the rings (3apúdıa) they attach the strings to to-day; two basins of tufa stone-one round, the other elliptical--and two stones, evidently used for grinding corn; quantities of pottery, of different forms and shapes, so badly baked that most of it crumbled away; but they resembled strongly those which I found in the graves at Antiparos,' having the same vertical holes for suspension, but owing to the dampness which had penetrated the pumice they were in a worse state of preservation. Most of these vases were full of edible material more or less reduced to cinders, but it was still easy to recognise barley, peas, anise, coriander, sesame, millet, and a sort of cheese, which must have closely resembled the modern island production of mysethra. ${ }^{2}$ The skeleton of a sheep, and in one of the rooms that of a man, were discovered very much charred. The remains at Akroteri are not so old-iron instruments were found therein, and pottery of a much more advanced age, resembling more closely that found by Dr. Schliemann at Hirsarlih than those things which came from Antiparos and Therasia, for there are rude representations on them of animal and regetable life, milk jugs with breasts, and so forth, which point to a much more recent period. Furthermore, the remains of the village of Akroteri are not so deeply buried as those at Therasia, being little more than twenty feet below the surface. It is a question of great difficulty to chronologically arrange this towngeology can speak with much greater certainty than archæology.

1 Vide note on Antiparos.

2 Vidide p. 155. 


\section{CHAPTER VII \\ IOS (NIO).}

THOUGH we had the very worst steamer of the Hellenic Company to take us to Ios, yet it was a steamer that all who travel thereon treat with respect, for it was none other than the Panhellenion, which ran the blockade in the late Cretan revolution, and carried assistance to the Greeks struggling for frcedom. A very little sentiment of this kind goes a long way on a rolling sea, and, despite the celebrity of our craft, we were thankful to leave her when she entered the capacious harbour of Ios, 'Little Malta,' as the Turks used to call it, from its affording an excellent refuge to corsairs. After the gloomy blackness of the volcanic rocks of Santorin, and the unnatural aspect of the place, Ios seemed a perfect paradise of verdure. There is nothing of any extraordinary beauty to be seen down by the quay, but the rocks are bold, the harbour fine, and the lower plain bright, where flocks abound; and the aspect is as green as in an English valley. Moreover, the inhabitants of Ios seem to partake of the genial nature of their soil, for never in all our wanderings did we meet with a family so genial and gay as the Lorenziades. One brother was demarch, another ex-demarch, and a third the schoolmaster; and the ex-demarch had three charming daughters-Marousa, Ekaterina, and Callirhoë-who 
administered tenderly to our wants, and saw to the fitting up of an empty house where we were to sleep during our stay, whilst meals were provided for us at the ex-demarch's house.

We got some refreshments down at the quay, hardboiled eggs and cold eel, whilst we awaited the arrival of the demarch, to whom we had forwarded our letter of introduction, and we thought much about Homer, and wondered if he really did die here. The town, as usual, is distant about twenty minutes from the harbour on the hillside, so the demarch brought with him muleteers to convey us thither, whose costume was very picturesque: rough home-spun coats and baggy trousers, which were dyed a sort of tawny colour, a white knitted cap on their heads, and on their feet sandals of undiressed ox hide-just a flat piece of leather fastened by thongs to the foot-most comfortable for long mountain journeys; doubtless the same that Homer describes.

In their hands they carried long sticks with iron prods at the end with which to drive their mules. The effect of this costume is very good; in fact, the prevailing colour in Ios is tawny brown for women and men alike, and it is procured by dyeing the home-spun material in the refuse left in the winepress after all the wine has been pressed out.

Ios is, as other island towns, full of pigs, though of late a sumptuary law has limited each householder to the maintenance of one; and here perhaps more than in other islands we were struck by the multiplicity of churches-pigs and churches confronted us at every turn. Ios, with scarcely 3,000 inhabitants, boasts of 360 churches, thirty of which are in the village, which is called the capital ; the rest are dotted over the island. At Siphnos they accounted for the number of churches by 
asserting the piety of their ancestors; here in Ios they told us that when anybody had sinned greatly, and wished to propitiate the Deity, he built a church, and that all these churches dated from those piratical days when Ios was 'Little Malta.'

Three gaunt, ungainly pigs ruled supreme in the alley in which our house was situated, and looked upon our arrival as an evident intrusion; and as we watched them from our balcony, and witnessed their choice of food, our àppetite for Greek bacon was not increased; just at the bottom of the alley stood two churches, the bell of which clanged perpetually in chorus with the gruntings of the pigs. Some of these churches are curiously built, consisting almost entirely of a vaulted dome over the body of the church, to which scarcely perceptible transepts were added, and a narrow porch over which is perched a thin, attenuated bell-tower. Each church has a courtyard in front of it, not unfrequently sunk in the ground, and approached by three steps, where after festival se $e_{1}$ vices the priests and people sit for gossip and the distribution of $\kappa o ́ \lambda \lambda v \beta a$.

The three daughters of our host looked well after the arrangement of our house: the bed had a valance formed of two rows of rich Greek lace, each row being six inches deep; the eikons in the sacred corner were dusted, and before them placed an incense vase, which we were invited to burn if we wished: the marriage crowns in their round gilded case looked most imposing, but the basin and jug were the most diminutive I ever saw. As soon as we were supposed to have rested Demarch Lorenziades and his nicce Marousa calleci to see if we should like to go for a walli of inspection: so accordingly we set off, and visited all the points of interest - first of all the acropolis, under which the town 
nestles, and which was the site of the old Hellenic town, as is evinced by the Cyclopean walls and cisterns; but the ruins of ancient Ios do not lead one to imagine that it was a place of great importance. There are few traces of marble remains, and the stone, being for the most part sandstone, has crumbled away and left but little to point out what the buildings once were. Also down by the harbour are traces of towers and other walls. In the various churches that we visited numcrous inscriptions have been collected; in one of them the altar rested on a pillar, turned upside down, on which was inscribed the particulars about a musical contest, and evidently once supported a choragic monument. Another church is constructed out of the remains of a temple of Apollo, the god of ancient worship here.

The demarch was proud of his town, and would not allow anything to escape our notice. We were taken to the spot where fourteen windmills run up the hillside, from which the best view was to be obtained; we were taken to the café and regaled with coffee and loukoum; we were taken to the school and introduced to the younger brother, the schoolmaster, who was deep in the intricacies of a geographical lesson, and made his pupils point out for our benefit the boundaries, seas, mountains, and provinces of Greece, which they did with unerring precision.

That evening, after a sociable dinner, at which fowls did duty in every form, a lovely surprise was prepared for us : a woman of surpassing beauty entered in the costume of Ios; a costume which is, alas! rare nowadays. The headgear was a veil bespattered with gold, with streamers which hung down bchind; in front of it was a sort of crown $(\kappa o v \rho \lambda i)$; the dress was of green and 
gold brocade. Over her heart was what we should call a stomacher, but the Greeks, in more polite parlance, an $\dot{\varepsilon} \sigma o \kappa a ́ p \delta \iota a$; her feet were in dainty little shoes

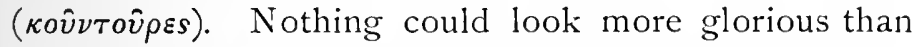
this woman, with perfect features, brilliant complexion, and rich dark hair. We stared at her in mute admiration for some time, but it was not till next morning that we identified our host's daughter Ekaterina as the original of this beautiful apparition. During dinner she had heard us talk of the lovely costumes we had seen in other islands, and she had been determined that her native place should not be behindhand. The effect of dress was never more marked than in her case ; in her everyday dress she resembled a good-looking red-faced housemaid, in her festival costume she would have graced a palace.

Ios is celebrated for its flocks and herds, and of all islands Ios is the most celebrated for its mysethra, 'food for the gods,' as they call it. It is simply a curd made of boiled sheep's milk, strained and pressed into a wicker basket called tyrobolon, just as they are spoken of in the 'Odyssey'; from this basket it gets a pretty pattern before being turned out on to a plate. When eaten with honey it is truly delicious. I have tasted the same in Corsica called broccio, but not so good as those of Ios ; in fact, the mysethra of the neighbouring islands does not approach that of Ios-there is something in the pasturage which produces the proper flavour. They make mysethra cakes, but they are inferior to the original thing, and the peasants most frequently salt them, in which condition they are perfectly horrid.

Some of this excellent mysethra we had for our breakfast next morning, and some of it, together with 
cold fish and plenty of wine, the demarch put into a basket for us to take with us on an expedition; he was determined to accompany us himself, for he said he had never been in that part of the island to which we were going, and he was a very considerable weight for a mule.

We were bound for no less a place than the reputed tomb of Homer, situated on a distant promontory to the north of the island, three hours' ride from the capital, and on our way we had ample opportunity for enjoying the beauties of Ios, and as we passed through a rich gorge full of olives, oleanders, and lemons, the ground studded with anemones, and distinguished from afar by a huge umbrella pine, we thought the lot of the Iotes was preferable to that of the inhabitants of volcanic Santorin. They recognise the merits of this spot by calling it 'the garden,' and there are one or two little villas hidden away in the vegetation which must be delicious retreats in the summer heats. It was a lovely day, and when we reached the wretched hamlet of Plaketos, close to which Homer's grave is said to be, the midday sun was almost too hot.

I always shall envy the imagination of Count Pasch van Krienen, who took upon himself the glory of having opened the tomb of the immortal poet, and of having looked upon his mortal remains as they crumbled into dust on exposure to the air. Before this imagination pales every other, even that which proposes to have opened the grave of Agamemnon, and disclosed the halls of Ilium. Count Pasch had, however, a great deal to go upon; he had read his Herodotus, and believed that Homer, on his way from Samos to Athens, died at Ios, and must necessarily have been buried. Furthermore, ships bound from Samos to Athens do still pass 
along the north coast of Ios, and if there is a southern sale they will shelter for days in the little harbour below Plaketos. There are traces of a round Hellenic watchtower, in the vicinity of which are scattered many graves. Several of these Count Pasch opened, and one he decided to be the grave of Homer because he found a coin in it with something like OMHPO乏 upon it. Perhaps the next grave which is just like it- a long ordinary tomb - he considered as the resting place of Homer's mother. Who knows?

Tradition from earliest times has honoured Ios as the burial-place of Homer. Pliny calls Ios 'Homeri sepulchro veneranda,' and there exists still a modern legend, which looks as if it owed its origin to Homer's story:-'Once upon a time there lived at Plaketos an old woman and her son in a little cottage; robbers penetrated one night into it, strangled the mother and souged out the eyes of her son. When they had gone the son buried his mother, and set off to wander through the archipelago, singing songs to earn his bread as he travelled-songs which were even better than those of Riga, and which gained for him great fame. Eventually he returned to Ios to die, and was buried near his mother.'

I wonder whether Count Pasch ever heard this legend? He would have been delighted with it if he had; at any rate, he got hold of a marble slab which was before the Church of St. Catharine, and which tradition said came from the grave of Homer. On this he thought he detected letters which looked suspiciously like Homer's name, and on these grounds he started to dig, and astonished the literary world a hundred years ago by his reported discovery.

We did not stay very long at the tower or the tombs, but returned to Plaketos, where some twenty hovels 
form a little colony celebrated for its honey productions. Several of the houses are storehouses full of the productions of the soil, and large jars ( $\psi \varepsilon \hat{\varepsilon} \lambda \lambda \circ \iota)$ in which the bees have made their honey. Hardly anyone lives here in winter, except an old man, who said he was eighty, but did not look or act as if he was sixty. He boasted of having shown King Otho and Queen Amalia the tomb of Homer, and the demarch invited him to join our repast, constantly filled his gourd with wine, and made him very merry. The poor old man sang with wonderful vigour for his years, and on rising to go came down with such a crack on a stone with his skull that we thought he must be killed, but he was up again in no time, sobered somewhat, and not so gay. I never saw a more miserable hovel than his house: it was exceedingly low, so that a tall person could not stand upright; the window was merely the absence of a stone in the wall; the door four feet high; the bed simply a collection of stones on which were placed boards and dried grass, and twigs on the top of that. Implements of husbandry impeded progress at every step; the only seats were stones; people who can live to be eighty in places like this must indeed be hardy. As for our old friend, they told us he was so devoted to the spot that he could never be persuaded to join his family in their winter migration to a more comfortable house in the Chora.

Under the influence of the wine we had brought with us everybody grew gay-the muleteers, the old man, and the demarch-and on a little open space outside the hovel they began to play some of their wild island games, which interested us exceedingly, and in which they were joined by field labourers from Plaketos.

'Wine' ( $\kappa \rho a \sigma i$, as they call it) is a really savage game: one man sits in the middle of his fellow-players with a 
long rope in his hand, the other end of which is held by another player; the game is for the rest to try to smack the man who is sitting down as hard as they can with their hands, and say крабi, whilst the other man runs about and protects the sitter, giving his assailants sharp cuts with the rope if he can get at them. In this game really serious blows were given and received with great good-humour.

They next played a game called 'first and second olive,' being an intricate and acrobatical form of leapfrog: one man knelt on the ground, two others leant against him for support, and then the players followed in succession; including the old man and the demarch, there were seven. 'First olive' simply sang out his name, bounded forward, rested his hands on the shoulder of the frog, or rather beast of burden ( $\zeta \hat{\omega} o \nu$, as they call him here), turned a somersault, and lighted on his feet on the other side. The demarch was second olive, and shouted,' Second olive with its branches,' before modestly leaping after our fashion, for he was too bulky for the somersault. 'Third olive is in the air,' shouted the old man who came next, and followed the demarch's modest example. Fourth olive was an active muleteer ; his password was, 'The fourth who misses falls ;' and he did the correct somersault, as did also fifth, sixth, and seventh olive, who shouted before leaping respectively, 'To the good ass who is behind;' 'Let us put on the saddle, let us fetch wood;' 'That we may roast the lamb on Easter day.' When there are more players on a feast day they have more sayings, which each man has to say before leaping. Even when there are twenty, each man knows his place and his password.

'The priest' ( $\delta$ matâs) is another rough game of the same nature, which was next played. Four men stood 
with their arms linked together, and moved round and round; whilst they moved thus the others tried to jump on their backs. He who succeeded took the place of one of the four, he who did not had to receive a cut on his back from a rope which 'the priest,' a sort of umpire, held in his hand for administering justice.

After amusing themselves for some time with these games it was suggested that a start homewards had better be made, as the days were not too long; and on our way we passed through what is called the upper plain of Ios, which is a fertile plateau, some 300 feet above the lower plain by the sea-level, and in the centre of which is the foundation of a fine square Hellenic watch-tower, nine yards and three quarters long by nine, built with very long narrow stones-one of which I measured was three yards seven inches long and only eight and a half thick. This tower is now used as a stable, and on the top of it has been built a cottage; the old doorway is still there, and the holes visible into which the bolts once fitted. All the stones are rounded at the edge, and the place is substantially and well built; evidently for the purpose of protecting this fertile plain.

We were on most friendly terms this second evening with our hosts, whose object seemed to be to do everything to make us comfortable. At our meal a luscious kid took the place of the fowls, and during dinner our conversation turned on local customs, which interested us exceedingly. The fair young ladies of the house knew a great deal about certain ceremonies annually performed on the eve of June 23, the vigil of St. John the Baptist's nativity, and commonly known by the name of $a \kappa \lambda \eta \dot{\delta} \sigma \nu \varepsilon s$. They were rather shy at telling their secrets at first, but Marousa was not a girl to remain shy long; and, seeing the interest we expressed in the subject, she soon con- 
sented to disclose the divinations which she and her sisters used to foretell the husbands that will fall to their lot.

Marousa and her sisters were such comely damsels that I expressed surprise that they should ever have had occasion to consult the oracle about their future lot, whereat they laughed and explained that in Ios there were so few young men, but Marousa prophesied great things from a prospective visit to Athens, which had been promised her. She really was a pattern of life and spirits in this far-off island, where life not gifted with natural buoyancy must be fearfully dreary, for unless you can, as the Greeks say, 'skip with the lambs and play with the kids,' your chance of amusement is small.

Marousa began her story:-

'First of all you must take an unused jar, and you must send a girl to fill it at the well, with strict injunctions not to speak to anyone she meets. Into this jar we sisters and our friends each put something $(\dot{a} \kappa \lambda \dot{\eta} \delta o v a)$ --an apple, a ring, a pin, and so forth-each being careful to remember the article that she has put in. Then we cover up the jar with a red cloak, and leave it out in the air all night, that it may see the stars, as the saying goes.

'Often,' and here Marousa and her sisters roared with laughter, 'the young men watch where we put our jar, and steal the contents, so that we lose our trinkets and our chance of recognising our husband both at the same time, and we daren't tell for fear of being laughed at.'

'But when no one finds our jar we girls bring it in next morning, put it on a table, and sing the following song as we crowd round it :- 
'O holy John! the forerunner, the baptizer of our Lord, Guard my love from every woe, and let his name be known.

O holy John! disclose to-day, whoever he may be,

Who loves me, who will come for me, and take me to his home.

'After singing this we remove the red cloth, and a child draws out the things one by one which we have deposited in the jar, and between each drawing we sing again, promising to adorn the church of St. John with a votive offering and so forth if he tells us true. When the vase is cmptied of these things each of us girls pours a little of the water into her shoe, and goes out into the street, and the first name she hears called by a child or anyone, such as Andronico, Themistocles, and so forth, is to be the name of her future husband.

'Then we have another plan: we pour the remainder of the water into glass phials, and cast into it the white of an egg, which forthwith forms different sorts of clouds in the water. These clouds, according to the fancy of each of us, take the form of the man who is to be our husband. If he is to be an educated man he will have a book or letter near him, if he is to be a sailor he will resemble a man holding a helm or an anchor, and if a shepherd he will be playing the sabouna or syravlion, and so on.'

Here Marousa paused, and Ekaterina took up her parable:- ' But we are not only content with knowing the name of our future husband, and what his occupation is, but we want to know the date of our wedding, and to do this we take an acanthus branch, burn it in the candle, and expose it to the dew of the night; if it blossoms forth again in one night, as it sometimes, though rarely, does, the happy girl will be married before the year is out, and by the number of nights it takes to blossom we count the number of years that will elapse before our 
marriage. Sometimes here in Ios it never blossoms at all, she added coyly, 'for there are so few young men in the place.' So we wound up this interesting conversation by promising to let their distress be known in England, and recommending them to wear the lovely costume which we had seen the night before if they wished to captivate, like the maid of Athens, susceptible travellers from the north.

It is curious that this day of St. John, the summer solstice, should be treated similarly by devotees of both the Eastern and Western Churches. Everywhere they light the fires of St. John, round which Greeks, as well as Norwegians, dance and amuse themselves. In Ireland the girls make dumb cakes, that is to say, without speaking, and sleep on them when they wish to dream of their lovers: this is closely akin to an Eastern $\dot{a} \kappa \lambda \eta_{j}^{\prime} \delta o \nu a$.

On the following morning we had another expedition to make, and the demarch, who had work to do, could not accompany us, and accordingly made his niece Marousa mount her mule to do the honours of her island. We were to visit the old Frankish town Palæocastro, as it is called, and our road led along rugged mountain sides and up steep cliffs ; these Marousa preferred to ascend on foot, for she remembered a priest whose mule had slipped, and given him an awkward fall as he was returning from the annual feast.

The fortress and the ruined town are built on the summit of a white marble mountain, which commands the north-west passage between Ios and Naxos; and the houses of the town and the walls are all built of this marble-loose, unshaped stones stuck together with a strong cement of lime and sand-so that many roofless houses were still standing, and the brilliant whiteness of the place was quite dazzling in the bright sunshine. In the middle of the ruins was constructed a small white 
church, which is the special property of the Lorenziades family; and here on September 4, the Virgin's birthday, they have a family panegyris. Each member of this family-cousins, uncles, aunts-all who can manage a six hours' mule ride go and worship here on that day, on which the population of Ios go to the Church of the Holy Theodote, in the valley below, to celebrate their festival. We entered the family church with Marousa, who did her pious duty of incensing the pictures and lighting a lamp, chatting to us and crossing herself as she did so, in anything but what we should call a solemn frame of mind; finally she made us scribble our names on the wall and on the tempelon in Greek and English, which appeared to us both irreverent and vulgar; but we thought what a pleasure it would be to the family next feast day to see these scribblings of ours, so we did as we were bid.

Close to this old town is a marble quarry lately started by a modest but impecunious Greek company ; the marble is inferior to that of Paros and Pentelicus, and it seems doubtful if it will answer as a marketable commodity in a country where marble is so common.

We ate our midday meal under a wide-spreading plane tree down in the valley, and then went to visit some tombs and vaulted chambers, evincing the existence of a considerable Roman colony here in former years ; and then Marousa took us to see the Church of the Holy Theodote, the scene of the great annual gathering of the inhabitants of Ios. The building is a large Byzantine church, with a great dome over the body of the church and a smaller one over the apse. There are two narrow transepts on the north and south, and inside the northern one was a low stone bench, with seats on either sides, at which on the feast days the worshippers 
have their common meal under the very eyes of their patron saint. When hearing of these island festivals one's thoughts involuntarily travel back to remote antiquity. There are some half-dozen cauldrons piled in one corner of the church, and large wooden spoons with which to stir the contents. Every pilgrim to the festival produces something towards this meal: the wellto-do will bring a lamb or a goat ; the poor, rice, olives, and wine. Everything is then common property, and in picturesque groups outside the church they cook their food; into one cauldron is cast the lamb, into another the goat, into another the rice, and the fragrance of the meal ascends in wreaths of smoke towards the blue heavens. There is something patriarchal in a scene like this.

The men, whilst their wives are engaged in tending the pots, indulge in their rough games on the little platform before the church-those rough games which we had seen our muleteers play the day before. All is conviviality and joy. It makes no difference to their mirth at table that they are taking their food inside a sacred edifice; they laugh, sing, and chat, and then, when they have eaten their fill, they play milder games, in which the women can take a part, within the church.

'We always come round here in the afternoon,' said Marousa Lorenziades, 'when we have had our own family panegyris, and play games with the people.' They are simple-minded folks, the men of Ios, with no class distinctions. Marousa laughed and chatted with her muleteer all the way, regardless of the fact that hers was the first family of Ios and he was an unkempt yokel.

As evening comes on, after these festivals at the Church of the Holy Theodote, they dance and play in front of the church, and do not return home till well on 
in the night, wearied with their gaiety, and saying, 'Till next year' to one another as they part.

After dinner that evening the Lorenziades had invited a large party of Iotes to meet and entertain us. So after the meal was cleared away, which to-night consisted only of different kinds of fish and mysethra, the guests trooped in and were formally introduced to us. Marousa and her sisters had arranged everything for our benefit tonight. Instead of dancing, the usual amusement at these gatherings, they were to play games such as they usually play on the annual feast-day at the Church of the Holy Theodote; and before the evening was over we saw at least a dozen of them, many of them easily learnt, and in which we could take a part without conspicuously disgracing ourselves.

'You see,' said the demarch apologetically, 'we have no theatres here, no amusements, such as you are accustomed to; so in winter evenings and on festival days we play the old games which we have learnt from our fathers.' And he assured me that every game we saw that night had been played by the Iotes from generation to generation; none of them had been borrowed from abroad; for from the similarity of some of them to our own homely games I almost felt as if they had been transplanted from English soil.

The first game they played was a species of blind man's buff ( $\tau v \phi \lambda o \mu i a)$. A victim was selected, blindfolded, and given a stick to hold in his hand. Then the players joined hands and danced round him, singing as they went. At last the blind man touched one of them on the shoulder with his stick, and put one end of the stick to his ear; then the individual thus called upon whistled at the other end of the stick, and from this whistle the blind man had to divine whom he had touched. 
Then we had hunt the ring and puss in the corner, both vastly improved by the singing, which is a necessary adjunct to all these games in Greece. They all seem to know part-songs, suited to each occasion, and verses answering one another, which they sing with considerable pathos, and thereby elevate the game from a mere romp to a musical entertainment.

The demarch was expressly fetched now to take part in a game of a more imposing character called the confessional ( $\left.\dot{\xi} \xi o \mu_{0} \lambda \hat{\gamma} \gamma \eta \sigma \iota s\right)$. An Eastern carpet was laid on the floor, and a pillow was placed upon it, on which Demarch Lorenziades solemnly knelt down; then a large sheet was put over his head, and the confession began. The first confessor was his niece Marousa, who knelt before him, and the sheet was thrown over her head, too. From under the sheet we heard the demarch's stentorian voice say, 'What have you to confess, my child?' In reply she mentioned some trivial offence, and the demarch gave her as penance to kneel for five minutes in a corner. Two or three others then followed. At length an unsuspecting damsel came to confess. "What have you done wrong?' asked the demarch. 'Nothing!' was the reply; when suddenly the demarch glided backwards from off the carpet, and from under the sheet, and four men rushed forward, seized the four ends of the carpet, and mercilessly tossed the poor girl, still enveloped in the sheet, to the exceeding delight of all around.

'This is one of our favourite games at the panegyris,' said Marousa; and I could not help thinking that if games must be played at a church this was a very suitable one, having a moral attached.

After this we had a vindictive game called 'the

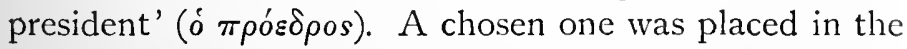
middle of the room on a chair, holding in her hand a 
knotted handkerchief. All the players were seated around, pretending to be busily engaged; one said she was busy knitting, another she was grinding coffee, and so on, and all imitating the motions. At length one jumped up, walked to the president, and, with an obsequious bow, said, 'Mr. President, Miss Ekaterina is idle; she is not grinding coffee.' If the president considered the plaint a just one the handkerchief was given to the plaintiff, with orders to administer to the culprit a verdict of stripes; if, on the contrary, she deemed it frivolous the plaintiff received stripes from the president, and returned crestfallen to his seat. The success of this game depended entirely on the genius of the players; some of them invented ridiculous complaints, which convulsed the whole company with laughter, and many of the personal hits were lost upon us, not knowing the secrets of the inner circle; yet it gave us a good insight into Greek character, which in many cases was marked by great originality and wit, excessive good humour, and quickness of repartee.

A wilder game, and one which we thought more suitable for the male sex, next took place. It was called the

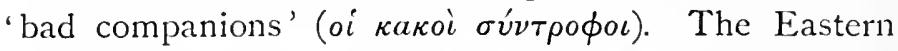
carpet was again spread, and two pillows were put upon it, and two females laid down, as if in bed, with their faces on the pillow, and the sheet cast over them, heads and all. The players, each armed with a knotted handkerchief, danced and sang around the reposers, and in turns caught them severe cuts on the back with the knotted handkerchief, saying, 'Who has hit you?' and in reply came a groan from under the sheet, 'Companion So-andso,' until the right name was guessed.

Several other games of a like nature were played bcfore we retired to rest. Whilst on the subject of games 
I will just allude here to another island game I once saw, called $\sigma \phi a \hat{\imath} \rho a$, or ball, which bears a closer relationship to cricket than anything I ever saw out of England. Instead of a bat the hand is used, and instead of wickets a stone is set up. There are five on each side; one is at the stone, four are doing nothing, the remaining five are fielding. If the player hits the ball to a certain distance he counts one, but does not run; if the ball is caught or if it hits the stone his innings are over. This game, I was assured, has been played in Greece as far back as the memory of the oldest inhabitant can go, and, no doubt, much longer; it is obvious that it was not borrowed from us. Did we take our idea from them; or will the minds of men intent on sport produce the same results in different parts of the globe?

Next morning our stay at Ios came to a close. The Lorenziades pressed us to remain for a wedding, but the wind was favourable for Sikinos, so we regretfully bade them farewell. Marousa came with a lovely piece of red Cretan embroidery as a present, and her handkerchief full of pine nuts, that we might never forget her ; Callirhoë gave us her pocket handkerchief full of sesame seeds ; and Ekaterina wrote a touching little poem with the same intent. The three brothers and the three girls went down with us to the harbour, where our boat was waiting, bringing with them a fresh mysethra, wine, and figs for our journey. They taught us to improve the wretched little wizen figs of the islands by the introduction of sesame seeds, for which plan we wcre grateful; for you might as well eat shoe leather as the figs they give you in the Cyclades. After many shakings of handkerchiefs and much tacking we eventually got out of Ios harbour, and sped quickly in our caïque for Sikinos. 


\section{CHAPTER VIII. \\ STORM-STAYED AT SIKINOS.}

WE had our misgivings when the cailque which had brought us from Ios left us alone on the shores of Sikinos, some two hours' distance from the town.

'There is no harbour in Sikinos,' said our captain when we remonstrated and wished him to stay, and when we remarked that if he did not come back for us at the appointed time we should take another caïque he only laughed at us and told us that there was only one caïque belonging to Sikinos, and this was now at Ios.

It was a fact; we found that Sikinos had only one caïque and four rotten fishing-boats which will never venture in winter time a hundred yards from the shore; it is likewise a fact that the solitary caique and the four rotten fishing-boats have to be drawn up on the beach every night, for there is no harbour. And a proverb belonging to this island aptly describes the position, 'If an army of rats tried to land on the north shore of Sikinos not one would be saved.' There is an indentation called a bay on the southern coast line into which the solitary caique can run, otherwise Sikinos is a mere rock running down sheer into the waves, about eight miles long by two wide.

When our caïque had left us we sat down on the rocks on which we had landed and ate our food, think- 
ing kindly of the Lorenziades as we did so; then we despatched our servant to the town for mules, and sat guarding our luggage in one of the most solitary places I ever was in for four hours and a half. It was a bleak, barren, weird-looking spot, with grey marble rocks towering above us, and nothing to be heard except the cry of the red-legged partridges and the occasional shriek of a sea bird. And as the wind began to rise, and gloomy clouds appeared, we looked regretfully across the narrow and now rough strait which separated us from Ios, the steamer, and the world, and wondered whether we were quite wise in visiting Sikinos at this season of the year.

It was almost dark when, to our inexpressible delight, muleteers arrived, and soon we were on our way to the Chora, across fearfully rocky, pathless hills, and long before we reached our destination it was darkness visible. The Chora, or town of Sikinos is the only inhabited place on the island, and consists of two villages about five minutes distant from each other, which divide between them the 1,200 inhabitants of the island; consequently they have not much difficulty about nomenclature-one bears its original name of the 'castro,' or camp, the other is called 'the other place': and no further distinction is necessary.

The Sikiniotes are a very primitive race of people, pure, unadulterated Greeks, who colonised the island, which was uninhabited during the middle ages. About 300 years ago refugees came hither from Crete to get out of the way of Turkish oppression, and built themselves the Castro, high up on the mountain side, where they could be safe from pirates and Turkish supervision; and here they have lived ever since, mingling hardly at all with the outer world, and never likely to be disturbed 
by the advent of steamer or telegraph. Perhaps if we had previously known how quaint and primitive the Sikiniotes were we should have arranged for a longer stay amongst them ; but the elements settled this question for us: a good steady northern gale set in almost immediately we arrived, which effectually prevented our caïque coming, as we had arranged, after two days to take us on to Pholygandros, and we were left stormstaycd amongst them for five whole days.

We plunged into the dirty Castro through a gateway, and in the dark sank ankle-deep in slush which in other countries would only have been encountered in a pigsty, and found ourselves housed by an exceedingly hospitable and jovial demarch, rough, indeed, and uncivilised ; but what could we expect better at Sikinos? His house is one of the oldest and decidedly the most respectable in the place, having about it some rather feeble traces of architectural development, for our bedroom had two hideously grotesque animals as capitals to the doorjambs, and most of the doors boasted of some ornamental decoration more or less important according to the rooms into which they led. But a damper house I never saw in all my life; all our clothes were wet and dew stood on our boots in the morning. Some boots belonging to the family which they had left under the bed were quite green with mould, but the demarch made up for any deficiencies of climate by his joviality and good fare; he seemed to live in a perpetual state of jokes, some of them not the most choice to be sure, but then he was the demarch and an old man, and had unlimited licence. He fed us well, too, and had a sucking pig expressly killed and cooked for our benefit just twelve days old. It was according to the Greek idea then at its perfection, for they say, 'A lamb or a kid should be 
three days old, a sucking pig twelve days old, and a heifer forty days old, before it is fit to eat.'

The Castro has about it all the elements of a fortified town-two entrances, one of which is a mere passage, and easily closed up in time of danger. The backs of the houses, as usual, form the wall of the town. There is the church in the middle, and in front of it the square space for dancing ; it is eight hundred feet above the sea ; and immediately on leaving the town, on the northern side, you descend an almost precipitous cliff to the shore, where up a little gully are drawn up the four rotten fishing-boats belonging to the island.

Every January 7, on St. John the Baptist's Day, the priests of the place, with all their sacred paraphernalia, and followed by all the people, go down this steep path to bless the waves and the four rotten fishing-boats. Of course this ceremony is usual all over the coast of Greece, but it strikes one as rather ludicrous here in Sikinos, where there is so very little to bless. After the customary prayer the priest throws a cross into the sea, with a stone attached to it, and an expert diver, with his clothes on, jumps in to get it out, receiving some coppers for his pains; when this ceremony is over, the priests and the people wend their steep way home again, and the sailors' minds are at peace once more, for between Christmas Day and this ceremony they are very chary about trusting themselves to the mercy of the elements.

The sailors of Sikinos, too, have another curious superstition : that if they wash their feet during the first six days of August - that is to say, 'until the candle of Christ's transfiguration is lit,' as the expression goesthey will get those round sores of which we saw so many on the bare legs of our sailors, and which doubtless come 
from poverty of blood and poor fare: these sores they call $\Delta \rho \dot{u} \mu \varepsilon s$. Now in other islands there exists a kindred superstition - if linen is washed during these days it will get holes in it, also called $\Delta \rho u ́ \mu \varepsilon s$. Theophilus Kaires, the Andriote schoolmaster, ${ }^{1}$ had a theory about thesethat during the early days of August he had often noticed a wind to blow, which brought with it microscopic animalcule, which settled on anything damp, and which produced the holes in the clothes. In a similar way I should not think it unlikely that the fast which the Church enforces at this time, coupled with the heat, would have the same effect on the blood. Schmidt goes so far as to connect the word $\Delta \rho u ́ \mu \varepsilon s$ with the Dryads of ancient days, but this appears to me a little strained.

Amongst other curious maladies known to the Sikiniotes, and which I never met elsewhere, is a disease called bird-blindness (ó $\rho \nu \theta \circ \sigma \kappa o v \nu \tau o u ́ \phi \lambda a s)$. It must be a species of ophthalmia, arising from the exposed position of the town and the great damp always prevailing here. It is quite certain, at all events, that many here suffer from their eyes, and they attribute it to the following cause-that if anyone, especially a child, drinks of water out of which a bird has previously drunk he is liable to this disease; he will become blind after sunset, and he will suffer from an unpleasant buzzing in the ears. When a child is suffering from this disease they adopt the following remedy. Several other children accompany the patient, whom the eldest and strongest carries in his arms-and as they go from house to house they sing, 'Our little So-and-so is ill; he has bird-blindness; and whosoever refuses to tell him how to be cured God will cast out.' But if the person be grown up the treatment is different : they take the heart of a black lamb and throw

1 Vide Andros, p. 283. 
it raw to a black cock, and when he has pecked at it three times they cook it and give it to the patient to eat.

We climbed one day down the cliff to see the little cleft on the northern coast below the town which they grandly call 'the northern harbour.' The four rotten boats were there drawn up the gully, with their oars and gourds ready for their owners to go out fishing on the first fine day. There seems to be no fear of robbers in this island, for boathouses and stores for fishing tackle are unknown. It is very wild and beautiful, this northern coast line of Sikinos, fertile in every kind of wild herb and flower, clinging to its precipices in spite of the kcenness of the north wind which blows upon them. The cliff was a perfect garden just now of narcissus, anemone, and euphorbia ; the little Church of St. Nicholas, which guards the four boats, is almost buried in luxuriantly growing wild mastic. Sikinos is famed for its honey far and wide, and Tournefort in his day tells us what a valuable field it was for botanical research.

The morning after our arrival was fairly fine, with the ominous gatherings of a tempest in the air; so we decided forthwith to make our one expedition in the island to the temple of Pythian Apollo, and the ruins of the old town.

Episcopi they now call the old temple, which has been converted into a church ; it is about an hour's mule ride from the town, and the road which leads to it is high up above the sea, and lined with immense fig-trees and extensive vineyards, showing the fertility of the place. The church, as may be supposed, is now covered with whitewash, and is surrounded by ruined outhouses, where once monks used to live before the disestablishment, and where the people are put up at the annual panegyris on August I 5. 
Few remains in Greece are more perfect than this temple of Apollo at Sikinos. Somehow it has escaped observation, and it has been too high above the sea to make it of any use for building material; hence it escaped during the earlier years of Vandalism ; and then when it was turned into a place of Christian worship a certain amount of respect was secured for it, which other ruins did not obtain until later years. The roof is of modern date, being a Byzantine cupola, and round the edge are battlements where the monks at the approach of pirates used to take refuge; there are still the remains of their kitchen where they used to cook when compelled to live on the roof, and of the loopholes out of which they used to shoot their assailants, in the memory of the man who now owns and tills the land around.

This personage received us with civility; he is quite a better sort of man, and considered himself superior to our muleteers; yet he is content to live in one of the deserted cells: though he has a house in the town he hardly ever occupies it. Certainly the Greeks of all classes are most frugally minded: here at Episcopi his bed is composed only of the staves of a broken barrel over which a coverlet $(\pi a \dot{\pi} \lambda \omega \mu a)$ is cast ; his plough, his firewood, some pots, and a helmet like a meat safe, which he calls his кора̀ $\xi$ (for collecting honey), a bright green jar for oil, with a bit of sponge stuck in as a stopper, lie in hopeless confusion about his cell. In the wall are two or three niches where his lantern, his water bottle, and cooking utensils are kept. His only chair is composed of two loose stones with a board on the top of them, yet he is a superior man and has ' $K u$ ú ever he is addressed.

He gave us wine, water, and a horribly nasty cake, 
composed of pastry mixed with all sorts of grasses, and called $\pi \hat{\eta} \tau \tau a$. Luckily we had provisions of our own with us, or we should have fared badly.

The demarch had a capital repast for us on our return-partridges, pilaff, and local wine of the first quality-after which the inhabitants trooped in to see us, to laugh at our host's jokes, to drink wine, and to pick up any crumbs that might fall to them from our table. Sikinos is as celebrated for its wine as for its honey, and the demarch had the best vineyards in the island. Even as far back as the days of Pliny and Strabo there was a report that the island in former days had been called Oivoi from the wine (oivos) which it produced.

Outside the wind was howling; the storm which had been threatening all day had now burst upon us; the bottle passed freely, we began to roll our cigarettes, and everyone combined in prophesying that we should not leave Sikinos, as we intencled, on the morrow. At the prospect of our detention in the island, and consequent festivities, our jocular host grew gayer and gayer, and the jokes he cracked with the women who came in would have brought a blush to the cheeks of the most barefaced Englishwoman. The result of this conversation was, that I discovered how a young Sikiniote had been born the day before, and that if we liked to witness the ceremony they would have him baptized on the day after the morrow ; 'for,' concluded the demarch, "the storm will not go down for three days and the habits of our islanders on the subject of births are well worth your study.' We were well contented at this news, and exceedingly grateful to the good woman who had so well timed her arrangements that they would provide us with an object whilst storm-stayed at Sikinos. 
The storm was raging next morning, with the fury that characterises these island hurricanes. Nowhere can more terrible northern gales be encountered than in the Ægean Sea, as they sweep over the islands and cover the sea with foam; we could scarcely stand for the violence of the gusts; but nevertheless the air was invigorating, and our quarters not too wretched despite the damp, though an earthenware pot a foot in diameter, with a handful of burning charcoal in it, is but a poor substitute for a fire on a cold day, even though bits of lemon peel are thrown in to make a pleasant odour in the room.

An old man, the former demarch, came in shortly after we were up, and begged for the privilege of taking us about the town. In many respects he seemed a man more respected and looked up to than our jocular host ; for we were told that if his age and infirmities had not interfered with the fulfilment of his duties he would still have been in office. Wrapped in a shawl, and stick in hand, he seemed to despise the cold, and trudged on at a good pace to show us his garden. Every landowner in Sikinos has a garden outside the town, surrounded by a wall, in which he grows his vegetables and figs for household consumption, and containing buildings in which are his winepress, his threshing floor, his mule stable, and his store ( $\dot{a} \pi 0$ $\theta \dot{\eta} \kappa \eta)$, where the produce of his country estate is housed, his honey, his corn, and his wine; and this is closed with a cleverly constructed wooden key. All along the hillside stretch these gardens, which have, from a distance, quite the appearance of a separate village with exceedingly mean houses.

' We are very law-abiding, quiet people (

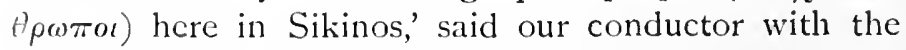
usual insular pride which leads you to infer that this is not 
the case in other islands; and it was obvious to us that thieves cannot exist here, or these gardens would soon be pillaged. Kortes was the name of the old man, and after showing us his garden he conducted us to his house, a large cold place, without any glass in the windows, just over the town gateway; there he regaled us with coffee, and showed us with pride an old altar which had come from the temple in the old town, and was dedicated to Hermes.

At the top of the hill, just above the town, the wind howled and blew most terribly; in spite of it, however, we climbed up to visit a monastic institution, lately dispersed, which was dedicated to the Life-giving Stream; on one side it overhangs a yawning precipice, down which it will soon fall if means are not taken to prevent its final ruin. But it is the same with all these deserted monasteries in Greece-another generation will hardly see one stone upon another. In Sikinos, as elsewhere, churches abound; in fact, there are more churches than houses on the island!

On our descent we were glad of our midday meal, and as soon as this was over we were taken off to pay a visit to the interesting woman whose child next day was to be received into the bosom of the orthodox Church. She was the wife of a poor man, who lived in a cottage outside the town walls, consisting of but one room, at the extreme end of which was a large bed, where the mother was perched who had presented Sikinos two days before with a male child.

In all primitive societies male children are deemed a special cause for rejoicing; here in Sikinos they are very strong in this opinion, considering a daughter a curse to a house if possible to be avoided. With this view an expectant mother is sure to provide herself with a sprig of a cer- 


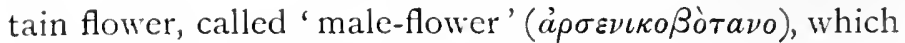
is supposed to conduce to the desired result. What slaves to superstition these unfortunate women are, to be sure, before the happy event takes place! On St. Simeon's Day no expectant mother would think of cooking or washing, or dusting, for fear the child should have ugly marks upon it. We suffered from this once in our travels, and had to be content with cold fare and male administrations for the day. When they go to the oven on Saturday - for in Sikinos bread is baked only on a Saturday-expectant mothers must use the greatest care not to tear their dress, or the child will have marks upon it called $\pi a \nu \nu \iota \sigma \tau a i$; if, by chance, this misfortune occurs the only thing then to be done is to smack their hips, for thereby they will localise the mark on the unborn child.

The happy father of a male child, immediately the sex is announced to him by Mrs. Gamp, goes outside his house and lets off his gun several times to let the neighbours know the good fortune that has befallen his family.

On our arrival at the cottage the place was full of risitors and relatives, bringing the customary gifts. A table was spread with sweets and glasses of raki, and all were wishing the mother 'a happy forty days,' for according to custom for forty days after the event she does not go to church-a custom which seems to have been directly borrowed from antiquity. ${ }^{1}$

As soon as we arrived Mrs. Gamp, an estimable neighbour, who had come in for the occasion, put a bowl on the middle of the table, into which warm water was poured, and lemon leaves, which had previously been

'In Crrecis dies habent quadragesimos insignes, namque pregnans ante diem quadragesimam non procedit in fanum.-CENSORINUs. 
boiled, were thrown, and then the relatives who stood near cast in a little salt and sugar, after which the good woman set to work to wash the infant publicly, " $\mathrm{My}$ Iron,' as his mother called him ( custom in these parts to call a child Iron, or Dragon, or some such name, to indicate prospective strength before the christening takes place.

When Master Iron's first ablutions were over Mrs. Gamp called a kinswoman, and bade her bring water to wash her hands, saying, as she did so, 'Kyrie Eleison' forty times, which is intended as a thanksgiving to the Creator that $\mathrm{He}$ has permitted her to receive a male child amongst the living.

Before the priest blesses the child, after this ceremony is over, no one is allowed to come in or to go out of the room; but as soon as the priest got to the liturgy of the Highest the door was thrown open, for then, say they, there is no fear of Nereids or Lamiæ getting possession of the newborn infant. If the family are rich the priest receives a handsome present on this occasion; but the father to-day was but a poor man, and could only give the priest a cake, which he took gladly, and went his way, after giving the babe and mother a final blessing.

Mrs. Gamp now swaddled her charge tightly from head to foot, and the guests began to depart, dropping, as they went away, a copper into the nurse's hands.

For many days to come no one is allowed to enter the house after sunset, andmother and babe are strictly forbidden to wear clothes which have been exposed to the stars unless they have been fumigated by a censer. There is something practical in this rule, for in damp Sikinos everything that is exposed to the night air becomes impregnated with moisture. 
Anent births in general, and those at Sikinos in particular, our host, the demarch, told us many curious things that evening. Generally a babe is not christened for some days after birth, unless it is a weakling, and then if no priest is at hand any person of the orthodox persuasion can baptize it by plunging it into water and saying the necessary words, to be supplemented by the priest if the child survives.

St. Eleutherios is the protector of newborn babes, and is usually called upon by the mother in her distress, as anciently was the goddess Eileithyia. Mrs. Gamp of course hurries at the first intimation that her services are required, and is sure to take with her an olive branch, which is called, from its resemblance, 'the virgin's hand '

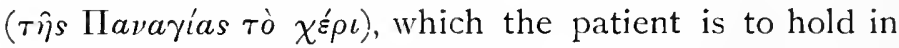
her hands to alleviate her pangs. In like manner a red straggling creeper which covers the bushes in the spring is called 'the virgin's hair' ( $\tau \hat{\eta} s$ Пavayias $\tau \dot{a} \mu a \lambda \lambda \iota \grave{a}$ ), and is considered useful to hold in cases of fever.

Greek women who work for hire in the fields are very strong, and do not allow their maternal troubles to interfere with their industry; and about these things the demarch told us much that will not bear repetition here. After birth it is considered a good thing for the handsomest man to be the first to embrace the child, so as to give it a part of his beauty, and for the strongest and wisest woman to be the first to suckle the infant for the same reason. This idea of imparting beauty and strength is an ancient one, for in 'Herodotus' vi. 6 I we have the story of an ugly child becoming the most beautiful girl in Sparta because her nurse took her to the temple of the heroine Helen, whom they met there one day; and the plot of the Ethiopians of Heliodorus turns on the belief that the 
queen of the Ethiopians had a white child because she had an image of Hesione before her when the child was born.

Generally the baptism is on the seventh or eighth day after birth ; it was in honour of us that Master Iron was to be baptized on the third day, on the afternoon of which we and many others found ourselves gathered in the metropolitan church of Sikinos to receive Master Iron.

The font was in the middle of the nave, a large goblet-shaped one made of lead; jugs of hot and cold water were brought in, and then the priest, as he conducted the service, mingled them in the font until he thought the temperature suitable for the immersion of so frail an object. In many cases, where deep fonts are scarce, and adults have to be immersed, there is considerable difficulty attending this ceremony. An Italian miner came to work at Antiparos, and got engaged to a Greek girl, who refused to marry him unless he became a baptized orthodox. No vessel could be found large enough to immerse him in in the church, so the priest and the congregation repaired to a jetty, from which the Italian was pushed off and ducked three times in the sea.

Meanwhile Mrs. Gamp was busily engaged in removing the swaddling clothes, and as the service went on Master Iron's clothing was reduced to a white cloth and a cap. As the priest mixed the water he continued reading the service vigorously, and constantly made a cross in the water by blowing upon it in that shape, as he likewise did to the baby which Mrs. Gamp held up, and to keep his long hair out of the water he fastened it behind his ears. Oil was then poured three times into the font in the form of a cross. On either side of the font stood the two sponsors with lighted candles. 
When all was ready the priest turned up his coloured silk cloak till it was nearly inside out, rolled up his sleeves, and prepared for action. Finally the godmother took Master Iron from his nurse, divested him of the white cloth and the cap, and a wee red object, like a skinned rabbit, was held up for public gaze in the hands of the priest. After oiling him in various parts the priest held him aloft, and then proceeded to plunge him over head and ears three times in the font. This ceremony over, the godmother received her charge into three white cloths with which to dry him, and after a tiny shirt and cap had bcen blessed the priest put them on; then Mrs. Gamp came to the fore again, seized the infant as her lawful property, swaddled him tightly once more, as she

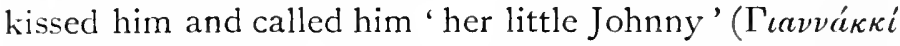
$\mu o v$ ), which simple serviceable name had now taken the place of Iron.

Johnny was not done with yet by any means, for no sooner was he swaddled than he was held upright by his legs, his cap was taken off again, and the priest cut four locks of hair, which there was considerable difficulty in finding, saying, ' One for the Father, one for the Son, one for the Holy Ghost, and one for Eternity,' as he mixed the hair with candle wax and burnt it. A blue cloak was then put on the child by the priest, likewise a hat. and a ribbon tied round his waist, which the priest dcxterously crossed round at the back, brought over the shoulders, and tucked in in front. Then the godmother took her charge and carried him three times round the font, bowing as she did so to the priest, who fumigated her with incensc. This dancing round the font at births, and round the altar at marriages, reminds one strongly of the amphidromia of antiquity. The priest then took poor little Johnny once more from his godmother to kiss 
all the holy pictures on the tempelon, and laid him on a bench alone, as if to give him time for meditation, after which he took him into the holy of holies, which was the concluding ceremony, and Master Johnny was at last properly enrolled as a member of the orthodox Church.

After leaving the church we formed a procession, headed by the priest and the baby, and accompanied by the monotonous chanting of psalms. We walked thus all round the walls of Sikinos until we came again to the mother's cottage, and delivered her up her infant, which ceremony is called the mapádosis (giving up). Great was our surprise to find her about, and bustling to do the honours of her home. She had honey cakes covered with sesame seeds and other sweets spread on a table, and lots of glasses of raki to regale us with. Again complimentary wishes were heaped upon her-a rapid recovery, a good forty days, and success to the child. Then we took our departure, promising to look in the next day to see how she and her infant were getting on.

The belief in charms for protecting newborn infants is very strong in Greece. Amulets, like those used in antiquity to avert the glance of the god Fascinus, are still hung round children's necks to charm them from the evil eye. Here in Sikinos we found the belief in the evil eye especially strong; people who are possessed of this unfortunate glance can wither up a fruit tree by simply admiring it. Old Kortes, the ex-demarch, told me that once he had an apple tree covered with lovely fruit ; some one with the evil eye went past and said, 'Oh, what lovely apples!' Two hours afterwards they returned that way, and found not a single apple on the tree, and basketfuls lying on the ground. The demarch showed me a charm which his son had worn: it was a round, 
prettily carved bit of wood, about an inch and a half in diameter ; in little circles round the outer edge were eight prophets, the bottom one representing Jonah just coming out of the whale's mouth, and in the centre was the Annunciation. Another plan for averting the evil eye is for an old woman to spit in the face of the possessor of this unfortunate attribute; for generally it only affects beauty and youth ; but to secure herself from all danger she must spit three times into her own bosom, muttering, as she does so, 'Cursed ßasкaveía' (evil eye). A good thing for everybody to wear round their necks is a threecornered amulet with salt, coal, and garlic inside, and on tying it the mother or other officiating relative should say, 'Salt and garlic be in the eyes of our enemies.' When a man is grown up he is often ashamed of such trivialities; so his anxious mother ties a bit of salt in the corner of his handkerchief, or else ties a knot in the tail of his shirt, which in some places is considered as an excellent safeguard against stomach-aches.

One other ceremony I must mention here, which is always carried on at Sikinos in connection with childhood, namely, the fate-telling, or $\mu$ ip $\sigma \mu a$ of the babe; for the old Fates are thoroughly believed in still; and for three nights after a birth friends will put valuable articles and sweets in the mother's bed to propitiate the fickle goddesses.

At Sikinos this ceremony takes place on the child's first birthday, when all the relatives are gathered together. A tray is brought out, and on it are put various objects-a pen, money, tools, an eggg, \&c.-and whichever the infant first touches with its hands is held to be the indication of the Moipa, or Fate, as to the most suitable career to be chosen for it. The meaning of the firstmentioned articles is obvious. The demarch told me 
that his son had touched a pen; consequently he had been sent to the university at Athens, and had there made considerable progress; but the meaning of the egg is not quite so clear, and the egg is the horror of all parents, for if the child touches it he will be a good-fornothing-a mere duck's egg, so to speak, in society.

Some ceremony such as this must have been the one alluded to by Apolodorus when he tells us that seven days after the birth of Meleager the Fates told the horologue of the child, and the torch was lighted on the hearth. In some places still the seventh day is chosen as the one for this important ceremony, and it is called $\dot{\varepsilon} \phi \tau \dot{a}$. When it is dark, and the lamps are lighted, a table is put in the middle of the house, a basin full of honey in the centre of the table, and all around quantities of food. Numerous oil lamps are then lighted; one is dedicated to Christ, another to the Virgin, another to the Baptist, and so forth. A confession of faith is then read, and deep silence prevails, and the saint whose lamp is the first to go out is chosen as the protector of the infant. At this moment the Fates are said to come

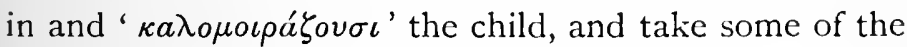
food from the table.

The demarch of Sikinos was very communicative, too, on the subject of the Fates. He told me that they are supposed to be three in number-old women who inhabit inaccessible mountains-and none but magicians

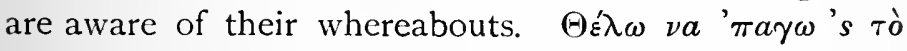

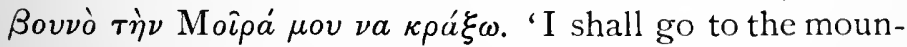
tain to call on my Fate' is a common expression of dissatisfaction with destiny.

Men who are fortunate from birth are called ' $\kappa a \lambda о \pi о-$

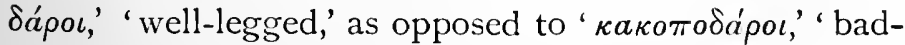
legged,' whose undertakings invariably fail. It is most 
unpleasant to establish a reputation for ill luck in the Greek islands; your best friend will close his doors against you on the first day of the year, month, or week. And, again, it is not an enviable post to be a noted person for good luck; you will be pestered with applications to be best man, godfather (compàros), and to be godfather to a Greek child means something, for the obligation of providing a trousseau for the child accompanies the title.

The Fates of to-day closely resemble their predecessors: they are always spinning the thread ( $\nu \hat{\eta} \mu a)$, as symbolical of the life of a man. They preside over three events of life-birth, marriage, and death, "the three

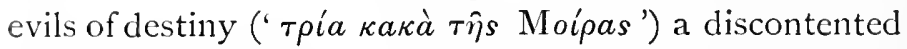
Greek will call them, who considers it a misfortune to have been born, a still greater one to be married, and the greatest of all to die.

The Fates are in some places supposed to write on the forehead of a man his destiny. Pimples on the nose and forehead are called 'the writings of the Fates' ( $\tau \hat{\omega} \nu$

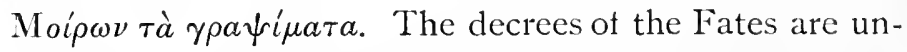
alterable. According to various legends attempts have been made to change them, but without avail. Only once a girl of Naxos, so I was told, up in a mountain village, who was excessively ugly, managed to learn from a magician where the Fates lived, and that, if she could get them to eat salt, they would go blind and change her fate. So she contrived to bring this about, and became exceedingly lovely, married a prince, but had no children ; 'showing,' concluded the legend, 'that the Fates never consent to any person being altogether happy.'

The next day was fine, and we almost thought our caique would come, but no; the Greeks are not courageous sailors, and only gave as their excuse when they 
did come, that they thought the sea would have been too rough after the storm. But it is a peculiarity of these northern gales on the islands, as soon as the wind goes down the sea is calm; whereas with a southern gale the contrary is the case: so we did not believe them.

On the afternoon of this day, which was very lovely, after paying visits to various houses and gardens we were informed that if we liked we might go and see the tail end of a wedding. Now weddings last five days in Sikinos; so I was rather annoyed that we had not been told that it was going on before, for we could easily have seen more of the ceremony, which it would have been interesting to compare with the one we saw at Santorin.

This is what they do at Sikinos on the occasion of a wedding. On the first day, Thursday, when the festivities usually begin, the crier is sent round to summon the guests to the bride's house. As a rule, in Greece the house which is to be occupied by the young couple belongs to the bride; a Greek girl without a house has but little chance of marrying, and it is a father's care to provide houses for his girls. The trousseau has been made on a simple but co-operative principle during the last week; all the lady friends of the bride have been assisting her, and now the wedding festivities have been formally announced. On Thursday afternoon they have the ceremony of the mixing of the yeast for the cakes, \&c. A reception is given for the occasion, and guns are let off to announce to all the world the coming event : this is called $\dot{\eta} \pi \rho \circ \varepsilon-$

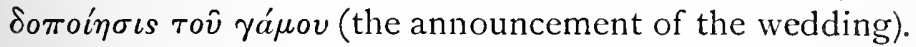

On Friday they make the sweets, to assist at which all the female friends of the bride are bidden ; and they bring with them presents of food and wood, which last commodity is exceedingly valuable in Sikinos, where few trees bigger than a fig tree grow. Guns are again 
let off, and healths are drunk. On Saturday they make the honey cake, covered with sesame seeds, and the evening is passed in dancing and other amusements.

On Sunday there is the usual ceremony of crowning, and the Church services are followed by dancing in the evening. On Monday they again have dancing, drinking, and feasting to any extent. To-day was Monday, and when we went to the house the second wedding feast, the social dinner ( $\dot{\eta} \tau \rho a ́ \pi \varepsilon \zeta a$ ), was just concluded, and they were just preparing to dance the whole afternoon. Poor bride! we pitied her very much. She was not very beautiful to begin with, and after all the dancing and excitement of her marriage festivities she looked thoroughly worn out and fit to drop with fatigue. We were given honey cakes (pastelli) and raki on an old Venetian brass dish, and then placed on the divan to watch the dancing. I have watched the syrtos so often in Greece that it usually bores me, but I have seldom seen it so well done as at this wedding at Sikinos. The men danced in their stocking feet, and they and the women were highly elastic in their movements. The bridegroom and his bestman wore fezes, no coats, red embroidered waistcoats laced behind, red sashes, and blue glazed calico baggy trousers. The semicircle of five dancers, holding to each other by handkerchiefs, waved backwards and forwards, the line closed and opened again, and the men at either end with a sort of wild Highland fling performed their acrobatic feats with consummate grace. No wonder the natives imagine the dance-loving Nereids for ever moving in this graceful syrtos. As they revolved round and round the dancers seemed scarcely to touch the ground, so light was their step.

As a finale to the wedding feast the game of packcaddle was played: the bestman, with a packsaddle tied 
on his back, and another man, with the same awkward encumbrance, perform a sort of tournament. There is a subtle meaning in their performance which amused the guests and made the bride look shy, and thus was concluded the wedding at Sikinos. At the neighbouring island of Pholygandros the agony is even more prolonged, lasting eight days sometimes; on the Tuesday they always have what is called the 'mother-in-law's feast,' another dinner followed by another dance.

On the following day our caïque came to take us to Pholygandros, and we bade farewell to our hospitable friends; as we sailed slowly away on an azure sea it looked so calm, and the islands so placid in their framework of lapis lazuli, we could hardly believe that we had'been storm-stayed at Sikinos.

\section{NOTE.}

On the Temple of Pythian Apollo and the old Town of Sikinos.

The temple of Apollo at Sikinos is eleven yards fourteen inches long by eight yards wide, and the entrance, curiously enough, is to the west. Outside the temple is a little stone bench, now used at the feasts for the seats of the priests and magnates; one of these stones is covered with an ancient inscription, which is fast disappearing, and which states that it is a votive tablet $(\psi \dot{\eta} \phi \imath \tau \mu a)$ set up by the Sikiniotes in the temple of Pythian Apollo; from the lettering we may date this inscription about the first half of the second century B.c. All around are bits of marble let into the walls, one being the remains of a statue of indifferent workmanship.

The outer walls of the temple are built of various-sized colossal stones, after the fashion of Hellenic buildings, and the corners are neatly finished off. To the east is an apse let out for the altar of the Christian church, but from the plainness of this wall and the nature of the foundations it is quite obvious that no entrance ever existed here. On the south side the wall is very deep, and the Christians evidently found it necessary to support it with buttresses, made for the most part out of fragments of the old roof; hence to 
its Christian occupation we owe the preservation of the relic. We entered between two pillars, which from base to capital are five yards high. The capitals are Doric, with two rings; the columns are unfluted, and stand on round bases. The vestibule is the modem pronaos, the roof of which is formed out of stone beams resting on the pillars and on the walls of the cella, thus forming three divisions. On these beams stone slabs rest in two cases, and in the third the roof has been opened by the monks to make room for a ladder.

The door into the cella is handsome, being about two yards wide, and over it is an inscription, now quite obliterated with whitewasl. Round the temple runs a cornice, with a frieze under it, representing a stem with branches coming out of it above and below. On the frieze rests a toothed cornice. Inside the cclla one of the stones of the floor takes up, and you descend by a ladder into a two-chambered vault, the ceiling of which is vaulted, and there are places for tombs around, now empty. The inner chamber of the vault is walled off on two sides from the outer, and is approached by a narrow passage. In the church there is a tcmpelon of considerable merit, screening off the apse, and containing on it the prized picture of the Madonna of Episcopi. Several banners and the usual Church decorations hang about, which strike one as odd in the ruins of a temple of Pythian Apollo.

Accompanied by the proprietor of the soil, we walked through the ancient necropolis of Sikinos, which lies where probably was once a sacred road from the town to the temple. Many of the sraves are still unopened, and would doubtless repay research; and if it had not been for that keen north wind I had hoped to return on the following day to open some of them, but the storm prevented me.

A bleaker and more exposed place can never have existed than that old town of Sikinos. It covered a precipitous height, fully one thousand eight hundred feet above the sea, and from the summit the rock goes down on the north side fully five hundred feet without a break. The rock is of blue marble, covered with a yellow lichen, which gives it an exceedingly rich appearance. Here and there out of crevices grow thick bunches of wild mastic; ravens rush out of their eyries and croak; quantities of partridges, too, disturbed by the unwonted noise of human voices, take flight. The foundations of houses, cisterns, and public buildings are extensive, all of the same blue marble stone of the island; one of 
these was the temple of Hermes and Dionysos, as an inscription tells us.

As a romantic spot nothing can equal the old town of Sikinos, as from the little chapel of St. Marina, on the summit, you look on one side down a precipitous cliff, on the other side over a sloping field of ruins; but the archæological value of Sikinos is centred in the temple of Apollo down in the hollow below; there is but little else to be seen of any tangible value on the island, though probably excavation might expose some treasures. 


\section{CHAPTER IX.}

PHOL YGA N DROS.

A STRING of island rocks almost joins Sikinos to Pholygandros-fantastic barren rocks, which sparkle in the sunshine, and of which we got to know every form and shape during that long day of patient tacking, accomplishing our sail of twelve miles in the same number of hours. Of all the islands of the Egean Sea Pholygandros can boast of the most majestic coastline ; in fact, I doubt if it can be equalled anywhere. A precipitous line of rocks, in places rising 1,160 feet above the sea, forms the north-eastern bulwark; as we approached it the sun had set, and the sky was lurid with that red strange light which astonished the world, and particularly the superstitious Greek world, in the winter of I 883-4. The water was almost transparent, and its depths looked wonderfully mysterious as we glided in amongst the rocks, some of which were white and looked like Nereids come to drive us from an enchanted shore. Such scenes as this make one realise how easy it has been to imagine the phantasies of the 'Odyssey' and of modern folklore.

When we saw the spot again by daylight we wondered exceedingly how we had been able to climb up on hands and knees; it is known as the Plaka, a flat rock which slopes down into the sea at an angle of fifty degrees, and which is slippery in winter with running 
water; after scaling which we had a tremendous scramble in the dark up to the town, which is built on the edge of the cliff, 750 feet above us ; and the path in winter up this side of the island is little better than a waterfall.

On reaching habitations we inquired where the demarch lived. 'Outside,' was the stoical reply. 'Outside what?' we asked. 'Not Inside,' was the angry rejoinder; and no further information could we get out of the man. We pursued our way in search of a more intelligent informant, until at length we discovered that Pholysgandros boasts of only one town, which is walled, and called 'Inside' ( $\mu \dot{\varepsilon} \sigma a)$, and of a colony outside this wall, of better-class houses, which is called 'Outside' $(\xi \xi \xi \omega)$; and a Pholygandriote knows of no other names but these.

Our new host was a very different man from our last. He was horribly modern in all his ideas; seventeen years ago he had travelled and gone as far as Paris, and since then he had lived with but one objectnamely, that of modernising his island and rooting out superstitions. He had been in office as demarch for ten years, and boasted greatly of his improvements: how he had made a good road from the town down to the southern harbour, where we should have landed if the wind had been favourable; how he had encouraged education and new ideas in agriculture : and concluded by saying, 'You will find our island a little Paris after Sikinos.'

No one can realise the power a demarch possesses in these far-off islands in the Egean Sea, especially in one like Pholygandros, where the steamer does not touch, and where sometimes in winter they are weeks without a post. He is a sort of king, or rather president of a small republic, elected every three years; and at these elections party spirit is most fearfully strained; 
for every Greek is a politician, and talks politics at his café, at his social gatherings, and everywhere, just as his forefathers did before him.

The Pholygandriotes do not care one jot about the Government at Athens; they have two joint members with Melos and Kimolos and three other islands; but they do not care a bit about their election-it is into the election of a demarch that they throw all their interest. For Athens, a king, and a parliament seem such miles away to them, it does not matter much what they do ; the demarch is elected by them, and is theirs alone, and in his rise or fall all the local interest centres.

Of course there are two parties in Pholygandros: one is an aristocratic party, headed by one Venier, of an old Venetian family, and seconded by Themistocles Mavrojenes, one of the great Pariote family, who once could boast of a hospodar of Wallachia as one of their members; and then there is the democratic party, headed by our new host the demarch, which just now is in the ascendant. At the last election they had a furious contest; blood had not been spilt or murders committed, as was the case at Siphnos on a similar occasion, but party spirit ran so high, and still continues so, that Dr. Venier and the democratic demarch are not yet on speaking terms. One day, during our stay, our hostess came, in grief, to ask our advice about her father, who was very ill and at the point of death, she feared, so that the day before they had given him the 'prayer oil' ( $\left.\varepsilon \dot{v} \chi^{\varepsilon} \lambda a \iota \circ \nu\right)$; but still he refused to have Dr. Venier called in -his hated political rival. 'He would rather die,' she said, 'unattended by a physician than have that man in his house.' It was evident that nothing could be done for the old man, whose days were numbered; so we tricd to change the subject from the hated Venier, 
as the name seemed to raise our hostess' ire exceedingly and tried to console her about her father, and to find out about their customs in Pholygandros at funerals. 'Well,' said she, 'we shall be busy when the old man passes away. No one is more respected than he, and such a lot of people would have to be invited to the "grief table" '; whereupon she was asked to explain what this meant. It appears that in this island when a death has occurred cooking is not deemed correct in the house for two or three days, so the relatives and friends bring food-' bitter

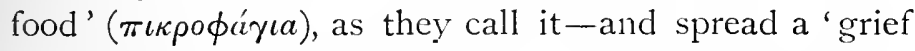
table' in the house of mourning. They hang the rooms with black, and remove the inevitable crochet from the sofas for a season. I felt an inward desire that, if the old man must die soon, he might die whilst we were there, that we might hear the lamentations and see the customs; but he did not die, and again we were told to put off our funeral enquiries till we got to Mykonos.

The prayer oil was administered to the old man, as we had been told; so I asked our hostess to explain the ceremony. 'Here in Pholygandros we generally have five priests to perform the ceremony: a table is set in the sick man's room, on which is placed a dish of wheat, and a vessel on the wheat, into which the oil is poured; five pieces of stick with cotton tied round them are stuck into the wheat ; the gospel is laid on this, and the five priests stand round with their chasubles ( on, and sing tropae, and read the suitable portions of Scripture whilst the censer is waved in the room. At the end of all this the chief priest dips a twig into the oil and makes a sign of the cross.on the sick man, who kisses at the same time the proferred Bible, and then is left to die in the odour of sanctity.'

Here again is the wheat $(\kappa \dot{o} \lambda \lambda v \beta a)$ in connection 
with death, and in this place I must relate another ceremony I saw at Aigialc, in the island of Amorgos, which bears on the same subject. It was on the All Saints' Day of the Greek Church, and every householder of Aigiale sent to the church a plate of boiled corn, generally carried by an old woman with the top-heavy troulos costume of that island. She then poured the corn into a basket placed before the high altar whilst the service was going on, and into this mass of boiled corn she stuck her lighted candle. Some of the richer inhabitants sent private plates, which were arranged in front of the tempelon and adorned with sesame seeds and elaborate patterns of almonds and raisins. After the service was over all repaired to the square in front of the church, where the chief priest sat on his throne, a stone bench with stone arms in front of the church, and the worthies of the place around him, whilst the baskets and plates of boiled corn were distributed to all who could squeeze ncar cnough to get any. Little children got handkerchicfs full of it, and rushed off to corners to devour their feast, and general hilarity prevailed 'in memory of the departed.' In other places this boiled wheat and a similar festival takes the place of a sort of harvest thanksgiving. Strange it is to see this connection between life and death represented in the old way, Demeter and her daughter symbolical always of 'sown in corruption to rise in incorruption.'

The town of Pholygandros rejoices in a most glorious situation. 'Inside,' or the old fortified town, is built on the edge of the cliff, so that it only requires three walls to protect it; the fourth side looks straight down the yawning precipice, so that there is no excuse for dirt when offal can be thrown down 750 feet into the sea without any trouble; yet 'Inside' is a very dirty place 
indeed, one street being quite impassable from the mire of pigs. 'Outside,' on the contrary, is clean and wellpaved, in every way prosperous, being the pride of its ruler, our host, the demarch. The 'insiders' represent the old aristocracy, who are slow to introduce the innovation of cleanliness.

There are lots of ovens in 'Outside'; but they only bake one day a week in Pholygandros, and a busy, amusing sight it is. These ovens are heated first of all by shoving into them an enormous quantity of burning brushwood $(\kappa \lambda a \delta i \grave{a})$.

Loaves of bread ( $\kappa o v \lambda$ iv $\rho$ a), the twisted cakes covered with sesame, $\pi \hat{\eta} \tau \tau a$ (pastics) are all arranged on long boards awaiting the moment when the oven is sufficiently heated, and the burning cmbers of the brushwood have been swept out. Everybody is busy and gay, rushing hither and thither with their boards covered with the weekly supply of bread: after seeing a bread-baking such as this one can well realise the point of a riddle popular in these parts :--

Q. A black-faced heifer which devours brushwood? A. An oven.

Towering above the town is a pointed cliff forming the summit of that wall of precipice which rises straight out of the sea. On the summit of this cliff is perched the remains of a castle, which once belonged to the dukes of Naxos, and all that is left of the old Hellenic town. This is I,I60 feet above the sea, but what one chiefly sees now are Roman remains, cisterns, and walls. Into the bell tower of a large church half-way up the hill, dedicated to the Assumption of the Virgin, is let the torso of a Roman figure, and in the church itself there are traces of old pillars. Part of the modern cemetery is bounded by an old Hellenic wall, just below 
this church; and a wretched cemetery it is, with only rough stones without an inscription to mark the graves. In a ruined church at the top of the cliff is an inscription of the date of Tiberius, and below, near the town, is an Hellenic one, two centuries B.C. A few remains here and there have been found, but all point to Pholygandros in ancient days having been a very insignificant place. far inferior to Sikinos, and very sparsely inhabited.

It was a most enchanting day that we chose for a visit to the golden grotto of Pholygandros. Out of politeness the demarch determined to go with us; he had never been inside it he said; and I feel convinced that our rebukes urged on this energetic but misguided man to undertake a task for which by reason of increasing years he was totally unfitted.

We rode down the demarch's newly paved mule road to the southern harbour, and there beheld the maritime importance of Pholygandros as compared with Sikinos. They have four caïques belonging to them, and lots of fishing-boats, and the harbour, though small, shallow, and exposed to the south, is deserving of the name. A small colony of fishermen's huts forms the port, and here we noticed a clever little contrivance which they fasten to their nets in rough weather so that they may know where to find them. A bell is hung from two bent reeds, which form a little dome built on some flat reeds, and around the bell hang stones which strike it when the sea is rough. Here, as elsewhere, we were struck by the universal use of the gourd for all domestic purposes. A gourd with a long handle they will put on the table for a decanter; small gourds cut in half serve as wine-glasses; gourds with handles are used by every fisherman for baling water out of his boat; they are used for floating nets, and likewise for 
sieves through which milk is passed: a hole is made at one end, and a piece of the equally useful brushwood is stuffed into it, then the milk passes through the brushwood and is strained. Gourds properly prepared are used almost exclusively for the carrying of wine on a journey, and replace bottles in a country where the wine is quite a secondary consideration ; for you pay threepence for your bottle and perhaps a halfpenny for the wine that is in it.

We got into a small boat at the harbour, and were rowed all along the wonderful line of cliff to where the grotto is ; a cliff which rises I, I60 feet straight out of the sea, without a break or a ledge to catch the eye, is by no means a common sight, and this cliff extends thus for fully two miles. The formation is limestone streaked with iron, and here and there a few tufts of green relieve the monotony, the whole contrasting wonderfully with the indigo colour of the sea under its widespread shadow. Arato, an old writer, tells us that Pholygandros was once called 'Iron,' and that its second name was taken from a son of Minoa, of Crete; it well deserves the name of Iron, for this wall of cliff is like a band of rusty iron coming out of the sea. We were rowed close up to the grotto, the entrance to which is about thirty feet above the sea, and thirty feet of apparently horizontal rock.

It was much easier to tell why it was called the golden grotto than to get into it, for the iron in the surrounding rock makes it look like a black picture set in a frame of gold; but our climb to it was fearful, and the energetic demarch won our infinite respect by ultimately accomplishing it. Anciently this grotto was approached by steps from above, which are now worn away; they led up to the old town on the cliff, and their 
existence was discovered in 1837 by Kyrios Latre; but now the only way of reaching the grotto from the landside is by being let down by ropes for unpleasant distances.

Inside the grotto is curious and adorned with stalactites, like cathedral stalls, but nothing worthy of admiration after one has seen the grotto of Antiparos ; inside, however, it has some ancient cisterns, which interested us, still full of water, and the haunt of countless pigeons. There are three of them-one round, one square, and one semicircular-and appearances point to its having been a place from whence the inhabitants in times of siege could get their water; also it appears to have been used as a cemetery, for rows of tombs have been found here and marble statuettes. We turned over the thin sandy soil with which the bottom is covered, and found quantities of ancient broken bits of pottery of a coarse description; and it struck me as a place that might repay a little excavation.

It was all very well to have climbed up-the descent was quite another thing. I would almost warrant that the demarch had never been so terrified in his life as he was then; our two sailors helped him down slowly by steadying his tottering steps and finding foothold for them. Beads of perspiration stood on his brow when he reached the boat, and if future travellers visit the golden grotto of Pholygandros I feel confident that he will not attempt to accompany them, but remain prudently in the boat below.

Pholygandros is an island of most extraordinary shape, and if we had not Arato's authority for deriving its name from Minoa's son we might be tempted to speculate that it had something to do with a polypus, for 
the $h$ is oniy a modern innovation. From the central height of the island legs stretch out into the sea in every direction, and this central height divides Pholygandros into two parts, one of which is a perfect wilderness of stones and the other very fertile, possessing smiling valleys and mountain slopes cultivated up to the very summit.

Of course the highest mountain is called Mount Prophet Elias, and close to it is the summit of St. Eleutherios, with a little church dedicated to that saint at the top. When there is a drought all the Pholygandriotes with the priests and the sacred pictures of the Madonna walk in procession first to the top of Mount Prophet Elias, where they kneel around his shrine and pray for rain; after which they go and do likewise at the shrine of St. Eleutherios. "There is quite a little historical interest associated with our Church of St. Eleutherios,' old Themistocles Mavrojenes said to me that evening. 'Seventy years ago there lived a pirate who annoyed the Pholygandriotes excessively. They prayed and prayed to St. Eleutherios for his death, and vowed a church to the saint's honour whenever that event should take place. The pirate, however, would not die, and for many years continued his depredations, until at last, at a ripe old age, he was gathered to his fathers; and our townspeople, who evidently think that no limitations can be brought to bear on the answering of a prayer, felt in duty bound to erect a church. It is a wretched little concern, however,' concluded Mavrojenes apologetically; 'if he had been more prompt in his succour St. Freedom would have had a better temple erected in his honour.'

The day before we left Pholygandros was a very gay one for us. Themistocles Mavrojenes, being a privileged person and decidedly shrewd, managed to keep in with 
both parties, and was the bearer of a message from the hostile camp. Dr. Venier presented his compliments to us and expressed his regret that, his relations with the demarch being so strained, he could not possibly give himself the pleasure of personally paying us his respects, but should be delighted to welcome us in his own house.

Dr. Venier lived in the 'Inside,' in an old-fashioned house, and from him we learnt the sad truth that under the present horrible rigime all the delightful old customs and costumes were being abandoned. 'Twenty years ago you could not have seen quainter customs than here in all the archipelago, and now even Sikinos beats us.' But I replied, in the words of the demarch, 'Pholygandros is a little Paris as compared to Sikinos,' and I was sorry I did so, for the ground on which I was treading was treacherous; for the future I decided to leave Greek politics alone.

Only some of the richer inhabitants, and amongst them Dr. Venier, have kept their old dresses, ornaments, and lace; the poorer people have by this time sold all theirs, and Dr. Venier showed us some very lovely things. The ancient headdress seems to have been the same as that worn still in Siphnos ' and is also called the pina: besides this Dr. Venier had some exquisite gold and silver lace and lovely silk embroidery which should be in a museum. On King Otho's visit to Pholygandros he was entertained by Dr. Venier's father, when Dr. Venier was still a boy, but he remembered quite well that Queen Amalia had said that she had not slept all night for admiration of the lovely embroidery with which her bed was hung. Dr. Venier showed them to us, with pride, as articles which royalty had used. The curtains were made of striped silk gauze, with gold 
lace insertion; the pillow-cases were of red silk edged with gold lace; the sheets were edged with some of the same gold lace, only wider; and as for the coverlet, it was made of the richest brocades I ever saw. The valances and bed-tops were all hung with old Greek point, but then the room was a tiny, ill-lighted hole, which a servant in England would turn up her nose at. I do not wonder that Queen Amalia did not sleep.

After a pleasant afternoon spent in the company of the Veniers, we returned to our host's house, and went into spiteful raptures over the beauty of Dr. Venier's embroideries. It was in vain that the democratic demarch smiled and said that they cared for none of those things, his wife's jealousy was thoroughly aroused and told a different tale. She went to her cupboard and produced all she could find of lace and embroidery; but, alas! her stock was very inferior to what we had seen.

This is always the way to see and hear anything in these islands. Tell everybody the beautiful things you have seen and heard in other islands, and you are sure to arrive at the best they have. Jealousy is wonderfully developed in these parts.

That evening old Themistocles Mavrojenes gave us an invitation to ' a table' at his house in the 'Inside'; so when it was dark we sallied forth to our meal, with the aid of a lantern. The domestic who conducted us was not accustomed to dinner parties, and led us through the kitchen, to Mrs. Mavrojenes' dismay, who was giving the finishing touch to her dishes of risoglio; our host was very angry with the man, and set to work to talk about his distinguished ancestor, the prince of Wallachia.

We did not fare at all badly, and for the first time in 
the islands did our hostess sit at the top of the table, in European fashion. We had soup, and the meat which had been boiled in it, served up with tomatoes. We had

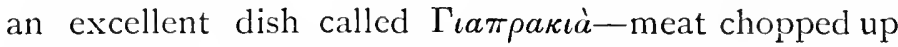
with a little rice, onions and spices, and then wrapped up in vine leaves, which they keep in pickles for this purpose-over it was thrown a delicious sauce of egg and lemon.

Courses of cold fish (cuttle-fish, and red mullet) followed next, and then came the rice and milk pudding (risoglio), with an elaborately stencilled pattern of grated nutmeg on the top. These dishes and lots of little plates containing olives, capers, \&c. were scattered about to adorn the table all the while. It was quite evident that Themistocles Mavrojenes knew how things should be done as behoved the descendant of so illustrious an ancestor.

Wine passed plentifully enough during dinner, but with dessert Greeks never drink wine, but crack their walnuts and munch their almonds with nothing to wash them down. Long before the meal was over guests began to troop in, and were very grateful for occasional handfuls of almonds, raisins, and nuts which our hostess passed to them from time to time; finally, we wound up the entertainment with a gencral smoke and cups of Turkish coffee.

Next morning we left Pholygandros, and were surprised to find our boat, which hitherto had had a white sail, now with a rich coloured one; the boatmen had found some red mud, in which they had dyed it their favourite colour. Certainly it looked very picturesque, and contrasted well with the green boat. Another surprise awaited us in the shape of an old woman and a big box; we expostulated a ittle, saying that we had 
hired the boat for ourselves; but they said there was so little opportunity for her to get away that she should be treated as ballast, and so forth; so we made no further objection. They shoved her and her box on board with little respect, put her into a dark and stinking hold with our servant, and fastened the lid down. We heard nothing more of her until we arrived at our destination, except terrible yells and groans when it became rough, for the Greek island women suffer more audibly from sea-sickness than any people I am acquainted with.

Our voyage was a very characteristic one in these islands. We planned to go to Antiparos, and we started with a favourable though slight breeze. This died away altogether before we got an hour on our way; the exceeding heat of the sun, and ominous clouds on the horizon, made our sailors anxious about the upshot. We said we would sail for Amorgos if possible, and started in that direction; for the breeze was freshening from the west. Before very long the breeze became too fresh, and our men insisted on running for Ios; but we found we could by no means go round the northern point of Sikinos, so we had to retrace our way almost back to the harbour of Pholygandros.

It soon began to blow with a vengeance; it was impossible to make for Ios. 'Let us run for Santorin,' we said, getting more and more disgusted at our fate. But no; hardly had we gone a mile than our captain said it would not be safe; we must put in to Sikinos, on the southern side. What horrors! were we again going to be storm-stayed at Sikinos? We thought of the demarch's damp house and the cold and misery of the place. We saw, to our delight, the Sikinos caique put off and make for Ios. 'Surely,' we said, 'if that craft can go we can ;' but it 
put back again almost immediately, and our hearts sank within us.

In our despair we implored our captain to make an attempt to reach Ios, and, the weather having taken a favourable turn, he promised to try. Though much tossed about and drenched with the waves, we reached our haven in safety shortly after Io o'clock, after a day's bitter experience of the uncertainty of caïque-sailing. It is impossible to make any plans beforehand in the winter time; it is not where you will go, but where you can get, when amongst the islands where steamers do not touch.

Our good friends at Ios were delighted at our return, having had a prognostication of it, and entertained us hospitably till the steamer came to carry us away. 


\section{CHAPTER X.}

THE DEATH-WAILS OF MYKONOS.

Everywhere in the Cyclades we were told that when we came to Mykonos we should hear the best lamentations over the dead that exist in Greece: that barren Mykonos had this one unenviable speciality ; nowhere else could the wailing women ( the dead such stirring, heart-rending dirges as there. So we went to Mykonos with the firm determination of waiting there until somebody died, and in the cold changeable days of March we did not anticipate that we should be long delayed.

We crossed over from Syra in the tricandira of a Hydriote fisherman ; and good cause we had to be thankful that we had chosen these sailors and their trustworthy boat, for the sea was lashed angrily by a southern gale, and unpleasant thoughts occurred to us that our purpose in going to Mykonos to hear a death-wail was an illomened one, and might end disastrously to ourselves. But the boats from Hydra are good; they have osier instead of canvas bulwarks - wattled osiers, the ' $\lambda$ vyapia which grow in mountain streams, ${ }^{1}$ and which, I think, must have formed the bulwarks which Ulysses made for his two-decked raft when he left the charmed island of Kalypso. Two islands in the Egean Sea (Hydra and IVide p. I4I. 
Psara) still have these bulwarks, and these boats are the best. We had to take down our sail half-way, and put up a smaller one, which was an unpleasant process in a pitching sea; but we had time to admire our primitive sail-rings, which were made out of cow's horn cut into rings. Elsewhere we had seen vine-tendrils used for this purpose; but they are not nearly so satisfactory, for whenever a good gust filled the sails one or two were sure to give way.

The view of Mykonos from the sea is attractive: it is a considerable town composed of white houses, with wooden balconies, which are built for the most part on a promontory which juts out into the sea. A regiment of windmills coming right down the hillside forms a conspicuous object from afar, and dotted about here and there are some of those quaint dovecotes of which we afterwards saw better specimens on Tenos. At the end of the promontory is all that is left of a mediæval tower which once protected the harbour. There is a Byzantine church, buried in houses, and there is a tall, gaunt house, of peculiar structure, built by the Russians in 1777 , who intended to make Mykonos their headquarters in the Cyclades. This house has now come in very well for Government purposes-it serves as the demarcheion, and the public school is held in it. Some of the houses of Mykonos are well built and more decorative than is usual in these island towns ; many of them have quaint chimneys, with brick patterns, and a dove at the top-something quite original in house architecture.

In the middle of the harbour, joined to the quay by an arched bridge-recalling a Venetian canal bridge to one's mind-and built on a rock, is a little white church, with vaulted roof, dedicated to the modern Poseidon, St. Nicholas. Here the sailors worship their patron 
saint, and at Mykonos nearly every household possesses a sailor amongst its number; consequently St. Nicholas and his feast are in high repute. In our bedroom was an eikon of St. Nicholas painted on the inside of a crab's shell, the back of which was gilded; and the sailors here have many songs about their patron saint : how he has saved them in the hour of need; how he invented the rudder; and how he sits at the helm, whilst Christ is in the bows, and the Virgin in the middle of his boat.

Our first friend in Mykonos bore the high-sounding name of Paleologos; it is a common one in the islands. Once we had a muleteer who bore the name of the last line of Emperors of the East. He gave us coffee, and was very specious; but our second and staunchest friend was Demarch Kalogerás, which being translated means 'Monk.' The Monks have quite a mansion by the shore, and a pleasure garden on the hillside; they live in European style, and Demarch Monk, as the sovereign lord of Mykonos and the adjacent Delian isles, has somewhat to say to excavation, and jealously guards the treasures which have come from Delos in a dingy museum in a back street, of which more anon. Everybody in Mykonos has a little museum-scraps of marble let into their houses, a few lamps, coins, and other treasures which have come from the neighbouring mine of antiquities.

It cost me much trouble and thought to introduce the subject I had at heart. I spoke of the changeableness of the weather, the prevalence of pulmonary diseases at this season of the year, and so forth ; if it had been a wedding, or a christening, or a dance I had wished to study, there would have been no difficulty about it; but to have to admit that my cherished wish was to attend a Mykoniote 
funeral was a rery delicate subject; I never felt a more heartless wretch.

After a little mancuvring I learnt that two or three Mykoniotes were in extremis; that a young Mykoniote had lately died at Athens, and that the family were detcrmined to have the customary lamentation for one who had died abroad (' $\xi o ́ \delta \iota$ or $\dot{\xi} \xi o \delta \imath \grave{s} \theta \rho \hat{\eta} \nu 0 s$ ). Nobody could be kinder than Mrs. Monk when she had once warmcd to the subject, evincing considerable pride in describing what I was pleased to call the speciality of her island; and from my conversation with her I learnt much about a Greek's conception of death.

The idea of death in the mind of a modern Greek is distinctly pagan : death to them is solely the deprivation of the good things of this life; their minds do not seem to be capable of looking forward to a future beyond the 'dark grave' and the 'black earth.' Hades is the destination of the dead, Charon is their ever-watchful guardian; punishments for sin are carried on in Tartarus,

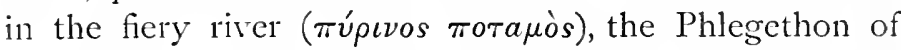
antiquity. Christian teaching has adapted to itself rather than obliterated ancient myths. The great authority for all the horrid frescoes and ideas represented in the Greek Church is derived from that wonderful document entitled the Apocalypse of the Virgin, in which it is related how the mother of Christ was one day engaged in prayer on the Mount of Olives, and conceived a desire to see the chastened in hell. She asked St. Michael to take her, and as he conducted her he explained the punishments and crimes of each person they there met. The archangel Michael is the modern Hermes, the angel of dcath, and in the representations of him, usually to be secn over the door entering into the part of the church consecrated to the sacred mysteries, he is depicted as a 
warrior having in his right hand a naked sword, balances in his left, and trampling a sinner under his feet. Again the idea is prevalent that at a man's birth the Fates fix the day of his death ; consequently the pious believe that on November 8, the archangel's day, he looks through the list and writes down on a tablet the names of those who during the ensuing year must fall victims to his two-edged sword.

From the lamentations ( $\mu$ oıpodóyıaı) which are sung in Greece to-day we can learn much about the popular beliefs concerning the condition of the lower world. If you read in Passow's collection the song of the dying 'klepht' Zedros your mind is at once carried back to the sentiments Sophocles puts into the mouth of the dying Ajax.

Charon, or Charos, to-day is a synonym for death. 'Charon seized him' is a common expression, and a clever popular enigma likens the world to a reservoir full of water at which Charon, as a wild beast, drinks ; but the beast is never satisfied and the reservoir never exhausted. Imagination is the soul of these modern Greek death ballads; the ideas are beautifully poetical in many cases, though the language is crude and often difficult to follow from the complexity of patois expressions. They sing to you of feasts and banquets in Hades, where the dead are eaten for food; they tell you of the gardens of Hades, where the souls of the departed are planted and come up as weird plants.

King Charon is not the Death of the middle ages, the skeleton with a scythe in his hand; he is the Homeric ferryman; he rows souls across to Hades in his caĩque, and he is a hero of huge stature and flaming eyes of

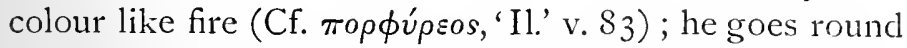
to collect the dead on horseback: so in olden days a horse 
was the symbol of death, as we see on so many tombstones. Charon, too, can lurk in ambush to surprise his victims, and can change himself into a swallow, like Athene, who perched on Ulysses' house on the day of the murder of Penelope's suitors. Charon's palace in Hades is decorated with the dead, and the bones of the departed are used for every purpose of domestic use. The dead who haunt it are for ever planning to return to the upper air, and form schemes for so doing, which Charon always discovers; sometimes they even manage to steal his keys, but in vain.

There are traces of Lethe, too, in the lamentations of to-day - a river of which the dead drink, and forget their homes and their orphan children. There is found, too, a parallel case in animal life; a shepherd will tell you that there grows on the mountains a herb called 'the grass of denial,' and when the flocks have eaten thereof they forget their young.

On the second morning after our arrival at Mykonos we heard that young Parodos was no more; that he had left a wife and several small children. A very sad case it was, carried off, as he had been, in the prime of life by a consumption, of some ycars' standing, which had been brought to a climax by this damp and windy winter. Mrs. Monk, with feminine minuteness, entered into details of his last hours. He had received the prayer oil ( $\varepsilon \dot{v} \chi \varepsilon^{\varepsilon}$ $\left.\lambda a \iota \nu^{\prime}\right)$, she said, in the middle of the night, with the customary attendance of seven priests to bless it. Very early in the morning, feeling that he was sinking, he summoned his family around him and sprinkled them, as is their wont in Mykonos, with water in which salt had been cast, saying, 'As the salt has melted so may my curses melt.'

' The agonies of death were short; he passed away as a 
burnt-out candle,' said Mrs. Monk with a contented sigh ; 'so we have no fear of his dying unpardoned.' 'Why so ?' I asked; and she spoke disdainfully of a religion which does not teach that, if the agony of death is prolonged, all know that the sufferer has been unpardoned for some injustice, in which case, if possible, the injured man, if alive, must be summoned to forgive, or if dead, the man in the death agony must be fumigated with the smoke made by burning a portion of the other's shroud.

The bells of Mykonos were tolling mournfully, to tell of the death of the young man; and I shuddered involuntarily now that I knew that my desire was to be realised. I was to be present at a marologia over the dead.

'The women are preparing the corpse now; by ten o'clock all will be ready,' Mrs. Monk gaily suggested as we were discussing some eggs and boiled milk for breakfast. 'The marologista Zachara is engaged to sing, and no one is better suited than she for her occupation.'

We then talked about these women: how they practise their dirges when working in the fields; how they have certain verses and certain stock ideas for nearly every emergency; and how by constant practice it comes quite easily to them to make impromptu verses about the special case in question. A few years ago they used to send to Mykonos from all the islands round when a death occurred at which a special honour was desired to be shown to some deceased magnate; but lately this custom has been abandoned. It must have been a weird sight to see the woman dressed in the peculiar costume of Mykonos, the tall makramades head-dress, on her way to a neighbouring island to sing her wail.

The makramades when black is a peculiarly hideous 
and forbidding headgear, being a tall block of wood or stiff canvas, which is placed on the top of the head and bound round with a towel ; round the forehead is wound another towel ${ }^{1}$ or handkerchief, which secures the head-dress firmly, and the ends of which stick out curiously on either side of the face. Two curls appear on the cheeks from under this. Of course, as suited to her calling, the morologista has to wear this black; other women have coloured and embroidered ones, which are by no means so repulsive, especially when worn with the dress to match it. They have blue jackets edged with ermine, a red handkcrchief round the neck, a gold triangular stomacher, and yellow wristbands, a common cotton petticoat and velvet shoes with white lace edges. This costume is, alas! now a rarity ; we saw just a few old women wearing it, but when they are dead there will be no one to take their place. In a few years the makramades of Mykonos, the tourlos of Amorgos, the pina of Siphnos-the last relics of those costumes which were different in every island-will be swept away and forgotten.

'We Mykoniotes are deeply attached to our marologia,' remarked Mrs. Monk with pride. 'My uncle, who was a merchant at Marseilles, and who died there, was determincd to have one at his death, and he asked his wife to sing one over his corpse. She, poor woman! pleaded that she had been so many years in a foreign country that she had quite forgotten what to say and clo. "Go fetch my ledger," said the dying man sternly; "there you will find put down all I have earned. Sing that!",

In answer to my enquiries Mrs. Monk told me how they treated a corpse in Mykonos: the funeral takes 
place as soon as possible after death-generally within a few hours-the dead body is washed in water and wine, then the deceased is wrapped either in a shroud or dressed in his best clothes and placed on a bier in the middle of the outer or reception room of the house, his face is turned towards the east, his hands across his breast, and his feet are bound together with black bands; and at his head and feet stand two lamps adorned with coloured ribands. The bier is covered with flowers, out of which the wax-like face of death peers in hideous contrast.

When everything was prepared the kinsmen and friends of the deceased man were summoned to attend the lamentation by the bellman, and amongst the others I wended my way to the house of mourning, feeling heartily ashamed of myself for intruding on their grief: but at the same time I was fortified by a consciousness that the Mykoniotes were flattered at the notice taken of their custom.

The marologista Zachara came in shortly after in arrived; the kinswomen were all seated around the corpse ; the afflicted widow and her children were groaning audibly on the divan, and had their hair down ready for the customary tearing and shaking. The entrance of Zachara was the signal for the commencement of that demonstrative grief in which the Greeks love to indulge: they all set to work to sing in mournful cadence about the merits of the deceased, keeping time with their feet and beating their knees with their hands; then suddenly, with a fearful shriek, the widow went off into an ecstasy of grief. She tore her hair, she lacerated her cheek, she beat her breast, she scratched her bare arms, until at length two or three women rushed forward to restrain her in her extravagant grief; her poor little children lay 
crouching in a corner, terrified beyond measure at what was going on and screaming with all their might.

At length Zachara, who hitherto had taken no part in the proceedings, but had stood in a statuesque attitude with a well-feigned face of poignant grief, as if contemplating the misery before her to inspire her muse, now rushed forward, fell on the corpse, kissed it, and rose to commence her dirge in that harsh and grating voice which the Greeks love, but which is so distasteful to Western ears. Thus she began :-

I yearn to mourn for the dead one Whose name I dare not say, For as soon as I speak of the lost one

My heart and my voice give way.

As she reached the end of this stanza her voice trembled, she paused for a moment, as if to regain her composure, during which time nothing was heard but stifled sobs.

Who hath seen the sun at midnight?

Who hath seen a midday star?

Who hath seen a bride without a crown

Go forth from her father's door?

There was a dead silence now, the widow's groans were hushed, the beating of the feet was stopped, the pause was one of half-curiosity, half-suspense, for all knew that the terrible climax was coming as Zachara lifted up her voice again and wailed:-

Who hath scen the dead returning,

Be he ling or warrior brave?

They are planted in Charon's vineyard,

There is no return from the grave.

This was Zachara's prologue, and after it the grief and lamentations were renewed with fresh vigour. So far 
doubtless, many of the mourners had heard before on similar occasions, for it was one of her stock pieces; after this she had to deal with the special case of the deceased. She sang of the loneliness of the living, of the horrors of death, and in that strange language of hyperbole she wondered how the sun could venture to shine on so lamentable a scene as the present. During all this time the widow, the kinswomen, and the children were wild with grief. Nature at length asserted herself and demanded a pause, during which the company refreshed themselves with raki, biscuits, figs, and other small refections which had been laid out on a table in the corner of the room.

Then the tide of grief flowed on again; in fact, a Greek lament is one of the most heart-rending scenes that can be witnessed if one were not somewhat fortified all the while by an inward consciousness that much of it had been got up for the occasion, and that mourning such as this, which is repugnant to our stolid northern nations, is usually as evanescent as it is intense.

Presently another well-known marologista dropped in, who, we learnt, was a relative of the deceased; but why she had not joined the company previously remained a mystery. She and Zachara then sang verses alternately, and together they reminded one forcibly of the Carian women of antiquity who were hired for the same purpose; and one's mind wanderęd back to a Greek chorus-that of Eschylus especially - where the virgins at the gate of Agamemnon indulge in all the most poignant manifestations of grief, beating their breasts, lacerating their cheeks, and rending their garments; and I could not but admire the prudence of Solon, who forbade the excessive lamentations of women (Plut. 'Sol.' xii. and xxi.)

This prolonged agony of mourning continued for 
two long hours; occasionally to relicve the paid lamenters, some of the kinswomen would take up their parable and sing a verse or two, sending messages of love and remembrances to friends who had gone before to the shades of Hades; and great was my relief when the pricsts arrived with their acolytes bearing the cross and the lanterns to convey the corpse to the grave.

Before lcaving the house it is customary to break a jug of water on the threshold: they spill water when anyone goes for a journey as an earnest of success; now the travcller had gone on his long journey, and the jug was broken.

It was not far to the church, so that the funeral procession did not take long. The bier, with the corpse exposed, was carried by four bearers; the priests chanted the offices as they went; and occasionally the lamenters, who headed the procession, broke forth into their hideous wails. And as it passed by women came forth from their houses to groan in chorus with the others. It was, indeed, a painful sight to witness.

On reaching the church the corpse on the bier was laid just inside the porch; and when the priests began the liturgy the mourners ceased to wail for a time. Then came the impressive and very solemn stichera of the last kiss, which was chanted by all the priests together-'Blessed is the way thou shalt go to-day, \&c.'whereat each mourner advanced and gave the last kiss to the cold face of the corpse, after which all with one accord burst forth again into extravagant demonstrations of grief. Finally, the corpse was lowered, without a coffin, into its shallow gravc, and each bystander cast a little soil into the tomb. Only the rich have coffins; in fact, the poor have a prejudice against them, for three years after interment the bones are dug up 
again, washed, and cleaned, and put into the charnel house ; and if by any chance the flesh is not decayed off them the people think it a terrible proof that the owner of the bones has not been allowed to rest in peace-he is still a poor wandering ghost.

When a death has occurred in a house they thoroughly purify the place, and on the return of the mourners from the funeral they wash their hands. Many superstitions concerning death still exist, but they are becoming fewer year by year; for example, the dying must not have a goat's hair coverlet over the bed-it will impede his departure-and a child should not sneeze whilst a lamentation is being sung, for it is considered as a portent of its approaching death; only by tearing off a portion of its dress can this disaster be averted.

In most places it is considered wrong to cook or perform household offices in the house of mourning, so friends and relatives come laden with food and lay the 'bitter table,' as they call it (just like the $\nu \varepsilon \kappa \rho o ́ \delta \varepsilon \iota \pi \nu a$ of ancient days); and for three nights after a death, on the pillow which the departed used they burn a dim lamp, because it is thought that for three days after burial the soul loves to revisit those in his old home, and busies himself with his usual avocations.

On the day following the burial they prepare the $\kappa o ́ \lambda \lambda \nu \beta a$ at Mykonos; that is to say, boiled wheat adorned with sugar plums, honey, sesame, basil, or whatever other delicacy may suggest itself to the survivors. Sometimes they call these 'blessed cakes' ( наки́pıa)—out of euphony, no doubt-and on the third day the friends and relatives reassemble, again being summoned by the bellman, fresh marologia are sung, the grief scenes are re-enacted around the delicacies they have prepared, and after a sufficiency of lamentation they repair to the 
tomb, put the $\kappa o ́ \lambda \lambda v \beta a$ upon it, lament a little more, and finally distribute the eatables to the poor at the church door.

The same ceremony is gone through again on the ninth and fortieth days after death, and again also on the memorial festivals at the expiration of six and twelve months, and rarely, too, on the second anniversary; in some places I have often seen tall pots like chimneys dotted about in churchyards where incense is burnt in honour of the departed on stated occasions. These and other ceremonies, recalling the ancient feasts to the dead, are still extant in the islands. At Thermià, after a funeral at the tomb, they distribute sweetmeats and raki, and again they do the same after the distribution of the $\kappa o ́ \lambda \lambda v \beta a$ : this they call $\sigma v \gamma \chi \omega$ ' times, also, on the Saturday after the death, when the. bread-baking takes place, warm bread with cheese or oil is distributed to poor women at the ovens in memory of the departed, and if the death has occurred during Lent or Easter Day flesh of lambs and wine are given in charity by wealthy mourners.

Such was the death and burial that I witnessed at Mylionos ; a scene which, for its intense painfulness, will never be effaced from my memory. For days after the cries of grief rang in my ears and haunted my dreams, but Mrs. Monk, in her matter-of-fact way, said, 'Everyone must die, and everyone at Mykonos, when he or she dies in the prime of life, must have a marologia sung over the corpse. It is different when a worn-out old man or woman dies; nobody thinks it worth while to mourn for them. You must go to-morrow and hear the other lamentation over the poor young fellow who died at Athens.'

I rather demurred; one marologia will last a long 
time, I thought; but Mrs. Monk persuaded me by saying that when anyone dies in foreign parts, unaccompanied to his tomb by his relatives, it is a solemn duty to show extra attention to his manes at home. Formerly a lamentation such as this could last forty days, but now it is limited; they wail and cry for a few days, and when they are exhausted they give it up like sensible people, and do not wear themselves to death with grief, as once they used to do.

It was to a little back street of Mykonos to which I was conducted next morning, and long before reaching the house we heard their wails and lamentations; and as I entered my breath was almost taken away by a young girl, with her black hair streaming over her back, her face distraught with grief, rushing violently at me, screaming, 'Bring me back my brother!' With difficulty her kinsfolk persuaded her to leave me alone and to resume her seat, and as soon as I recovered composure after this rather embarrassing adventure I recognised that she was the chief mourner, whose duty it was to exhibit every possible excess of woe. She screamed at the top of her voice, she gave violent tugs at her hair, she beat her breast with crossed hands, she stamped her feet, she scratched her arms until they bled; and all the while her kinswomen sat around her singing dirges in a low, monotonous voice, as if they had to squeeze them out by pressing their hands to their sides and beating their knees vigorously, and then pausing every now and again for a good, honest cry. When the poor sister's grief was too violent, when she bade fair to do herself some serious bodily harm, the others rushed forward to soothe and restrain her; and a poor little girl of about ten, a younger sister of the deceased, would rush up from time to time and clutch at her dress in a terrified manner, asking her 
if she did not love her just a little, if all her affections had been centred on the departed.

Now and again the grief would subside, and then it was the marologista's turn to do her part to rouse up fresh anguish in their breasts.

My eyes to-day are streaming,

My grief is bitter and sore,

For he's gone his long, dark journey ;

His home shall know him no more.

The one redeeming feature in this scene was the absence of the corpse ; the women were just seated round the room on chairs, with an empty space in the middle where the bier would have stood. There were no men there, and some few I spoke to outside seemed, I thought, to sneer a little at this lamentation for a dead man who had died away from home. And I do not think Demarch Monk was plcased with his wife for inciting me to go.

Now for a few words about Mykonos. In itself it is one of the least interesting islands of the archipelago. 'Lowly Mykonos,' as Pliny described it, is a fair description still. There are next to no remains of antiquity upon it, and now it is scarcely possible to make out where the two cities mentioned by Skylax stood. One must have been where the present town now stands, judging from the slight traces of walls and graves; and the other very likely was near the harbour of Panormos, a bay which runs right into the centre of the island, and near which there was a necropolis. Beside these insignificant traces, and the remains of a watchtower, all the glory of Mykonos is reflected. Every possible piece of antiquity comes from Delos, even the pillars down by the harbour to which the sailors moor their boats are from a temple at Delos.

Like all other travellers who have visited Mykonos, 
one of our objects was Delos. I should think that it has hitherto been the traveller's only object; consequently, as Demarch Monk argued, it is only right that antiquities dug up at Delos should be kept for inspection at Mykonos, the nearest town, and the only one in the demarchy in which Delos is situated, and not be removed to Athens, as archæologists wish. This system of treating antiquities, now general in Greece, must be looked at from both points of view: it is charming to see local antiquities in local museums, where the associations are so much keener, and travellers are thereby attracted to a spot they would otherwise not visit, and spend money which would otherwise not find its way there. This system may prove excellent in Western Europe, but in Greece, where accommodation is outrageously bad outside Athens, the case is different. How can people come to Mykonos? Unless you are armed with a letter of introduction, there is no possible means of obtaining a night's lodging. The steamer comes only once a week, when the weather is fine, so a traveller who visits Mykonos, and would not stay a week on this uninteresting island, must depend on the precarious passage by caïque.

Furthermore, the pleasure felt by the people of $\mathrm{My}$ konos in possessing the valuable remains of Delos is only that of a satiated dog with a bone; they do not want them or understand them themselves, so they try to prevent anyone else from reaping the good that would ensue from their being properly looked after and opportunity given for a more thorough study of them. I append a note to this chapter on the museum at Mykonos.

We only made one expedition in Mykonos, and that was to a convent in the southern part of the island. It 
is four miles distant from the Chora, and at first the ground traversed is excessively wild, being covered with huge blocks of granite, which easily account for the legends of antiquity which relate that here Hercules and the giants fought, and that here they lie buried. It is an exceedingly wild, dreary spot, capable of suggesting any horror. But the southern part of the island, in the district called 'the upper part,' presents an unusually' prosperous aspect. It is all studded with homesteads in the midst of fertile fields, and there each husbandman lives at the scene of his work; so different to other islands, where the tiller of the soil lives in the town, and may have several miles to traverse every morning before reaching his daily labour. In the centre of this fertile spot is a prosperous monastery called Tourliani, or 'the little towers,' because hard by, on a rocky summit, was the mediæval fortress of Mykonos, of which now only the outer walls can be seen. It is a rich monastery, but possesses nothing old or remarkable save the miraculous eikon, said to be the work of St. Luke. and to have been found by some divers at the bottom of the sea. You can see nothing of it but a black mass, and a few years ago Archbishop Lycurgus, of Syra, wished to send it to an artist, so that it might be restored, and some expression given to it; but the people would not hear of it, and it was left as it is. On the top of a fine wooden throne, in Florentine carving, the man who founded the monastery three hundred years ago had himself placed; beyond this there is nothing of interest.

Close to this convent was a nunnery, now discstablished. 'In former years,' said an irreverent peasant who showed us the way, "the convent and the nunnery were the only houses existing in this part of the 
island; and a fine time they had of it, you may be sure.'

Our excellent quarters with Demarch Monk and the charming society of his family made our evenings at Mykonos pass very pleasantly. Mrs. Monk produced all her treasures for our inspection-glorious old Greek lace enough to constitute a small fortune in England, jewellery of Venetian date, quilts made out of lovely brocades, and a square embroidered piece of old chenille, which was used as the family pall to place the coffin on ; for the Monks are rich, and, when they die, they go in for this luxury. The daughters in their room upstairs had an enviable little museum of treasures from Delos. Altogether we had much to see and envy, and felt grateful to Mrs. Monk when she gave us the eikon of St. Nicholas inside a gilded crabshell, adding gracefully, as she did so, that she hoped it might secure us a safe voyage to our country.

The night before we left, an old woman, called Marousa, was summoned to the demarch's house. She was a great hand at magic art, and told us wonderful stories, with the aid of a pack of cards, about ourselves ; stories which, beyond a doubt, she had culled from the gossip, which convulsed Mykonos just then, about the English who had attended morologice and had visited Tourliani. 'Marousa knows how to mix infallible love potions,' said Mrs. Monk when she had gone; 'but she would not tell you, however much you asked her.' But Mrs. Monk herself was more kindly disposed, and told us how a love-sick girl could win the object of her affections. "She must get the milk of forty mothers and of forty of their married daughters ; if she can do this, and if she can succeed in getting her young man to taste just a drop of this mixture, he is hers for life.' 
We were on the very best of terms with Mrs. Monk, and her tongue flowed freely about her native isle; it was with grief that we tore ourselves away next day on our way to Tenos.

\section{NOTE 1.}

On the Mussums of Mykonos.

There are two dark places in Mykonos devoted to the storage of curiosities, in one of which, little better than a cellar, are kept inscriptions of every sort ; in the other, which is lighted by two doors and two windows looking into a gloomy arcade, are kept the statues and sculptures. I will just mention a few of the objects therein because there is no printed catalogue, only an imperfect manuscript one, in modern Greek, which debars its use to many. There are numerous rude statues of Artemis, one of which M. Homolle dates at the sixth century B.C. It is a little less than life size, with the body enveloped in a long tunic, no sleeves, and fastened by a zone. She is crowned with a diadem, in which are nail-holes pointing to some decorations having been affixed; there are wings on the shoulders and heels, long pendants from the ears and hair hanging over the shoulders. There is evidently a desire to represent rapid motion, for the left knee, though to all appearances on the ground, does not touch it, and the wings are open. The face is full, but the legs are en profile. This valuable piece of archaic work stands in a dark recess, whilst the pedestal, with an inscription, on which the statue formerly stood, is placed at the other end of the room. Then there are five beautiful but much damaged metopes representing Hades carrying off Proserpine, all of the same character, and found near the same spot on Delos. These are said to be the work of the school of Prasiteles. Then there are those wonderfully large inscriptions from Delos, the largest known-eighty-eight inches long by forty-four-and covered with writing on both sides, detailing the wealth and possessions and the expenses attending the maintenance of the great temple of Apollo at Delos. Then we have a curious syren, of ancient workmanship, without a head, but with the long conventional curls still adhering to the back and chest. There is a very curious stele of Hermes, the head of which is gone, but all the pedestal is covered with every description of rude drawing, done at 
different periods; there are easily discernible on it dogs, fish, people, and a capitally executed goat, and a representation of the stele itself, so that we can tell what the head was like before it was broken off. Propped up against a pedestal in an awkward fashion is the somewhat destroyed figure of a warrior, the work of Agasius, of Ephesus, as we learn from the base on which it was found, and which is still on Delos; it was in the agora down by the sacred harbour, and is a finely executed statue of a barbarian, not of a Greek, as is easily seen from the helmet by his side. There is the headless body of Apollo, which the inhabitants of Tenea Orchomeno presented to the temple of Delos; there are the lionheaded water-spouts from the great temple of Apollo; and in a dark inner room are baskets full of lamps, jar handles, and treasures, which any other museum would prize, lying hurdled together in perilous confusion. The bottom of a plate, with the heads in relief of two Mœnads kissing, is one of the most exquisite examples of Greek pottery I have seen. Besides these things there are lots of smaller treasures in glass cases, the wheels of a toy chariot, a toy helmet-doubtless for votive offerings to the god-locks, utensils for domestic and temple use, all of which require far more attentive study than they are ever likely to get at Mykonos. When you visit Delos and see the vast acres of unexcavated ground, and know that the results of any enterprise must be deposited here, it is not encouraging.

\section{NOTE II.}

\section{The Excavations at Delos.}

It is a curious irony of fate that in a work on the Cyclades one is almost tempted to leave Delos out altogether. This islet, the centre, not only of the encircling Cyclades, but of the ancient religious world, has nothing whatsoever to do with the life of today, except that the harbour between it and Rhenira has been constituted a quarantine station. Delos and Rhenæa, now called 'the Deloi,' exist only as fossils, and any knowledge concerning them belongs almost exclusively to the French, whose active excavations, and the results thereof, have been so exhaustively treated by $M$. Lebègue, in his work, and by M. Homolle, in his articles in the 'Bulletin de Correspondance Hellénique,' that no comment is necessary. 
A visit to the excavated ruins with these works in one's hand is truly delightful; with their aid we were able to place all the buildings which have been alluded to by ancient writers, and we were furthermore able to picture to ourselves the scenes of bygone ages: the procession of white-clad maidens, which wound up Mount Cynthos to the temple of Jupiter and Minerva; the magnificent approach of the 'theories 'from Athens to worship at Apollo's shrine: and as we sat amongst the ruins excavated by the French we thought much of these things, for around us reigned a desolation and destruction perhaps more complete than that of Ninevel.

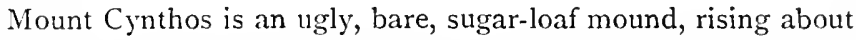
three hundred and fifty feet above the sea-level in the centre of the island, affording a scanty pasturage for goats; the rest of the island is tolerably fertile, and is let to a few shepherds for-what seemed to us a large sum in these parts - two hundred and forty pounds per annum. There are a few huts scattered about and a wooden shanty, where two old men live to guard the ruins from the descent of European pirates, who will go there in yachts and steal what they can find. All around stretches a vast sea of ruins, recalling Pompeii in extent and complete annihilation; you wander through houses with mosaic pavements, pillared halls with cisterns below, and the richness of marble wherever you turn is most striking, and in the brilliant sunlight almost dazzling. Much of the lychnites vein from Mount Marpessa of Paros has found its way here.

There is still a vast amount of work to be done on Delos if the Greek Government would only encourage enterprise in excavation. 


\section{CHAPTER XI.}

TENOS.

\section{The Panhellenic Festival.}

INASMUCH as the festival of Tenos is one of the greatest events occurring in modern Greek life, and since we visited the island expressly to see the festival, and not the island, on the first of our journeys there, I will here devote a separate chapter to the festival, and reserve another for the island.

Of the many existing points of connection between old and new Greece one of the greatest is the love of the panegyris: these religious festivals are still numerous in Asia Minor and in the islands as of old, and are characterised now as then by a mixture of devout earnestness and general sociability.

In every branch of life the religious susceptibility of the Greek of to-day is as it was when St. Paul wrote of them as being too superstitious, too devoted to the countless gods of their country. In short, this country, the former hotbed of polytheism, has in no way changed its character yet. They are as superstitious about the spirits that haunt caverns, forests, fountains, and cliffs as ever their ancestors were.

The Madonna of Tenos is, however, the Queen of queens, and numerous as are the pilgrim spots in Greece 
none can rival Tenos. The whole of the recognised Greek world is here annually represented, from the Crimea to Crete, from Corfu to the highlands of Asia Minor, where some of the purest Ionian blood still flows; and those who contend for the Slavonic origin of the modern Hellenes would do well to spend the feast week at Tenos, where they would satisfy themselves, beyond a doubt, that the Greek who goes to the island of Tenos to worship to-day is a lineal descendant of the Greek who went to the neighbouring island of Delos to worship two thousand years ago.

Whoever is distorted, withered, blind, or halt-whomsoever human art has failed to heal-all these can go to Tenos; and if the list of miracles every year is scoffed at by the sceptical, and said to be printed beforehand by the priests, yet the poor Greeks from the islands or mountains do not know this, and set off, with their hearts full of hope, their mattresses wrapped up in their carpets on their backs, and their families by their side, for a trip to Tenos.

This is only the general aspect of the pilgrimage; politically and socially the effect is wider. The birth of the panegyris at Tenos was coincident with the regeneration of Greece, and in the working of Greek politics for the last sixty years the annual excursion to Tenos has formed an important factor. Dissatisfied Cretans, oppressed Greeks from Asia Minor here meet the free sons of new Hellas on free Hellenic soil, and in this island yearly are sown seeds of revolt against Turkish rule, which the pilgrims take home and spread broadcast on fertile ground.

In the small town of St. Nicholas, at Tenos, the numerous cafés intended for the entertainment of these guests are adorned with wall paintings illustrating 
struggles in the war of independence, the seizing of Drakos, or the death of Markos Botzares. Then the musicians, with suitable national rhapsodies, such as ' $O$ my beloved sharp sword,' \&c., work upon the Greeks from the Turkish dominions in a wonderful manner.

We cannot too much admire the forethought of those who first organised this gathering of Greeks to an island in the centre of the Ægean Sea; they wisely did not choose I)elos, the centre of the encircling Cyclades--it would have been too apparent an adaptation of the pagan scheme-but Tenos is only a few miles distant; hence the geographical value of the position is but slightly altered, and the idea of a religious centre in the Cyclades is still carried on.

In 'I 822, the first year of the Greek revolution, a nun of Tenos dreamed a dream-the story of this dream is simple and oft told-and it resulted in the production of a picture of the Madonna, an $\varepsilon i \kappa i \omega \nu$ of miraculous powers, dug up at the spot indicated by the dream. In olden days it would have been the discovery of sacred books dexterously buried by the priests; in Western Europe it would have been some rumoured appearance of the Virgin to an ignorant peasant; in each case the result is the same. A report of miracles wrought brings countless pilgrims and money without end, a temple is erected, and at the yearly pilgrimage strange faces and strange costumes meet for once under the common name of Hellenes.

It was a cleverly conceived plan, the establishment of a miracle-working Madonna in the centre of Hellas; and insinuating rumours were spread at the same time, stating that the picture was found on the same day that the banner of the cross was unfurled for Greek independence, and at the time the war was raging the newly 
found sikì $\nu$ was placed in a golden frame, a thank-offering for miracles worked.

The Greek nation of to-day owes a debt of gratitude to religion which will probably never be repaid, judging from the state of religious feeling existing now in modern Athens ; yet throughout the dark ages of slavery the priests alone by their exertions kept the language, creed, and distinct nationality from becoming absorbed in the general break-up of the Greek nation. At the first echo of revolt the priests were the first to unsheathe the sword and head the rebellion. This fact the Turks recognised when they hanged the patriach of Constantinople at the outbreak of the revolution. The priests worked hard for the notion of Panhellenism, and with this view they chose Tenos as the centre of their work. Every priest throughout the Greek-speaking world tells his flock of the virtues of the shrine of Tenos, and those that go bring back to their remote villages tales of life and freedom.

The policy of the Greck Church has been to work, as nearly as possible, new theories on the old basis; this they did when Christianity was supplanting paganism. The Virgin took the attributes of most of the deities. She was ably assisted by her army of saints; the prophet Elias was no other than Phœbus Apollo (Helios); the archangels could hardly be distinguished from the Dioscouri, Hercules, \&c. ; whilst St. Nicholas was the sailors' god, the modern Poseidon.

Here at Tenos, Poseidon was worshipped in olden times as a physician. Silesias the Athenian set up a statue to him, and another to Amphitrite, each nine piques ${ }^{1}$ high ; and on the ruins of the old town of Tenos, sacred to Poscidon, the modern town of St. Nicholas is built ; and

Peche $=$ two feet. 
now instead of the temple to Poseidon stands the great white temple dedicated to the healing Madonna, to whose shrine our pilgrimage takes place.

Perhaps the scene on board the old ship 'Theoria,' which annually went to Delos full of pilgrims from Athens, the ship which tradition said had brought Theseus from Crete, was not so very unlike the scene on board the steamer 'Peneios,' which took me from the Piræus to Tenos. There were I,200 pilgrims on board, all in their holiday attire-women with their sack-like coats, gaudy petticoats, and coloured frontlets, that is to say, with the Athenian plait and the knotted ragged kerchief on their heads ; men with their fustanella of snowy white; each and all with their beds and their carpets, which they spread for their families on deck, and prepared for an al fresco night on board. Sardines in a box are not more tightly compressed than was the cargo of human

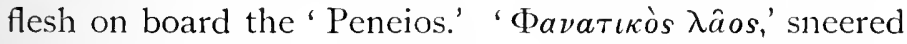
the captain as we looked down upon them from the bridge.

Music was played by performers on every species

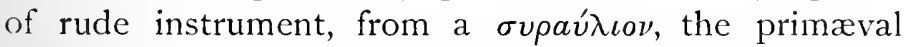
panpipe, to a barrel organ with its dancing marionettes. The raki drinkers were noisy now, laughing, shouting, blaspheming ; women were chatting, children playing: but before long we rounded Cape Sunium, and no more merry-making was heard; a death-like silence for a while pervaded the ship, and then groan succeeded groan in quick succession. Poseidon, the physician, was intent on a desperate cure!

' ' $/ \omega \eta$ ' $\mu o v$ !' groaned a woman close to me after each parnxysm had past. If I felt inclined to retort $\sigma a \dot{s}$

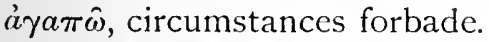

'Honey and milk!' groaned another pilgrimess. She 
had evidently come from the mountains, where they still mutter these words, to exorcise the demons of the air-a remnant, doubtless, of ancient times, when they used to offer honey and milk to appease the nymphs who raised the storm.

Daylight on our arrival at Tenos attested to the fearful ravages of the night. Our steamer was by no means the first to arrive, though the great day of the feast was yet two days off; and the horizon was dotted all over with steamers, caïques, and craft of various kinds, all bound for Tenos and the little town of St. Nicholas. I luckily had a letter for Kúpios Kapráons, one of the commissaries of the feast; a very necessary precaution, judging from the crowds which were turned away from every door. 'What are we to do?' asked eager mothers with sickly infants in their arms. 'May the God of the ravens help you !' was the encouraging reply. Seventeen slept on the floor of a small anteroom in the house in which we lodged, and thought themselves lucky.

According to our friend the commissary's computation, no less than 45,000 strangers visited the island from all parts of Hellas-Egyptian, Cypriote, Cretan Greeks, Greeks who had travelled for days and weeks from the inmost recesses of Asia Minor, all were assembled here to worship- and they have not only come to pray for their sick relatives and themselves, they have come to pray for the regeneration of their sick country and that their lot may be as the Cypriote's.

A Lesbiote argued with me one day, saying how much better it would have been for England to take Lesbos, commanding, as it does, the entrance to the Gulf of Smyrna and the approach to the Dardanelles; but unfortunately his arguments were wasted; Cyprus had 
been chosen. The question now was about Egypt Lesbos must wait.

Every pilgrim brought his present along with him in money or in kind, just as in former ages offerings and sacrifices were brought to the shrine of Delos. Thucydides, when he wrote of the crowds of women and children at Delos, of the musical and gymnastic contests, described the scene I saw. Mithridates, when he made $\Delta \hat{\eta} \lambda o s$ ä $\delta \eta \lambda o s$, little thought that the Greek nationality which he then sought to crush would burst forth again in all its vigour so close to the sacred birthplace of Apolto.

The narrow pier, the harbour, the windows, the balconies, the roofs of the houses encircling the harbour were darkened by an endless crowd. We could not turn when once drawn into the crush; scarcely could I move my hand as we were borne involuntarily through the little agora towards the broad street which led directly to the temple. The whole scene before us was like a dazzling dream-costumes, nationalities without end. The men for the most part wore baggy, loose trousers of blue

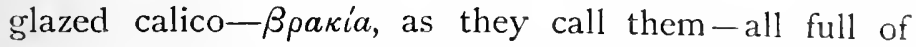
luggage dangling between their legs; a red sash kept these up ; a loose embroidered waistcoat covered their shirt, and a fez, placed sidewise, was on their heads. Greeks always adopt the costume of the country wherever theygo. There is hardly any trace of ancient dress; Turkish, Albanian, Russian costumes meet at Tenos every year with Greeks inside. Occasionally in the islands you

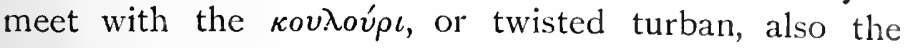
$\tau \rho o v i \lambda o s$, a sort of headgear like a Macedonian helmet, such as those we see on ancient vases; but every year these are getting rarer: the old women who wear them get laughed at by their grandchildren, who affect flowers 
and feathers, and European trash. The kovioúp $\iota$, indeed, is excessively pretty, being twisted coils of white around the head and a long streamer behind; it is supposed to represent a scrpent, and as such is emblematic of eternity.

This year the festival at Tenos fell in the Greck Lent. And the Lenten luxury of a pilgrim is also called a kounoúpı, being a cake made like rings and covered with sesame seeds. ${ }^{1}$ Eternity is likewise symbolised by these. The other Lenten luxuries of a devout Greck pilgrim are few. No meat, no eggs, on certain days no fish, and then the orthodox Church admits of no compromise, no purchase by money of absolution for indulgence. Herbs are the common food, and sweet innumerable, also cakes, called lachanopetta, composed of spinach mixed with onions and oil, fried, and then put in pastry. When Lent is over butter takes the place of oil.

Our ears were assailed by a perpetual din ; not only the shops, but even many of the private houses had been turned into wine shops, and had vegetable stall. in front of them, the owners having retired into a back room and given up their best apartments to the strangers. Down by the quay most of the commodities for sale were eatables, baskets of fish, bread, olives, caviare. Then there were cookshops redolent of savoury dishes, which were being fricd on charcoal fires; barbers' shops, the haunts of perpetual gossip ; and all the way up to the tcmple were small open air stalls, from behind which the cries were almost deafening, and containing pyramids of kounoúpl, almonds, and cans of Kalvas. Next came articles of apparel, men's hats, secondhand clothes, curious illustrations of the Russo-Turlish War, in which

1 Vide Naxos, p. 342. 
the Turks were invariably being severely punished, black and chestnut-coloured beads ( $\kappa \circ \mu \beta o \lambda o ́ \gamma \iota a)$, metal phylacteries, bone crosses, small tin phials for the holy oil, and bigger ones for the holy water. All was one prolonged din as we ascended the hill.

Then there were funny peep-shows; a mechanical hare dressed like a coachman, and moving his ears and head; and many pilgrims invested their ten lepta (one penny) to have their fortunes told by doves, which have been trained to put their beaks into a wooden box and to draw out coloured papers on which fortunes were printed, after the fashion of our crackers. I tarried some time near these winged Pythians, and one event amused me much: a middle-aged man and his wife consulted the oracle; they got a paper, but could not read it, so the proprieter of the doves volunteered to do so, and read as follows: "Your only fault is that you are slightly addicted to drink, and when drunk you tyrannise over your wife, who is better than you. To be happy you must abandon this vice.' The bystanders laughed and the old man blushed and led his wife on. Perhaps the Pythian oracle had spoken true.

Further on a blind beggar was sitting and singing in a dull, melancholy dirge, and shaking his box for alms, like Homer did, I dare say. This long street is a perfect medley of chaplets, knives, games, crosses, sweets, fresh fruits, linen, holy pictures, ornaments, cooking utensilseverything, in fact, to supply the appetite, religious and carnal, of the pilgrims, many of whom bivouac on the hillside to avoid the extortion of the town. Tenos is celebrated for its rogues on these occasions; fifty of them I saw shipped off at once to Syra jail, and amongst the modern Greek islanders 'a Teniote' is a by-word for laziness. In this feast week money 
for the rest of the year must be made: they cook for their guests, they lay open their houses to them, and they extort money, just as the inhabitants of ancient Delos used to do hundreds of years ago. A proverb is well known amongst the pilgrim-goers, which runs as follows :-

Who goes to the feast his purse must take, His money must spend, and not calculate.

The church on the hillside looked beautifully clean and fresh, being built of white marble from the quarries at the north of the island. A handsome marble staircase led up to the entrance, into which several old columns are introduced, which were brought from one of the temples on Delos again to serve for a similar purpose. Beneath the church the vaults were teaming with pilgrims, for here is the $\varepsilon u ̈ \rho \varepsilon \sigma \iota s$, the holy of holies, where the miracle-working picture was found. Around the courtyard, which covers above an acre, were receptacles for the human beings here assembled. Under the dome of the entrance, and about the courtyard, the goods sold were all religious, and the stalls of the $\varepsilon i \kappa \omega \nu$-sellers were a perfect gallery of quaint pictures. The silversmiths here were driving a rattling trade, selling silver legs, arms, cyes, houses, hearts, steamers, cows, as tributes of thankfulness to be hung in the church by some pilgrim whose safety from disaster came under any of these heads. They sold their wares just like Demetrius the silversmith sold his to the worshippers at the temple of Diana at Ephesus. Through all this crowd the supplicants press with candles and offerings; some carry young babies, still unbaptized, that they may be expressly consecrated to the Madonna; and at the baptismal ceremony here whosoever first succeeds in snatcling the baby from the 
priest after its immersion becomes its godfather, and it is curious to see the struggle between two or three for this honour. Not unfrequently you see a mother weigh her baby in scales, putting enough candles into the other balance to outweigh the baby, which candles are given to the Madonna during the festival.

Close to the entrance is a small well which was presented by an Ottoman Turk to the Madonna, and on my expressing surprise at seeing this I was told that many Turks believe in the efficacy of her miracles, and come to be healed.

Friday was the great day of the feast, and on the eve of the event the 45,000 pilgrims were wrought up to the highest pitch of excitement; crowds flocked to the church, which it was scarcely possible to enter. Three commissaries sat at desks close to the door collecting the offerings of the faithful; my friend asked us to sit by his side for a time and watch the haul-jewellery, embroidery, silver ornaments, bread, cakes of beeswax, money of all nations-nothing seemed to come amiss. The money was consigned to coffers beneath the desks, and men were in attendance with baskets to carry off the bulkier articles; in return for their offerings each person received a candle, which he lighted, and during the burning of this he supposed himself more subject to receive benefit from the healing exhalations which they say rise from the vaults below by means of marble gratings.

Twenty thousand pounds, my friend told me, was considered below the average sum realised at one of these feasts, when all the cheating was done, for of course there is much of this, and the post of commissary is one keenly contested for. The priests grow rich, and so do the inhabitants of Tenos; yet after all they do a great 
deal of good with their 20,000 l ; orphanages and charities of various sorts are maintained out of the proceeds of the panegyris at Tenos.

The shrine of Tenos is reckoned especially beneficial to the eyes. Blind men, women, and children lie for hours with their eyes fixed on the gratings through which the healing vapour is supposed to ascend. Perhaps the priests, when they concocted this programme for the sufferers, had been reading that passage in Aristophanes which recommends a plaster of Tenos garlic for diseases of the eye; for Tenos is celebrated for the fineness of its garlic; and the exhalations from the crowded vaults were redolent with the odour of this herb.

It was a fine starry night, and the thousands of little oil lamps which decorated the church and its steeple rivalled the lights of the celestial hemisphere in their twinklings. Patience, assisted now and again by an ingenious push, enabled us to get inside and witness the weird sights in the church-men and women were there grovelling on their knees; cripples, blind and halt, were imploring the favour of the Madonna; further on, a woman, after standing ominously still for a while, as if contemplating the scene, was suddenly seized with religious frenzy. She shrieked, she threw her arms about, and was carried out in wild hysteria. This frenzy was most infectious, and presently the whole church was full of hideous yells and maddened suppliants who are supposed when in this state to be under the special influence of the Deity. There is something that carries one's mind back to antiquity in the way these crowds are lodged. In olden days no inns existed on Delos, and at the festivals places of shelter were found near and in the temple. Now in

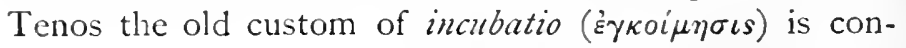


tinued, for when invalids aspire to a perfect cure they must sleep in the church for a night at least. In many of the temples of Æsculapius rooms were provided for the reception of invalids who wished to try this cure (Paus. ii. 27); it is the same to-day in Tenos.

$\mathrm{Up}$ in the gallery of the church crowds were collected, with their beds, their carpets, and their cooking utensils; for this partion of the church had been given up as a lodging house to those who were lucky enough to find room. Luckier still were those who could find a few inches of ground on which to lay their bed down in the vault beneath, for in the $\varepsilon \ddot{v} \rho \varepsilon \sigma \iota s$ they think they breathe sacred air. This vault or crypt is low, but little higher than a tall man's stature, and the denseness of the atmosphere was intensely stifling. Close to us as we entered were three blind men, holding on to one another, groaning and striking their breasts; behind them was a sinister form, which barked, as it were, not able to speak, and wriggled at my feet like a fish. Further on was a poor girl, in the last stage of consumption, leaning for support on her sister. A Greek islander has a horror of this disease; he believes that four Erinyes stand at each corner of the room in which the sufferer dies ready to pounce upon a survivor. An old man on all fours hindered our progress; and close to him a madman stood, still for the time being, but ominously so. A damsel stretched on the knee of her mother was relating, like Ophelia, in subdued and mysterious voice, some secret of her distraught brain, whilst her mother offered up a never-ceasing prayer to the all-healing Madonna for the recovery of her child's intellect.

It was piteous to look at a noble form leaning against the wall: she had a Greek type of countenance; her hair was black, and hung in rich tresses down her back; 
her eyes were almond-shaped, her nose straight; she seemed like a sister of the Caryatides, but, alas! like them, she was deaf. I advanced and found myself before a hole which led into an inner vault, and thence another opened out, but I could stand no more. Sick and faint, $I$ reached the open air after a struggle with the pilgrims, who were eagerly pushing in with their little tin phials they had bought outside to fill with water from the sacred stream. Others, too, were buying consecrated oil from the priests, which they poured into the eyes of their children, and which they were going to take home in little tins to their friends who could not come.

The priests were making piles of money down here by the sale of oil and water, by the administration of the holy services of their Church, by voluntary contributions, and so forth. They were worming their way amongst the sufferers, comforting the excited, exciting the weak-minded; and here this crowd was prepared to pass the night, as it had already passed several, with their mattresses wedged tightly one against the other, regardless of the poisonous vapours around them. Sevcral babies, I heard afterwards, were killed in this crush, and I wondered if the Madonna's healing power could avert the sickness which must arise from the pestilential stench.

The interior of the church is not very striking except for the crowd and the colouring. Within a gilded box,

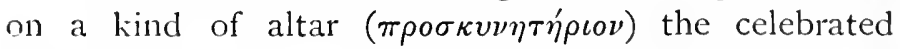
sik $\dot{\omega} \nu$ is enclosed. Its height is scarcely a foot, and its width only one and a half. The head of the Virgin and the angel Gabriel only are seen through holes, the rest is hidden with gold and precious stones.

Before this the pilgrims were bending in deep adora- 
tion and devoutly kissing the holes. They have done well to protect the picture itself from the ravages of the Greek kisses, by which they wear all their eikons away, reminding us of the statue of Hercules at Agrigentum, the mouth and chin of which were worn away by the kisses of the faithful, as Cicero tells us ('In Ver.' ii. 443). The lamps, too, which are hung all round the

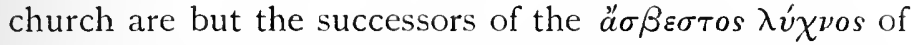
antiquity, which they still hang not only in the temples, but in the sacraria of their own private houses. Then the procession, too, had its equivalent in the ancient cult; except in name things are in very truth but little changed.

Close to the sacred picture stood a tin erection for the yellow candles, which were being constantly put up; in a quarter of an hour I counted more than one hundred, some as thick as a man's arm. Many leave handkerchiefs on this candlestick for hours, and then return to take them away, believing that, with the grease that has fallen on them, they have been imbued with virtue. Above the sacred picture from the roof was hanging a golden oil lamp with red lights, presented by an Athenian tobacconist. It is thought very efficacious to have bits of cotton dipped in this, and a man is employed from morning to night dipping these in and handing them to the pilgrims.

How curious is the mixture of faces-eager mothers with paralysed children; old men who have vowed to kiss this picture once before they died; robbers, too, who have escaped from justice, but not from the prickings of their own conscience!

A Greek crowd is imaginative, witty, full of fun ; one party of pilgrims was jesting with another, and the greatest good-nature prevailed. A suitable enigma was asked in my hearing amidst peals of laughter. Twelve oxen, four 
rakes, one hundred and fifty reapers, and the crop was only three bushels of corn? The answer proved it to be a sort of religious joke, treasured doubtless for the occasion. Twelve apostles, four evangelists, and one hundred and fifty Psalms teach us about a Trinity.

Another joke which I heard on the next day, which proved to be wet, I thought decidedly better: 'A church dome, sir, with only one pillar to support it ?' The allusion to my umbrella was obvious.

Down in the town quite another scene greeted us. Those pilgrims who had effected their cure or done their devotions were enjoying themselves vastly in the caf's. Dancing was the order of the night ; those curious weird dances of the Greek islands, for example, the ov'pros, a wavy line of five or six women, hand in hand, and led by a pocket handkerchief by one man, whose acrobatic executions were wonderful to behold. Then there was the rapid dance performed by rows of men with their arms round each other's shoulders, four steps backwards, four forwards, with pointed toe, first slowly, with the pace increased till I was almost dazzled by its rapidity.

A man, a noted dancer, performed for the benefit of the others who are tired: he turned somersaults in his white fustanella; he brandished knives in an alarming manner as he rushed to and fro; altogether he was a terrible performer, an Albanian Greek from the mainland mountains, they said.

Early in the morning of the great day; March 25, fresh steamers discharged crowds of sickly-looking individuals, for the night had been rough and a perfect hurricane was blowing.

Prior to the procession an interesting ceremony took place in the church, to which I gained admittance through the kindness of my friend. With doors closed 
and windows bulted, to exclude the common herd, the miraculous picture was taken out of its box to be washed, and when it came out of its retirement I strained my eyes to see it ; certainly it looked old and black enough for anything, but it was by no means a work of art, resembling an early German painting. Some roughly carved ornaments stuck on with wax adorned the frame, many of which fell off; those that did and those that were loose the officiating priest distributed as great prizes to the eager few who by favour or payment had gained admittance. A priest then wiped the picture with cotton wool, which material was eagerly scrambled for afterwards. Then the frame was washed with water three or four times, and the water which came off was collected in cans and again distributed to those who had brought phials with them on purpose to receive it.

Three rich blind Greeks next had a special service performed for their benefit; 'their last chance of recovery;' whispered my friend to me. How eager the poor things were! and how hard they prayed as the priest placed the picture on their heads, allowed them to kiss it, and applied it to their foreheads and their eyes! It was a melancholy sight, not easily forgotten.

Then the picture was restored to its shrine, locked up again, and the people who had been clamouring outside were re-admitted. At ten o'clock the mystic procession started on its tour round the town. Bombs ( $\mu a ́ \sigma \kappa o v \lambda a)$ were exploded as soon as the 'litany,' as it is called, appeared on the threshold of the church. All the bells of Tenos pealed, salutes from ships in the harbour responded, and, amidst drizzling rain and a piercing wind, the procession set off on its way.

The sea of men rolled beneath me, for I had securcd 
a seat for the occasion on a balcony; and as it went past it looked like a carpet sparkling with every colour-gold-embroidered tunics, snow-white fustanella, gorgeously embroidered skirts and vests from Asia sparkling with gold and silver coins, rich furs, and the more humble green and blue dresses of the islanders, mingled with a tinge of gaudy parasols and tall hats from the more civilised Athens. It was a sight to rivet and dazzle one.

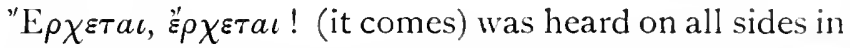
a dull murmur ; the procession was coming, and the crowd solemnly divided so as to make a passage for the priests. On the steps of the sanctuary the priests were marshalled, in rich vestments, carrying banners round the holy $\varepsilon i \kappa i \omega \nu$; then as a breath of wind disturbs a pool so did the advent of the procession disturb the almost breathless crowd below. Everyone made the sign of the cross and lowered his head in silence as it passed; and then when it was gone the murmur and the noise again increasedthe sacred ceremony was over.

Down by the harbour, in the agora, a prayer was held: the crowd shouted $\zeta \eta^{\prime} \omega$ (' Let her live!' i.e. the Madonna), and the picture was taken back to its home. Scarcely had the 'litany' returned to the church than the town was alive with a din of another sort ; namely, that made by the criers and steamer agents announcing their immediate departure. But first of all a large crowd was assembled round the peristyle of the church to get portions of sacred bread which was being doled out by servitors. Kyrios Kargades gave us a huge piece and a picture of the eikon, which had occupied our attention so much.

After midday the steamers sailed away, crowded with cager, struggling pilgrims - hungry, sleepy, worn-out, 
wretched, for the most part, after the week's dissipation ; but first of all the wide-winged report of miracles was let out amongst them. They did not see the happy cured ones; these were kept back wisely, no doubt under the excuse that the excitement of being exposed to the admiration and wonder of so great a crowd might be too much for their nerves; but printed accounts of miracles wrought were handed to each pilgrim as he went-no matter if it were the same list that was given to him the year before-he takes it home to read to his friends, who will then be eager to visit so marvellous a shrine in the following year.

The widespread honour paid to the Madonna of Tenos throughout Greece is wonderful. If a peasant girl is ill she vows what she likes best to the Queen of queens; on recovery she reflects that it is her hair. Accordingly, next year she takes or sends her long tresses as a present to the shrine, reminding one of what Pausanias saw at Titane, in Sicyonia, for he could not see plainly a statue of Hygeia for the quantity of hair and silk stuff which women had hung up as a sacrifice to it. A mother perhaps vows her sick daughter, when on the point of death, to the Madonna; the daughter recovers, and does not fall in with her mother's wishes, so the mother has to make a pilgrimage to Tenos to appease the Madonna's wrath, and does not escape without making a handsome present to the shrine. 


\section{The Island Itself.}

A year later, when I reached St. Nicholas one sunny afternoon in March by steamer from Mykonos, the vast difference in the appearance of the island was something indescribable. We skirted the green tufa rocks on the south side, and put into the open roadstead of St. Nicholas, with no other vessel in it but our own, one tiny boat sufficed to remove all that was to be deposited at Tenos this time. The green pier was all our own this time, and into the little agora chairs were brought for us to sit upon and wait for the eparch, to whom we had a letter. The stillness of death seemed to reign over the place that we had left in such a hurricane of excitement. But now we could study the spot and its inhabitants at our leisure, and notice things which in the bustle had escaped us.

The town looked especially white and clean, this whiteness being relieved only by occasional coloured carpets and rugs hung over the balconies, and yellow Venetian blinds, for the most part closed. They are a better class of house than you find in most islands, many having two storeys and slated roofs, whilst others are buried peacefully in olive gardens, with a few palms here and there. The churches, too, are white, and have curious three-storeyed minarets. The population just now looked sleepy and civilised ; indeed, as regards dress they were thoroughly European, being in constant communication with Syra, and at the festival time they have an opportunity of learning the fashions from Athenian Greeks. 
It was not our purpose to tarry long in the town on this visit, and at break of day mules were ready to take us into the interior, to explore those round hills above, for Tenos is an extensive island, being an eparchy to itself and having a population of 30,000 souls, of whom many are Roman Catholics ; for, next to Syra, Tenos has perhaps of all the islands in the archipelago been most in communication with the West. It is only 160 years since the last Proveditore of Venice left Tenos, and the last stronghold of Christendom in the archipelago definitely became Turkish.

That evening was the last but one of Carnival, an

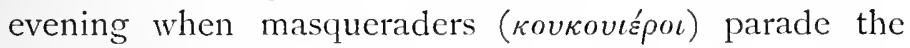
streets, pay hurried visits to their friends, and disturb the quiet of the evening with uncouth yells. This fell rather flat upon us, but served to remind us that it would be necessary to provide for the morrow; and a lamb was purchased to fortify us against the austerities of the Lenten fast.

We took a quiet stroll that evening up to the Church of the Evangelistria, and wandered through the corridors which in another three weeks would be peopled, as we saw them, with pilgrims. In one of these corridors we saw some remains of antiquit - -a statue of the Roman period. Antiquities in Tenos are rather meagre. Strabo, the traveller's vade meoum in these parts, tells us that Tenos had only one town, and that that was small; but by certain inscriptions we find that the island was divided into demes, the names of which bear no relation to the present nomenclature.

It is easy to see that the old town existed where now St. Nicholas stands, for just outside the town, on the hill slope, are traces of ancient walls, nearly six feet thick, by the side of which the present mule-track goes, until 
they end in a sort of acropolis or two watchtowers about forty feet apart, and of which walls twenty feet high are still left standing. In the town itself several recent discoveries have led to the identification of variolis buildings. There was a jetty, which is still visible, in the water, and where the main street, leading to the Evangelistria, turns out of the agora was once the gymnasium, the portico of which was found in a garden opposite; and probably seventeen small pillars standing four feet apart belonged to this building.

But there is no trace whatsoever of that renowned temple of Poseidon, where, as we learn from the Elgin Marbles, tablets were put up to the victors in the great singing contests held here. The temple was erected to Poseidon, so runs the legend told us by Pliny, because he cast the vipers (Tívıa है $\chi\llcorner\delta \nu a$ ) out of the island. Nor is there a trace of the temple of Dionysos mentioned by Strabo. All over the island, as elsewhere amongst the Cyclades, there are traces of watchtowers. One at Ando, near Cardiani, is in a good state of preservation, but inferior to those in Andros, Amorgos, and Keos. Archæologists have not gained much out of Tenos, though Ross tells us he was well pleased with a statue of Hermes he secured here.

At eight o'clock the following morning we were in the saddle, and the peculiar Teniote mule-cry ' $\partial$ ' $\xi \omega \nu \tau \dot{\varepsilon} s$ ' rang pleasantly in our ears as we climbed the hillsides, bare and bleak as they are, except for the large low figtrees which spread their branches far and wide. Immediately our eyes were caught by the great characteristic of Tenos, namely, the dovecotes. Every field has one, and curious objects they are, with bricks placed crisscross for holes, and quaint imitations of doves on the eaves. Below each is a room for the agricultural 
implements of the husbandmen who own the field, and the birds swarm around.

Is Tenos sacred to Venus? I thought, and then a strange parallel occurred to me. Surely Delos was celebrated for its doves in ancient days, and $\Delta \eta^{\prime} \lambda \iota s$ $\kappa o \lambda v \mu \beta \eta \dot{\delta} \eta \bar{s}$ was a well-known proverb in ancient Hellas. And here they are again, a speciality of the Panhellenic shrine. Some of these dovecotes are excessively pretty, when the clay soil which is placed on their roofs has streaked them with orange and yellow, and when the little chapel, with perhaps ancient pillars at its entrance, is joined to them; for every proprietor in Tenos possesses a chapel as well as a dovecote on his holding, and these are often side by side. Here the farmer has his warehouse $\left(a \pi \circ \theta \eta^{\prime} \kappa \eta\right)$ where he keeps his honey, his wine, his distillery for making raki, and other produce of his soil. In former years a great trade in doves went on in Tenos, but latterly very few more than are used for home consumption are kept, and many dovecotes are empty and crumbling into ruins. Wherever you go in Tenos these yellow crumbling ruins of a bygone industry form a pleasant object in the landscape, and I could not help wondering whether the Venetians got their taste for doves from their island dependency.

Crowning the loftiest summit of Tenos is the old Venetian town and fortress of Exóburgo covered with ruins around the rock which is bright with an orangecoloured lichen; and two ruined churches with curious towers, half Oriental, half Italian, recall memories of the Queen of the Adriatic. Everything is now delivered up to the jackals and the ravens; not a house has a roof on, the cellars are full of water and lovely maidenhair; but the streets can still be traced, and the importance of this Venetian colony is attested by its ruins. 
A superb riew on the summit amply repaid the climb. Every one of the Cyclades is spread out as though on a map at one's feet. With a clear sky even the Sporades may be seen; and scarcely any distance off lies Delos, the sacred speck of ancient worship; and to the north the snowy mountain peaks of Eubœa, hugging the mainland of Greece, fill up the horizon.

From this rock of Exóburgo it is interesting to look back on the mediaval fortunes of this island. In 1678 , when Spon and Wheeler visited it, there were only three or four houses down by the quay amongst the ruins of the old town where St. Nicholas now stands, and on this rock of Exóburgo the inhabitants of the whole island could take refuge in case of danger. Even the terrible Barbarossa, who carried devastation far and wide in the Cyclades, could not take this fortress, and when it was surrendered to the Turks in I 7 I 4 it was only owing to the pusillanimity of the then Venetian governor. Ross when he came in 1835 found two convents still inhabited up here, but now it is nothing but a deserted eyrie, like all its comrades in the Egean Sea.

Tenos, owing to this fortress, has always been a strong place; it offered a long resistance to the Venetians in the first instance, but eventually became a fief of the Ghisi family, until it was regularly governed by a Proveditore from Venice. Barbarossa besieged it in vain, and in 1570 a renegade Hungarian, Piali Pasha, made a descent on the island, spent ten days in ravaging it, but failed to take it, owing to Exóburgo ; three years later a Venetian governor, Proveditore Moro, repulsed the Turks again, so they gave up the attempt as hopeless. Tournefort in $\mathrm{I} 700$ found it in a state of great dilapidation : Fourteen badly dressed soldiers formed the garrison, scven of whom are French deserters. The Proveditore's 
post does not bring him in two thousand crowns, and therefore at Venice they look upon it as a place of mortification.'

No wonder fourteen years later we learn that Proveditore Balbi, not caring about his post, in spite of the supplications of the Roman Catholic families, who came in a body to implore him to stay, delivered it up to the Turks, and left it with full military honours. On reaching Venice Balbi was put in prison for life, but the deed was done, and the last stronghold of Christendom was lost to Venice, and two hundred Roman Catholic families were transported to the shores of Africa.

Exóburgo must have been inaccessible; indeed, it was all we could do, scrambling amongst ruins of houses and walls, to get down. It must have been a wretchedly cold spot, too, and I do not wonder at Proveditore Balbi being desirous to quit it. Luckily for us it was a fine, warm day, but for most of the time we had it in sight it was enveloped in a misty cloud, and when the north wind blows it must be simply intolerable.

Another striking characteristic of Tenos are the cow-

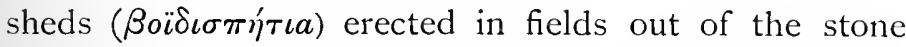
peculiar to Tenos and Andros, being large slabs which they easily break off out of the quarries. The result is that these cowsheds immediately strike the traveller as ancient Hellenic remains of the Pelasgic period, for in these cowsheds you might almost picture yourself in the gallery of Tiryns. I must confess to feeling doubtful about the first I saw, but when they were frequently repeated-and, moreover, I saw terraces for holding up earth, made of the same stone, and the ceilings of churches and houses, too, where in other islands they usc canes-the truth became obvious.

Tenos is very Roman Catholic still. At the time of 
Tournefort we learn that in processions Latin ecclesiastics actually took precedence of Greek, and in every Greek church was an altar reserved exclusively for the Latins.

On leaving Exóburgo we wended our way northwards through villages, bearing evidence of the Latin rule, entered by narrow gateways and containing narrow streets, with houses overhanging the footways; so that mules have to be unloaded at one end of the village. and the baggage carried through and put on again at the other end. Over the doors were lots of escutcheons of the Latin families, and at the village of Loutrà, so called from some baths which were there, we found several objects of interest; principal amongst them perhaps was the nunnery, presided over by an English lady, Miss Leeves, who has established herself in this remote corner of the earth. She once lived in Eubœa with her brother and his wife, but in $1856 \mathrm{Mr}$. and Mrs. Leeves and their child were murdered, and the sister removed to Tenos; and here in this quiet valley Miss Leeves has assembled thirty-three nuns, and fifty-five young Greek ladies are cducated under her roof.

Again Loutrà deserves a visit from an architectural point of view. The streets are narrow and quaint, and over the door of each house there is a curiously carved fanlight, semicircular and in marble; in different compartments of these are represented doves, horses, ships, palm trees, according to the taste or occupation of the owner. Now and again, too, you can see the escutcheon of a Venetian family which once occupied the house, whilst on the doorstep may be sitting now a Greek mother spinning away as she sings her vavápı $\sigma \mu a$, or lullaby, to her child, which she rocks with one foot in its cradle, improvised out of a lincading trough.

Loutrà is a very picturesque spot indeed, worthy of 
being visited by an artist. Below lies the only fertile strip of flat country in Tenos, for from the sea the island looks like a huge ball rising out of the waves. Instances of the religious tendency of the inhabitants met us at every turn. We never passed a well without seeing in its vaulted roof a frescoed picture of the Madonna or a marble relief of some saint, wreathed now, through neglect, with maidenhair, but none the less pretty for that. That evening we returned late to St. Nicholas, and actually passed the night at an inn ; it was delightful both to mind and body once more 'to take mine ease at mine inn ' after months of travel amongst hospitable, but occasionally rather boring, families, whose idea of hospitality was never to leave us alone, for fear we should be dull.

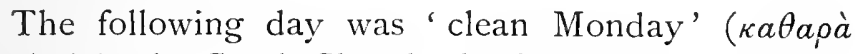

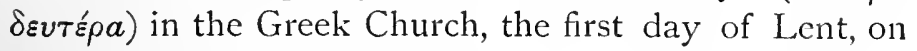
which the pious eat only clean food, and do not cook, so as not to have to dirty their saucepans. It is curious that custom has converted this day into one of the most festive of carnival feasts, for they dance, they drink, and otherwise amuse themselves; in fact, most of the men make a sort of Bacchic orgy of the day, cleaning out their internals with wine, so as to be prepared for the Lenten fast ; only they scrupulously abstain from flesh or fish.

Our programme for this day was first to visit a famous nunnery on the slopes of the mountain called

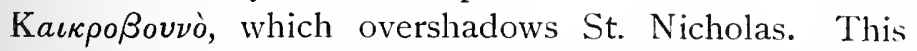
is the only extensive nunnery left in the Cyclades; the others are either closed or on the point of being so at the expiration of a few aged lives. But this nunnery owes its existence to its connection with the Church of Evangelistria, and is supported out of the pilgrims' 
pence. We rode along the dry bed of a torrent for some time bcfore beginning our ascent ; from a distance, and even when you are close to it, the nunnery looks like a considerable-sized fortified village perched on the mountain side; it has a wall all round it, and a gateway, just outside which is an inn for friends who come to visit the inmates. There are I IO nuns in all, and each nun has her separate little house; the church rises in the midst, consequently they have streets, or rather alleys radiating from this to where the nuns dwell, in which streets pigs, poultry, and filth abound, as in any other Greek community.

We entered the gateway under the image of our Lady of the Assumption, who presides over the place, and wore looked upon with wondering eyes by some nuns, whose infirmities would not admit of their attending the service which was going on just then, so they were sitting and basking in the sunshine instead. These Greek nuns do not look at all like their Western sisters : they tie a black handkerchief under their chin to the top of their heads, like a bib, and another over their heads; on ordinary occasions they wear a black gown and shawl, but in church they have cassock-like coats, after the fashion of the priests.

We asked for the lady superior ( $\eta$ yov $\mu \varepsilon^{\prime} \nu \eta$ ), but were told that she was in church, and that the 'hours' were going on, but if we liked we could go and join the worshippers. The sight was curious as we entered the church, thickly tenanted with nuns, young and old, withered and pretty, mumbling, chanting, and bowing. It was to us a weary 'hour,' standing in a stall, whilst the nuns went through their scrvice, which consists in reading the Psalter with a 'Gloria Patri.' Then they have the metanie, that is to say, bowing and kissing the ground three times after every 
fourth Psalm, and four times at the end of every tenth Psalm. The proper number of these metanice in twentyfour hours is 300 , I was told, but they are not obligatory ; it was certainly wonderful to see how active some of the decrepid old nuns were in performing their metania, and their perpetual prostrations must have an excellent effect on limbs that otherwise would be stiffened with years of inactivity.

Then how rapidly the officiating nun said her Kyrie Eleisons! which words have to be repeated a certain number of times at every service. On a day like "clean Monday' everybody is supposed to attend all the 'hours.' In former days, before the Eastern Church got slovenly, there used to be nine 'hours,' but now they are done by 'aggregation,' that is to say, into Matins can be run Lauds and Primes; into the Liturgy can be run Tierces and Sexts; and into Vespers, Nones and Complines. Through the services the nuns wade all by themselves, chanting and singing everything; only a special priest is kept to perform the incensing and the mysteries behind the screen. The church is covered with wall paintings. How terrified these poor women must be if they believe all the horrors depicted on the walls of their church by the conventional art of the Byzantine School!

After the service we were guided by a troop of nuns to the guest chamber. The lady superior, Paîsia by name, received us cordially in their plain room, furnished with the usual divan, sacred pictures, and a curious clock. Several sisters, with hypocritical faces, sat around us, talking for a long time about their 'lovely, unworldly life,' and then proceeded to tell us how poor they were, and produced home-made objects for sale-netted silk mittens, handkerchiefs, \&c. some of which we had to buy. Their poverty is evident, for many of them have not 
a penny of their own, and are dependent solely on the eight or ten francs largess given monthly by the Church of Evangelistria for clothing and food.

Païsia told us much about the working of her nunnery : how every five years a superior is chosen by the votes of all the nuns; she is assisted in her duties by a council of four, chosen in the same manner, one out of each of the four degrees, namely, novices, hooded nuns, crossbearers, and those of the highest order $\left(\mu \varepsilon \gamma a \lambda \circ \sigma \chi \chi^{\prime} \mu \circ \iota\right)$. She told us, too, how many of her children, as she called them, had really never seen anything of the outer world, and how sweet to them from the cradle, when deserted by parents and friends, had become the austerity of their secluded life. Now that Lent has begun, the nuns who are strong enough eat absolutely nothing for the first three days, drinking only a little water. After that, rice boiled in water is to be their daily food except on Saturdays, when they may put a little oil in. This is their Lenten fare; when fasting time is over they sometimes eat fish and drink a little wine, but never does meat pollute their mouths. It is almost impossible to believe in the atomic diet on which a Greek can subsist until you have been days with a muleteer, whose only food is olives and a crust of bread; and yet he never gets tired.

Paîsia, luckily for us, was not so strict a disciplinarian as some we met, and we were allowed to eat some of our lamb that we had brought with us; nay, even she went so far as to supply us with figs and wine out of their own storeroom, though it was the first day of Lent. After our meal was over a rather pretty sister was told off to conduct us round the place: we wandered in to the houses, chatted with the nuns, saw their handiwork, and made some more purchases. Then our friend took us to the cemetery. What a horrible place that was! just a small 
chapel surrounded by a few tombs, marked by nothing but sticks, with no other epitaph on than a number. The chapel was bare and unadorned inside, except for a terrifying wall painting representing the archangel Gabriel, sword in hand, as if ready to annihilate the beholder; and then our guide opened a door to the left, out of which a dank, fetid smell issued.

' Come in and see the charnel-house ( $\chi \omega \nu \varepsilon v \tau i \rho \rho ı \nu), '$ said she cheerily. As we entered by the dim light we saw rows of female skulls, which seemed to glare at us with indignation for disturbing their repose. To our left was hanging what looked in the uncertain light to be spiders' webs covered with dust. Our guide said:-

'Whenever a novice comes her hair is cut off and hung up here. Let me see,' she said, pausing and shaking a grimy tangled mass, "this is mine, number 1003 : when I die I shall be buried for three years, dug up again, my skull put up on that shelf, my bones packed in yonder cupboard, and I shall be entered in the deadbook as number I003.'

We were not sorry to bid adieu to this strange monastic village, and to enter the world again. Our path led us through two villages on the hillside; at one of these, Arnades, celebrated for its lambs, and called therefrom, I bought a pretty little ancient lamp, which a cottager had in use in his house ; further on I picked up on the roadside one of those basalt stones, with grooves in it, used in ancient times for polishing marble; so Tenos, even in its hill country, is not without evidences of antiquity.

These hill-set villages of Tenos are particularly dark and gloomy. You can go from house to house by the roofs without troubling the dingy streets; they have steps by which you can ascend from one roof to the 
other; and the inhabitants seem chiefly to live on their roofs, abandoning the filth below to traffic and pigs.

Close to Arnades are two villages, called $\delta v^{\prime} \omega \chi^{\omega \rho} i \grave{a}$, or the two places, being quite close together; and here we came in for some of the gaiety incident on the first day of Lent; the sound of music and revelry filled the valley, and from afar off we descried the cause. All the villagers had turned out on the roofs, and on this flat surface were dancing away vigorously. As no other flat space occurs in or near the village they are driven to make a ballroom of their roof. In Tenos they mend their mud roofs with brick dust ground in a mortar and made into a paste; this strengthens them and makes them very pliable.

The dancers had put a flag up, and spread a white cloth on the roof for their repast, which consisted of olives, onions, bread, and wine in a large amphora. They were dancing to the tune of a sabounc, and what to us was a new instrument, called a monosampilos, and consisting of a small gourd fixed at one end of two reeds and a cow's horn at the other. The music produced by this instrument was quaint and shrill, like that of a bagpipe or the sabouna, which in this case was made of the skin of a goat, with all the hair left on, so that when the musician put it down it looked quite alive, and palpitated visibly.

For a long time they continued to dance the inevitable syrtos, until they had had lusty and long pulls at their ampliora of wine-and the wine of Tenos is by no means light, for here they made, and make still, the farfamed Malvasianor, or, as we know it better, Malmsey wine. And in ancient times, on the reverse of a Teniote coin, we see a bunch of grapes, with Poseidon on the obierse, pointing to the same reputation. Then they 
started a dance called by them 'the carnival dance'

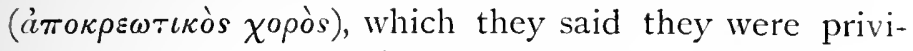
leged to dance on the first day of Lent. It was a very amusing one : eight men took part in it with arms crossed, and moved slowly in a semicircle, with a sort of bounding step, resembling a mazurka. Occasionally the leader took a long stride, by way of adding point to the dance, but they never indulged in the acrobatic features of the syrtos, and never went so very fast ; the singing as they danced was the chief feature and fascination of this carnival dance, and their voices, as they moved round and round, to the shrill accompanying music, had a remarkable effect. The words of their song, which I took down afterwards, formed a sort of rhyming alphabetical love song. It is needless to say that A stood for love $(\dot{a} \gamma a \dot{a} \pi \eta)$. $\Theta$ spoke of the death (Aávaros) which would be courted if that $\mathrm{M}$ or apple ( $\mu \hat{\eta} \lambda o s)$ of Paradise was obdurate. P stood for póoov, the rose, like which she smelt. $\Psi$ was the lucky flea ( $\psi v$ ú $\lambda$ os) which could crawl over her adorable frame, and so on, till $\Omega$ closed the song and the dance with great emphasis, imploring for a favourable answer to the suit.

It was now time for us to bid farewell, as the shades of evening were drawing on, and we were some miles from St. Nicholas. We passed other revellers on our road, but stopped to look at none, save a party of small children who had got a flag, a small bottle of wine, olives and bread, and were imitating the revelry of their elders on a threshing floor by the roadside.

Next morning early we left St. Nicholas, doubtless for ever, and wound our way on muleback along the western coast of Tenos on our way to the northernmost demarchy, Panormos by name. Well for us that the Teniote mules were trustworthy, for we had to pass 
along one of the worst paths we had yet seen in the Cyclades-more like a series of little precipices than a road. 'Our mules are better than those of any other island,' remarked our muleteer with the usual insular conceit. And to prove it he told me a story of how an old blind man came this way regularly on his mule on his way to St. Nicholas; and not only did he implicitly trust to his mule down these precipitous paths, but he left it to the mule to choose the house where he should stay when he got to St. Nicholas. 'This mule is very' fond of change,' he added, 'consequently no one knows when the mule may not stop at their door, and they may' have the old blind man as their guest.'

Near the little harbour of Stavros we passed by what our guide pointed out to us as the site of the ruins of the temple of Poseidon, but I could see no grounds for such an assertion on his part-only a few foundations of walls and the traces of an old watchtower.

$\mathrm{Up}$ in the mountains all was mist to-day; we rode past a hamlet composed of mandras of nothing but Teniote slabs, which looked quite archaic through the mist that encircled them, and midday found us at Kardianè, a pretty place climbing up the mountain side, and overhanging the sea, like a Riviera village, with a tall white church tower and pretty balconies to each house. We lunched in one of these festooned with vines, and having large earthenware amphore picturesquely stuck about at haphazard; also lovely gourds which were drying a rich orange colour, plants of geranium in full bloom; and through olive trees we pecped down at the sea beneath us as we consumed our meal.

Nothing can be more trying than the sudden changes of temperature in these islands. At Kardianè we basked in the sunshine; half an hour later, on ascending the 
mountain, we were cut to pieces by a biting north wind ; and when we reached a cleft in the mountain full of windmills, before reaching which I knew what our fate would be, we encountered one of the most biting blasts I ever felt.

Tenos is especially noted for its winds. A legend here still tells you that the winds live in caves at the north of the island; they tell you, too, that Michael, the archangel, once slew here two refractory north winds, and placed pillars on their tombs, one of which rocks when the north wind blows. What a curious survival this is of the legend of Hercules, who slew Zetes and Kalais, sons of Boreas, near this island with arrows, over whose tombs two sepulchral stelæ rocked when Boreas blew!

There are many legends about the winds, which have survived the lapse of ages. K $v p$ Bopéas, Mr. Northwind, as they call him, is always a dreaded visitor. He lives, they say, 'somewhere up there,' pointing vaguely towards Thrace, in a palace of ice and snow ; but Mr. Southwind chose to blow one day and melted it all, so that nothing was left save the tears, which flowed riverwards. On the feast day at Tenos they say that the wind which blows has conquered the other winds and will prevail for the rest of the year; when we were there it was one of the most biting north winds I ever experienced, and it was most probable that $\mathrm{K}$ ì Bopéas would prevail for the rest of the year, for in these islands the north wind blows incessantly in summer, making them cool and refreshing even in July and August.

We reached Hysternia after an hour's ride-a dark, gloomy place, with brown houses and brown pig-dirtied streets, with nothing of interest save the elegant fanlights over the doors and windows, differing considerably from 
those of Loutrà, as they represented stars, the sun, \&c. ; so after a short rest we pushed on to Pyrgos, which is the chief village of this northern deme, where the demarch lives, to whom we had a letter. It is a very flourishing place, and the centre of the marble district, from whence have come all those marble window-tops we had admired elsewhere; and in the centre of the village they have erected an claborate marble well, and a marble cage in which the washerwomen work, in the middle of the agora. The villagers were seated under a wide-spreading plane-tree as we approached, from amongst whom the demarch emerged to give us greeting.

Pyrgos is one of the prettiest villages of the islands, being quite Alpine in character, situated, as it is, in a hollow basin surrounded by lofty mountains. A river leaping from rock to rock runs down the central street, and is spanned by pretty wooden bridges. From the demarch's house, which is higher than its neighbour, we had a lovely view over almond trees, now in blossom, cypresses, mingled with the yellow and white houses, with the rugged peaks of the Mount Prophet Elias of Tenos as a background. Most of these houses have productive gardens. The demarch took us to his, where he complained that his neighbours' hens were wont to trespass; and he laughingly told me that here at Pyrgos the women had a charm for keeping their hens from trespassing, which he intended to make his neighbours use : it is as follows:-

"When you see the first stars of an evening, sing this song, "O star, first star, I have three basins - one of silver, one of gold, and one of lead. I want neither the silver one nor the gold, but spare me the lead, that I may prevent my hens from eating the crops." If you sing this song with implicit faith your hens will never trespass.' 
Curious and meaningless as these incantations sound, nevertheless the women still believe in them. Later on at dinner we opened the subject again, and the demarch's daughter, who stood in the background ready to attend to our wants, was constantly referred to as an authority on this subject. She told us a most efficacious one against the bite of the very poisonous serpents which, in spite of what Poseidon may once have done towards ridding the island from them, are still very numerous, and account for the name of Ophiousa, by which Tenos was once known, and the name of 'Teniote evils' which was commonly applied to vipers.

'Spit first on your wound and say, "Elle, Elle agra!" three times, spitting before each time, and then say, "Pede" without spitting, repeating these magic words nine times to effect a perfect cure.'

'What do those words mean ?' I enquired of our host.

'Nothing,' was his reply ; 'we generally believe them to be Arabic ; all I know is that they are most efficacious,' and then he paused as if another idea had struck him which might interest us and continued: 'Here at Pyrgos we never begin any new work on a Tuesday, for it was on that day that Constantinople fell into the hands of the Turks. Yet at Pyrgos we are reckoned more industrious than elsewhere in Tenos; we employ many hands in our marble quarries, we ship caïque-loads of marble from the port of Panormos, and no island has such good marble as ours.' The old demarch spoke with great contentment and pride of his home, and we could not help wondering what the men of Paros would say if they heard this assertion about the value of the Teniote marble.

They are very primitive, these men of Pyrgos. In spite of their good opinion of themselves, even our host 
the demarch had but sorry fare and a still sorrier bedroom to offer us, with an ill shut door out into the open air and a blindless window into the common sitting-room. There were heaps of eikons, old chests, and censers, but not a luxury in this den.

Next morning we left Pyrgos early and returned to Hysternia by the temple of Æolus, where the windmills were, and the customary doubt occurred as to whether the steamer which was to take us to Andros would come or not. After an hour's delay we saw her steam out of the harbour of Syra, which gave us ample time to collect our traps and scramble down the hill to the port, or rather little open roadstead, before she arrived.

We crossed in safety the narrow strait between Tenos and Andros, justly feared now as in ancient days for its treacherous waves, being so near that dreaded and mythical spot Isiknia, where, mariners tell you, is the very home of the winds; after which we had time to enjoy an excellent meal provided for us by the steward of the 'Elpis,' and to turn over a new page in our diary. 


\section{CHAPTER XIl.}

ANDROS,

\section{Eastern Andros.}

ANDROS is the second-largest of the Cyclades, and with Tenos forms a part of that chain which on the map looks as if it ought to form a part of Eubœa. The mountains are more lofty than those of Tenos, its valleys deeper and more fertile. It boasts of streams which do not dry up in summer time, and its ancient attribute of Hydroussa, or the watery isle, is well maintained to this day. As we coasted along the eastern side it did not look prepossessing, and we shivered when we saw the black mountains, still covered with patches of snow, though March was well on, which we should have to cross in going from place to place.

But on landing the gloom entirely disappeared, for the town is highly picturesque : old houses of all colours are built on a narrow rock which juts out into the sea, and on an island rock connected with this tongue of land by a fantastic bridge stands the mediæval castle, all now in ruins. Behind this town stretches inland one of the most fertile valleys in the world, and the slopes of the mountains are dotted with villages peeping out of cypress and lemon groves. Andros, in fact, is the best wooded of the Cyclades, and second only to Naxos in size and beauty. 
Our letter was to the eparch of Andros, a gentlemanly old man, of a Pariote family; but lodging with an eparch is not repaying on the whole; he is generally a stranger and knows nothing whatsoever about the island over which he rules. He inhabits a large house provided for him by Government and furnished with as few comforts as possible, for he is a bird of passage. Eparch Matzi was no exception to this rule, for his comparisons between Andros and his native Paros were not to the advantage of the former. To his wife Kyria Matzi we shall be for ever grateful, for immediately on our arrival she introduced us to the great Andriote luxury limonakki, tiny green lemons made into a jam, so deliciously soft, and so deliciously sweet, that we longed for a potful and some bread and butter. If you get a treat in the way of jam in Greece it is truly aggravating only to be able to take one teaspoonful, and to have to wash that down with raki and water.

Lemons are so plentiful in Andros that they can afford to make jam out of the little ones. The whole of the southern slope of Mount Petalos, which runs across Andros and divides it into north and south, is one vast lemon garden. Boxes of lemons wrapped in paper are despatched to Constantinople, Russia, and England, and wherever we went we were presented with lemons in painful and burdensome profusion. Of late years a withering disease has attacked this staple trade, and the wealthy lemon-growers of Andros are feeling greatly concerned thereat.

Until a few years ago Andros produced a large quantity of silk, and still a great number of mulberry trees are scattered over the plains and hills; and one is surprised to find many houses of the poorer classes in the town so large and commodious: it is because once upon a time they were constructed with a view to the 
manufacture of silk. Fifteen years ago disease attacked the worms, and numbers of fine mulberry trees were cut down and lemons planted in their stead; with the fruit of those that are left they make a disgusting potent

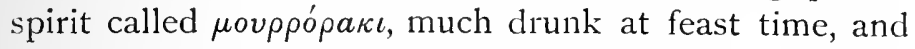
the cause of many a bloody brawl in Andros. In those days the Andriotes were very superstitious about their silkworms, and a woman who wished to secure a good crop of silk believed it a sure plan to appear stark naked on her flat roof at the early dawn of May morning. This curious custom is luckily not considered necessary for the success of the lemons, and hence it is abandoned, but it reminds one, oddly enough, of that lively picture drawn by Terence, in his 'Adriana,' of the women of Andros, which does not credit them with an abundant stock of morality.

With her mulberry trees useless, and her lemon trees blighted, Andros is not very flourishing just now, and that bane of insular Greece, namely, emigration, is going on in full swing; and, what is almost worse, many go to America for a few years to amass a little money, leaving their lands untilled and uncared for until their return. Andros properly managed might be a perfect paradise ; corn is good and abundant; it received a medal of the first order at the Paris Exhibition of 1867 ; almost anything they choose to grow here would prosper with proper management.

We took a stroll round the town soon after our arrival, and were pleased with all we saw. The old town on the tongue of rock is entered by a gateway, and the houses are pretty, having more woodwork about them than is common in these islands; red-tiled roofs are rather a relief after perpetual flat ones. Over many house doors may be seen a ship carved in marble, betokening the occupation of the inmate, just as over the church 
doors a marble figure of the patron saint is inserted. A narrow street leads down to the bridge, one lofty span now crumbling into ruins, which leads you to the island where the Venetian lords of Andros lived. It is built of a greenish stone, much eaten away by the action of the waves, which in a storm lash themselves to fury around it.

Andros became Venetian property as far back as I 204, when Marco Dandolo took it, and then the wellknown Zeno family had it for generations as a fief, the heiress of whom brought it as a dower to the Sommaripas. The Andriotes themselves turned out their last ruler of this family, and gave themselves voluntarily to the Turks. Some of the Sommaripas still live at Naxos.

Later on I walked out into the plain, and was struck with the fertility of the fields; those which are exposed to the north wind have cypresses planted around them to break the force of the 'king of the winds,' and they make tall hedges of bamboos, which sway before the tempests and protect the crops. Certainly Tournefort was right when he said that the traveller who leaves the town of Andros will enter upon one of the most beautiful plains in the world. Each garden has its large water-tank, which is worked by wheels for irrigation, and from the hillside to the south, up which we climbed, a coup d'ail of greater fertility would be hard to find ; but the hills themselves are barren and bleak, especially where the force of the north wind is felt, and miles of stone walls, curiously made, with great, big slabs at an interval of every two yards, built around with smaller stones, do not look picturesque.

Lent in all its earnest asperity was now in full swing ; we knew that in the interior no flesh could be obtained, so we purchased another fat lamb to take with us. Lent is indecd a fearful season of abstinence. Like the nuns of 
Tenos, we found many women performing the $\tau \rho i \mu \varepsilon \rho o{ }^{\prime}$, or three days' fast, on nothing but water, and for the first wcek the truly pious would not think of touching anything but vegetables and bread. If an animal falls ill during this long fast they kill it, and pickle it for the Easter feast; every egg that a hen lays during this period is hard-boiled, and put by till the fast is over: so, to guard against starvation, we took with us our lamb and a little caviare, which came in most opportunely. At all times and seasons the Andriotes are most abstemious, and seldom indulge in other flesh than that of pig, except at weddings and feasts. After the feast of St. Demetrius (October 26) the season of the pig slaughter ( $\chi$ oupo$\sigma \phi a ́ \gamma ı a)$ begins ; each householder kills one or two, part of which they salt, and part they cut up into little bits, and cover with pigs' fat in earthenware jars: this they keep for a whole year, and eat as occasion requires. They make sausages of it, and put it into omelets, and cook it with poached eggs; it is invariably green, and tastes rancid, but it is deemed a great luxury, one which at times we hardly dared to refuse.

A good road is in course of construction up the fertile valley along which we made our way at a rapid pace until we came to the village of Messarià, which has a church, of considerable architectural merit, dedicated to the archangel Michael, on a pillar of which we read that it was built in the reign of Manuel Komnenes in I 57. It is of pure Byzantine style, with a dome, and divided, as old churches of that date were, into narthex, middle temple, and holy place. The screen is of white and grey marble, and has on it several carvings, representing St. John's head in a charger and Constantine's two-headed eagle. It is a venerable structure, and points to Messaria as having been the second capital of Andros after the 
abandonment of the early Greek city, and before the modern town was commenced. It was favourably placed for defence high up in this fertile valley, and not until much later days, when the Venetian lords erected a fortress, could it have been possible to dwell by the sea where the capital now is.

Turning to the right we soon entered the paradise of Menites, with delicious streams rushing down the gorge from the mountain side, and bathing it in verdure ; luxuriant maidenhair fringed the water mills, and on banks of soft moss we actually found primroses growing in abundance, and we were glad enough of the shelter afforded by the houses hidden away amongst the trees to take refuge from the midday sun.

At Menites we were first introduced to the towers of Andros, a peculiarity of the island, which arose from a constitution which it appears alone to have possessed. Until quite recent years the Andriotes were divided into two classes, the archons and the tillers of the soil: the former generally traced their descent from Venetian families, and each of them built a square tower in the midst of his land, and was a person of authority. There was a curious custom amongst these archons, that the first son who married always inherited the tower and the estate, whilst the others entered monasteries, became schoolmasters, or sought employment in foreign parts: hence Andros is especially rich in monastic establishments, several of which are still in existence.

These square lofty towers form a curious feature in the landscape. Originally they were entered at an upper storey by a ladder, which drew up and secured those inside from invasion. To the lower storey there were no doors or windows, but it was entered by a trapdoor from above and served as the family storeroom. 
Round the top of the towers were overhanging niches, out of which the beseiged could pour boiling oil and shoot their assailants; but, thanks to the quiescence of modern times, the gloomy aspect of these towers is much ameliorated. Stone staircases have been fitted on outside, to serve as approaches instead of ladders; windows have been opened, and in most of them an air of comfort now reigns.

But the family pride of the archons is by no means extinct, though under a different régime their power is greatly modified. They are exceedingly strict about marriages, and if the son of an archon demeans himself by wishing to marry beneath him the paternal wrath is at once aroused: the young man's father will say that the girl has used magic to attract her lover, love philters and potions, such as they have plenty of in Andros, but which are discountenanced by the, Church as emanating from the devil. In the face of accusations such as these the young man can hardly continue his suit for shame. Many of these little artifices are attributed to the girls of Andros, such as sewing something on the sly into the coat of the object of their desire, or stealing his handkerchief and shuffling it in some mysterious way as they mutter incantations. These are harmless enough, but they know more intricate ones than these, which are brought into requisition if the simpler ones fail, and which are not very pleasing to recount.

Silly Andriote women think, too, that by treading on their husbands' foot during a certain portion of the marriage service they will command in the household. We were shown one day, as an instance of this, a young woman who had lately married and tried this method on ; and so enraged was her newly acquired husband that as soon as they returned from church he gave her a good 
beating, and now she looks as humble-minded a helpmate as any man could wish to have.

Menites has a church through which a sacred stream of water flows. 'This,' said Kyrios Kretes, who was acting as host, 'was the celebrated temple of Dionysos, where once a year the water flowed as wine in ancient times.' I privately begged leave to differ from him, first, because there is not a vestige of antiquity in this part of the island; and secondly, because a sceptical nature suggested that a miracle such as this must have been difficult to perform on a stream which runs straight down from the mountain side; if it had passed through a tank behind I could have understood it. No; we must look elsewhere for our temple of Dionysos. Every house at Menites was gay with flowers-geraniums, double stocks, and other sweet-smelling flowers-for without they are sweet-smelling or useful for something a Greek despises flowers. Inside, too, the houses were clean, and for the most part stocked with boxes for the lemon trade.

The household jams of Andros are really exquisite ; jams of lemon flower and roses, jams of citrons and quinces; and the honey cakes of Andros are things to dream of ; they are made of honey mixed with walnuts and served up on lemon-leaves. Such delicacies as these are commonly reserved for feast days, but we were guests in a foreign land, and the accommodating housewife was proud to show us her handiwork, even though it were the first week in Lent.

We left Menites, with regret, late in the afternoon, and made our way towards the great monastery of Panáchrantos, the richest in Andros, where we proposed to pass the night. This monastery is built on a fearful spot under the rocks of the mountain ridge, to the south 
of the vale of Andros, so that it faccs due north, and in the winter months gets no sun, and is exposed to every chilling blast. As seen from below, it is like a village with a wall all round it, of dull brown stone, and with a whitewashed church rising up in the midst. There were quantities of leafless mulberry trees around it, and a gushing strcam which was swollen by the melting snow from above. Inside, it was just like the nunnery of Tenos-intricate lanes and alleys full of pigs and fowls, leading into a sort of agora before the church, where in summer time the monks meet to chat; but now nothing could equal the chilliness of the spot. Evening had come on before we arrived ; huge mist clouds rolled down upon us from the mountains, and everything we touched about the place felt clammy and damp. We were conducted down endless lanes and passages to the room of the

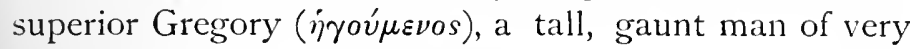
ascetic appearance, which inspired awe. Our comfort was not enhanced by the presence of a madman, who frequently told us that he was king of Andros, and that this was his favourite palace. Superior Gregory apologised for him by saying that there were no asylums in Andros, and that when a man is too dangerous to be at large he is taken by a monastery out of charity. Then again the lay brother, who acted as servant to the superior, had no chin-a most repulsive object to look upon. His duties are to wait on the superior, ring the bells, light the candles in the church, and say 'Kyrie eleison ' as fast as he can at the proper time; and to fulfil these offices the good monks always chose a man whose deformities would unfit him for shining in any other rank in life.

Though I have visited many monasteries in Greece this was the first time I had passed a night in one, and I must say my curiosity was blended with awe at the 
appearance of those around me. Superior Gregory looked very cross at us from time to time, and presently I heard that our servant had suggested that, as we were tired and hungry, we should like to cook a portion of our lamb for our evening meal. 'Unheard-of thing!' I heard him say. "Why, to cook flesh in our monastery during the first week in Lent is against the canons of the Church ;' and feeling that we had imposed our society on them we felt it only right to offer no remonstrances, though when dinner time came our hearts sank within us. Our bill of fare was as follows-First course, a soup of rice boiled in water, and tasting chiefly of the latter ingredient. Second course, a soup of lentils and onions, more substantial than the last, but horribly unsatisfying to hungry travellers. Superior Gregory then graciously permitted us to eat some of our own caviare, and even went the length of producing red caviare, such as the Greeks rejoice in, and kalvas, a Turkish sweetmeat made of sugar, flour, and sesame oil. Such was our meal, which we washed down with generous wine, and as the meal went on the stern Gregory thawed a little.

Our next fear was about sleeping arrangements, and here again our worst apprehensions were realised: we were to occupy a damp cell, no sheets on the bed, only coarse home-spun rugs, and these dripping with wet.

'Matins will be at four o'clock to-morrow morning,' said Gregory as he somewhat sarcastically wished us a good night.

'Must we be there?' asked I humbly; our tyrant considered a little, and then told us that we might remain in bed if we wished, being heterodox and travellers.

It was the first Friday in the great fast, so matins in the morning would last four hours. 'Should I go?' thought I; and when, at four o'clock, I was sleepless 
and heard the semandron sound, I decided that bed offered no charms and went.

The Greek semandra are curious inventions for making a noise. Each monastery has generally two, one of wood and one of metal; the former is a planed piece of timber, made often of maple wood, about three feet long and nine inches wide. This is hung up outside the church, and the ringer produces his noise by striking it with a wooden mallet. As a rule, the wooden one only: is sounded at dawn, but to-day, being a great Lenten service, the iron one was sounded: it is a semicircular hoop, which produces a noise not unlike a cracked gong. I have heard that these semandra date from the days when the Turks refused to allow the Christians to use bells. In the dead of night it was a curious noise, and as I issued forth into the chilly morning air and saw the monks, lanterns in hand, hurrying to church, I seemed to be wafted back into centuries long gone by ; the wind was howling and driving large snowflakes against our faces, and on this occasion I learnt the word $\varepsilon^{\prime} \rho \omega$ for p'i $\omega \omega$, 'I shiver,' a specimen of Andriote patois which I shall never forget.

'Amen, Amen, Adam!' were the words I caught as $I$ entered the church and took up my quarters in a stall $(\sigma \tau a \sigma i \delta i o \nu)$ which had no seat, only room for the elbows, and which are represented in some parts of Greece by crutches, on which the infirm support themselves during the lengthy services, for sitting is not allowed.

The church of the monastery of Panáchrantos is a beautiful one, and looked especially well with plenty of candles and oil lamps. The tempelon, or screen, had a sort of dado of rich Rhodian tiles let into the woodwork, and above were six large silver eikons of St. Michael, St. John the Baptist, \&c., with all the mysteries of their 
lives embossed in silver, which were set in richly carved wood, and along the top ran twelve little arched compartments for pictures of the twelve apostles. I had plenty of time for observing all these things as the service went on, and not until it was nearly half over was I conscious of great fatigue and numbness of limb. "How can these monks,' I thought, 'for ever be chanting their offices and their hours ?' a tedious liturgy followed by a still more tedious life of some saint or hermit, and endless monotone hymns, which jarred horribly on my ears. Then, again, everything is said and sung in an almost inaudible tone by the priests; you strain your ears, but fail to catch many consecutive words; for they wish to keep up the idea of mediation between God and man.

The most terrible things end at last, and at eight o'clock my matins at Panáchrantos were over. I had gone to them voluntarily, so could not ask for pity. I felt very sorry for myself nevertheless, and the chilling effects of Panáchrantos a few days later made themselves unpleasantly felt. I even felt relieved when I found that by no manner of means could we wash ourselves that morning; there is a time when cold water may be repugnant even to an Englishman.

By attending the service I think I went up greatly in the estimation of Gregory, for he was now quite eager to show us over his treasury and to provide us with what food he could before starting.

'Ah!' said he, 'you should come here at Easter or on our feast day, August 15, when we walk in procession round the walls of our monastery, with banners and the silver eikons. It is lovely here in summer-no heat and perpetual balmy breezes. A monk's life is always peaceful and happy.' 
Panáchrantos is a fairly old monastic establishment, though the date of its foundation is uncertain; we, at all events, know that it was old enough to be repaired in 1608 . It owes allegiance directly to the Patriarch of Constantinople, and not to the Bishop of Andros and Keos, and hence it is called a $\sigma \tau a v p o \pi i$ r honour it pays annually to the Patriarch an oke of wax.

The silver in their treasury is very fine: a silver arm and hand beautifully embossed has been made to accommodate a morsel of the bone of St. Marina's arm and finger. Quantities of jewelled crosses and filagree objects for relics; a silver mitre, to contain a portion of the skull of a saint ; lamps, \&c. : and all these things huddled together in terrible disorder in a room, the window of which had lately been blown in by the north wind, and which, being on the outer wall, would form an excellent opening for an athletic thief. The glory of Panáchrantos is fast departing: the library has been sold, or destroyed by the damp; most of the two hundred cells are empty and falling into ruins, for now there are only thirty monks left. Conscription and education are rapidly striking a deathblow to the monastic institutions in the kingdom of modern Hellas.

Just above the monastery there is a curious pointed rock, to the summit of which nobody knows how to climb. On the top are evident traces of a wall; probably, as Superior Gregory suggested, this was the former home of some hermit, which has been rendered inaccessible by the falling away of a portion of the cliff.

In a storm of sleet, and with a biting north wind behind us, we set out from our somewhat dreary haltingplace on our way across the mountains which lie at the back of Panáchrantos, and divide the vale of Andros from the parallel vale of Korthi. To our left we passed 
one of those ruined Venetian fortresses on the summit of a rock, covered, as usual, with the ruins of towers, houses, and cisterns of the Latin epoch; and there is the usual saga concerning it about a bloody slaughter which once took place here between Venetians and Turks.

It was delightful to get down into the valley again, into a more temperate climate ; and the vale of Korthi, though greatly inferior to that of Andros, was genial and pretty. Not long ago a storm of sand invaded the valley; mulberry trees and cypresses stand quaintly out of sandhills which resemble the dunes of Holland; and the only effectual check to this invasion of sand seems to have been a bulwark of cypresses, behind which the gardens and towers of the Korthiotes have been protected from the destruction which has fallen on the fields outside.

Before entering the village of Korthi you pass a whole row of towers: this spot is called Kampana because the rich family of that name once owned most, if not all, of these towers. They are gaunt, imposinglooking edifices, buried in trees and surrounded by wellstocked gardens, for the Kampana seem to have been one of the wealthiest of the archon families of Andros, and they have still extensive property in the island, called, curiously enough, a feud ( $\phi \varepsilon$ cov $\delta$ a); a singular transplantation of a truly Western word on to Hellenic soil ; and the chief families of Andros-Kampana, Kaires, and Della Grammatica - though Greek to the backbone now, have a distinctly Latin origin. Another Latin influence in Andros is likewise curious : a baby, before it is christened, as we have seen in other islands, is called 'Dragon ' or 'Iron'; here in Andros it is called 'Paganos,' or 'Pagan.' 
Our destination to-clay had a pleasant-sounding name, 'A $\eta \delta$ óvıa (Nightingale), where dwells the chief magistrate of the deme of Korthì. 'Nightingale' is a little village above the town of Korthì, where the wealthier inhabitants now dwell in their large towers. Our host was quite an aristocrat, belonging to the archon family of Kaïres, who had married a Kampana. He lived in a very large tower, approached by an imposing flight of steps, from which we entered directly into a fine room, where the family receive. Behind is the dining room and the kitchen; above are bedrooms; and above that the dovecote; on the ground floor were the offices and stables: such is an Andriote tower. Korthi and Aedonia must at one time have been entirely composed of them, rivalling the surrounding cypresses in their growth.

I was glad to come across one of this Kaïres family, though perhaps to anyone not conversant with the incidents of the war of independence the name may not convey much. Theophilos Kairres, of Andros, was one of the most brilliant lights of that period. He left his native island when quite young, and learnt in Europe more than the ordinary routine of a merchant's life. Impressed with the oppression of his country, he hurried back thither, seeking an opportunity of preaching emancipation and freedom. He had, of course, wonderful hair-breadth escapes, like all the heroes of those days, and when all was over, and freedom declared, he quietly set himself to carry out his great hobby-that of establishing an orphanage in Andros. Capo d'Istria wished him to take the head of an orphanage in Egina, but he refused, so determined was he to erect his building in his native island. With this object in view, he travelled the length and breadth of Europe, collecting money for 
his purpose. He was most intimate with and got most support from the Quakers and other European Nonconformists; in fact, Kairres was anything but orthodox in his views, the result being that when, in 1835 , his orphanage was established, and thirty orphans from various parts of Greece were being educated under his wing, the orthodox Church began to grumble. Though he had the support of the Government, and King Otho offered to decorate him with the Order of the Saviour, he refused everything, and left his school in the hands of a deputy, whilst he wandered about abroad until the animosity against him cooled down; then he returned and continued to manage the school till his death in I 853. When in the capital we visited the building he had erected, which was closed for twenty years after his death, but now is opened as the Government school. The love of Theophilos Kaïres is not yet dead in Andros; he is undoubtedly the greatest light that has ever shone amongst them.

Demarch Kaïres and his wife were naturally proud of their illustrious kinsman, and told us much about him. Nowhere in Greece have I ever seen family pride so marked as it is here; the half-century of democratic Greek rule has not sufficed to root it out. In Athens it is the fashion to laugh at this sort of thing; those who come from the Ionian Islands, and call themselves counts, and those whose fathers have been hospodars under Turkish rule, and still call themselves princes, are ridiculed by the democratic element; and the archons of Andros come in the same category.

After our monastic experience we felt ourselves once more in the lap of luxury; we were allowed to cook our lamb without any demur; and the demarch, after a little persuasion, partook of some himself, for it is the same 
in Greece as it is all the world over-the women are supposed to do the greater part of the fasting and church-going. Here we got for a change some decent bread-not that brown rye-bread which feels as if it were half made of sand-and some good biscuits, too, made of barley-bread mixed with anise-seed, crisp and hard, which you are supposed to dip into your coffee or wine.

'Nightingale' is worthy of its name, full of rushing streams and shady walks, where the nightingale is really. to be heard. It is far superior to Korthi, down in the hollow by the sandhills; and in summer it must be a delightfully cool retreat. Korthi, however, can boast of some interesting churches, one of Byzantine architecture, of very early date, and another now in ruins, but in its ruins most picturesque-so buried in olives and fig trees that it is hard to effect an entry-and the roof is covered with wallflowers and has a cypress growing on the top of it, by some odd contrivance of nature.

The vale of Korthì is quite shut off from everywhere being surrounded on three sides by lofty mountains. To the south the land continues rocky and barren to the southern cape, close to which is a now desertec monastery, where in former years was the great 'pane. gyris' of the Cyclades, before the Evangelistria at Tenos was invented. Everywhere the same complaint is made, ' Before the world went to Tenos they came here ; nearly every island complains of the disrepute intc which its miracle-working shrine has fallen within late years.

It is strange that all along this eastern side of Andros where everything now is so fertile, there seems not to have been any ancient settlement. I fancy the ancient Greeks had a righteous horror of the north winds; it is 
the same in nearly every island. The old town stood on the western or southern slopes, nestling under some cliff, regardless of the absence of a harbour or of land to till in its immediate neighbourhood.

Next day we went westwards up the vale of Korthi, warmed by a sun worthy of an English July, which made us thankful for the occasional shade of the oleanders and olives; but on the mountain summit again we were shrivelled by our everlasting enemy, King Boreas. Even in the summer heats the cold on these mountain-tops is intense, they say, whenever the hurricane comes from the north, and when the waves, as Hesychius puts it, resemble so many goats skipping and bounding in the fields.

\section{Western Andros and its Antiquities.}

Everything seemed changed when we left the valleys; these mountain barriers are almost as effectual as the sea. Western and Northern Andros offer quite a different aspect of affairs. We were once more in the land of antiquities, and, furthermore, we were in the land of Albanians, not of Greeks. Alone of the Cyclades, Andros has been subjected to a Sclavic wave, and this wave has only swept over the north and west. In the north, dress, language, and customs are all Albanian; where we had been they were either Greek or Italian. In this way it is easy to see where the wave stopped, and how far the Greeks of to-day have been subjected to the Albanian influence. The Cyclades have, except in this remote corner of Andros, entirely escaped, and, cxcept in the larger islands - Andros, Naxos, Santorin, and Tenos-the Italian infruence has been but little felt. The islands for the most 
part are barren, and have not been sought after as hunting grounds by alien races; hence the Cyclades present a more favourable field to the study of Hellenism than almost any other portion of what was once Hellas.

The view from the highlands of Andros, as we began rapidly to descend the more precipitous slopes of Western Andros, was very fine; another of those ever-varying groupings of islands which form the charm of every view in the Cyclades. Close to us now was the isle of Gyaros-just a large barren rock, uninhabited, except in summer time by herdsmen. I had a secret wish to visit this island, remembering that in the days of Tiberius there had been some talk of sending Silanus and Vibius here in exile, but that the serrate had voted this punishment inhuman, and had chosen Amorgos instead. In Juvenal's time the horrors of banishment to Gyaros were proverbial. I thought, perhaps, there might be traces of Roman tombs and inscriptions; but then I read what Tournefort had to say about it: how he found three peasants there, who ate his biscuits because bad weather had prevented the boats from coming: and he thus quaintly concludes :- ' I found nothing but field mice, of the same race, perhaps, as those which Pliny describes as driving out the old inhabitants.' So my ardour was damped; I decided to limit my visits in the Cycladescertainly in winter time--to inhabited islands.

Palæopolis, as the Andriotes now call the spot where the ruins of the old city still exist, is a heavenly place. When the temples and the public buildings stood here it must have been one of those ideal places which we see depicted on theatrical drop-scenes. Everything that nature can provide is granted to this spot. Behind it rise the precipitous heights of Mount Petalos. Two clear streams dash down the slopes, amidst olives, cypresses, 
and lemons, which grow in profusion here. Below is the sea-and not a breath of that biting north wind which had tormented us so on the heights-everything was genial and pleasant except, perhaps, the interior of the peasant's house in which we had to sleep. There are just a few cottages here, inhabited by the owners of the soil, who live, as they told us, a truly 'peaceful life,' rarely' seeing any visitors from the outer world - not even from the capital. We were accustomed by this time to mud floors and black cupboards for bedrooms, but somchow this abode at Palæopolis had even more horrors than most. Our hostess laughed at our dismay at the constant hopping about of obnoxious animalcula.

Up in the mountain, down in the plain,

Right in the middle my enemy is slain.

This little homely Greek distich illustrates our chief indoor occupation at Palæopolis.

The old woman was busy netting silk fishing-nets for her son, and her old blear-eyed husband was busy maring a plough in the shed outside, just hacking away at the stump of a tree with the most primitive instrument the iron age could produce. On the wall of this shed hung a skin, which he told me was his $\phi \lambda a ́ t s$. Now at first sight the word does not convey much, but I had seen it before at Tenos called a $\phi \lambda \lambda^{\prime} \kappa \iota$, and in other places a $\phi v \lambda a ́ k \iota$, or thing for keeping or guarding the grain in when it has been threshed on the threshing floor; and if you open Aristophanes ('Plut.' v. 763) you will find exactly the same word describing exactly the same thing. The Andriotes are very much given to contracting their words and of making words out of whole sentences, so their dialect is excessively difficult to follow.

Without regret we left our humble abode and spent 
the afternoon amongst the ancient ruins. Though there was only one town in Andros, properly so called, it must have been one of considerable importance, for Andros was taxed by Athens at the same ratio as Naxos and Melos; and from the extent of the walls, the statues, the inscriptions that have been discovered here, we can argue that it was a town of some size. Every building in Palæopolis, church or cottage, has some trace to show of antiquity; but excavation here would be difficult, considering that the whole area which the town occupied is now one large garden planted with trees, and there is a considerable depth of soil, which has been washed down from the mountains, and intercepted on its way to the sea. In digging they sometimes come across remains three or four yards below the present level of the soil.

In one of the two mountain streams are the columns of an ancient white marble temple, the gateway of which can still be seen; just a wide doorway on a terrace, probably a temple of Apollo, for it contained a votive tablet, which is still to be seen, let into the house of one Demetrius Sterianus. In a barley-field we saw the headless torso of a woman and child, and on a big stone by the wayside, in rude letters, was cut $\triangle I O \Sigma$ EAIXIOY. It is not likely that all the ancient inhabitants of Andros actually lived in this one town; the presence of towers along the western coast argues that villages and cottages for farmers, perhaps like the mandra of to-day, were scattered about, and of this inhabited stretch of land the haven of Gavrion must have been the port. As for the town itself, it was built on an open roadstead, and could not be approached when a southern gale was blowing. In one of the houses of this village Ross found his hymn to Isis cut on an oblong slab of white marble and in- 
scribed in columns, and in nearly every house we saw inscriptions for the most part turned wrong way up, and carefully covered with whitewash.

The acropolis of Andros is a good climb from the town, and on the top of it is the basis of a square tower and traces of brick pipes, up which presumably water was carried from the hill above to the top of the tower; and by its side is the little yellow church of St. Demetrius, containing an inscription.

It is curious to hear local legends about these towers. Two brothers built two towers, of which the one of St. Peter at Gavrion was so much the best, that the other brother who built this one of St. Demetrius, on the acropolis of Andros, was jealous. So he invited his brother one day to dinner, and took him to the top of his tower, and whilst he was engaged in admiring the view, he threw him over and killed him. A parallel to this might easily be found on the Rhine or anywhere in Western Europe.

Saturday night we spent at Palæopolis; an evermemorable night of misery. It was the first Saturday in Lent, a day on which the pious Andriotes do not work in the fields; so we had the pleasure of the company of the whole family, a most inquisitive, ungainly lot.

In the evening some girls came in with branches of olives in their hands, and there was evidently going to be some most exciting entertainment in which the young men and the young women were greatly interested, so we watched them closely. Presently one of the girls threw a sprig of olive into the embers of a brazier, saying as she did so, 'Does Andreas love me ?' Then a young man did the same, mentioning the name of some girl. On inquiry I was told that this is a common custom here on the first Saturday of Lent: if the leaves of the 
olive twig crackle and leap out of the fire, it is a sign that their fondest hopes of love will be realised ; if, on the contrary, they burn, it is a sure sign of disappointment.

Next morning, very early, we set off for Mpatzi, where first we became merged in Albanian life. Here the women wear the Albanian costume as in Attica, but the men do not wear the snow-white fustanella, so associated in our minds with the pallicari of the mainland; but they have adopted the ordinary island costume of wide

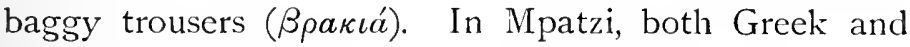
Albanian are spoken, but north of this we became immersed in the latter speech only, and consequently were debarred from free intercourse with the peasants.

There is no record of the time when the Albanians found their way to Andros; only a tradition, undoubted! $y^{\circ}$ true, that centuries ago their ancestors crossed over the narrow straits of Doro from Karystos in Eubcea, and settled in Gavrion; and yet the place names of northern Andros are unchanged from the day's of antiquity.

Mpatzi has a comfortable little harbour full of fishingboats, but nothing more. All the boats here have the step on the stern, on to which the fisherman leaps when he has pushed his craft off the beach ; they have huge iron rowlocks and unwieldy oars. We saw, too, a curiously contrived boat for shell-fishing fitted with an iron triangle which is let down into the sea with a net; this triangle scrapes the shellfish off the bottom, and then they are caught in the net. This they work by means of chains and a wheel in the boat. It is tremendous labour, and requires two men to turn the wheel, whilst a third rows. So

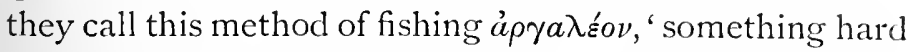
to do,' like the women's handloom.' During Lent shellfish, and especially cuttle-fish, are very much sought after, 
and eaten in large quantities; the shell of the cuttle-fish comes in handy for spoons, and for bait to catch other cuttle-fish. I am sure that if some enterprising Englishman would boil, pickle, and send out to Greece the cuttlefish we throw away in disgust, his fortune would be made.

The damp of Panáchrantos and the sudden changes of temperature on our journey, had now asserted themselves, and before reaching Gavrion that evening symptoms of fever had set in. Nature, not art, cured me, for Gavrion does not possess a doctor, only a deaf old man who knew something about herbs, and whose presence half-a-dozen times a day in my room was worse than the fever. I think he fancied I was going into a consumption-a common disease, I believe, in Andros, and which the peasants believe to be the Erinys, who sits at the four corners of the death-chamber ready to seize on any who come near. Hence consumption is said to be infectious: children and newly married people, whom it is supposed the Erinys chiefly attack, are forbidden to come near the sick-chamber.

Of all places in the world Gavrion is one of the most desolate. A few houses are dotted along the shore of a spacious land-locked harbour ; before these houses stand tall wooden erections that look like gallows, but they are merely places on which to dry the bodies of the octopodia in the sun and wind. There is not a tree in sight, only a marshy plain dangerous from its miasma in summer, but when we were there a perfect garden of sweetsmelling narcissus. The most interesting sight we saw at Gavrion, on the Saturday after we arrived and the first day I was able to get up, was a troop of Albanian peasants, who came in this day to have their cases of litigation settled. The Greeks say that they are ten times more quarrelsome than themselves, and bring their 
women too as witnesses, in their long white dresses and embroidered cloaks. In the afternoon most of them got drunk on the mulberry liquor, and thereby laid the seeds for future quarrels and litigation.

Gavrion has no protection from the north winds, which rush down upon it from the lofty mountains of Eubœa, and do great harm to the crops. On this account the threshing floors near here are surrounded by huge tall slabs with a narrow opening to the north, so that just enough wind may enter to assist in winnowing the corn ; otherwise all the straw and corn would be scattered by the blasts.

The inhabitants of Gavrion, too, struck us as mornse, and not too hospitably inclined. We had a letter to the demarch, who as a matter of course received us; but he and his wife never appeared during our stay, and left us alone to our frugal meals: perhaps they thought I nad an Erinys or some other infectious malady. All the time we were there we only saw a little maidservant aged seren, who attended to our wants.

At Gavrion there are evident traces of antiquity; doubtless it was the port of Andros in ancient days, for there are several towers built near it, and it ought to be the port of Andros to-day if there was sufficient energy. to open roads, so that the lemon trade might pass through here instead of depending on the dangerous port of the present capital.

Before leaving Gavrion we took an easy excursion to the Albanian village of Phellò, a clean, hospitably-inclined place, very picturesque, and with houses for the most part decorated with old china plates built into the walls. On one house we were amused to find a willowpatterned plate thus honoured. They have glorious views from here over the snow-capped peaks of Euboea, 
and the dress is quaint, like those you see as you drive trom Athens to Eleusis. They make sacks too, which they embroider with uncouth patterns of their own. They are as different as possible in expression and type of features from their Greek neighbours. I was told they were very superstitious, and I should have liked to have collected a few of their beliefs, so as to compare them with those of the Greeks, but their tongue was an effectual barrier to conversation.

Close to Phellò we visited an ancient marble quarry, where are still to be seen huge blocks of marble cut out of the cliff ready for transportation. The quality did not look to me so good as even that of Naxos, but tradition says that the white temple of Apollo at Sunium was built of it.

Without a pang of regret we turned our backs on Gavrion next day, and set off to see the old round Hellenic tower of St. Peter-a fine object on the hillside, surrounded by olives, and just below a hamlet of the same name, about half an hour's ride from Gavrion harbour. The stones of which it was built have become rich and mellow with age; they are colossal at the foundation, and diminish in size as they go up. As the tower of St. Peter is one of the most interesting relics of ancient Greek strategic art, I will give a minute description of it in a note.

After leaving the tower we went on to the neighbouring monastery of Hagia, to which the tower belongs; mentally resolving that, if the accommodation was not superior to that of Panáchrantos, and if our prospects of food were no brighter, we would push on to the next village, where we were sure of a good reception and decent accommodation.

() utside, like all Greek monasteries, it was forbidding enough; just a fortified mass covering an acre of ground 
on the top of a hill, so that there was no doubt about its being cold, but inside affairs looked more promising. A jolly fat superior met us in the guest-room, which was heated for our benefit, as they had received intimation of our intended visit, and next to it was a comfortable kitchen; and it appeared that no restriction would be put on eating, for a fowl was already in the stew-pot, which sent forth grateful odours to our nostrils. When dinner time came the superior and the archpriest, Bishop of Stavropolis-who had retired to his native monastery to end his days-sat down with us and enjoyed their cuttlefish and pickled octopus, whilst we discussed our soup and fowl.

The bishop was a highly intellectual and pleasing man; he has produced a monograph on the celebritics of Andros, with a copy of which he presented me, and he has actually managed to get together twenty-one, beginning with an Andriote who won a wrestling-match in the Olympic games prior to the Median wars, and ending with one Kotakes, who distinguished himself in the last war between Russia and Turkey. Theophilus Kairres, whom we already know, was by far his greatest character, and to his life most of the pages of the brochure are devoted.

As usual, we were waited upon by a deformity-a little hunchback this time-whose rapidity at vespers that night in saying his Kyrie eleisons was little short of a miracle. After dinner we sallied forth to visit the monastery. It does not possess half the attractions of Panàchrantos; the church is inferior in beauty, but behind the high altar there is a curious cave, which you have to enter on hands and knees. Here is the sacred source $(\dot{a} \gamma \iota a ́ \sigma \mu a)$ from which the name of the life-giving stream has been given to the monastery. The water in this tank is subject to a curious incrustation, which, when 
we saw it, resembled a thin layer of ice, but they say that in summer time it becomes much thicker. This is the miracle-working stream. Is it not possible that here we have the source which at certain times of the year was supposed to turn into wine? It is far more likely that a temple of Dionysos stood here than at Menites, for all about here are traces of ruins. It is close to the tower of St. Peter, and within easy reach of the old town and the port, and the position of the stream is such that an ingenious priesthood could easily effect a miracle; and, furthermore, in the early days of Christianity monasteries and churches bearing the name of the life-giving stream were generally built over a stream which in the old cult had been accredited with miraculous powers. This is only a speculation, but it appears to me a possible one.

No one knows when the monastery of Hagia was founded; all we know is that it was in existence in 1533 , for the Bishop of Stavropolis showed me a document of that date recounting a large grant of land, stretching from sea to sea, in Andros, given by one Stratopoulos of Sparta, who seems to have renewed the monastic building, and further endowed it; and then there was another grant of land from his widow, who inserted curious conditions in her grant-first, that she should be entered as a sister, and then that, when she died, all the monks should follow her to her tomb.

We visited several of the cells, and amongst others that of a very aged monk with one foot in the grave. Owing to his infirmities he was allowed to have his sisterin-law to live with him inside the monastic walls, to administer to his wants.

The great attraction of this monastery is its library, containing some very old and valuable illuminated 
manuscripts. One gospel bears the date i i 56 , and has illuminations and quaint pictures of the four evangelists at the beginning of each gospel; from verses at the end we gather that it was written for the Very Holy Archbishop of Cyprus, John. Some of the verses at the end of these manuscripts are interesting, as showing the intense labour, and the intense relief of a mediæval monk when he had accomplished his task 'with trouble, sweat and labour,' as they say. One of these is a musical Psalter with dots for the music, and the words beneath the dots: a work of exquisite toil, of a lifetime almost. Appended are some expressive verses, of which the following is a literal translation :-

As a traveller rejoiceth

His country to see;

As a mariner yearneth

In harbour to be ;

As a merchant enjoyeth

The gain that's accrued ;

So it pleaseth the writer

His book to conclude.

This library contains also a perfect copy of St. Polycarp's epistle to the Philippians, and one of the most beautifully illuminated liturgies of St. Basil I ever saw.

We had a pleasant evening with the monks, who gave us a warm dry bed, so when we left next morning we felt more charitably disposed towards monastic institutions.

Certainly, in travelling through the isles of Greece, we became acquainted with varied hosts and strong contrasts. Our next journey took us to a village called Katàkoilos, in the heart of the Andriote mountains, and here we were taken in by Mr. Zaraphonides.

Now the possessor of this long name was an Andriote by birth, but had passed most of his life in America; 
there he had joined a religious society, members of which bound themselves by an obligation to devote twelve years of their life to missionary labour. Knowing the superstitions and the ignorance of his relatives at home, Mr. Zaraphonides thought that he could do no more valuable work than in his native Andros. Accordingly he married a charming young American wifc, and two years ago he brought her to Katàkoilos, to a cottage with a mud floor and no glass in the windows, and to a mother-in-law with bare legs and witchlike appearance.

In these two years they had wrought wonders in the house: the mud floor had given place to boards, the charcoal brazier had given place to a stove, glass windows were put in, and an air of comfort reigned therein; but with the old mother-in-law and the neighbours their success as yet had not been marked. When her grandchildren were born, the old crone insisted on going through her incantations, in spite of all her son could say, and she interferes with the household arrangements whenever her superstitions prompt her. she had been exceeding wroth with her daughter-in-law for lending a neighbour some wood on the first of the month, a sure omen of impending poverty; she was most careful to see that the yeast for the family bread was never exposed to the stars for fear of sickness, and the did not take kindly to the principles of teetotalism inculcated by her son. Nay, she even insisted on having her own barrel of wine in the cellar, out of which she could draw a gourdful to offer to any strangers who came, in conformance with the Andriote's law of hospitality. She was a curious old woman-dirty, unkempt like her neighbours, talking an almost unintelligible patois, of a truth a real trial of a mother-in-law-but 
the neighbours told me that the soft winning ways of her daughter-in-law had done far more towards subduing her hardened heart than all the lectures of her son on teetotalism put together.

Thanks to our host, I was able to understand all she told us about vampires and bugbears. She affirmed that she herself had heard the bones of a young woman rattle in the grave, and that, owing to the general dread, the priest had been persuaded to open the grave, and lo! they had found the body undissolved - a clear proof of its ghostly properties. So they had cut it into shreds and burnt it. This happened only a few months before our visit.

Certainly the Andriotes are most hospitable; nothing that the Zaraphonides could do, short of a glass of wine, was left undone; and next morning we started laden with provisions for our way, which led right across the mountains towards the capital. Luckily it was a lovely day, for we had to cross over fields of snow and streams still hard with ice, and when we had crossed over Mount Petalos we were once more in paradise, that is to say in Lamyra, one of those enchanting villages on the southern slopes of Mount Petalos, just above the town. Olive trees of huge girth and tall cypresses shaded our path, garden after garden of lemon trees, laden with their yellow fruit, so closely packed together that the paths between them are not wide enough for two laden mules to pass: and through this clustering foliage you dimly see the bluish mountains across the vale, and the still bluer sea beyond.

Here we had further instance of Andriote hospitality -a hospitality that gives freely and asks no questions. Our pockets were never free from quinces, oranges, and lemons, given us by people whom we heard ask one 
another, 'Are they Christians ?' and receive for reply, 'No ; lords.' We were having our midday meal in a wineshop at Lamyra, when up walked a delicate-looking elderly man, and inquired of our muleteers if we were having a picnic. 'No,' replied they, 'they are travellers.' Without further question he came up to us and bid us welcome. 'Will you come and take coffee at my house close by ?' he asked ; and we, thinking it a pity to refuse so good an offer, followed him to one of those large white towers of the archons, and were introduced to his wife, a pretty faded woman called Kyria Evanthea, and three delicate daughters.

Rather to our dismay we found seated at table our old friend Superior Gregorios of Panáchrantos, and another monk; they had dropped in for a midday repast, and ate far more heartily than we could have given them credit for. In fact, Kyrios Parodes-for that was our host's name-had quite a large gathering at his house: his two sisters, and a brother, a pricst, with whom we were begged to sit down and partake of the meal that was spread. The priestly brother was by trade a watchmaker, and sat hard at work all the afternoon in a window with his tall black hat on, black cassock, and magenta trousers, for somehow the priests' trousers here are treated like ladics' petticoats, and their colour is a matter of little moment.

Presently our host asked where we intended to sleep that night, and we replicd that it was our intention to present ourselves at the eparch's door and ask for shelter till the steamer came.

'But the eparch has got the nomarch of the Cyclades staying with him just now ; he cannot take you in ;' and nothing could satisfy the kind hospitable man but that we should stay with him for the night. 
All Lamyra came to afternoon tea, or rather sweets, to meet us; then we were taken for a walk next morning, and to call upon the brother of our hostess, who lived in a neighbouring tower, and who was arrayed in a peacock satin robe, a dull violet satin overcoat lined with yellow fur, a red handkerchief round his neck, and a fez on his head: he was a handsome picturesque man on whom the name of Archon Kaires sat well. Thus pleasantly ended our stay in Andros, in the lovely village of Lamyra. Half an hour brought us to the town and the steamer next morning.

\section{NOTE.}

\section{On the Round Hellenic Tower of Andros.}

The tower of St. Peter is round, and rests upon a circular foundation, which is a little over twenty-three yards in circumference, and projects a little over a yard from the foundations of the tower itself. This foundation is about four and one-third feet high, and is built of colossal stones, some three, some four yards long, and about a yard is a good average thickness. This foundation is what usually would be called Pelasgic, whereas the tower which is built upon it is in a much more advanced style, having the stone carefully levelled on the outside, and chiselled up to the very highest storey.

The entrance is to the south, and there are three windows over it ; besides this the tower has three other windows or apertures, perhaps for discharging missiles out of. The door is exceedingly curious, being only a yard and a half high, and made of four huge stones, two of which form the jambs and the other two the threshold and lintel, and rather remind one of the door into the treasury of Atreus at Mycene in miniature. The width of the door is one yard four inches, and the stones of the threshold and lintel are longer than this, and project into the walls on either side so as to form a support. Anyone entering this door must naturally stoop to go in, and in doing so will consequently lock down. When he gets into the circular room inside, he will be surprised not to see any staircase leading up to the higher storeys; but on examining the doorway again he will find that there is a hole in the ceiling of 
the long low entrance, like a chimney, answering a double purpose ; first, if an enemy who is ignorant of the construction of this tower tries to enter, he can easily be struck down through this aperture above him whilst he is stooping; and, secondly, it serves as a staircase to the first storey, to ascend which projecting stones for footholds are left in the sides. This curious chimney staircase is constructed in the thickness of the wall, admitting only one person at a time, and it goes no further than the first storey.

The circular room entered by this doorway is five yards three inches in diameter, and has a vaulted roof-that is to say, the inner part of the outer wall gradually inclines upwards to a point like the roof of the treasury of Atreus, caused by the overlaying of the stones, and the top being formed by radiating slabs. The walls on the inside are smooth, and on either side of the door are two niches, through which a small amount of light can penetrate ; outside they are mere holes, but they increase in a triangular form as they pierce the thickness of the wall.

On ascending the chimney staircase you reach the second storey, which is chiefly taken up by the dome of the vaulted roof of the first storey : and from here starts a spiral staircase, which goes up to the topmost storey, but of which only twenty-five steps are now left, made of huge stones set into the outer wall, and projecting one yard eight inches inwards; and along it are little niches for the introduction of light. Up to the summit of the tower there have been six storeys, but without a ladder it was impossible for me to reach the summit. A window over the entrance door, similar to it in size, lights the second storey, and in the walls are holes in which probably beams have been placed to form floors for the different storeys. The inner wall of the tower from top to bottom has been constructed with much smaller stones than the outer, and well fitted together with cement. There is no trace, as far as 1 could see, of the roof. Over the window of the second storey is another smaller window, and over that a bigger one. To the left of this last there is a straight slab walled in as a protection to the window, and there are two more windows, one over the other, for the storeys above this.

On the outer wall of the building appear four square shallow furrows running from top to bottom, which at first sight appear to have contained drain pipes from the roof, but then they are too carefully executed for that; it is just possible they may have served some military purpose of which we are now ignorant. 
This tower of Andros is a venerable relic of the past, and deserves to be carefully preserved; but I fear the tendency is towards destruction. Grass is growing luxuriantly over the vaulted roof on the first storey, now ruined in the centre; cattle find shelter here from the cold and sun ; and then the topmost storey looks in a very tottering condition, and if it falls it will destroy the vaulted roof and other points of interest below it. The monastery of Hagia, to which it belongs, has no surplus cash to spend on what the superior called ' useless ruins.' So, unless some enterprising archæologist like the prince of Bavaria, who bought the theatre of Melos, comes forward to rescue it, a valuable relic of the past will be irretrievably spoiled. 


\section{CHAPTER XIII.}

SYRA, THE CAPITAL OF THE CYCLADES.

()F all the Cyclades none is so bleak and barren as Syra, ret this island possesses an attraction of her own, and a curious history of modern development ; future ages will quote this little spot as the brightest specimen of activity produced by the revival of the long dormant spirit of independence in Greece. Athens has been forced into a modern existence by the necessity of having a capital somewhere. Patras has flourished because the site of that capital was foolishly, through sentimentality, chosen on the eastern coast, whereas the existence of Greece to-day is due to the West, and all her interests lie in the West. But the flourishing commercial centre on the island of Syra is due to the spontancous outburst of incrcantile activity incident on the recovery of freedom. Thus in many ways Hermoupolis, on Syra, is one of the most interesting towns of the Levant. Whatever was left of vitality in Greece after long years of depression found itsclf drawn to rocky, ungainly Syra.

It is a night's journey from the Piræus to Syra by steamboat, and the effect of the place is curious as you pecp out of your porthole on the busy harbour teeming with gay-coloured caíques and stcamcrs from all parts of the world. It is ajt to remind the traveller a little of fenoa, only Syra is almost entirely a white town, relieved 
now and again by a dash of yellow wash. Houses, one above another like the steps of a staircase, completely: cover two hills and surround the bay in the form of an amphitheatre. One hill is crowned by the mediaval town and its Latin church, the other by the modern Greek town and a Greek church. The background is formed by the rocky bleak mountains of the island, so barren and so treeless that one wonders if this can possibly be the spot which Homer describes thus-

Of soil divine,

A good land teeming with fertility,

Rich with green pastures, feeding flocks and kine.

A fair land with streams, a land of corn and wine.

WORsley', 'Od.' xv.

Even the butter consumed nowadays at Syra is brought from Athens. In the town there are no wells; all water is brought in carts from some distance, cxcept what each houscholder catches in his private tank. Little rain falls here, hence in summer the water-carts are the only means of providing a supply.

German critics have been inclined to question the identity of Syra with the above passage in the 'Odyssey,' chiefly because the poet called it by such fair names, but other writers besides Homer speak of the fertility of Syra. Anacharsis the younger calls it 'a fertile island.' and Tournefort, in 1699 , mentions secing the stems of great withered trees on the shore. Moreover, there are numerous traces of olive-presses, watercourses, and the like, and old coins of Syra have representations on them of Pan, goats, honey, corn, \&c., and in many places the nomenclature points to bygone fertility. The fact is, Syra has a good harbour, and no island in the Kigean Sea with a good harbour escaped from the ravages of mediæval voyagers, whether honest or piratical ; they 
cut down everything that grew, and left the place as it is to-day-a rocky waste.

It was a brilliant November morning when I reached Syra, and everything was life and bustle around the eggshaped harbour; all the boats were discharging cargoes, just now having run in with a favourable breeze. One highly-painted green brig with canvas bulwarks was unloading shaddocks from Naxos, and the island sailors with their blue baggy trousers, red fezes, and bare legs looked highly picturesque as they carried baskets of the freight along the plank which united the boat with the quay; another caïque was discharging small round cheeses from Crete, which were being arranged on long low barrows to be carried to the warehouses; another caïque, laden with lemons from Andros, was awaiting its turn. On every boat a mongrel was barking vigorously, men were chattering, and women were huddled up in corners looking the picture of misery. It is marvellous to see how wretched these island women are when on the water; though they have known no other mode of progression all their lives, they never get accustomed to the sea. The colouring of Syra harbour is especially pretty. Greek sailors love colour; their boats, their sails, and their dress are gaudy.

The quay, too, was gay with small hucksters' shops. One man had a pile of eikons, or sacred pictures, wherewith to tempt the pious about to start on a voyage, pictures of St. Nicholas being most numerous on his stall, for he is the patron saint of the seafarer ; another man had besoms, his neighbour sold Russian tea-bowls and large wooden spoons, whilst a third offered for salc brilliantly coloured handkcrchiefs, which, though made in Manchester, are particularly Eastern in appearance. All amongst these stalls the water-cart was threading its 
way, to supply the huge amplore which each householder produced as the cart went by with the daily portion. Far along the quay was the fish market, with strange sights for unaccustomed eyes. Advent was soon to begin - that is, the month's fast before Christmas-so there was any amount of octopodia in the market ready to be dried and stewed for this period. Sea-urchins, too, and bright red pinna shells, the contents of which form a substantial part of a Syriote's meal, this morning were plentiful, besides red mullet and haddock, which to us looked more tempting. In front of this market the boats of the Psariote and Hydriote fishermen, with their osier instead of canvas bulwarks, are lying. These men are the best fishermen in the archipelago; and if you desire to travel amongst these islands in spite of their treacherous winds, by all means choose one of them.

Syra boasts of two hotels, very passable for Greece, where travellers who venture beyond the capital do not expect luxuries. We were glad enough to rest in one after the voyage, and cast about us as to how we should pass our time.

'Syra,' wrote Tournefort in 1699, 'is the most Catholic island of the archipelago,' and singularly enough it is to Roman Catholicism that this spot owes its existence as a commercial centre. No one ever heard of Syra in classical times, except as a refuge for sailors. It was inhabited, it is true, and from time to time produces archæological treasures, but it never had the name that ancient writers give to Andros, Naxos, or Melos; consequently the first pages of the history of Syra begin in mediæval times, when it was chosen as a centre for Roman Catholic missions in the East. Under the Latin rule in the archipelago, Syra, doubtless owing to its good harbour and central position, recommended itself 
to the notice of the Capuchins, and on the top of the conical hill which is still covered by the old town they built a convent and a church. They were followed by the priests, and from this centre they sent out missions to all the neighbouring islands with such success that under the Turks, who treated the islanders always with consideration, there were in the Cyclades almost as many of the Western as of the Eastern Church. Naxos, Santorin, Tenos, Andros were almost subservient to the Papal See.

When corsairs and pirates disturbed them, the holy fathers of Syra made bitter complaints to the Roman Catholic powers in the West, and the end of it all was that Louis XIII. of France took Syra under his especial protection. From the convent on the hill the French flag was hung, and by this means the basis for the fortunes of Syra centuries later was laid.

From that time until the present day the Roman Catholic bishops of Syra have been elected by the Church of Rome, and from this rock they have made a desperate attempt to convert the Eastern world to their way of thinking; but since the war of independence Roman Catholicism has been unpopular, and must soon disappear under the present order of things.

Our friend Tournefort tells us of the prosperity of Syra even in his time, when only a few families lived in a cluster on the conical hill around the convent. He says he could not rest at night for the noise of the handmills for corn, or by day for the noise of the wheels which they used to thread cotton with; but it was refreshing, he adds, to see the French flag flying and to hear in churches, both Greek and Latin, this chant sung, 'Domine saloum fac regem,' to which they added 'nostrum Ludoricum.' 
This was the state of Syra at the beginning of the war of independence. According to Pasch van Krienen, who was sent to the islands by the Russians with a view to annexation, the inhabitants numbered only 1,000 souls about a century ago. The Turks knew them only by the name of taivshan or hares, for whenever a Turkish ship appeared in the harbour they would run up the hills, and could nowhere be found. What a contrast is this to the state of Syra to-day, being, as it is, one of the busiest marts in the Levant!

The freedom of Greece introduced an entirely new era into this island, and the circumstances occurred as follows: The great massacre of Christians in Chios and Psara drove from their homes some of the bravest and most commerce-loving of the Greek-speaking world. No tragedy in history is more thrilling than the story of this massacre ; unfortunately it is too near our own times for any of us to know as much about it as we do about the Sicilian Vespers or the massacre of St. Bartholomew. However, historians of future ages will rank it with these, and it will be one of the decpest blots on the annals of the nineteenth century.

After innumerable adventures by sea and land the refugees from Chios, rich men who had been nursed in the lap of luxury, found their way on caîques to various parts of Greece proper, where the standard of revolt had been raised, and where for a time they would be safe. Some went to Spetzia and Hydra, others further afield in search of a livelihood; but eventually all these refugees found themselves gathered around a few of the inore energetic spirits on the island of Tenos. The inhabitants, whose Roman Catholic, and hence neutral, proclivities were strong, did not receive them with favour; the plague broke out amongst them; commerce 
could not flourish, for the harbourage was bad in Tenos; so the refugees cast about in their minds for another asylum, and after mature deliberation settled on the island of Keos, the one of the Cyclades nearest to the Saronic Gulf, and the one which in all ages had been the commercial centre in the Egean Sea, during classical and mediæval times alike. To this island a deputation was sent, to make an offer for starting their commercial operations there instead of at Tenos. But the magnates of Keos, to their own detriment, flatly refused this offer ; they feared lest their island should be made a special mark for revenge if the war of independence went against Greece. So Keos pusillanimously elected to lose its name as the commercial centre of the Aggean Sea.

The arrangements made between the refugees and the inhabitants of Syra will probably never be known. It is more than probable that the leaders of the revolution had something to do in persuading them to choose this place, and thereby establish themsclves on neutral ground under the French flag. All that is certain is, that the refugees left Tenos in a body, and crossing over the narrow strait which divides the two islands, took up their abode on Syra, under the protection of the banner of France.

Before Greece was free, the town of Hermoupolis began to grow on the cliffs of Syra, holding, like Noah's ark, those that were saved from the cruelty of the Turks - suffering Greeks from Chios, Psara, Crete, Macedonia, Smyrna, forty thousand in all, found here a refuge.

At first the exiles lived in a miserable state, having huts by the shore, where now the busy quay is, in which they stored their merchandise and transacted their business, retiring to the upper town, Ano Syra as 
it soon was called, by night, to sleep in churches, stables, or wherever they could find a covering for their heads.

Before the arrival of the refugees, in June, I 821 , Demetrius Hypselantes, the great hero of the revolt, sent as his agent to the Cyclades one Themeles to inspire the islanders with the spirit which reigned on the mainland; but, with certain brilliant exceptions, such as Psara, Hydra, and Spetzia, the islanders were weak-minded, for the insular Greeks had for centuries had so easy a time under Turkish rule that they did not care to endanger themselves in the popular cause; at the time it was universally admitted that if the Chiotes had had any pluck in them they might have avoided the massacre and proclaimed themselves free. Some of the Cyclades at first flatly refused to join. Santorin, Andros, Tenos, urged by the Roman Catholic element in them, preferred to pay double taxes to both the Turkish and Greek fleets to declaring themselves on either side; and the inhabitants of Syra, advisedly perhaps, pointed to the French banner and replied that they were neutral.

It is not to be wondered at that these neutral islands were looked upon with suspicion by their fighting comrades; but when we learn that Syra received 40,000 refugees two years later, most of them incapacitated physically from bearing arms, being women, children, halt and maimed, we cannot blame them for inactivity. One of the colony, writing to the journal of Syra, in I 837 , gives us the following account of this colonisation of Syra :- Forty thousand Greeks, or eight thousand families, not being able to bear arms through physical incapacity, inhabited Tenos; of these some began to collect their goods together, with the aid of the ship "Hermes." But the absence of a harbour in this island, 
the pestilence which took place in I 823, political causes, and the unsuitable position of the island, compelled some of them to seek an asylum elsewhere - a safer and more suitable spot for commerce-and for this they chose Syra. Its broad and safe harbour, its mercantile position, the protection which its inhabitants received from the French Government as Western Catholies, moved those remaining in Tenos to follow the footsteps of the first, and thus day by day they collected from all parts, and were compelled to build a new city.'

So now we find our commercial colony founded and flourishing under the French flag. If there were some hard remarks made about the Syriotes who stayed at home and practised the arts of peace during the great national struggle, it is at all events clear that the leaders of the revolution understood the position taken up by them; and in fact the neutrality of Syra seems to have been a part of the plan of the provisional administration of the revolution, as many Syriotes afterwards let out. Many of them, though neutral, belonged to the

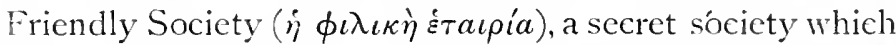
was the backbone of Panhellenism, and to Syra the Generals Miaouli and Mavrocordato sent their valuables for safety during the struggle. By correspondence which has come to light since, it is evident that the refugees in Syra were not at all unmindful of their struggling fellowcountrymen, and sent them frequent monctary assistance. For example, Andreas Miaouli wrote from the ship 'Ceres,' on November 15, I 823, to acknowledge having received 6,000 grosic from Syra.

All this time a town was growing up around the harbour and along the flat space between the harbour and the hill on which the old town was perched. The irst two-storeyed house was built in 1825 , and belonged 
to the first demarch, Petritzi by name, and it was considered a real phenomenon to look upon, for the island towns never indulge in two-storeyed houses as a rule, having flat roofs and ceilings, many of reeds, which they cover with seaweed, and on the top place a certain kind of clay which they trample down and then roll with marble rollers. After a rainfall it is a curious sight to see the inhabitants running about on their roofs to press down the mud, and kicking along with their feet the marble roller. But Syra has long since abandoned this style, and ever since Demarch Petritzi built his twostoreyed house in 1825 the town has adopted the Western style, and for all the world looks like a toin of France or Italy.

It was in this year that Luke Ralli and others, foreseeing a future of greatness for the infant city, thought it was time to give her a name, and not allow her, like all the other islands of the Ægean Sea, to have a capital called after and frequently confounded with the island in which it was situated. So they met together and called her Hermoupolis, the city of Hermes, for was not Hermes the protector of commerce among their ancestors? and did they not owe much to the good ship 'Hermes,' which had collected together the earlier nucleus of their trade? Just before this a church had been built near the sea, the Church of the Transfiguration, the outer court of which was still used as a hospital for those who were obliged to live in tents; and, situated as it was amongst wretched hovels, it was a perfert beehive, where the inhabitants could swarm and sleep if they wished. In the nave of this church the magnates of the refugees held their first public assemblies, and here it was that Luke Ralli for the first time pronounced the name of the torn - Hermoupolis. 
But the bulk of the colonists in Syra never intended to stay there if the war terminated favourably for Greek independence; they only intended to make of this barren rock a temporary asylum, as the Athenians had once made of Salamis: so when, in 1829 , the kingdom of Greece was established, there were many projects afloat for the re-colonisation of different parts of Hellas. Perhaps if Chios had been free the result would have been different, for the leading part of the refugees were merchants from Chios, and Syra might again have sunk into oblivion; however, as the Turks still held their home, the Chiotes elected to stay in Syra, and recognised Hermoupolis in Syra as the abiding centre of Greek commerce for the future. The position was good, being in the centre of the Egean Sea, in the highway of traffic to and from the East; the harbour was good, with two islands across its mouth to protect it from the south winds, but the island itself is wretched. No wonder the Chiotes sighed for their lemon and orange groves, the Cretans for their forests and olive gardens; no wonder they were anxious to get away from those brown hillsides, where nothing save aromatic herbs would grow, where there was not a tree to shade them or water to drink a sufficiency of. It is curious to see the results of reckless cutting down of trees here in Greece. The rains wash away the soil from the mountains and make them barren, and then there is nothing to hold the rain, which rushes off in torrents as soon as it has fallen, and thereby creates a drought. But commerce is in no way dependent on land attractions, as Venice and Holland can testify, so the Greek refugees who elected to stay at Syra had no cause to regret their decision.

At first they suffered terribly from pirates in the early days of anarchy after the establishment of the 
kingdom. Old people in Syra will still relate to you the dread these early colonists had of one Nestor Phatzole of Cephalonia, how he seized their merchant ships, levied blackmail, and scoured the archipelago ; but English, French, and Austrian ships year by year lessened the number of these marauders; and year by year, with the commerce of Western Europe passing through their hands, the Syriotes grew in prosperity, and their town of Hermoupolis sprang up with the rapidity of the mushroom towns of the western hemisphere.

It was just ten years after the naming of the town that Ludwig Ross visited Hermoupolis in his journeys through the islands of the Egean Sea, and he speaks with astonishment of the growth and almost magical development of this merchants' town.

Knowing the history of Hermoupolis during the last sixty years, we issued forth from our hotel with our interest keenly excited to behold, for here at least all around us was the work of modern Hellas. We hear much of the failure of Greece to carry out the hopes of the revivers of the nationality, but we learn, when studying the growth of Syra, that, given a fair, chance, the Greek of to-day will always come to the front in the mercantile world. The Powers created a kingdom out of a barren, unproductive country, sparsely inhabited, and without any of the sinews of wealth; they expected this country to produce at once all the fine qualities for which their ancestors had been celebrated, and were naturally disappointed.

We might as well take Cornwall and Devonshire and call it the British Empire, as consider the narrow limits of the present kingdum in any way representative of the Greek nation. The most prosperous, the most intellectual of the nationality are scattered over the face 
of the globe, in all the great commercial centres of the world. Here at Syra we learn what they can do when the chance offers. But what chance did the Greek kingdom ever have? The government naturally fell into the hands of a few uneducated men who were returned as members for semi-barbarous villages. As of old, every Greek is a politician, and for want of a clear head to guide them they fell to squabbling amongst themselves, until the Greek kingdom, instead of answering the requirements of Panhellenism, became a byword and a scorn. Of late years matters have improved considerably, under the able direction of M. Tricoupis; but a journey through the islands and the outlying parts of even this little kingdom shows how rotten the whole concern is. But Syra is quite different; if all the Greeks were like those of Syra, there could be no question as to who should rule at Constantinople.

An excellent street, the street of Hermes, branches away from the quay, and leads into a vast square, where in the evenings the inhabitants promenade to listen to the band. One side of this square is to be taken up by a large Hôtel de Ville; but this edifice progresses only slowly; the town authorities are careful, and only do a little now and then to it, when they have a balance in hand. Steep tortuous streets lead up one of the hills which is covered by the new town; everything is white and clean, a great contrast to a town of corresponding size in France or Italy; the drainage is excellent, and not a smell affronts the nostrils. There are plenty of churches now - none of any interest, to be sure, except that of the Transfiguration, where the assemblies were held, and where Luke Ralli stood as godfather to this infant town, now grown to maturity.

Of course Syra is now the central point of insular 
Greece; here resides the nomarch of the Cyclades, who superintends the course of justice in the eight eparchics into which the islands are divided; the eparchs, in their turn, look after the demarchs, or mayors, of the various towns and villages. In Hermoupolis is the jail where insular defaulters are confined ; the law courts are here ; in short, Syra is the modern capital of the Cyclades, whereas in the middle ages Naxos was the seat of government and the residence of the Duke. All this is due to the refugees and their commerce.

I went to the university, which, after that of Athens, is the most reputed in Greece, and there I listened to the various classes, the lessons taking for me a curious and decidedly interesting form. The pedagogues were holding forth on Herodotus, Xenophon, Plutarch, \&c. and the task of the scholars seemed to me marvellously simple, namely, to turn the ancient into modern Greek, parse the words, and collect the historical points. I could not help feeling what advantages these youngsters have over us, if a classical education is the only requisite, when a boy often can read and tell the contents of Xenophon with greater ease than an Oxford don.

On a subsequent occasion I paid a visit to the Archbishop of Syra, Methodios by name, a man of great liberal culture and enlightenment, who does all he can to combat the almost heathenish beliefs of the Greek peasantry. He has a large house, and wears a fine enamel, set in diamonds, and was very friendly, telling us as we sipped our coffee that he had seen our party returning on muleback from an expedition into the island, and added that we had called to his mind Christ's entry into Jerusalem. This is a marked feature in the Greek Church ; they are what we should call blasphemous. Curiously enough, a biblical comparison had 
occurred to us as to our appearance on the same journey, namely, that we resembled closely one of those many old pictures of a fight into Egypt.

There is, in spite of the newness of the place, a great reverence for antiquity in Syra, and a desire to keep up ancient associations; a newspaper here is called Pherecydes. At first I did not recollect that that eminent philosopher had been a native of Syra, and was astonished at the name.

Certainly Pherecydes was a man to be proud of, for many curious suppositions are attached to his name. He was born 598 B.C., and was master of Pythagoras. They say he had learnt from the Phœnicians, a colony of whom Homer speaks of on this island, the occult sciences of the East. To Pherecydes Cicero attributes the first idea of the immortality of the soul; others assert that he went in for the theory of transmigration. Altogether there is a halo of mystery about this man, so much so that bold theorists assert that he got his ideas from the secret books of the Phœnicians, which were no less than the books of Moses!

The story of his horrible death, and how Pythagoras came all the way to Delos to see his dying master, is told us by Diodorus Siculus; and curiously enough the Greek peasants of Syra have still a tradition that a great man called Pherecydes lived in the island, and was consumed by lice. Doubtless this tradition emboldened the publisher to name his newspaper Pherecydes.

Some of these traditions are very curious in the $\mathrm{Cy}$ clades, and busy, populous Syra is not without its own. It is a common belief amongst the peasants that the ghosts of the ancient Grecks come once a year from all parts of Greece to worship at Delos, and as they pass through Syra they are purified by washing; a cliff above 
Hermoupolis is still called $\Delta \hat{\eta} \lambda \iota$, where the country folks tell you this ablution takes place, and even to-day they will reverently speak of the 'god in Delos.'

They are vaguely aware, too, of a game called $\Delta i \sigma \kappa o s$, and say that their ancestors used two large stone olivepresses, which stand as reminiscences of ancient fertility in Syra outside a church, as quoits. How thoroughly Greek this is to believe in the superhuman strength of your ancestors; it is the survival of the idea which generated the myths of Hercules.

Passing on in our rambles, we came across the theatre of Apollo, than which no better theatre exists in modern Greece. Even Athens cannot boast of such. Curiously enough the piece advertised for that evening was The Pirates. I could not help thinking how short a time it was since the pirates had been a subject for more serious thought in Syra.

Beyond the theatre and the church is the west end of Syra, where stately mansions are built on the top of a cliff, overlooking the sea. These houses of Hermoupolis, like those of Athens, rejoice in a superabundance of marble. There are very few islands of the Cycladic group which do not produce marble, and at the north end of Syra there is abundance of it. Each balcony is supported by marble lions or griffins; the steps, the facings and window-cases of all the houses are of marble. A new road leading along the cliff beyond these houses forms the fashionable evening promenade for the Syriote ladies.

Though, perhaps, the rapid increase of Syra is now cooling down, nevertheless the place is still growing, and the small space of waste ground between the old town and the new is rapidly giving way to a mass of houses and factories; for with a central depôt for the Eastern 
Telegraph, and steamers of every company calling here, Syra cannot be expected to stand still. After a stroll through the factories and a visit to the centres of artisan life, there was little left to study in Hermoupolis the New; but Syra as an island, as we have seen, had a history long before its days of commerce, so to visit the various points of archæological lore we made screral expeditions about the island.

Alone of the Cyclades, Syra rejoices in the possession of roads, horses and carriages. Not that these roads lead you very far as yet, and only one may be said to have a destination ; this leads you to the harbour Delle Grazie, where in summer time the Syriotes go to take sea baths, and here are the remains of two ancient cities, from which we can argue that the much criticised Homer was not so far wrong when he tells us that Syra had two cities, 'Twain are the cities, and an equal share in all things is to either portioned well.'- 'Od.' xv.

It is true that the existence of a third city is proved by the ruins which have been found whilst building Hermoupolis. Onc inscription tells us of the existence of a temple of Isis, where now stands a great mavтo$\pi \omega \lambda$ siov (general shop), but it is highly probable from these inscriptions that the city, on the ruins of which Hermoupolis has risen, was of a more recent date, and that the inhabitants of Homer's two cities migrated at some time or another to the present site, for in Strabo's time there was only one city, which had in it a temple of Poseidon in the grove. Now an inscription (Iloosioovos ' $\lambda \sigma \phi a \lambda \varepsilon \hat{\imath}(\nu)$ has been found at Hermoupolis, and at the ruins of the city near Delle Grazie another inscription has been found, which was put up to Miagnas, a priest of Poseidon, and Amphitrite in the temple there. It is very probable that the inhabitants deserted this spot 
and went to the better harbour, for the bay of Delle Grazie is shallow, and exposed to the western winds. There are numerous traces of walls and graveyards at this spot, which is still called Poseidonia, and beyond, on the other side of the bay, are the scanty ruins of another town still called Phœnichos. Here is a little solitary. church, into the walls of which bits of marble have been let, and the flat land around is covered with bits of broken vases. In the sea, too, are ruins of some buildings, called now the little monastery, about which I can make no suggestion. It struck me as curious how this place got its name. Is it from the colony of Phœnicians here which Homer mentions? Ross calls it Grynche, and Pliny mentions a place in Syra called Eschatia; but Ross and Pliny are not always to be trusted. The former tells us that the silpressum used in dyes came from Syra, whereas it comes from the island of Scyros, or Skyros, ${ }^{1}$ and constant confusion in various authors has occurred between these two names.

All around the bay is barren, excepting where, here and there, like an oasis in the desert, the gardens of rich Syriote merchants relieve the eye. At one of these houses we were entertained hospitably by Mr. Tserlendi, and shown his garden and vineyards. On the way to Delle Grazie we saw many of these country seats, especially at Talanta, where money has had a veritable struggle with nature, and been fairly successful.

It is further presumptive evidence of the quondam fertility of Syra, that from an inscription we gather that feasts of Dionysos with singing contests were held here, which would never have been the case had Syra produced no more wine than it does now, with which to honour the god. In fact, the existence of Bacchic revelry

' An island of the northern Sporades. 
here in ancient times proves that they had an ample vintage.

One afternoon I strolled up the hill, to inspect the town of 'Upper Syra,' as it is now called, where the mediæval Roman Catholic settlement still exists; here everything is old world, and the inhabitants seem utterly unconcerned about the busy life in the lower town. The houses are like steps, one above the other; and the steep narrow streets, foul with refuse and tenanted by pigs, lead up spiral fashion to the convent and church of St. George, which crowns the hill. From the terrace in front of the edifice a fine view is obtained over the sea, dotted with Cyclades as far as the eye can reach; to the right is a brown stony valley, characteristic of Syra, and on the brow of the opposite hill a newly-fledged Greek convent seems as if it looked with contempt on the Roman Catholic town, as much as to say that its reign is over. Between the Eastern and Western Church there is no kindly feeling. On my way down to the lower town I met some girls who had strolled upwards to take the air. They asked me my intention on seeing me enter a Greek church, and on my inquiring if they were Westerns or Orthodox, they affirmed so eagerly that they belonged to the latter persuasion, that I was constrained to question them further on their knowledge of the relation between the two creeds.

One of them, who said she was a niece of Canarios, one of the great heroes of the war of independence, regretted loudly that shortly she was to marry a rich Roman Catholic; her principal objection being, from what I could gather, a current belief that when a Roman Catholic has received the last sacrament and shows symptoms of recovery, the priest goes back and strangles him with a rope, for after this sacred event no 
one is permitted to live. She was a young lady of considerable sentiment I imagine, for she carried in her hand a pretty flower which grows on the hills under the acanthus bushes, called 'patience' by the Greeks ( $\left.\dot{i} \pi \rho \mu \nu \eta^{\prime}\right)$, 'For when I look at it,' she concluded,' I feel strengthened to bear my lot patiently.'

By far the most interesting expedition we made into the remote parts of Syra was a weary long mile ride over the mountains to a spot at the north-west corner, where perhaps is the very place where Hercules was reported to have conquered the north wind. The goal of our ride was a point called Grammata Head, from the fact that it is covered with inscriptions. A wilder, bleaker ride I never had, even in the Cyclades. On leaving the town and ascending the hill of Deli, we were as out of the world as if no busy Hermoupolis existed at our feet. There was scarcely a mule track to guide us, and the rocks and stones by the way called for the exercise of all the agility our mules could display. All the way we never tired of admiring the ever-varying views over island and sea. Though Syra itself might be brown and arid, with occasional streaks of red from the nature of the soil, yet the halo of hazy blue islands around us, the sparkling of the sea, and the clearness of the air, dispelled all feelings of gloom, and made us realise that in those days when Syra was 'teeming with fertility' it must have been a paradise upon earth. No vegetation did we come across anywhere save aromatic scrub over the hillside, and the ungainly bulbous squilla marina, a source of considerable traffic in this locality. It was the Ist of December, and the sun was very hot. What must this shadeless place be in the dog-days?

We saw hardly any signs of habitation on our way until we came to a low whitewashed cottage, where 
lives, high up on the mountain-top, a tottering old man ninety-five years of age. He looks after a small garden, and whenever he wants anything he walks into Hermoupolis to do his shopping. Our mulctecr called him out, and he came to welcome us: he was full of stories about the wonderful changes he had seen during his long, eventful life; how he had fought for his country's liberties; how he had assisted in building the first house for the refugees down by the harbour. When we left him, I asked our muleteer if people frequently lived to be so old at Syra. 'Yes,' was the reply, 'an old woman died at one hundred and thirty only a short while ago ; in former years people lived so long that the aged had to be thrown down a mountain cliff which is still

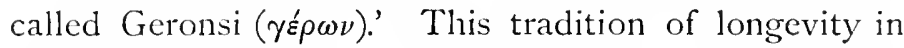
Syra is curious, and more especially so in connection with the slaughter of the aged. On the neighbouring island of Keos it is well known that the old and useless members of society were obliged to swallow hemlock when a certain age was reached. The Abbé della Rocca, one of the Roman Catholic brethren in Syra, writing a century ago, tells us of the same tradition existing then about the great age and general healthiness of the Syriotes. Homer gives us the following testimony-

There in the city, void of pain and fears,

They dwell, and ever as they wax in years

Apollo coming with his silvery bow

Aims with his sister the light-feathered spears

Agrainst them, and the sweet life fades like snow.

We rode on for some time after bidding adicu to our old man, and then our muleteers manifested a doubt as to the way. Luckily we came across two herdsmen who volunteered to guide us ; they refreshed us with dried figs and water, and were a pleasant addition to our party. 
All here was stillness and solitude save for the bleating of goats and the tinkling of their bells; goat-bells interest one in Greece, they tend to show how conservative the Greeks are in preserving the customs of antiquity. A goat's bell of to-day is of exactly the same shape and pattern as those the victims for sacrifice used to wear in ancient days. Turkish goat-bells and Albanian goat-bells are quite different; the Greeks still keep to their own old style. We passed close to a cave, reminding one of the habitation of a Cyclops, where 2,000 sheep and goats are kept at night, which wander over the mountain-side by day and gnaw the aromatic scrub.

The herdsmen were much quainter and more entcrtaining than our city-born muleteers. They had not deserted the ancient simplicity of accent and phraseology which Syra presumably possessed in common with the other islands of the Egean before she was converted into a centre of commerce. They were at first hard to understand, and made use of words which are strange to the modern tongue. The frog of a mule's foot, for example, they called the 'swallow' ( $\left.\chi \varepsilon \lambda \iota \delta o^{\prime} \nu a\right)$, the word used in ancient times for the hollow of a horse's foet, because it was forked like a swallow's tail. Furthermore, $\zeta \varepsilon v \gamma \lambda \eta$ is not the usual word for the yoke of an ox in other parts of modern Greece, and $\mu$ spoútas for 'birds' is excessively curious, a word anciently used to denote being gifted with the power of articulation. It is in pastoral life that words still linger which are forgotten in aught but the pages of Liddell and Scott.

After a ride of four hours we came to our destination, a long strip of marble which runs into the sea like a bird's beak, and shelters a little bay from the fury of the 
north wind; it is almost at the extreme northern point of the island, and was in ages long gone by a favourite resort of mariners during stormy weather. This tongue of marble is in three places covered with very neatly cut inscriptions placed on flat spaces of marble which slope down to the water's edge. Some of them are very old, but most date from the Roman and Byzantine epochs; for the most part they are prayers for good voyages, and thanksgivings for safety made by those anchoring in this little bay in time of tempest, both for themselves and their friends. These writings on rocks are found in many parts of Greece; in Santorin of Mesa Bounò I saw lots of them, and likewise I hear they are common on the mainland. Those at Syra are interesting from their diversity.

Taking the pagan ones first, we find most of them to be simply names. Mithres of Sardis is the only one which conveyed anything to our minds, for Mithres is a name found on Sardian coins. Again we have the names of those who used this tongue of land as a point

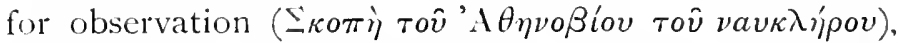
and various others, reminding us of the passage in Lucian which says, 'It is necessary first before sailing to go to some point to observe if the wind is favourable.' Then again we have epigraphs in memory of friends, perhaps those who had been lost at sea; prayers for good voyages for the writers and their friends; thanks for prescrvation from shipwreck, principally to Asclepius; for example, 'We in the Milesian ship, thank Asclepius ;' and lastly, farewells to friends.

Many of these epigraphs refer to a temple of Serapis, which must have stood on this point, though all traces of it have been obliterated. Doubtless here many a hecatomb has been offered to propitiate this god, that 
he might send a favourable wind. Our herdsmen told us that quantities of coins were dug up here, and forthwith proceeded to dig. In a few minutes they produced some small defaced copper coins of no value, which they grave us. We next turned to consider the Christian writings, which are more minute in their information about men and ships, and are written in debased Roman characters, like those in use in the Byzantine school. and such as we see in use on the outside of Byzantine churches. Most of them begin with 'Lord help us! Lord save us!' \&c., and then give the name of the supplicant, his father's name, his country, sometimes that of his ship, and occasionally, though rarely, they mention the month and year. There are about roo of these, affording a curious collection of names, occupations, and countries ; sailors, captains, one novitiate, deacons, a soldier, a centarch, Commander Stephen, chiliarch of Asia with his aurarii, fellow-citizens, \&c., showing what a popular place of resort once was Grammata Bay, now lost almost to the world, for hardly anyone in Syra has heard of it, and if he had heard of it would never think of riding four hours to see such a sight. After a hurried lunch among the epigrams, we started on our weary way back across the mountains, returning, as our herdsmen affirmed, by a somewhat shorter way close to a church called Syringa, where is a fountain of healing water which is bottled and sent abroad. A popular distich of Syra, which our companions sang, tells us that for health all that is required is some water from Syringa, grapes from Chryse, and a sprig of basil from Cyparyssa.' Chryse and Talanta certainly seem at present to be the only places on the island where grapes will grow, and this with difficulty. Doubtless this distich is of a not very modern date, and may refer to the 
ancient fertility. As for the basil from Cyparyssa, I never saw any; but I have frequently realised how much prized the basil is in Greece for its mystic properties. 'The herb which they say grew on Christ's grave is almost worshipped in the Eastern Church. On St. Basil's Day women take sprigs of this plant to be blessed in church. On returning home they cast some on the floor of the house, to secure luck for the ensuing year. They eat a little with their household, and no sickness, they maintain, will attack them for a year. Another bit they put into their cupboard, and firmly believe that their embroideries and silken raiment will be free from the visitation of rats, mice, and moths for the same period.

Busy, populous Hermoupolis seemed horribly worldly after this wild ride. During our rambles in the Cyclades we visited it many times, and were always glad to get out of it, savouring as it did too much of this busy age. 


\section{CHAPTER XIV.}

NAXOS.

\section{An Hisiorical Sketch.}

From many points of view Naxos may be considered as the most important of the Cyclades. It is the largest, it is the most beautiful- quite equal to Corfù and the other Ionian islands as far as this is concerned; it is by far the most fertile; it has a definite mediæval history ; and up in its lofty mountains it contains some of the most primitive inhabitants of modern Hellas, half-robbers, almost heathens in their beliefs.

The town life of Naxos is utterly different from the mountain life. Half of the inhabitants of the town are Roman Catholics, relics of the time when Naxos was the centre of an island duchy under the protection of Venice, and a bulwark against Islamism ; but on the benighted peasantry of the mountains the passing waves of Latins and Turks have not had the remotest influence. In many respects it would appear that the Greek influence on Venice was considerably greater than the Venetian influence on Greece. All the names of officers in the Venetian republic were borrowed from the Byzantine Empire, the syndic, the signori di notte ( $\nu$

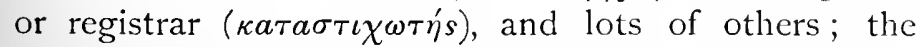
names of boats, the sandolo ( $\sigma a \nu \delta a ́ \lambda \iota o v)$, so called from 
its likeness to a shoe, the scafo, the ippagogo, the gondola, and others; and when in I049 a Venetian doge married a Greek of the house of Ducas, she brought with her all the Byzantine refinements, amongst others the use of the fork, which in the Venetian dialect is still called a 'piron,' from the Greck ( $\pi \eta p o \hat{v} \nu \iota)$, instead of forchetta.

To day Naxos is entirely eclipsed by Syra, the capital of the Cyclades. Santorin is a far more flourishing centre of trade; the fertility of the soil has been the bane of the Naxiotes, and has made them the idlest vagabonds in the Cyclades.

Before landing at Naxia, as they call the capital, let us take a hurried glance at the history of the Latin dukes; it will enable us better to understand the people we are going to sojourn amongst. Our authorities for the history of the two lines of sovereigns who occupied the duchy of Naxos for 300 years are meagre, but they are twofold. They are from the compilations of a Jesuit and a German, the Abbs Sauger and Von Hopf. The latter styles the compilation of the former 'a romance full of Jesuitical legends, and untrustworthy,' and to prove this statement he treats us to the most complicated disquisition on intermarriages, feuds, and contested successions which it ever was the lot of any historical student to wade through; but in broad lines our authorities agree, and surely the broad lines are all that the most ambitious could care to know about the dukes of Naxos and their appanages, the lords of Melos, the archons of Santorin, the proveditori of Tenos, who intermarried, squabbled, and fell, in the course of events, into the gulf of Islamism.

Everything tends to prove, especially the rancour of the Jesuit, that during this period there was no love lost 
between Greek and Latin, and that the Latins only carried their influence to the coast towns, and that when the Latin power was over the orthodox religion at once re-established its power. The whole of this influence was due in the first instance to the Latin conquest of Constantinople, when Venice found herself the mistress of millions of subjects with whom she had not the slightest idea what to do. Consequently the Queen of the Adriatic accorded to her citizens the power to conquer for themselves any islands they had a fancy for, on condition that they would hold them as fiefs of the Republic. This was a new opening to ambition, a stimulus to privateering life on a large scale, giving birth to such men as after centuries saw in the persons of Sir Francis Drake or Raleigh.

One of these privateers was called Marco Sanudo, of a rich and noble house, whose ambition soarcd high, for he wished to become lord of Crete; but being unable to do this, he laid siege to Naxos, where the pusillanimous Greeks soon gave way, and this he made the headquarters of his new principality; he built a strong castle with twelve towers thereon, and established a dynasty, which was recognised by the German emperor, Henry IV., as the duchy of the Egean Sea. Other Venetian nobles and merchants, the Ghisi, the Giustiniani, \&c. followed this example, and hazarded their riches in their lust for principalities, however small : so Greece, as well on the mainland as amongst the islands, was covered with Latin settlers.

The pet object of the Sanudo family was to reign in Crete, and though they gathered to themselves the islands around Naxos, yet they never lost sight of the main object of their ambition.

The third duke, another Marco, tried to conquer 
Crete with no better success. During his reign the Abbé Sauger gives us a side glance at the feeling which cxisted between Greeks and Latins. 'Disturbances,' he says, 'took place, owing to the idolatry of the inhabitants, who set up an altar to one called St. Pachys, and mothers made their children pass through a hole, and thought they would grow fat ( $\pi a \chi^{u} s$ ) by this.' Now this is just the sort of thing they still do, and even worse, as we saw at Melos, ${ }^{1}$ so I am inclined to believe what Abbé Sauger tells us, and from this we can infer that religious rancour kept the Greeks and Latins from amalgamating.

The early dukes of the house of Sanudo made Naxos and the other subject isles so strong that the emperors of the Paleologus line failed to recover the islands, though in 1272 the Greek fleet managed very nearly to win them back, and would have done so had not a Venetian general, who lies buricd at Venice with the following epitaph, 'Terror Grecornm jacet hic,' come to the assistance of the duke. And in the days of these earlier dukes sprang up all those fortress towns, one or two of which we visited in every island; by degrees even the fealty due to the mother country began to be laughed at, until rumours of Turkish encroachments began to alarm Europe, and the dukes of the house of Sanudo had to turn crusaders against their will.

The eighth duke of Naxos, the last of the Sanudo line, was nicknamed Spezzabunda, and his renown as a valiant chief struck terror into the Turks, who no longer ventured to leave their safe harbours in Asia Minor. There is a rhyming legend still sung in Naxos, which tells us how he ended his days in I 345 , surrounded by ten Turkish galleys, and seeing his own sinking, he 1 vide p. 64. 
cast himself fearlessly amongst them and wrought terrible carnage before he was killed. Marino Sanudo of Venice, in his notes, gives us an account of this kinsman of his, and says he was one of the most courageous and intrepid heroes of his day.

Then the children of two daughters of the house of Sanudo, the Crispi and the Carcere, fought for the succession; the former killed the latter by treachery and established a long line of dukes, the descendants of whom, bearing the name and arms, two upright swords between two lozenges, still live in Paros.

The history of the Crispi dukes of Naxos is a wretched one. The Egean Sea was a perfect hotbed of contention: the archons of Andros carried on a private war with the archons of Santorin, the dukes of Naxos carried on a war with the Turks on the one hand and their great rivals the Ghisi, lords of Tenos, Mykonos, Keos, and Seriphos, on the other. Venice interfered; she sent proveditori to some islands, rectors to others, whilst some she let out to the highest bidder, so that the resources of the island were drained to the last dregs. No wonder the Cyclades suffered terribly under the Latin rule, far worse than ever they did in after years under the Turks.

Every year the Turks grew nearer, and Christian disasters crowded one on the other. We read of Francis Crispi, the nineteenth duke, entering upon terms with the Turks in I 504 with the full sanction of Venice. His son John, the twentieth duke, gave up the keys of Naxos and much money to Barbarossa, who sacked his castle, but left him in possession of his duchy on his promising to pay a tribute. Poor duke John was so humbled at this that he wrote an apologetic letter to Pope Paul III. and the Christian princes, saying,-- 
'I have covenanted to pay yearly 5,000 gold pieces, and even this, in the eyes of my burghers, is too large a sum for the poor duke of a mean principality, yet I shall conscientiously pay it.'

Under James Crispi, the twenty-first and last duke of Naxos, the duchy was in a woeful state; he had no money and no ships, his subjects refused to pay taxes : he was himself a good-for-nothing fellow, who made of Naxos what it was in ancient times-nothing but a temple of Dionysos, drinking and gambling with his Venetian courtiers. So the good people of Naxos resolved to stand this no longer, and sent secret envoys to the Porte, volunteering to give themselves up, reserving one or two rights for themselves, such as having the power of ringing church bells and of repairing their sacred edifices.

James Crispi heard of this too late; his envoys were put in prison by Selim II., and so was he, and not released for some years, when he retired to Venice, and was received with ovations and given a pension, and with him the duchy of Naxos ceased to exist.

The Sultan Selim II. then made a present of the revenues of the duchy to a Jew, whose name has been handed down to us as Joseph Nacy, or Nassi, or di Nasi, probably of Naxos. He was court Jew to the Porte, Selim's favourite, and known by the name of 'the rich' or 'the great' Jew. He was a creditor of the King of France, he had ships of his own all over the Mediterranean, and was in the same position as the Fuggers of Augsburg were to Charles V., or the Rothschilds of this century.

It may be imagined that the Naxiotes were aghast when they heard that they were to be ruled by a Jew, for a Greek hates a Jew more than he can express, and they 
repented of having deposed the Crispi and longed for them back. Wisely the great Jew Joseph did not venture to Naxos, but sent thither a Spaniard, Francis Coronelli, as his agent. Coronelli was a worthy man, no duke was ever beloved as he was, and by wise measures he sought to rectify the errors of the Duke James. Coronelli's son married a niece of the last Crispi and took her name, and it is through this line that the Crispi, who now own so much land in Paros, are descended, the last relics of a bygone dynasty.

When the great Jew died the Sultan took back the fief he had given, and henceforward ruled the Cyclades through his agas and dragomans. Only once again, in 165I, when the Venetians gained a great naval battle off Paros under a Mocenigo, was there ever any prospect of the Naxiote duchy being revived.

After the extinction of the Latin line, the Latin nobles, however, continued to occupy the highest position in the islands; most of the fertile land belonged to them ; even to this day they still bear the title of baronakki (little barons), the old coats-of-arms are over the doors, but they have always been detested by the Greeks, and now that the Greek element is dominant they are fast decaying. Tournefort, in I700, describes their animosity thus naïvely, 'If a Latin stirs the Greeks tell the kadi of it, and if a Greek opens his mouth the kadi knows what he has said before he shuts it,' and the Latins had to get a special dispensation from Rome for marrying their cousins, to avoid intermarrying with the Greeks, so great was the hatred of their rivals.

The Roman Catholics still live in the upper town of Naxos, around the ruins of the old castle. The Le Lasticqs, the Barozzi, the Frankopouli have most of them finc houses, with the remains of Venetian greatness about 
them, but they are all wretchedly poor. In the war of independence they sided with the Turks, and consequently they are now suffering for their folly; inch by inch the land is passing out of their hands into those of the Greelss.

\section{The Town of Naxia.}

It was the intention of spending Christmas, and taking a good rest, that caused us to make for Naxos. Somehow or another we promised curselves greater comforts there than elsewhere ; the name and the knowledge of what it once had been probably gave cause to this hope, which was doomed to disappointment. Nowhere in the Cyclades had we greater difficulty in getting a suitable lodging than in Naxia; we were shown to what they called an inn, a large room without glass in the windows, and no furniture except wooden tressels for beds, evidently the abode of sailors when forced by bad luck to wait in Naxos. Then we went to the demarch, who received us courteously, but with small hope of success. Eventually we were deposited in a house by the sea, belonging to the agent of the Greek steamer, and as long as the weather was fine it was a charming abode. We had the use of two rooms: a sitting-room with a balcony overlooking the sea and a lapageria trained over the walls inside as if for our special Christmas decoration, and a bedroom, the only drawback to which was that it was entered by a trap-door at moments when visitors were least welcome.

Our host had been a sea-captain, and had two pretty daughters, who waited upon us, cooked for us, and sang nautical songs to us in the evening, and the first day after our arrial, Christmas Eve, on which the 
sun shone as hot as in July at home, we were contentment itself. It was too hot to walk, so we got a boat, and rowed to the little island on which stands all that is left of what tradition calls the temple of Dionysos: the people call it the palace of the king of Naxos, and the

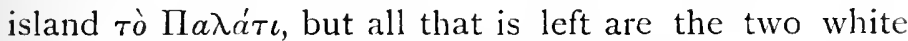
marble doorposts and the lintel, standing up high and solitary on the summit of the little green island, a conspicuous object from everywhere. Formerly this island was joined to the mainland by a pier, large blocks of which are still to be seen in the sea. A few years ago Dr. Kallivoutzi made an excavation here, not, however, with very satisfactory results, except that the form of the temple and several of the drums of its pillars have been laid bare ; from the pier there evidently were steps leading up to it, and it had doubtless a propylcem facing the mainland.

On Christmas Eve this little island was delicious, brilliantly green with a small shamrock and a primula all over it; a real emerald isle set in the bluest of seas. We determined to eat our Christmas dinner on it if the morrow was as fine, for the view orer Naxia and the mountains was enchanting. Naxia resembles in many ways an Italian village on the Riviera; there is the Sanudo's castle crowning the height, there are the peaky blue mountains in the background taking every possible fantastic shape, there are the rows of aloes and the rocky coastline. The harbour is small and wretched, having in the centre of it a tiny church, three yards by two, built on a rock, and dedicated to the Virgin of the Harbour, to which boats are moored. All round the coast there is not a decent harbour in Naxos, and though the island is rich in corn, wine, einery, and marble, yet in a harbourless mass of mountains progress is impossible. During a storm whilst 
we were there, a cailque anchored in the harbour about fifty yards from the shore, and freighted with coffee, sugar, and other groceries, ready for disembarkation, was capsized before our eyes and the contents lost.

The lower part of the town is all Greek, and contains the metropolitan and other churches; here every house is inhabited by Greeks, for it is only up on the hill, where is still a Capuchin convent close to the fortress, that the Latins live.

As we sat on this island rock we could not help wondering if this really was the scene of the old worship of Dionysos at Naxos ; even now there are many traces left in Naxos which point to this worship. St. Dionysius, the Christian successor of the ancient wine god, is greatly worshipped here, and about him a curious legend ${ }^{1}$ is still told, clearly pointing to ancient cult; it runs as follows. St. Dionysius was on a journey from the monastery on Mount Olympos to Naxos ; as he sat down to rest he saw a pretty plant, which he desired to take, and to protect it from being withered by the sun he put it into the bone of a bird. He went on and was surprised to find that it had sprouted before his next halt, so he put it, bone and all, into the bone of a lion; again the same phenomenon occurred, so he put his treasure into the leg bone of an ass. On reaching Naxos he found the plant so rooted in the bones that he planted them all; and from this up came a vine, with the fruit of which St. Dionysius made the first wine. When he had drunk a little of it he sang like a bird, when he had drunk more he felt as strong as a lion, and when he had drunk too much he became as foolish as an ass. The gods of old have been turned into modern saints, sometimes even regardless of sex, as we shall see at Keos, where ' Von Ifahn's Greek Legends. 
the male, St. Artemidos, represents the female, Artemis. Demeter, in the present order of things, is also rcpresented by a man, St. Demetrius, who in certain places is the special protector of flocks, herds, and husbandmen, and in this capacity is called 'of the dry land' ( $\Sigma_{\text {Tepravos), as }}$ opposed to St. Nicholas, the saint of the sea.

Place names in Naxos still recall the old Bacchic worship. One of the loftiest mountains of the island is called Mount Koronon, reminding us of the nymph Koronis and the infancy of Dionysos. Just over the town is a fountain called by the natives the tomb or baths of Ariadne: here in $182 \mathrm{I}$ an old man told me that the Turkish dragoman had made extensive excavations and took with him quantities of inscriptions to Constantinople, leaving only one behind him, which forms now the step of a house, and which tells us that it was once a tablet in the Prytaneum of Naxos.

That afternoon, on returning from the island rock, we saw the weekly steamer arrive in glorious, calm evening light. This event is a great excitement for the Naxiotes, and the names of happy recipients of letters are publicly called out; so we retired to rest on Christmas Eve, little dreaming what a store of storm and rain was being prepared for us by Jupiter the Rainy. For nearly a week Naxos and her mountains formed the centre of a sort of cyclone ; torrents would fall for hours, and then a gleam of sunshine lead us to hope that it was past, but it returned again with equal vigour, going round and round the lofty mountains. In our house we suffered severely; the miserable flat roofs covered with pressed mud soon began to leak; our sitting room was a lake, and then it came into our bedroom, so that we were forced to sleep under umbrellas and waterproofs. Never was the intense idleness and apathy of the Naxiotes more 
apparent than during this weather. No mules came in from the country villages, for nobody thinks of travelling when it rains; consequently no brushwood was brought in, and the stock of fuel was soon exhausted, the result being that there was not a fire in Naxia at which to cook a meal-not that this mattered much, for there was nothing to cook. For once in our lives we were compelled to decide that we would keep our Christmas like the Naxiotes, according to old style, and fast whilst those at home were feasting.

Men stay in bed all day on these occasions, murmuring, 'Winter, winter!' when my thermometer outside our window never fell lower than $55^{\circ} \mathrm{Fahr}$. It was the misery of damp and inactivity from which we suffered, during those weary days, not from cold ; and in those wretched pasteboard houses, where rain pours in from window and from roof, we could get no definite rest. A good winter's storm in a northern clime would be sufficient to efface from memory the dwellings of the Greeks of to-day.

Our only amusement during these days was paying visits and making ourselves at home with the Naxiotes, all their sitting-rooms being flooded like our own. We visited most of the Latin families on the hill, and saw their treasures of embroidery and jewellery preserved since the Venetian days. We visited the Capuchin convent, which looked thoroughly Italian, and the superior conversed in Italian; and then we visited the Greeks below, of whom none left a plcasanter impression upon us than Gregorios, Bishop of Naxos and Paros, called the despot ( $\delta \varepsilon s \pi o ́ t \eta s)$.

$\mathrm{Hc}$ is a comparatively young man, and took a special delight in showing us his sacerdotal treasures, for we could not help audibly admiring the jewel which he wore-an 
enamelled representation of the Resurrection set in diamonds - so forthwith he rang for his mitre, a round pearshaped thing set in a crown, with the eagle, the symbol of Constantine, on the top. He explained to us how the Patriarch Gennadius, when Constantinople was taken by the Turks, had saved the crown of Constantine, and that during one of the liturgies he came forward to console the Christians, telling them not to grieve for the loss of their emperor, for the crown was saved, which the Church was to preserve until the kingdom was restored; so all Greek mitres are set in a crown. Bishop Gregorios' mitre was a handsome one, adorned with an abundance of uncut emeralds, sapphires, rubies, and diamonds on a smooth velvet foundation; and a diamond cross at the top, all imitation, alas! but splendid to look upon.

So gratified did we seem at this opportunity of closely examining the details of a Greck bishop's robes that he sent for the rest and put them on for us. There is much that is symbolical in the dress: at the bottom of

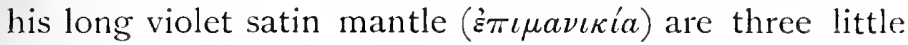
silver sheep-bells, indicating his pastoral office; there are bands of red and white to symbolise the rivers of grace which are supposed to flow from the bishop's mouth; on the corners and at the shoulders are pieces of white brocade with flowers on it, and trimmed with gold braid - this is the $\dot{\varepsilon} \pi$ iyovátıov, and is supposed to represent the towel with which Christ girded Himself at the last supper; and then on the back are the four gammas, back to back, so arranged as to form a Greek cross. Bishop Gregorios showed us two very handsome pastoral staves, one of ivory and tortoiseshell, and the other of silver gilt; dressed in his robes, and with a staff in his hand, he had had his photograph taken, a copy of which he gave us with great pride. 
Perhaps the greatest relief to the monotony of our days in Naxia was afforded by the cheerful evenings when the daughters of our host sang to us. Their voices were always pitched in what to us sounded a high and unnatural key; but they sang their parts well, and with great feeling, especially 'The Mariner's Love Song,' of which I here append as literal a translation as possible, for it illustrates the simple figurative language in which a Greek loves to indulge :-

In a tiny little caïque,

Forth in my folly one night,

To the sea of love I gat me,

Where the land was nowhere in sight.

O my star! O my brilliant star !

Have pity on my youth;

Desert me not, oh, leave me not

Alone in the sea of love!

O my star! O my brilliant star !

I have met you on my path.

Do you bid me not tarry near you?

Are your feelings not of love?

Lo, suddenly about me fell

The darkness of that night,

And the sea rolled in mountains around me,

And the land was nowhere in sight.

The Greck Christmas day immediately followed our return from the mountains of Naxos, and we enjoyed it considerably more than our own. A Greek Christmas in its ceremonial closely resembles one of ours.

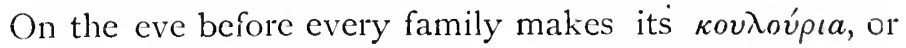
round cakes twisted like a serpent, into one of which perhaps a coin is put, and the one who finds the coin is like the individual who finds the ring in our plum-pudding. Children go round from house to house singing mournful 
dirges about Christ's birth, for which they receive gifts from the householders; and on Christmas Day, after the liturgy, the priest goes from house to house with his acolytes and blesses the inmates with his censer.

It is a general holiday, and people in their best clothes visit their friends, and are given sweets, coffee, and raki, and in the evening they dance and imbibe far more than is good for them.

To get away from the constant succession of curious visitors who pestered us on Christmas afternoon we walked up the hillside behind Naxos to visit a nunnery dedicated to St. Chrysostom, into which we were told no males would be admitted without special permission from the bishop. On reaching it we entered a low door without opposition and climbed a ladder which conducted us to a storey of empty cells; it seemed like a charmed palace, this huge empty nunnery, as if inhabited by some spellbound princess. On our descent, however, we came across and terrified three nuns just coming out of their cells, whose surprise may be imagined at seeing two fair-haired males descending a ladder and introducing themselves as ' angels,' that is to say, "A $\gamma \gamma \lambda$ io , or Englishmen, on Christmas Day. For some time the ignorant old things were too bewildered to speak, and it was long before we could make them understand who we were, and what our object was in thus intruding. Then they took us to their church and showed us their treasures; they gave us coffee and sweets in their reception room; put questions to us of a character which made us almost laugh, such as, Where is England? Is it near Europe? Are the English Christians? and so forth. There are only five of them left now, and when these die the nunnery of St. Chrysostom will be closed-no loss to the world at large. 
The bishop was much surprised to hear we had paid the nuns a visit without his leave, but in no way annoyed, for he asked us to dinner next day if the steamer did not come ; but I regret to say that the steamer did come, and our dinner with the Bishop of Naxos was relegated to our category of disappointments.

\section{In the Mountains of Naxos.}

It was certainly not a fine day, properly so called, when we started for the mountains of Naxos, but we flattered ourselves that the force of the cyclone was over, and that we might go on our lengthy expedition without loss of time. Pictures of fearful torrents and drenching rains were drawn for us, but we were determined to go, thinking that nothing could be worse than sleeping under umbrellas in Naxia. Time, too, was flying rapidly, as quick almost as our patience; so at length we engaged a very brave muleteer with a large umbrella, whose courage put two others to shame, and our cavalcade was made up. It was easy work at first-along a new road which is in course of construction up the fertile plain behind the town-and as we rode along we realised how the change has come over the land; for mountains which once were covered with trees are now bare rocks, and the soil from these has been spread over this plain by torrential rains such as we had experienced for the last few days; and they told us that, in digging deep for water on this plain, evidences of former cultivation and relics of the past are frequently discovered several feet bclow the present surface.

Everything is very fertile here, the very place for the home of the wine god Bacchus; for Naxos, the Little 
Sicily, as the ancients called it, produced in its day a wine which Archilochus likened to the nectar of the gods; and even now they make a wine, which they have named $\tau \grave{o} \kappa \rho a \sigma \grave{\imath} \tau o \hat{v} \Delta \iota o \nu v ́ \sigma o v$ (the wine of Dionysos). Pindar calls it 'rich Naxos,' and it maintains the same character still; yet the labourers of this favoured isle are throughout the Cyclades noted for their want of industry, though they have hardly to turn the soil to ensure a rich harvest. The labourers of Naxos have a privilege which is elsewhere unknown: the employers of labour by custom give their men olive oil with which to make their bread more palatable, and it is a custom which the peasants imperiously claim as their right.

It was a relief to leave the plain, for the mule track was reduced to a muddy torrent-bed by the late rains, and as we ascended the hill we discovered that our muleteers intended to cheat us out of the beautiful villages of Potamia-Upper, Middle, and Lower Potamia -because they feared to cross a stream. The evening was lovely, so we refused to be cheated, and insisted on being conducted up the valley of Drymalià, greatly to their annoyance. We dismounted and started on foot ourselves, leaving our servant to bring on the muleteers as best he could. On our way we stopped at a lovely country house, which was now rather dilapidated, but bearing evidences of bygone wealth. It was quite like a villa in Tuscany, buried in olive and citron groves, and commanding a splendid view up the valley, with the lofty peak of Mount Jupiter for a background, and the rivers and craggy outline of the range which forms the backbone of Naxos. At the bottom of the garden was a little many-coloured ruined church, with its Byzantine dome and arched windows hidden away amongst figs and olives; the lapse of time had given it rich red and 
yellow streaks: it was a perfect gem for an artist. We were quite enchanted with this villa and its surroundings, the rain-drops on the olive trees sparkled like jewels in the bright evening light, and the tall brown reeds waved gracefully over the pond before the gentle breeze. In summer time a retreat like this, when the dust and heat of Athens parches everything that lives, would be a paradise.

The three villages of Potamia climb up the hillside from a river, which gives them their name, and which certainly did not warrant our muleteers' desire to avoid it. It was really ridiculous to see these great, strong men standing on the brink of the stream, which at most would not take them above their knees, and saying that they feared to take cold. At length one of them, braver than the others, took off his shoes and stockings and led the mules across until we were all high and dry on the other side, and soon we found ourselves halting for the night in the village of Mesopotamia.

Everything around was luxuriantly fertile ; maidenhair, Cretan moss, and wild flowers innumerable lined the path, though it was but a few days after Christmas; and orange and citron orchards, heavy with fruit, covered the slopes; above these towered in sombre dignity a few tall fir-trees and cypressès, up the stems of which the vines are trained, like ivy in Ireland. Rocks of fantastic shapes mingled with the verdure, and behind the three villages rose a deserted fortress of mediæval times. By the side of our rocky path an angry stream bounded, and now and again the path itself was turned into a watercourse, up which the mules had much difficulty in making their way. Certainly these 'river villages' were seen to the greatest advantage when approached, as was now the case, by a cataract. 
We came to a halt at a dirty house, where we had to sit for hours, whilst a palace, they said, was being prepared for our reception, and where lots of people came in to see us, unpleasant, rascally-looking people, of a different type to any we had as yet seen in the Cyclades. They constantly plied us with coffce, raki, and sweets as we waited for the hen we had purchased to be boiled, and they played persistently for our benefit on the syravlion, or panpipe, and the drum. When shepherds play the panpipe on the hillside it is romantic enough : the instrument is a simple one, just two reeds hollowed out and placed side by side in a larger reed; straws run up the smaller reeds, and there are the necessary blowholes: but in a tiny cottage the shrill sound of the syravlion accompanied by a drum almost drove us wild, tired and hungry as we were, so we had to pretend to headaches and ask for repose.

Our palace was at length ready: it was the summer residence of a Greek from the town, who had left the key in charge of the village blacksmith, and in summer, I dare say, it might be a charming residence, with its hanging gardens and balconies covered with creepers and vines; but then there was not a pane of glass in the whole house, nothing but ill-fitting shutters to keep out the rain and wind. A bed was rigged up for us, in a storeroom full of oranges, by placing a mattress on some boards, which mattress felt as if it had been made of walnuts; and the rain poured in from the roof, so that our waterproofs and umbrellas were again in requisition. Next morning it rained again, but not too heavily to prevent our climbing up to the medixval camp above Upper Potamia.

This fortress, which commands the two fertile valley's of Drymalia and Trajaia, is built on a rocky eminence, 
which has evidently served a similar purpose for centuries, and is, in fact, the acropolis of the Naxiote valleys. There are remains of an old Hellenic wall upon it, of which I could only trace about twenty feet, but by far the greater part of the buildings are of the Venetian epoch, and point to its having been a stronghold of the Sanudo family. Just below the summit is a hot spring in a field; this, the peasant who acted as our guide told us, was once the bath of the queen of the ancient Greeks. 'What was her name?' I asked, hoping to find some trace of the legend of Ariadne. 'I don't know,' was the reply, 'but my uncle, the schoolmaster, does.' On returning to Mesopotamia I sought out the old man, and he was very positive that the queen's name was Aphaidra ; which disappointed me and gave me no clue whatsoever as to the origin of the tradition.

Close to this spot a labouring man found a jar of Byzantine coins, and in connection with a church at the top of the rock a tradition exists, which excites the Potamiotes immensely whenever they think of itnamely, that a pirate some years ago killed the priest of this church, because he refused to tell him where he had buried his treasures. Periodically the peasants have a fit of digging for this hidden treasure, for it is known that during the war of independence everyone buried everything he had that was valuable, and the occasional discovery of some of these things, the owners of which have died and left no cluc behind, tends to keep up the excitement. Hiding money in the ground was the favourite bank of rich men of business in ancient days, as we learn from the plea urged by the guardians of the younger Demosthenes, to account for the non-production of money bequeathed by the elder. 
From the summit of this old camp we had a most repaying view over the two valleys. Trajaia is a lovely spot, with seven prosperous villages, nestling under the shadow of Mount Jupiter, and covered with olive trees. From here only distant glimpses of the sea can be got. It seemed by far the most inland spot we had yet visited in the Cyclades.

The people of Potamia are most superstitious about this ancient camp, and believe it to be the haunt of uncanny animals. One day our guide, Maratris by name, said he was out shooting hares, when he saw a lamb rolling down the hill and making a noise as if it was pulling a chain after it; on approaching the lamb took the form of an ox. Another time he saw phantasms in the shape of sows rushing wildly down the hill and disappearing in a swamp. It appeared that many similar stories are attached to this spot, about bears and other savage animals having been seen thereon, and terrifying the inhabitants, who would not for worlds pass the night near it, and invest it with all sorts of horrors.

We did not like the Potamiotes at all, for, in spite of all their protestations of hospitality, their demands for payment were atrociously exorbitant; that afternoon before starting we had an exciting scene, and only by threatening to return to Naxia, and have the extortioners put in prison, could we get away; it was positively the only place during our island wanderings where we had any difficulty of this kind.

The afternoon was again lovely after the morning rain, and the gigantic olive trees in the vale of Trajaia were sparkling in the sunshine. In this valley, too, there are evident traces of ancient occupation, and it is supposed to take its name from Apollo Trajios, who was worshipped here. Chalki is the chief town of the 
district, and in the house of Gabalas, of Chalki, we took up our abode. Gabalas was a man of exceedingly jovial tendency, and on the refusal of our muleteers to accompany us further he volunteered his services in getting together another team for us, of which he was to be the leader. He came from Crete, he said, when quite young, and was ready to go back there again as soon as the Turks had left it; meanwhile he managed, with his wife and son, to get along pretty well at Chalki. Not that his house was by any means a paradise, for under his only bed, which was given up to us, they kept a perfect menagerie of cocks, and hens, and lambs, which sent up by no means a savoury odnur to our nostrils; but they were afraid of leaving them out of doors for fear of the robbers of Apeiranthos, and had nowhere better to put them. These robbers from the mountains seem to be the bane of the villages of Naxos.

Chalki seems to have been a place of considerable importance in medixval days, and the Church of St. John here is the oldest Christian building in the island : it is curious in formation, with a long porch with three Gothic arches on either side, about fifty feet long, and having no roof to it now, but a vine trailing over it: this seems to be a mediaval addition. Inside the building is strictly Byzantine: you enter a narrow narthex with arches on either side, which lead into two dark collateral chapels; between the narthex and the choir is a narrow space with a waggon roof; over the choir is a dome covered with frescoes. The front of this church has a stepped edging.

All around Chalki are ruins of churches, dating from the middle ages, hidden away and buried in the olive groves; one of them, dedicated to St. George, is especially picturesque, being covered with ivy, and over the 
archway into the nave is a very long old Hellenic inscription; also there are several traces of an ancient temple - perhaps that of Apollo Trajios. But these churches are now for the most part disused and falling into ruins, as also are the large towers, where once lived the Venetian proprietors around Chalki. It is a place of the past, but very lovely in its decay.

Gabalas treated us to his best fare. In addition to the usual fowl, we had a pilaff of snails; that is to say, snails boiled with rice and oil, which formed a most excellent dish. Our host revelled in them, and as he busily extricated them with a pin from their shells he propounded to us a Naxiote riddle, at which he laughed a great deal, and was surprised at our guessing it quite easily :-

There was a thing - such a wonderful sight--

Two horns on its head, animal it was not ;

Such a wonderful thing-such a wonderful sight--

It carried a saddle, and mule it was not?

Gabalas was full of life as he accompanied us on our road towards Philoti on the morrow; this is the last village in the vale of Trajaia, and just under Mount Jupiter ; and here we were given a large Venetian tower all to ourselves with a commanding view, the lower storey of which was a pigsty, the top storey a dovecote, and in the room next to ours we were alarmed by strange noises in the night, and on looking in we found two sheep put there for safety. But the rain did not penetrate through the dovecote, and we were thankful to be once more dry; also they gave us a large brazier full of charcoal, with which we were tolerably successful in drying our clothes. Our prospects of food, too, were good, for we met a man with his pockets full of woodcock and partridges, all of which we bought at the rate 
of sixpence a piece, and could not be got to feel that we had becn greatly cheated when Papa Eleutherios, a priest who took us under his special care, told us we had paid twice too much. Papa Eleutherios installed himself in our tower as head cook; he took off his cassock, and forthwith set to work to pluck our treasures: he was the pattern of good-nature, and rushed all over Philoti in search of comforts for us, and refused to allow us to buy loaves at a drachma apiece. 'Far too dear!' he said, and he ran off to get us some of the sacred bread (äpros) which is presented by the faithful to the priest. (This word äpros, by the way, is one of the many instances of the preservation of an old word through Church influence, $\psi \omega \mu i$ being the common word for bread.)

After our meal the priest came out with us to show us the lions. Philoti is a large village, crowning twin heights, with an ugly new Greek church in the declivity between. As we were climbing up one of the heights we heard terrible language issuing from a shed where some women were grinding corn with simple but quaint handmills, namely, two heavy round stones, the upper one of which works on a pivot attached to a stick a yard and a half long, which is fixed into a wooden fork in the wall so loosely that it can be revolved with ease by pressing on the stick.

The women had stopped their grinding, and were listening with awe to the declamations of an old greyhaired hag, who was telling a pitiful tale of how robbers from Apeiranthos the night before had broken into her yard and tried to steal her pigs, which squeaked so loudly that she woke, and frightened the robbers away, but not before one of her pigs had been slain. Nothing would satisfy the old woman but that we should return with her to her house, view the scene of the intended robbery; 
and lay her case before the authorities on our return to the capital.

Everywhere in Naxos they have a bad word for the people of Apeiranthos ; a village of robbers, we were told it was, away in the mountains. It was to be our next halting place after leaving Philoti, so we were concerned at all the evil reports we had heard ; for, say they, a man of Apciranthos is clever enough to steal the sole off your boot, or the hat off your head, without your knowing it; and the facetious Naxiotes tell an ill-natured legend about these people with great gusto, namely, that Apeiranthos was a Cretan colony ; that Barabbas was a Cretan; and that after his delivery from prison he returned home, where he behaved so badly that the Cretans drove him away: so he came to Naxos and founded the colony of Apeiranthos.

By the time we got to the old woman's house we were almost out of breath, for she lived at the extreme summit of one of the heights in a funny desolate cottage, with furniture of a primitive kind, absolutely nothing worth stealing except her pig. However we saw here for the first time a speciality of Philoti, namely, a syphon with which wine is drawn out of the large jars in which they keep it. After the wine is put in they cover the jars over with a coating of clay into which a syphon is stuck, so constructed that you can fill it by suction; you then pour it out of the hole you have sucked and use the end that has been introduced into the jar for a handle.

The following morning (for a wonder!) was beautiful, and at earliest dawn the inhabitants of Philoti appeared on their flat roofs. I thought they must all be mad at first, for they were occupied in kicking about what appeared to me to be the marble pillars of some ancient temple; but I soon discovered that each roof was pro- 
vided with a round marble roller, and that every woman was kicking hers about to press the mud roof, which the late rains had disturbed.

To-day with a prospect of fine weather we determined to make the tour of Mount Jupiter-Mount Zia, as they call it now. Naxos in former ages was called Zia, and on a large stone on the northern slope of the mountain we rcad the following inscription in ancient characters: OPOE $\triangle I O \Sigma$ MIAHIIOT (the mountain of Milesian Jupiter). It is a peaked conical mountain, only 3,290 feet in height, but as it rises almost straight from the sea-level it appears exceedingly lofty. Its slopes are rugged and covered with the holly oak (Ilex aquifolium), with the prickly leaves of which the peasants feed their cattle. We first climbed up to a steep cave, which goes deep into the heart of the mountain : at its entrance is an altar called the 'church of Zia,' where a priest goes once a year in the summer time and holds a liturgy for the mountain shepherds; around it are a few incense pots and bits of wood which have been sacred pictures in days gone by. At this altar a shepherd is accustomed to swear to his innocence if another charges him with having stolen a sheep or a goat. An oath by the altar of Zia is held very sacred by the mountainecrs, and is an earnest of innocence. It is curious still to find the actual word Zzìs existing in this form, and the idea of is supreme God has been transferred from Zeus to the present religious tenets. 'God is shaking His hair,' say the peasants when there is an earthquake, as if He were the Olympus throned Zeus of the 'Iliad.' This care and mountain of Jupiter, I have little doubt, had much to do with the ancient worship of Jupiter. The old myth related how the king of the gods was brought from his bithplace in Crete to Naxos, where he was brought up, 
and from whence he removed to take up his kingdom on Olympus. We have seen the above-mentioned inscription, the cave with the altar still in it; is it not highly probable that this is the cave in which Zeus was supposed to have spent his youth? It runs a very long way into the rock, and we had it lighted up for us by brushwood, but it contains nothing remarkable, save a spring of hot water, which in ancient times may have given rise to superstition. A local tradition says that once upon a time all the inhabitants of Philoti took refuge here from Saracen marauders who followed them, and by making a fire at the mouth of the cave they suffocated them all.

Leaving the peaky summit of Mount Zia to our left for as midday came on clouds began to gather around the summit, and it was useless to make the ascent - we joined a path which leads from Philoti to Panormos, just close to a well of excellent water, shaded by a plantain tree, and called $\lambda \varepsilon v \gamma a \lambda \varepsilon$ sov, a word rare in later classical times, but used in the 'Odyssey' xvi. 273, and by Sophocles, where it is explained as meaning 'moist' or ' rainy.'

The tower 'of the winter torrent' (Xsipappos) is on this road to Panormos: it is round and of white marble, and is principally worthy of notice from its spiral staircase, but is in no way so perfect as those of Andros and Amorgos. Having seen this we returned by another road to Philoti, thus making the entire circuit of Mount Zia.

Next morning we started for that dreaded haunt of robbers, Apeiranthos. The road led over a spur of mountains which joins Mount Jupiter with Mount Koronon, and divides Naxos into two districts--the bright and sunny vales of Drymalia and Trajaia on one side, and the bleak northern villages of Apeiranthos, Komiakè, and Bothrò on the other. As we descended 
on the village Barabbas is supposed to have founded, we could not help thinking that, for nefarious purposes, he had chosen well, bcing, as it is, far off from the haunts of men, and overlooking from a rocky eminence a fairly fertilc valley, by which the sea could easily be approached.

We had a letter of introduction to the chief legal functionary of the place, the demarch, or, as our friend in Naxia said, 'the chief robber'; so we thought that we should at all events be in good quarters in this den of thieves. Whilst this lctter was being delivered we stood in the little agora with our eyes firmly fixed on our luggage. 'The reports are true,' we thought as we looked around us; for never have I secn a wilder, more forbidding set of people than the men of Apeiranthos as thcy gathered round and stared at us. The town is high, faces north, and is extremely cold ; so cach man had on a huge brown greatcoat, with hair outside and a rim of red inside; some had their hoods pulled over their heads; others had their cloaks hanging loosely around them, and showing a powerful physique. Altogether they resembled conspirators in a chorus, and made us regret having ventured amongst them. Another curious and marked type of these men was their large noses, which they screwed up when they laughed, and which incrcased their sinister appearance.

Our misgivings were soon dissipated by the kindness of the demarch and his brother, whose hospitality knew no bounds; yet we could not help noticing that the windows were closely barred, and that when they went out with us they gave special instructions to the women to look after our things.

'You sce,' said the demarch, 'there are some bad pcople amongst us, who live by piracy, though of late 
years their number has been greatly reduced. But it will be long before we lose the name of being the worst people in the island. Everywhere the Naxiotes have a bad name, and you have come amongst the worst of the Naxiotes.' He laughed at this confession, and I think we felt our confidence entirely restored by his frankness.

The Apeiranthiotes are thrifty and well-to-do ; they have comfortable houses, far better than the other Naxiote villagers. Many of them have made money abroad, and returned to spend it in their mountain home. They have quantities of lovely red silk $\mathrm{em}$ broidery amongst them, Cretan work, which points to their origin; for doubtless there is this much truth in the Barabbas story that Apeiranthos was colonised by Cretans at the time of one of the numerous revolutions which have driven away so many from there, and the ill-will, and perhaps jealousy, of their neighbours-for nowhere in the Cyclades are the Cretan refugees popular - have invented the tradition about Barabbas.

There is much that is quaint about this people: they speak a marked dialect, with ancient forms and words, which we met with nowhere else ; they use the ancient form of the plural, that is to say, they will say $\tau$ payov-

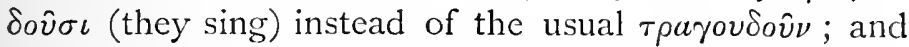
the shepherds of Apeiranthos wear a wonderful garb,

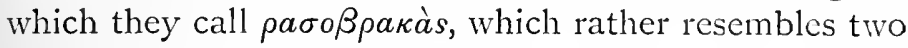
sacks of flannel fastened together than trousers; their shoes are sewn together with strings of goat's hide, round their waist they wear a cotton vest wound round and round their bodics, and skin caps on their heads.

In many of their houses we saw the lyre, the $\phi o ́ p \mu \iota y \xi$ of the ancients, still bearing its ancient name-a pretty little instrument, about half a yard long, of pear wood, 
such as they play, as a rule, at the village dances, which take place in the little square under the plantain tree. 'If you will only stay over Christmas you shall see one of our dances,' said the demarch; but even this did not tempt us to prolong our stay amongst the robbers. Inside the houses struck us as tidier than many we had seen: ornaments always adorned the best table-atrocious things, though they were from Europe-or gourds like cottage loaves, dried scarlet, with streaks of yellow and green : and our host gave us regular Russian tea out of a brass tea-urn, and other arrangements, which he had brought back with him from Russia. Nowhere in Naxos is embroidery so common as here : the beds are trimmed with it, the towels are smart enough for antimacassars: this gives an air of prosperity to the place and gratifies the cye.

Apeiranthos is a large village of romantic aspect, with houses built on the edges of precipices, and above it towers Mount Fanari, another peak of the Naxiote range. The houses are, for the most part, yellow with a peculiar lichen. The streets are tortuous and narrow, so constituted that when pirates came the inhabitants could baffle anyone who attempted to enter their labyrinths. As for hospitality these people are unequalled, and our host was desperately insulted at a hint of any remuneration for his kindness; as we rode away they filled our pockets with nuts and figs, and gave us a bottle of delicious raki to warm us on our road; and we wanted it, too, for about two hours after leaving A peiranthos our road ascended almost to the summit of Mount Fanari, where we were exposed to the hail and a biting wind, and were lost in mist. The Naxiote mountains in winter are anything but enjoyable-wild and desolate, with just a few eagles soaring in the air now and again ; 
rare birds in the islands though common enough on the mainland. Be careful when you see one to pass him on your right ; it is considered unlucky in Greece to see an eagle on your left. Presently we came to a particularly gusty spot. Gabalas informed us that this spot was called, as it justly deserved, 'the dancing place of the

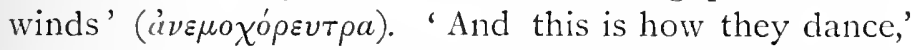
he said, as he went through some of the wild evolutions of the syrtos for our benefit, which has in it so much of the ancient Pyrrhic dance; and very funny he looked as he impersonated the antics of the winds in the mist on the mountain-top. The Greeks have still the same vivid imagination as of old, and love to personify the mysterious.

We left the village of Bothrò below us, close to which the emery mines of Naxos lie, and we reached Komiakè late in the afternoon. This is the highest village in the island, and for the two days we remained there we were perpetually in a mist. The village is only approached by roads which cross over the summit of the mountain; sometimes for a fortnight at a time no one can get to or from the village in the winter, owing to falls of snow. I must say I felt very uneasy all the time we were there lest this ill luck should befall us; a fortnight amongst the robbers would be preferable.

The only decent house in the village of Komiakè belongs to the demarch, Konstantinides, whom we had met in Naxia, and who had bid us stay at his house if we visited his village. He was away when we arrived, but his pretty daughter Athenà received us with the best possible grace, whilst we, with what seemed to us unparalleled effrontery, turned her father's house inside out. It is quite the fashion in Greece for travellers to act like young Marlow in 'She Stoops to Conquer,' only in this case you deliberately turn your host's house into an inn 
without the excuse of having mistaken it for one. We ordered our own meals; we sent for more ashes in the brazier whenever it got low ; our muleteers sat in a row in the parlour; and Gabalas, to our horror, treated Miss Athena in what we thought a horribly familiar manner. But there is no distinction of class in these parts, the dirtiest yokel who comes in is asked to sit down, and given a glass of raki, by the head lady of the place. Gabalas took off his boots and stockings in the drawing room to dry them at the brazier, otherwise, he said, he should catch a cold in his feet $\left(\pi o \delta a a^{\prime} \zeta \omega\right)$; and then in walked a miserable fever-stricken peasant to beg for quininc, shivering and wet through with the mist. He could not resist the sight of the warm brazier, so he drew up a chair and joined our circle, to the surprise of no one.

Komiake is but a miserable village of mountain shepherds: the houses are perfect hovels where the families live with their pigs, their cocks and hens, and their store of wood, whilst the baby's only cradle is the pig-trough. We went into many of them, and found their inhabitants truly primitive folk. Nowhere is the belief in Kalkagári more prevalent than here; evil spirits which appear on carth for ten days only in the year, from Christmas to Epiphany. An old hag we visited gave us a curious account of them. During these ten days these spirits dwell in caves, subsisting, like the Amazons of old, on snakes and lizards, and sometimes women for a treat if they can entrap them; at night they dance till cockcrow, and enter houses by the chimneys. So a careful housewife is bound during this time to keep embers smouldering all night on her hearth, otherwise the Kalkagári will get in and spoil all the things in the house with their dirty tricks. The priests only have the power of driving them away by blessing the houses as they do on Christmas 
Day, and then when Epiphany comes these creatures are forced to flee underground, taking before they go a hack at the tree which supports the world, and which one day they will cut through. They are personified as being of evil shapes-huge men with goats' or asses' feet and wooden shues, and when they stand erect their heads are higher than the highest chimney. In short, they are the modern

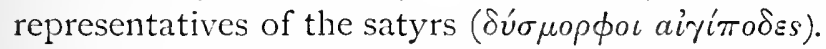

Next day, in spite of the mist and rain in which Komiakè was enshrouded, we set off to visit the unfinished colossal statue of Apollo, which lies near the sea, at the foot of the mountain. Soon after leaving the village we emerged from the mist and had a glorious day. The path led through a fertile valley, where some of the finest orange trees in Naxos grow on a property belonging chiefly to our host, the demarch.

Down by the sea is the marble hill of Naxos, which was worked as a quarry by the ancients, and close to which are numerous traces of antiquity-steps down to the sea, Ionic columns, \&c. On one side of the hill is cut in old letters OPO X XPIO؟ $\Gamma$... AIIOA $\Lambda \Omega N O \Sigma$. Hence the hill is still known as Apollo's Hill, and the unfinished statue as one of Apollo. It lies at full length in the quarry, out of which it has been hewn. From the sole of the feet to the crown of the head it is thirty-four feet long, across the chest it is sixty-eight inches, and eighty inches is the length of the arm from shoulder to elbow. It has evidently been intended for an erect, naked statue; the left foot is a little advanced, the arms from the shoulder to the elbow rest on the side, and are then stretched across the breast, which is very prominent. Locks of hair hang over the forehead, and at the chin a piece of marble has been left, as if for a beard. It is all unfinished, but quite sufficiently advanced 
for one to be able to trace every limb; and very huge it looks as it lies on its back in the quarry, surrounded by mastic and shrubs. It is, of course, mere speculation to argue about its intended destination. Was it intencled to replace the Naxiote statue of Apollo at Delos, which had been destroyed? IVas it never finished because the marble was found to be imperfect; for it is obvious that the piece was not a good one, though it may have deteriorated with time and exposure; or was it unfinished because some war or pestilence came to put an end to their work? Curiously enough, in Naxos I saw several unfinished statues. I was shown one of a woman at Potamia, and another has been found lately at Melanes; Ross says he also saw one : so it seems as if there had been a cause for this, which now we cannot tell.

After a warm, pleasant day spent down by the shore we returned to our mist and our damp at Komiakè.

There was loud grief and lamentation in one of the houses next morning; some parents had lost a child of two years old - the fourth of the same poor family which had sickened and clied-so they thought some spirit $(\sigma \tau o \iota \chi \varepsilon i o v)$ must haunt their dwelling, and that they must move. How anybody could live there at all, I wondered; for the floor was muddy and in puddles, the roof was dripping, and the whole accommodation for the family was this one room, and yet they were surprised that their children dropped off from cold and colic, and put it down to supernatural causes.

The funeral and the wailing were to be at ten; and curiosity prompted me to go. The mother was sitting in a corner howling as I entered. ' $\mathrm{O}$ my darling, why hast thou gone? who has cursed us? what evil spirit haunts my dwelling, that my children should die?' Her miserable 


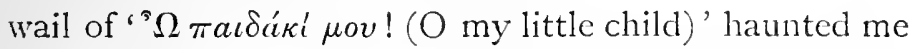
for days. Presently in walked the old grandmother, with a sack on her head, to join in the lamentation; and as my eyes grew accustomed to the darliness of the hovel I became aware that the dead baby lay on a box in one corner of the room, tied up like a bundle in a shect. Shortly after my arrival the hired lamenter, the marologista, entered and commenced her howl in simple poetic words :-

'To-day the heavens are darkened, the sun is obscured; to-day the child is cut off from his parents. It was not a tree that you could fell it, it was not a flower that it should fall ; but it was a weak young tendril, which twined itself around their hearts.'

Piercing and heart-rending were the shrieks that the parents uttered at these words, and as they subsided the marologista continued :-

'Would that I could descend to Hades, and gnash my teeth, for, lo! the worms of the earth to-clay have joy. Whenever I think of thee, my darling, whenever my mind ponders on this gricf, as the sea I am disturbed, as a wave my mind is troubled!'

By these pathetic strains the grief of the poor parents was nurtured; they tore their hair, they beat their breasts in their anguish until the priests came, and a table was spread with oranges, figs, and mastic, which refreshments were handed round to all present. Here at Komiakè a Christianised form of the old classical 'obolos for Charon,' the freight money, is still maintained, and still bears the ancient name of $\nu a \hat{v} \lambda o \nu$; it is not a coin as in olden days, but a little wax cross with the initial letters I. X. N. ('I $\eta$ sov̂s Xpıstòs Nıкâ, Jesus Christ conquers) engraved thereon ; and this they put on the closed lips of the deceased.

Thus is it that Christianity has introduced into its 
ritual pagan rites. If you go into any cottage in Komiake, and question the people about Charon, they will tell you with implicit faith, nothing hesitating, that he lives in Hades, a frozen spot ( $\left.\pi a \gamma \omega \mu \varepsilon \varepsilon_{\nu} \mu \mu^{\prime} \rho o s\right)$, where he hunts and chases his victims on a spectre horse to prevent their escape. Christianity has added to mythology by introducing on the scenes a personage called Charon's mother, doubtless from the analogy of the virgin mother of our Lord, who intercedes for sinners; so Charon's mother is personified as a sweet, tender woman who intercedes with her bloodthirsty son, and checks his murderous hand, saying, "Take not the baby from its mother; take not the newly married bride who wears her wedding garland.' 1 There are prayers to this mother of Charon very touching and pathetic in their expressions.

When once we had left Komiakè behind us, and crossed the mountain barrier, we breathed freely again. No more fear of being snowed up in those villages, lost away behind the Naxiote mountains; and as we approached the sea-level the air became genial and warm once more. I do not wonder at the ancient dislike of mountains-cold in winter, hot in summer, and shutting out those sea breezes which temper the climate in every season. We stopped for refreshments at the monastery of Phaneroméne, where the old monks observe a rigid discipline, and do not admit ladies within their walls. The strict rule of Mount Athos is maintained here, and my wife contemplated a dreary rest on the doorstep; but the akonomos was tender-hearted, and said that as she was an exceptional traveller he would make an exception in her favour. It was amusing to see how tinid the monks were at this intrusion; they would not hand her anything, but always got one of us to do it; and when she offered to shake

1 Passow's collection of ballads. 
hands on leaving they just looked at her and bowed stiffly. They have in their possession the most miraculous picture in Naxos, which was found, they told me, in the ground by the sailors of a ship who were fleeing from the fall of Constantinople in 1453 , and who were attracted to this spot by a mysterious light.

The akonomos did the honours of the place during the absence of his superior, showed us the treasures, and regaled us rvith coffee, nuts, and sweets.

The village of Engarrais was to be our destination for the night, the chief of several tiny hamlets on a plain to the west of the island, surrounded on all sides by hills. This little plain is one large orange garden divided into lots by hedges of tall reeds; these reeds, when fully grown, they cut down and use for making the ceilings of their flat-roofed houses. In Lesbos this reed is still called $\nu$ a $\rho \theta \eta \kappa a ~(\nu a \rho \theta \eta \xi)$, a survival of the old word for the reed by which Prometheus brought down fire from heaven. One can understand the idea well: a peasant to-day who wishes to carry a light from one house to another will put it into one of these reeds to prevent its being blown out.

The best house in the hamlet belonged to the priest, so accordingly we made for it; and he received us kindly. Papa Andréas was a widower, not forty yet, rotund and cheery, and he told us that evening, with a sigh, how priests in the orthodox Church were only allowed to marry once, and this one marriage must take place before they are actually ordained. Papa Andréas looked as if he wanted a wife to look after him; his long gown was green and greasy with age and neglect; his plait of hair, which well-regulated Papas usually fasten up with hairpins, was generally to be seen hanging down his back like a pigtail, or if not it was 
tucked into his tall hat, and stood out behind like the handle of a teapot. He walked about on tip-toe, smiling benignly upon us, and his ideas of the duties of a host knew no bounds. His eldest daughter wandered listlessly about with a baby in her arms ; she was married, and a mother, and only sixteen. 'This is not my first baby,' she said on our noticing it; 'I had another before this, which was far more beautiful.' Here it is the custom for children to marry at a very early age, and the priest said that when his wife died he got his daughter married as soon as he could, that she might have somebody to look after her.

After we had dined most of the inhabitants of Engarrais came in, and the priest gave a little dance in our honour. One of their local dances, here called the tirlà, is interesting, being danced by men and women in a semicircle, with their hands on each other's shoulders. The step is much the same as a mazurka, backwards and forwards, but the charm of it is the singing, which the dancers carry on in parts as they move to the tune of a syravlion and drum; this dance must resemble very much the ancient öpros, which, as Lucian remarks, presented a chain of intertwined manly courage and female modesty.

The next dance they performed for us was very extraordinary and wild in its character; they call it 'the dance of the Kalkagári,' those unearthly spirits of which we had heard so much at Komiakè. Two active men dance it together, with a rapid jig step, stooping and gesticulating at each other; one bobs down as he dances and passes under the leg of the other, backwards, forwards, round and round, and then one of them pretends to fall down dead on the floor, whilst his companion dances stealthily around him, over his legs and body, making comical gestures as he cloes so; then finally raises him 
up, and they both go on dancing as before. No wonder in their vivid imagination the peasants believe that the Kalkagári dance this weird, unearthly dance, whereas the lovely winged Nereids are supposed to be for ever whirling round and round in the graceful syrtos.

This last dance seemed to excite the spirits of the men for gymnastic exercises, and it was forthwith proposed to play athletic games for our amusement, such games as they play in carnival times and festivals amongst themselves.

The first game they played was a rough species of morra called $\pi \dot{o} \sigma a$ (how many ?). Six men were playing it, three on each side; the three on one side were the beasts of burden ( $\tau \grave{a} \zeta \hat{\omega} a)$, that is to say, they turned their backs to the other three, who jumped upon them. Having done this one of the riders puts one hand over the eyes of his beast and the other in the air, with some fingers extended, and cries $\pi \dot{o} \sigma a$ (how many ?). When all three beasts of burden have guessed aright they change places with their riders and guess in their turn. They laugh and jest a great deal at this game, and when a beast of burden is stupid he receives sundry boxes on the ears and general rough treatment from his rider. This game has its parallel in the Italian morra, and in the ancient Greek

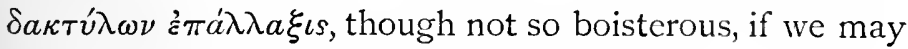
judge from a vase in the Munich Museum.

The game of 'barrels' is a most acrobatic one; four of the strongest men-round, sturdy, broad-shouldered men-played it. Two of these went down on their hands and knees, head to head, the two others, folded in each other's arms, turned a somersault on the backs of the others.

'Cock-fighting' is another rough game: a man went down on his hands and knees, and the two combatants 
took up their position on either side of him, and with violent struggles attempted to get through to the other side by the arch which the man had made with his back.

'The packsaddle' came next: a ma1 knelt, and two others, grasping each other's feet, fastened themselves around the kneeling man's neck, so that they hung like packsaddles on either side. Then the kneeler arose and whirled them round at a furious pace, until they fell off, amidst the laughter of the spectators.

'The bee' was a clever, sharp game; a little fat man played it most admirably. Three men stood in a row with their feet touching, the fat man in the middle, with a loose cap on, buzzed into his hands like a bee, whilst the other two stood with two hands in the air and the two next the bee ready to protect themselves. Then the bee buzzed and buzzed, and bobbed and bobbed, until he saw an opportunity for striking one of his opponents, the game being to knock off the bee's cap before he bobs again after he has administered a blow. Our little fat man was most adroit at this game; his hat was nerer knocked off, and the blows he administered most frequent; other bees who took his place were by no means so clever.

They kept up these games to a late hour that night, and the priest's house was the scene of unwonted festivity; never since his daughter's marriage, he said, had there been such gaiety in Engarrais. They were a kindly people, and expressed much pleasure at seeing English persons for the first time amongst them. They brought out of their houses everything they had in the way of embroidery or treasures to show us, and amongst other things they brought us the remnants of a curious old

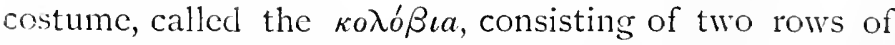
knittcd string, which was stiff enough to stick out at 
least half a yard behind the wearer; and it was worn by all the women of Engarrais, the priest told us, when he was a boy, underneath their dresses, to make them stand out behind. He was much amused when told that fashionable English ladies wear the same things nowadays, and call them 'bustles.' 'I had thought,' was his sage reply, 'that the English were more civilised than we are, and yet our women have abandoned these foolish things these twenty years.'

On quitting Engarrais next day we passed through one of those charming valleys which in Naxos they call a regma-long narrow hollows amongst the cliffs formed by the action of the water. A dashing stream ran through the middle, and on either side rose fantastic rocks; and if it were not for the oleanders, carob trees, and olives one might have fancied one's self in Scotland. This gorge led towards Melanes, a spot of fairylike beauty, buried in a narrow gorge, in a nest of olives, oranges, pomegranates, and cypresses. The village is conspicuous for a tall, dignified Venetian tower, with machicolations and battlements which stand in its midst, and behind are the fantastic peaks of Koronon rising up like the background in one of Titian's pictures.

After quitting Melanes we soon emerged once more into the plain of Naxos, but before returning to the capital we made a little détour southwards to Tripodes, near which place we heard that many Hellenic remains existed. This corner of the island is called the deme, or division, of Biblos-an old name in Naxos, which is thought to have been the name which distinguished the wine called $B \iota \beta \lambda \hat{\imath} \nu o s$. Close to Tripodes are many graves and remains, which go by the name of $\Pi o \lambda i \chi \nu \eta$; another instance of how old names and old words are still preserved up in the mountains of Naxos. Tripodes 
did not in itself repay us-rather the reverse, for its position is bare, in a gully leading down from the mountains to the sea : the houses are dirty, and our host, the demarch of the place, kept a most disagreeable wineshop. Our bedroom was of the worst, without a door of any kind; so that a sheet had to be hung up over it, the existence of which numerous inquisitive dogs and cats entirely ignored. But here occurred an instance of Greek character for which I was not prepared. As we were laughing at dinner, Gabalas, the jocose muleteer, volunteered to give us a lamb if we would return to Chalki, and spend Christmas there. I told him, using a Greek expression, that his promise was in the air; whereat he became indignant, and said he would go all the way to Chalki to fetch it. I must say I did not believe him, and said, to test him, that if he went for the lamb he must bring a handkerchief, too, which we had seen there, and a duplicate of which, I felt sure, could not be found elsewhere. To our intense surprise, he set off in about half an hour. 'He will not return,' said the others; but sure enough on the following evening Gabalas turned up with the lamb and the handkerchief at Naxia, having travelled night and day. If all Greeks were like Gabalas the country might have a future yet.

Next morning we rode off to an Hellenic tower, called i'laka, which has guarded one of the most fertile little plains in Naxos. About fifty feet of this tower are left standing, and one window; the tower was nearly square, being ten and a half yards by twelve and a half yards, and stands on a gentle eminence, and is built, as usilal, of mortarless stones, long and flat. Close to the tower we saw several graves cut in the rock, and about two hundred yards from the tower is a granite quarry, from whence the stones to build the tower 
were evidently cut, for we saw the chisel-marks on a gigantic stone here which had been in the process of being cut, and which corresponded exactly to the dimensions of a stone I had measured at the towernamely, two yards two inches long, twenty-six inches deep, and twelve thick.

There came on just then a terrific storm of hail, and we were unable to prosecute our journey southwards, and, to our regret, we had to leave the tombs and remains of Polichne and Delion unvisited, for our return to Naxia was imperative; bad weather and storm had delayed us enough already. Nowhere except in the mountains of Naxos did we suffer much from rain in the Cyclades; but at Naxos it rained in torrents, and our return journey from Tripodes to Naxia was made in one of these drenching downpours. We stopped for a time in a shoemaker's shop at the small village of Leonides, and we watched the man and his three apprentices hard at work. He said he generally had three apprentices about him, and he explained to us the meaning of a Naxiote proverb otherwise unintelligible, "When the quince comes they sit on their stools.' When winter is coming on, and the time for working by lamplight has come, a Naxiote shoemaker presents his apprentices each with a quince; during winter evenings they work longer on their stools, for there is less to do out of doors, and perhaps less inducement to amuse themselves.

We did a lot of business as we sat in the shoemaker's shop, for we bought a turkey to ensure us against famine in the capital on the morrow, Greek Christmas Day, and we became the happy possessors of some rich red Cretan embroidery which a peasant woman brought for us to see. That evening found us again in our old quarters at Naxia, awaiting the steamer. 


\section{CHAPTER XV.}

PAROS.

ON landing at Paroikia, the chief town of Paros, you immediately come in contact with the speciality of the place: the little jetty on which you land is made of marble, marble pillars for mooring boats to are jotted here and there, and you realise before long that Paros is nothing but one huge block of marble covered with a thin coating of soil.

In ages long gone by these central islands of the Cycladic group-Naxos, Paros, Antiparos, and the uninhabited islets of Despotiko and Strongylo-must have been united; in the straits between them are evidences of habitations, and in historical times from their proximity they have collectively been called Paronaxia ; and Paros, with her excellent harbours and her rich vein of marble, was always considered the chief. In Turkish times the Kapitan Pasha always anchored off Cape Drio of Paros to receive the annual tribute of the neighbouring islands ; Venetian fleets put into the harbours of Naoussa and Paroikia, and cut down all the wood that they found within reach; the coves and caves of Antiparos were the favourite haunts of pirates: and the result of all this has been to make of Paros one of the most dreary, desolate islands of the group.

The Athenians during their lordship levied from Paros twice as much tribute as they did from Naxos, Andros, 
and the other larger islands; and in travelling through Paros I found traces of a vast population in former ages. Extensive graveyards of the prehistoric, or so-called Carian, period, and of the Hellenic and Roman pcriods, are dotted all over the island; so that we may safely presume that Paros was a great centre of life in ancient days, and that this activity was due mainly to its wealth in marble.

There can be no doubt whatsoever that Paroikia is built on the ruins of the ancient Pariote capital; the place is teeming with remains-inscriptions, scraps of sculpture, and decorations are let into almost every house - but as it is at present Paroikia is a horrid place, for it lies so low. An acre or more close to the landing-place is a salt marsh, called Plaka, productive of malarious fevers in the summer heats; and the town is filthy, though the sea occasionally comes in and washes the streets for the inhabitants. The valleys and hills around the town are dotted with tiny white churches, as is so often the case in unhealthy fever-stricken spots; one of these, which was erected by a grateful sailor in a niche by the coast, and dedicated to St. John the Theologian, rivals any I ever saw in smallness, being only about two yards square. Convents, too-for the most part disestablished and converted into granaries and stores-abound all over the island ; there is one dedicated to St. John the Rainy, another to our Lady of the Lake, another to our Lady of the Unwholesome Place, another to St. George of the Gooseberry, a rare fruit in the East, and, most extraordinary name of all, there is a church dedicated to the Drunken St. George. Here, I thought, must be a true descendant of Bacchus; an instance of how the Greeks still love to deify the coarser passions; and on enquiry I was told that on November 3, the day 
of the anniversary of St. George's death, the Pariotes usually tap their new-made wine and get drunk; they have a dance and a scene of revelry in front of this church, which is hallowed by the presence of the priests. Down by the coast is the sailors' church of St. Nicholas the Seafarer $(\Theta a \lambda a \sigma \sigma i t \eta s)$. It was the eve of St. Nicholas on which we landed on Paros, and this little edifice was crowded to excess with worshippers, and was prettily decoratcd with flowers; on the floor were strewn sprigs of myrtle and sweet-smelling herbs, and as we vandered through the dirty streets we found the wineshops were gay with feasters.

Into one of these we entered, to hear four youths singing to the tune of an instrument which was new to us;

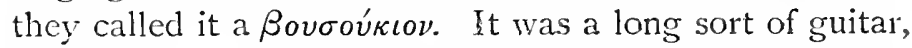
with six strings and eighteen notes, and prettily inlaid. They sang us a love-song about its being forty-five Sundays and sixty-two Tuesdays since they had seen their dearly beloved, until she came to church on St. Nicholas' Eve, with two smart handkerchiefs around her neck, and set their hearts beating fast. Greek love-songs are simplicity itself, some rather touching, but for the most part silly; yet these songs are nothing to the tameness of the jolies at which they laugh; and no island comes in for a larger share of puns than Paros, from the fact that paro, the patois for 'I take,' and Paro, the island, give ample scope. They are both pronounced as if they were written Baro, and they say, 'From Paro I do not wish to take cither fowl, or egg, or any female thing.' This pun on Paro is repeated over and over again in the little distichs and trite sayings of the islands.

Another curious instance of insular wit is shown by a popular interpretation of the origin of the names of the islands, which, though it begins well at first, gets exces- 
sively wild as the production goes on. It runs as follows:

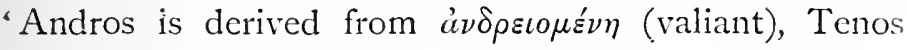

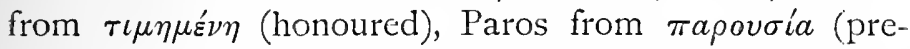
sence), Syra from $\psi \varepsilon \hat{i} \rho a$ (a louse), Mykonos from $\kappa a \sigma i \delta a$ (scurf on the head), and Zea and Thermia from $\pi \circ \lambda \lambda \grave{a}$ $\tau \grave{a}$ हैं $\eta$ (many years to you).'

We were lodged comfortably enough at Paroikia in a good house, with a balcony facing the sea, belonging to an old widow lady, whose husband had been a sea captain, and who took care to tell us that she was related to the great Mavrojenes of Paros, who had been hospodar of Wallachia. She apologised most humbly for not giving us her best room, but the fact was a sister of hers, a nun, had just arrived from the nunnery, and nothing could exceed the honour and respect paid to this old woman-poor thing! she had hip-disease. And though the nunnery was only two miles from Paroikia she had only twice paid a visit to the town since she was seven years old, and now she was sixty. No wonder that her advent quite eclipsed ours. She was propped up on the sofa and received visitors all the evening, amongst others ourselves; and the moment she saw us she begged for some English candle-grease, for, she said, nothing did her poor hip so much good as to rub it with that.

We had to superintend the cooking of our own dinner, and our supplies were not only exceedingly scanty, but were reduced by a foolish mistake of mine. Seeing a man staring at us as we ate I thought he must belong to the household, and asked him for another plate. This he interpreted into an invitation to share our meal, and accordingly arrived, not only with a plate, but with knife and fork and chair, ready to discuss with us our solitary woodcock. Perhaps he was a Mavrojenes and a descendant of the prince of Wallachia; at all events, we 
never had the satisfaction of knowing it. Ross, in his travels with King Otho, tells us an amusing story of this family forty years ago. When the king visited Paros two brothers Mavrojenes were deputed to receive the sovereign, being, as they were, of such illustrious descent. So accordingly they did what they thought to be the right thing-they hired two sturdy Pariotes and told them to prop up his majesty on either side as he walked. They performed this office with such zeal that poor King Otho could hardiy get on at all, and with difficulty persuaded his subjects that in Europe kings are allowed to exercise their own limbs. King George has not been here yet, I believe, but I do not think he will find that much advance in civilisation has been made.

The great sight in Paros is the Church of Our Lady of the Hundred Gates ( $\left.\varepsilon_{\kappa} a \tau o \nu \tau a \pi v \lambda \iota a \nu \eta\right)$ ), about five minutes' walk from Paroikia. It is by far the finest church in the Egean Sea-in all Greece, I believefor everyone asked us if we had seen it, as if it was St. Peter's at Rome. Externally it does not present a very attractive appearance, being surrounded by a whitewashed wall with innumerable windows, so that I suspect the hundred gates refer to windows, for there are certainly only five gates; and it is just possible there may be so many windows, though I did not count them. Inside this wall is a garden, and round the garden a cloister; the celebrated church is opposite to you as you enter. On either side of the portal two ancient marble satyrs support the jambs, beyond these there is nothing outside of any attraction.

You enter a narthex with tombs of mediæval worthies of Paros around it. Originally the narthex was intended for catechumens and the second order of penitents; by degrees, however, it was considered the befitting place 
for apostates, murderers, and women, individuals who were not supposed to be good enough to enter the church. This custom is now obsolete, except in monasteries, where the monks are supposed to be voluntary penitents. They say many of their 'hours' in the narthex, and naughty people who are late for church stay there so as not to disturb divine service.

The Church of the Hundred Gates is noted for its great number of adjoining chapels, unusual in Greek churches. One of these is constructed out of an old temple, ${ }^{1}$ the pillars from which are considerably older than the date assigned to the church, which, tradition says, the Empress St. Helena founded by roofing over these ruined pillars of the aforesaid temple. Since then numerous additions have been made, and tradition further tells us that the big church, nave, choir, and sanctuary were designed by a pupil of the architect who built St. Sophia at Constantinople; and later additions still, during the Frankish occupation, have made of this church a perfect Babel of architecture. The tempelon, or iconostasis, that is to say, the screen which in all Greek churches divides the choir from the sanctuary $(\beta \hat{\eta} \mu a)$, because the holy mysteries must be veiled from the eyes of the laity, is excessively elaborate with rich gilded work and intricate carving. Behind this the sanctuary is formed for the double purpose of divine worship and for a consistory. In the circular apse are eight rows of stone seats, like the seats of an ancient Greek theatre, with a stone throne ( $\sigma \dot{v} \nu \theta \rho o \nu o s)$ for the bishop in the centre, approached by six steps. Here he sits when he presides at a synod, and

1 There are six pillars, eight feet high, and fluted with an unequal number of flutings (twenty-one to twenty-three) and with capitals, of which the lower sides of the four corners of the plinth are decorated with leaves in relief, in the form of lilies. 
just before this throne is an old fluted pillar on which the lamp burns when the bishop reads the liturgy, and by the side of each stone seat are holes where the priests place their processional lamps when sitting down.

Under the altar is kept an old heathen altar, with rams' heads and garlands around it, and over the high altar is a massive marble badacchino with a dome made out of one huge block; this, they told me, the Saracens had once tried to take away and had broken it in their vain attempt; for it is six feet in diameter and a truly enviable piece of marble. Under this altar is the sacred spring (íria $\sigma \mu a)$ which cures, they say, many invalid pilgrims on the annual festival day (August I 5).

The choir and nave arc fine, and are supported by some good specimens of Byzantine pillars. On a stone in the floor is the mark of a footstep said to have been made by St. Theoctista, and her spindle is also kept here as a sacred relic. Close to this spot is a chapel which was once set aside for Roman Catholic worship during the Latin occupation; but this ceased to be the case with the extinction of the Latin clement. Some of the chapels, with their old frescoes fast decaying with damp and green mould, attest to the bygone glories of the place. In the dark baptistry there is a splendid cross-formed font for immersion, covered with mosaics (opus Alexandrinum), in the centre of which stands a pillar for the light, and there are three Greek crosses at the side; this font is now only used for adult baptisms. There are chapels dedicated to the worship of St. Anargyris, St. Philip, the Holy Ghost-all covered with weird frescoes. Such is the great Church of the Hundred Gates of Paros, an interesting though conglomerated relic of past ages, and still amongst the inhabitants of these islands it is an cbject of the greatest veneration, sccond only to the altar of the great 
miracle-working Madonna of Tenos. 'By the Hundred Gates of Paros may I win him whom I love!' says the love-sick maiden. Once, says a legend, a young man challenged the Lady of the Hundred Gates to a playing contest on the syraclion, and went accordingly to the church to play; but the Madonna took no notice of his challenge. Just as he was getting up to go he accidentally knocked over the candlestick, and broke his flute; in this way did the Madonna prove her superiority and humbled the man-a somewhat mild modern edition of Apollo and Marsyas.

Outside the gates of this church have been placed in rows some large marble sarcophagi, which were discovered by the lately established Paros Mining Company in making a tram-line down from the mine to their works by the harbour. In doing this they fortunately cut right through the old necropolis of Paros, just a little to the north-east of the Church of the Hundred Gates, and the products of a very casual excavation have resulted in many valuable 'finds'-epigraphs, sculptures, rings, and divers island gems. The sarcophagi have excellent workmanship on them-one, two yards and three-quarters long, has six beautiful plaques on one side only; one representing a horse, a tree with a serpent twined round it, a man, and a boy. The necropolis of Paros would undoubtedly repay a thorough excavation, considering the things they have found, the wealth of the island in former ages-for Paros, according to the list discovered on the acropolis, paid twice as much tribute as any other of the Cyclades-and the monopoly of marble which she had. Paros, moreover, we know, was the home of many celebrated sculptors, such as Agorakrites, the pupil of Phidias, who sculptured the Nemesis of Rhamontes. Archilochus, the poet, however, 
is perhaps the most cclebrated Pariote. From Paros came the celebrated chronological monument, now at Oxford, which gives us so much information about Greek history from the time of Cecrops to 263 B.C. Consequently Paros ought to be the happiest of huntinggrounds for the archæologist; enterprise and money is all that is wanted, and neither of them is to be found amongst the Greeks.

A walk through Paroikia as it is to-day gives ample proof of what the town once was. Part of the old city wall is now in the sea, for during the lapse of centuries sad havoc has been made by the encroachments of the waves; but the old acropolis, on a gentle eminence, is still a prominent object; and the mediæval castle which crowns it is an everlasting monument of the Vandalism of the Frankish lords of Paros, for its walls have been built out of the drums of many pillars, placed with their circles outwards, in rows, alternately with flat black stones and the seats of the old theatre. The effect is curious, and certainly has the merit of originality; but to the archæologist, who here sees temples, public buildings, and theatres destroyed and turned to so base a use, the sight is one of extreme anguish.

The old town of Paros must have been of considerable extent: all the flat space between the sea and the hills bears testimony to having been built over; there are the remains of an old aqueduct which brought water to the town; there are some half-dozen of the steps still left which formerly went down from the acropolis to the sea; and the schoolmaster of Paroikia, who was our guide, told me that thirty-five years ago he remembered that this flight of steps was intact. At the top of the steps now stands a little church, dedicated to St. Constantine, with a cross of brilliant yellow tiles over the 
door facing the sea, inside of which are several remnants of the past.

The flat space, or Plaka, on which the sea is making such inroads, must one day have extended beneath the acropolis right away to a black promontory called Kopteri, so called because it looks so sharp and knifelike. This Plaka was, of course, once the quay of Paros, the foundations of which, and the houses which once stood thereon, are now, in many cases, buried under the sea.

Our guide now conducted us along the sea-coast, past pretty houses with balconies and trailing vines, and past picturesque fishing-boats and nets prepared for the morrow; and at every step we came across some new relic of the past. Presently we ascended a gentle eminence, and saw all that is left of the temple of Esculapius. Under the foundation is a reservoir of water, once doubtless the stream which was considered to have healing properties, and which was given to the suppliant sick. Unfortunately there are but few remains left-all one can see now is the size and extent of the foundations. Here they found a beautiful statue, our schoolmaster told us, just before the revolution, which the Turks appropriated. Into the wall of a neighbouring tenement was let a fine marble bas-relief representing a sheep being led to the slaughter. This tenement was inhabited for the time being by a party of gipsies, whose dancing bear was tied to a post close to the marble sheep, and formed a striking contrast.

Our energetic guide then led us round by a house, which had an inscription let into it about 'fruit-bearing Demeter.' 'Here,' said he, as he pointed to certain doubtful ruins around, 'was the temple of Demeter, and here it was that Miltiades broke his leg.' And as we 
stood there, gazing at some shapeless, ruins he gare us chapter and verse from Herodotus. I suspect ciery Pariote urchin who comes within the clutches of this schoolmaster is made to learn this passage by heart. His first remarks were explanatory:-

'Paros, you must know, in those days showed shocking Asiatic tendencies, just as if, for the sake of example, Paros had favoured the Turks in the war of independence; but, by the holy St. George! Paros has had enough of Asiatics since those days, and knows better now. Well, Athens told Miltiades to go and lay siege to Paros, demanding a tribute of one hundred talents; and after laying siege to it for twenty days the general despaired of ever taking the town by force, so he had recourse to strategy. A certain woman, who held an inferior post in the temple of Demeter and Persephone, which was just on this spot here, sir, was a captive from the mainland, and she wished to get home; so she went secretly to Miltiades and bid him come to the temple of Demeter and speak to her there if he wished to take the city. At nightfall he went to the temple, which lay on the hillside outside the city wall, but he could not open the gate; so he climbed the wall and entered the temple, which, you know, sir, was like one of the ascetic nunneries they have to-day, and where men are never admitted. When he reached the temple door Miltiades was seizcd with a mighty dread lest he should see some Eleusinian mystery, which the gods forbade men to look upon, and be cursed for ever; so he, in his fear, ran off, and in leaping down from the wall broke his thigh, and with difficulty got back to his ship.'

The poor little man grew quite excited as he related this story. He eridently had no shade of doubt as to the veracity of the father of history ; he had in his mind's eye 
pictured Miltiades writhing in agony on this very spot; at all events, the facts of the case, as stated by Herodotus, are corroborated by the inscription, and by ruins being found on the hillside outside the city wall, where approach from the sea was easy.

The rest of the afternoon we spent in wandering through the somewhat uninteresting streets of Paroikia, admiring the little bits of carvings and bas-reliefs we saw at every turn, and more especially a fine tomb which was let into the wall over a doorway in a house in the main street. On the next morning early we started for Antiparos, a desolate ride of two hours to the point where the ferry boat takes passengers across. About half-way to this point we passed two good houses by the roadside with shady gardens-quite little oases in the surrounding barrenness-where live the descendants of two families once well known in these parts-the Crispis and the Veniers, both of Venetian origin, and both of which held princely sway at one time in these islands. Over the doors were the lozenges with the arms of each. And they say these Italians transplanted on to Greek soil are very haughty and proud still, but somehow the soil does not seem to suit them; generation after generation their resources become impoverished and their status diminished.

On our return from Antiparos we spent another night at Paroikia under the same roof, before commencing our researches in highland Paros. We accomplished our journey up to the marble quarries with the greatest of ease by the little mule railway they have made from the mountain to the shore, to facilitate the removal of their marble. So we sent on our mules and baggage before us, and drove up to the mines with the manager

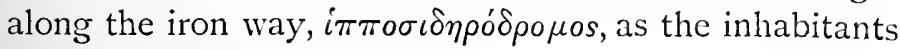


call it. It seems a formidable word to look at, but Greek scholars will recognise it sufficiently to heave a sigh at the base use to which the three classical words of which it is composed have been turned.

Every credit is due to the enterprise of the new Belgian company which have lately contracted to supply the world with Parian marble. Down by the harbour they have erected costly works, and have got all the latest improvements in machinery ; but unfortunately at first when they attacked the marble quarries on Mount Marpessa they worked at a wrong vein, so that a new shaft had to be opened ; and only now, after the expenditure of a vast amount of toil and money, have they at last got into the vein of genuine lyclnites-that brilliant sparkling marble so prized by the ancients for statuary and sculpture of every sort.

It would have been a long ascent on muleback to the convent of St. Minas, close to which are the various holes into the bowels of Mount Marpessa ; as it was, we were only an hour in making the ascent, and had a very pleasant journey. Not that Paros is in the least degree pretty-on this northern side it is almost the ugliest of the islands-but it was pleasant to sit and enjoy the ever-changing distant views, and see the shepherds run out of their mandras and gaze with eyes and mouth wide open at the terrible innovation which has actually found its way to the Cyclades. We saw quantities of bechives, too, constructed in the sloping ground-just rows of holes, lined with slabs, where the bees fix their combs ; for there is no need here of straw hives or our cunning northern appliances for kecping them warm in winter. Yet it was cold enough up by the quarries: a biting wind was blowing from the north, which made us glad to dive into the shafts, and made 
us shiver when we came out again. There is much débris of marble before the mines, and there are several holes into the mountain side, all of which were opened in ancient times. Into one of these we descended by a steep shaft, by the aid of miners' lamps. Very soon we were able to recognise the old chisel-marks, and in pursuing this shaft it was that the modern Parian Marble Company made their great mistake. To the right of us and to the left of us we passed various channels which the ancients had worked and exhausted the vein, and when we came to the depth of over two hundred feet we saw a huge block of marble just as they had left it ready to be hauled up. Their plan undoubtedly was to work all round the block they wished to get up, making it just small enough to pass up the shaft, and up which they must have dragged it by an arrangement of pulleys and props which we do not understand now. In many parts the shaft has fallen in, for the pillars left to support it have given way, owing to the weight above them. All these things were put to rights by the modern company at an outlay of much money, only to find when they reached the bottom, and got all the rubbish cleared away, that the vein they were following was all but exhausted; so they had to sink another shaft, and at length their efforts have been crowned with success. By a difficult passage lately constructed these two shafts have been joined; along this we crawled and came up by the other one. The manager told me that, according to his calculation, the vein of good marble extends one hundred and fifty mètres into the mountain.

Thirty years ago, when Ross went down the mine with King Otho and Queen Amalia, he said they had to crawl on their hands and knees to get down a very little 
way, and his majesty had to take off his epaulettes to enable him to proceed at all ; the queen, as she squeezed her way through, loosened some stones, which came upon her and terrified her exceedingly. On hearing her screams the king hurried back, and in this dark mine the bystanders were witnesses of a royal embrace of the tenderest nature.

There is a third shaft parallel to the other two which appears to have been of considerable importance in ancient times, for close to the entrance is the well-known bas-relief presented, as the inscription tells us, by Adamas to the nymphis : it is a wedding scene carved on the bare rock, the human banquet is going on below, whilst in an upper storey the gods are having another, at which Bacchus is presiding. Some Vandals, of-happily for themselves-unknown nationality, have removed the central figures from the lower banquet; so the manager of the mines, with commendable discretion, has had the whole bas-relief carefully covered over with wood to protect it, which he kindly ordered to be removed for our inspection.

The descent into the bowels of Mount Marpessa and the subsequent climb were productive of an appetite of considerable dimensions; so, before starting on our mule ride to Leukis, we lunched at a shanty the manager of the mines has built for himself close by-pleasant enough, I dare say, in summer, but miserable, with the four winds of heaven howling around, in winter.

Leukis is considered the gem of Paros, and before yoing there we heard glowing accounts of its beauty. it lies under the shadow of Mount Elias, the highest summit of Paros; there are plenty of olives, oranges, and lemons about it, and it is decidedly the largest place on the island; for, as in Naxos, these central valleys have 
escaped from the inroads of pirates and others in search of wood. The entrance to the valley at the top of which Leukis is situated was protected by two other villages with medirval fortresses, Kephalo and Kosto, the former of which was the last stronghold of the Venier family, and which Barbarossa only conquered by cutting off the water supply.

But Leukis is by no means a bright white place ( $\lambda \varepsilon v \kappa o ̀ s)$, as its name indicates; it is dirty and black in the extreme, the only white thing about it being a hideous new church with an elaborate marble tempelon, a marble throne, and a marble pulpit-not that they want pulpits one bit in Greck churches as far as I could see. In former days they used to read the prophets, epistle, and gospel from the ambon; now they do this on the soleas, or steps outside the sanctuary, and do nothing in the pulpit. Over the entrance door outside is a curious marble slab on which is sculptured a portrait of the worthy man who founded this edifice in I 830 : he is depicted as a regular islander, with his wide baggy trousers and the skouphica, or pointed fez, on his head; and in one corner of the slab is the hand of God pointing out of a cloud in the direction of the meek but beneficent-looking old man. From the churchyard the view over the sister isle of Naxos, with its lovely fantastic peaks, was very charming, far surpassing anything to be seen on Paros.

We had a pleasant walk that evening with the demarch, who showed us with pride the orange and lemon groves and the numerous wells of flowing water which make of Leukis the most favoured spot on Paros. No one dares to draw water after dark out of these wells, for the waters slumber, they think, like human beings, and if they are disturbed the genius of the place 
will bring evil on the intruder. In common with other Greeks of the mountainous districts, the people of Leukis are highly superstitious; witches they have in quantities amongst them, which haunt the caves and rocks on the mountain side: they are old men or women, past a hundred, who go by the name of $\sigma \tau p i \gamma \lambda a \iota$, not unlike the Harpies of old, for they can turn into birds at will, and have sometimes women's heads and the bodies of birds; and about these witches the people of Leukis have lots of legends ( $\pi a \rho a \mu v \theta i a)$ which they tell, one of which relates how an evil woman haunts the neighbourhood, eating all the men she can find, until a prince shall come and conquer her, like Theseus and the Crommyonian sow. At night sometimes, says the legend, these witches come to houses, cut out the heart of a man, and have a feast; from dangers such as these the hero of the legend is generally saved by some extraordinary interference. Unbaptized babes are, however, their favourite food, and for this reason children wear phylacteries around their necks.

Here in Leukis we heard a good deal more about those Kalkagári of which Naxos had provided us with so much information; children born during the days between Christmas and Epiphany are generally supposed to grow into these unpleasant hobgoblins. It was close upon the time now, and expectant mothers were growing nervous lest their progeny should appear at this season. 'We know of sereral Kalkagári in Leukis,'said the demarch solemnly, ' children who have been born at this unlucky cpoch.' And then he told us stories of how these unfortunate youngsters would walk in their sleep and torment their rriends. 'We know of them,' he concluded, 'but we do not talk about them; for their parents do not like to have the fact alluded to. The only way of averting the 
disaster is to place a blessed palm branch (Baîa) over the door at the time of birth.'

That evening we had another of those festive gatherings which our island hosts loved to improvise for us, and a wild shepherd boy, clad in skins, came in to play music for the dancing. He was a primitive musician in very truth; his instrument, the much-loved sabouna, just a lamb's skin fastened at the head and feet, a big reed with two smaller ones stuck inside at one end of the skin, and a cow's horn to bring out the sound at the other; and to the music of this they danced the syrtos, with some local acrobatic variations, which made us realise why the island doctors recommended this dance for torpid livers and indigestion.

It was really a cold morning when we left Leukis, and our host, with the true hospitality so common to these mountain places, positively refused any remuneration for his kindness. Many of our hosts loftily refused any monetary present, but at the same time lead us to understand that their wives or children are more mercenary, and not above receiving a little remembrance; but the demarch of Leukis was different-all he would receive was a little black-handled knife which we gave him, saying, as he thanked us, that he should put it under his pillow when he slept to ward off nightmare. This is a common belief among the islanders, as also is another, that the white marks on finger-nails are signs of parental imprecations.

Our ride to-day led us over some of the highest mountains in Paros, over 2,000 feet above the sea-level. We ascended by a fertile gorge, and before leaving the region of olive trees we dismounted to visit an old convent which was dedicated to St. John the Rainy. The monks have long since been chased away, and there was 
no one there to satisfy our curiosity about the name, so we surmised that as it was on the slopes of Mount Prophet Elias, where they go in times of drought, there must be some connection between St. John and the prophet which is considered efficacious in producing rain in dry seasons. The convent buildings are now turned into a farm, where shepherds live, whose business leads them to the mountains, and the cultivators of the soil, who look after the adjoining patches of vegetation.

We now entered a rocky, windy district, and flakes of snow fell occasionally, to show us that even December in the Sunny South is not the paradise we imagine it in England ; not that snow falls often in the Cyclades, and when it does the inhabitants affect surprise, and are at a loss what to call it, for, having called cold rain snow ( $\chi$ ıova), they must needs have recourse to the word $\nu \varepsilon \phi a ̀ s$ to explain a snowflake.

Down on the other side of the mountain by the seashore is a spot known as the abyss ( $\mu \nu v \sigma \sigma o s)$; here, report says, sponge-fishers have seen buildings at the bottom of the sea, houses with windows and doors overgrown with seaweed, and often choked up with sand; pieces of pottery they affirm to have been brought up from the bottom of the sea. If this is the case it is another instance of the vast natural subsidences that have taken place in all ages in these islands; unfortunately the sea was not smooth enough for us to see anything; only our muleteer pointed out on the shore rocks of a easily split ironstone, which he said were the walls of the ancient town. True enough they resembled walls, but they were not. All about here the formation is similar, and it struck us as more than possible that the divers have been deceived, and that the name of the abyss is an unmerited one. 
We had a weary ride that afternoon across an uninteresting country to the south of Paros; we passed by another church dedicated to St. John the Theologian made out of a cave with a wall built on to it. Why is St. John the Divine the tutelar deity of so many caves ?-he protects the huge grotto of Antiparos and other caves. Is it because he was supposed to have lived in a cave at Patmos when he wrote his Revelation?

The shades of night came upon us before we reached Kypedos, a considerable village to the east of Paros. It is tolerably flat round here, and the country is a perfect mausoleum. We visited next day no less than three graveyards, and were shown lots more; some of them have Roman remains in them, some Hellenic, some prehistoric, embracing many centuries, and pointing to the constant going to and fro of nations at this spot in search doubtless of the precious marble.

The mediæval fortress built on the summit of an isolated conical hill, close to the sea, and commanding the strait between Naxos and Paros, repays a visit: it must one day have been a large and commanding spot, and is covered with houses and churches of the Venetian epoch. At the top is a disused monastery and a lovely church, dedicated to St. Anthony, whither the people of Paros repair once a year on the saint's feast-day. It is reafly too bad of the Greek Government when they disperse a monastery to leave no money with which the church and the objects of mediæval art can be kept from destruction. Here is a most exquisitely carved iconostasis, or screen before the sanctuary, covered with pictures, in rich gilded niches, carved vine-tendrils, and finely executed borders ; in short, a lovely piece of old carving which would be prized as a monument of the past anywhere in Western Europe; but now it is left to decay, so that one of our 
pious muleteers picked up a golden figure which belonged to it and nailed it on. It is the same everywhere ; these tempela are apparently considered beneath contempt in Greece, and evcrywhere are left in empty churches to rot and decay. In its wealthy days this castle church must have been rich in decoration, but the frescoes, too, are fast decaying with damp-those terribly realistic frescoes of the Byzantine School representing the tortures of the wicked. In those days they apparently recognised the stomach as the seat of the spirit, and this fact is recognised in these frescoes by representing the devil dragging the spirit out of an ill-doer's mouth. I have actually heard the word spirit used for the stomach in ordinary parlance- $\pi 0 \nu \varepsilon i \hat{\eta} \psi v \chi \chi^{\prime} \mu o v$ (my stomach aches). On the floor is a fine double-headed eagle of Constantine, a usual object in Greek churches. On this the bishop stands when at his ordination; he pronounces the confession of faith in the presence of the kneeling populace, thereby showing that he inherits from Constantine the right of ruling over his flock.

From the top of the castle we looked down upon an evidence of the failure of a Pariote marble company. Twenty years ago one was started up in the mountains, and blocks of white marble were brought down and laid by the scashore, but the company failed before they were shipped off, and now they are left there, looking from our eyrie above just like a flock of sheep.

We were again favoured by a warm sun for our journey from Kypedos through the plain of Marpessa with its villages. One of these, called Marmora, has lots of ruins about it, and drums of temples, one of which, we were told, was once dedicated to the goddess Marpessa, and recalled to our minds the legend of her husband Idas and the Caledonian hunt. Why her name lingers 
so long at Paros I cannot say. The marble mountain is called after her, and here apparently was her temple, some of the drums of which have been turned to an excellent use, for about half a dozen of them have been scooped out and placed around a well as troughs for water out of which the mules can drink. The Greek muleteers are generally kind to their beasts, and urge them on more by the hideous noise they make, than by actual beating; though in Paros we had little bits of wood, cut like pencils, with the points of which you can prick the beast if he is sluggish. But if you use this implement when the muleteers think it unnecessary you are sure of a reprimand.

Marmora is a wretched spot now, full of empty houses, for it is a fever-stricken spot, and the world seems to have migrated to the port of Naoussa ( $\nu a \hat{v} s$, vaòs), for if ever a town deserved to be called a haven it is Naoussa. In its gigantic harbour all the fleets of the world could be anchored in safe water; but, as it is, it is somewhat a dreary fishing village with the ruins of a medieval fort out in the sea, and some large buildings which the Russians erected when they proposed at the close of last century to make depôts for wide conquests in the archipelago. 


\section{CHAPTER XVI.}

ANTIPAROS.

\section{The Island and Grotto.}

Antiparos may in one sense be said to be a lucky island-it is a place without a history. In classical times it was ignored, in mediæval times it was deemed of no account; all we can say for certain about it is that, until lately, it was the hotbed of piracy-and its inhabitants are still anything but creditable members of society - and it has a very large cave.

The Pariotes look down on their neighbours with supreme contempt and call them kovpoviva, or crows. I was puzzled at this appellation, for we certainly saw more crows at Paros than Antiparos, and asked my muleteer. 'You must know, sir,' he replied, 'that of all men the Antipariotes are the most superstitious; and when I was young they were accustomed to take oracles from crows. If they saw a crow settle on a tree they would carefully observe on which side it was; if on the south side of the tree off they went in a hurry to shut the gates of their village, for this was an augury that corsairs were in the channel; if the bird settled on the north side all was safe, and they took no further heed: and so we always call them "crows."

Something strongly resembling the oracles taken from the Dodonian Oak, I thought, as I jogged along, 
and my interest was excited about the crows into whose nest we were about to deposit ourselves; but, as it turned out, we found our home for three weeks at Antiparos, not amongst the crows, but in the hospitable nest of the Swans-two English brothers, who work calamine mines on this island, and who not only assisted us in our digging operations, but gave us the rest that we much needed.

On the coast of Paros, just over against Antiparos, is a little church. When people want to be ferried across they leave the door of this church open as a signal for the rickety tub to come across and fetch them: this is all the means of communication the crows have with the outer world. The strait is very narrow, and between the two islands in former years the pirates built a wall in the sea, the passage through which was only known to themselves; so by this means they had an infallible escape from pursuit, and the honeycombed coast of Antiparos formed an excellent depository for their stolen goods. All the older inhabitants can tell wonderful stories of those days, when exciting chases after pirates passed before their very eyes. One story, which they are never tired of relating, and regretting that it will never happen again, runs as follows. A heavily laden merchant ship was hotly pursued by pirates, and, perceiving no chance of eventual escape, it ran into a bay of Antiparos, close to which is a large cave; here they deposited their goods and went away, hoping that the pirates would not find the things. The Antipariotes, however, were aware of this manouvre, and, after waiting for a little time, for fear of summary vengeance if the merchant returned and found his goods stolen, they one by one repaired to the cave, bringing back first one thing and then another until, as time wore on, and 
the merchants did not return, anybody who was in want of anything took a walk to the cave and helped himself.

A more wretched fever-stricken lot than the six hundred inhabitants of the one village of Antiparos I never saw ; it is just one of the usual fortified Kastros of the islands, with the backs of the houses fitting close together, so as to form a circular wall. It has gates which are now never closed, and its streets are filthily dirty; and, as it lies low, in summer time it is a hotbed of fever.

The priest, whom I afterwards learnt did not bear an excellent character, and who had narrowly escaped being unfrocked for his naughty ways, is the ruling spirit of the place, and seized upon us foreigners as his own particular prey. Where priestcraft is predominant, and more especially unscrupulous priestcraft, there is always unlimited superstition. And here in Antiparos we found it as our muleteer had prognosticated. They believe an old man and an old woman have the gift of prophesying death. The old man is especially clever at this, and goes hobbling about at midday, when the sun is at its meridian, to an old tower, in front of which is a little square ; here, in an ecstasy, he says that he sees those dancing who are going to die.

'Barba George,' for they call old men Barba here, said the priest who informed me, 'on this subject has very delicate feelings; he does not break the news to the doomed individual himself, but does it through a friend.'

People believe that these old wizards can never make a mistake-only once the old man was wrong. He saw three people dancing the syrtos in front of the tower, two of them had their hands joined after the usual fashion in the dance, the third had not; the two died, 
the third is alive to this day. In addition to this faculty of foreseeing the advent of the arch enemy, Death, Barba George and Kera Anna used to be adepts at foretelling the advent of pirates and at giving timely warning to the inhabitants, but this branch of their trade may be said now to be extinct; simple sheep-stealing, such as often occurs, is beneath their notice.

After a death no Antipariote will cross his threshold from sunset to sunrise, for three days at least, for fear of encountering the ghost. Taken altogether, we felt that these people were a degraded, superstitious lot, far behind many of their remoter contemporaries in civilisation and progress. It was St. Nicholas' Day, properly so called, when we reached Antiparos. It is excessively convenient for these lazy Greeks- the cve of their many feast-days and the feast-day itself are both considered as holidays. Services were going on in all the churches and dances in many of the houses, for, being an almost exclusively seafaring lot, they deem it necessary to show St. Nicholas special honour. The people of Antiparos, after the custom of all Greek peasants, dance the syrtos and the orchos remarkably well: the latter is for two only, and has very graceful motions, after the fashion of a hornpipe : and as a very plain young man and a repulsively ugly girl danced it together the musicians played music for them on a lute and fiddle, and sang as they played, in a painfully hideous key, the praises of the young woman, who, we were told, was shortly to marry her partner, as follows :'She with her attractive love and graceful air and beauty of face shall live with prudence, honour, and praise for long years with her loving spouse.' In this strain sang the bard whilst the happy couple stepped the orchos together and looked as few English couples under similar circumstances could look-utterly unconcerned. 
There is nothing attractive in the village of Antiparos; lots of octopodia were hanging up to dry in the sun in preparation for the Lenten feast; on balconies we saw red cakes drying, which are formed of the skins of grapes which have been pressed in the winepresses, and which, we were told, are sent to France to make claret with. We were soon ready to depart ; but just as we mounted our mules the priest camc out of his house and begged us to take dinner with him, but having already sufficiently refreshed ourselves we refused, whereupon he disappeared for a moment and came out with a morsel of fish on his fork, which I was obliged to eat, for not until we had tasted food could we drink of the excellent wine he wished to offer us to the success of our journey. And then, without regret, we started across the island to the more genial quarters of the English gentlemen who own the calamine mines here, to whose hospitality we were to be so greatly indebted.

Antiparos is not a fair island to look upon-treeless and mountainous, but covered with a superabundance of low brushwood which in certain seasons is radiant with flowers. In the centre of the island it is fairly well cultivated and covered with vineyards, but the vines are all blighted, and the Antipariotes are but idle husbandmen, and so far they have found their incantations and priestly curses of but little avail in driving away this blight, which will remain with them, I fear, till they attack the evil with more energy than at present.

Next day we visited the celebrated grotto, and as we approached it we were obliged to traverse a wilderness of stones. It was on his visit to this grotto that Tournefort's mind was exercised by his favourite theory, the vegetation of stones. But though it is nearly two hundred years since his visit I fancy the stones have progressed but 
little in the vegetable direction-they are fearfully hard still and unpleasant to walk upon.

The entrance to the grotto is about four miles from the village, and is a curious semicircular hole, about roo feet long by 60 high, at the top of a hill, just under 1,000 feet above the sea-level; gigantic stalactites guard the entrance, lifelike and terrible. No wonder the natives look upon

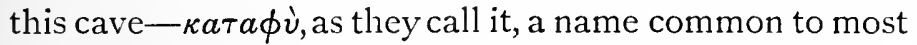

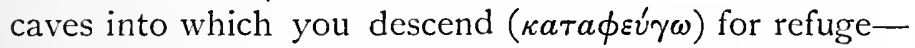
with superstitious awe, and before entering it many think it advisable to let off a gun, so as to drive away any ghosts or hobgoblins that may be about. In one corner of the entrance is a little church, dedicated to St. John the Theologian, where they hold a panegyris once a year, and where shepherds sleep occasionally, and hear strange noises rising out of the cave, which terrify them exceedingly; for this, say they, is one of the entrances to Hades. A herdsman who chanced to be with us asserted that he and another man once passed the night in this church and heard great stones falling on the roof ; they went out but saw nothing, yet all night the stones went on falling on the roof, so that they could get no sleep, and passed their time in crossing themselves and praying to St. John. Personally I felt much more as if I was about to enter the grotto of Thetis on the day of the marriage of Peleus; so much for associations-under different mental impressions they vary exceedingly.

Just inside the entrance is a walled-off enclosure, where some hundred or so young kids were bleating and sporting. Just over the entrance wreaths of wild capers and other aromatic shrubs hung gracefully down. It is indeed a wild, enchanting spot; it must have been well known to the ancients, though no mention of it is made, for there is an incision on one of the stalactites 
from which a tablet has been removed, and on a rock to the left is an old inscription beginning thus: 'E $\pi i$

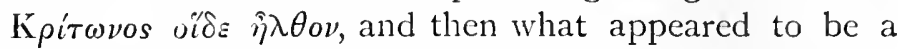
list of names : this was all the trace of antiquity we could see. Inside there was none, and I should much doubt if any ancient Greek, unless he was one of the deities of Olympus, ever ventured to enter this yawning abyss.

Now we were ready to descend; after going down a gentle slope for some thirty feet we reached an aperture four or five feet across, and here our difficulties began, and ropes had to be brought into requisition. It is not the pleasantest of all sensations to be dangling in the air over an abyss, the depth of which you cannot measure by the uncertain light of your torch, and to be solely dependent on your ability in holding a rope which is tied to a stalactite for your safety. Down, down we went, descending three difficult places by ropes and two by ladders until we were safely landed in a perfect sea of stalactites and stalagmites of dazzling beauty. We had brought with us a large quantity of dried brushwood ( $\phi \rho v^{\prime}$ ooya) with which to kindle a light, and by this means we were able to penetrate with our eyes the labyrinth of sparkling chambers. No wonder the timorous Greek recognises in this cave the palace of his unearthly Nereids and deitics belonging to another world; no wonder they tell stories of strange singings and dancings which are heard to be going on below : the shadows cast around us by our torches as we descended were enough to create all sorts of ideas in superstitious minds.

Here and there holes were pointed out to us which, said one of our men, no human being, to his knowledge, had ever penetrated, being too narrow ; but a tradition exists that a goat put in here in about two hours' time 
will turn up at a small church dedicated to the archangel Michael. We heard exactly the same story about the cave at Thermià, so we did not give it credence, and certainly did not intend to test the veracity thereof.

This vast hall, which we had now reached, right in the heart of the mountain, is seven hundred and twenty feet long, six hundred and seventy eight wide, and three hundred and sixty high, and resembles some lovely cathedral sparkling with gems, the dome of which is supported by elegant pillars of exquisite workmanship. Stalactites surround the edifice like statues of saints in niches, and stalactites in rows at one end remind one of an organ. It is not surprising that the idea of sanctity was suggested to the minds of the first modern travellers who descended here. At one end of this vast temple, screened off by stalactites, is a natural sanctuary with a ready-made altar, and at the end of it is a sort of pyramid which looks as if it were made of cauliflowers of marble. Two pillars in front of this were broken off by $M$. de Nointel to serve as a table for the celebration of his midnight mass in 1673 ; on the base of the pyramid are carved the following words :-

Hic ipse Christus adfuit

Ejus natali die mediâ nocte celebrato

MDCLXXIII.

This huge stalagmite is twenty-four feet high and twenty feet in diameter at its base, and beside it are rows of smaller stalactites, white and sparkling in the fitful light.

M. de Nointel was the French ambassador at the Porte, and a great archæologist, who travelled about and enriched the Paris museums in days when priceless gems were to be had for the trouble of taking. Out of 
some strange caprice he chose to pass three Christmas holidays in this grotto, accompanied by five hundred persons-his domestics, merchants, corsairs, timid natives who were bribed by largesses-any, in fact, who were willing to follow him.

It must have been a most impressive sight, that midnight mass in the bowels of the earth. A hundred large torches of yellow wax and four hundred lamps burning night and day illuminated the place, and men posted in erery arailable space, on stalactites and in crevices all the way to the entrance, gave notice by the waving of their handkerchiefs one to the other of the moment of the elevation of the host, and at the given signal explosives were let off at the entrance of the carern, and trumpets sounded, to herald the event to the world.

M. de Nointel passed the three nights in a small chamber close to the altar, whilst his friends scattered themselves about. The great difficulty was to provide food and water for so many individuals, as the inclefatigable ambassador was determined to wait here for three wholc days. Luckily for them a spring of fresh water was discovered inside the cavern; how they provided food for such a multitude we do not know. The suite doubtless found it exceedingly difficult to pass the time in this imprisonment, so we are not surprised to find that they amused themselves by writing their names on the walls and on the pillars with firebrands. It is curious to see how fresh and clear these names have remained after the lapse of more than two centurics.

A further but uninteresting descent of about eighty fect can be made beyond this hall, where all the most energetic travellers have penetrated and written their names, and amongst others Otho, the first king of the Iicllenes. 
We spent so long in examining the place that our stock of brushwood was nearly extinguished, and we were nearly choked with the smoke; so it was considered time to retire. Moreover our guides, and old Zeppo in particular, of whom more anon, grew greatly alarmed at the denseness of the atmosphere, and prayed us to begone. The ascent was no easy matter, but it was accomplished with the loss of a few buttons and the receipt of a few bruises, and then we were in a condition to enjoy immensely the excellent luncheon which was prepared for us at the top.

The remains of our candles were burnt by our attendants in the chapel of St. John the Theologian, 'because,' said they, 'he has to-day preserved us in the evil hoụr.'

\section{NOTE.}

\section{On the Prehistoric Remains of Antiparos.}

On ascertaining the existence of extensive prehistoric remains at Antiparos I felt that it would be a satisfactory spot for making investigations-first, because during historic times we have hardly any reference to the existence of a population here; in fact, the only reference that I can find to Antiparos under its old name of Oliaros is in an obscure author, Stephanos Byzantinos, who tells us that 'Oliaros, one of the Cyclades, aivout which Heraclides, of Pontius, in his description of the islands, says, "Oliaros, a Sidonian colony, is distant from Paros nine stadia.", This notice gives us a possible solution of the vexed question as to who these inhabitants were; they may have been early Phœnicians. The existence of calamine in this island may have been known to them, and have attracted large numbers. Only a few years ago calamine mines have been opened here; whether calamine and its properties were known to the Phonicians it is impossible now tn say. I could find no trace of any ancient works here, but they may have taken their mineral from near the surface and have left no trace of holes. Beyond a Venetian fortress and the present wretched village, 
the inhabitants of which are chiefly descended from reclaimed pirates, and a few houses near the above-mentioned mines, there are no traces of habitations on the islands at all ; certainly nothing of Hellenic work.

Secondly, I was induced to dig at Antiparos because I was shown extensive graveyards there. Of these I visited no less than four on the island itself, and heard from natives of the existence of others in parts of the island I did not visit. A rock in the sea between Antiparos and the adjacent uninhabited island of Despotiko is covered with graves, and another islet is called Cemeteri, from the graves on it. The islands of Despotiko and Antiparos were once joined by a tongue of land, which was washed away by the encroachment of the sea on the northern side; and in the shallow water of the bay, between the islands, I was pointed out traces of ancient dwellings, and with the help of a telescopethat is to say, a can with a glass bottom, which the sponge fishermen use here to see the bottom of the sea-I was able to discern a well filled up with sand, an oven, and a small square house. It would be interesting to compare these with the prehistoric houses found at Therasia and Santorin by the French School at Athens and with that on Salamis. Unfortunately the ruins were too much covered with seaweed for me, with the rude appliances at hand, to form any opinion or take any measurements. A clever fisherman, who knows every inch of the bay, told me that pottery similar to that I found in the graves was very plentiful at the bottom of the sea near the houses.

It is on the slope of the mountain, about a mile above the spot where the houses were, that an extensive graveyard exists. It is not unlikely that the submerged houses form the town of which this was the necropolis.

Lastly, I was further induced by the fact that the adjacent island of Paros was a great centre for settlements in all ages, owing to the marble quarries, from various nations and languages: but Antiparos had the advantage over Paros for excavating, owing to the non-existence of historic remains, so that we could start with a fair supposition that the extensive graveyards belonged to a period prior to history.

During my stay at Antiparos I was assisted in everything by the kindness of my friends the Messrs. Swan, who conduct the calamine mines on the island, and with the aid of their workmen I opened some forty graves from two of the graveyards. One of 
these cemeteries-namely, the one over the submerged houses already referred to-was greatly inferior to the other, in the character of the graves themselves, and in the nature of the 'finds' therein, though they all belonged to the same class of workmanship.

First, we will speak of the graves themselves. Most of those in the poorer graveyard were very irregular in design, some oblong, some triangular, some square; they generally had three slabs to form the sides, the fourth being built up with stones and rubbish. There was always a slab on the top and sometimes at the bottom of the grave. They were on an average three feet long, two feet wide, and seldom more than two feet deep. In every grave on this western side we found bones, chiefly heaped together in confusion, so much so that it seems impossible that the bodies can have been buried even in a sitting posture; and most graves contained the bones of more bodies than one. In one very small grave, so small that to get the remains of two people in they must have cut up the limbs, we found two skulls so tightly wedged together between the side slabs that they could not be removed without smashing them; from this we may possibly infer that the flesh had been removed in some way before interment, differing essentially from what Dr. Schliemann found at Hissarlik, where, he says, 'all prehistoric people who succeeded each other in the course of ages on the hills of Hissarlik used cremation of the dead.' This at once argues a great difference between the prehistoric inhabitants of Hissarlik and Antiparos. In the graves in the cemetery to the south-east of the island I found only one body in each ; they were considerably larger and better built; some of them had graves beneath, and in every case a slab or pillow on which the head was rested. One graveyard was essentially inferior to the other in point of wealth and advance in art, yet the nature of the 'finds' in each was the same.

I will, first, discuss the marble 'finds' in these graves. In the poorer graves I found the rudest representations of the human form in marble, which somewhat resemble a violin, both of which were in one grave and probably meant to represent man and wife. In one grave here I also found some flat round bits of marble, which I threw away as mere pebbles at the time, but after-consideration makes me inclined to believe that they were intended for the same purpose.

Secondly, the cemetery to the south-east. The representa- 
tions of the human form were certainly better, and show considerable advance in artistic skill; they have apparently been made by rubbing the marble with stone, so as to leave the nose and eyes.

There is always special attention paid in the female figures to the rulva triangle, doubtless pointing to a worship of procreative power; and in one figure found here the idea of the sitting posture is cleverly given, and there is a successful attempt to give the roundness of the calves and limbs. Two similar figures J got from Paros, perhaps indicating a further advance; the one with pointed legs I take to be a man, by comparing him with a similar figure in the British Museum. From Amorgos I got a still more advanced specimen of these quaint figures, being a group of which only is left the trunk of a woman's body, with the arm of another person round her back, probably a further representation of man and wife. In the muscum at Athens there exists one of these figures of wonderfully advanced execution; it represents a man sitting in a chair playing a lyre, and is really a work of fair execution, but they hare always the same curious pointed shape of the head, and unnaturally long neck; and it is puzzling to divine why, when they could round and finish off other parts of the body, the head was invariably pointed like the blacle of a stone implement. In some graves I found marble legs all alone, in another a headless silver figure covered with so heary an oxide that the form was almost destroyed; they probably must have had some religious purport, $e x$ voto or otherwise; and from the excess of female figures over male it is presumable that the people were worshippers, though not exclusively, of some female deity.

Besiles the figures there were a good many other marble things in the graves; large marble bowls, with vertical holes for suspension, are frequently found in similar grares in the Cyclades, and are called $\lambda v \chi^{\prime}$ áp Antiparos had a collection of shells from the seashore at the bottom of it, eridently put in at the time of burial as an offering to the dead.

I found also several marble plates well rounded, and with an idea of ornamentation in the rim round the edge, another dish with bits of marble left on the edge for ornamentation, and a neatly made phial with a lip to pour out of. Marble, of course, is a speciality of the Cyclades, and especially so of the neighbouring island of Paros, and doubtless was an object of commerce to these very 
people; so we need not be surprised at the skill displayed in working it.

We will next discuss the obsidian implements which I found. In the poorer graves in the first cemetery there was not a trace of volcanic glass implements, whilst in the richer ones obsidian flakes or knives were very common; but here again I found no arrow-heads, which occur in great quantities in other places where obsidian implements are found in Greece. In Antiparos the inhabitants had their obsidian close at hand, for a hill about a mile from the south-eastern graveyard is covered with it. I take it that the graves must date from the very first introduction of the knowledge of making these instruments, as there were none in the poorer graves, and flakes only in the richer ones.

Obsidian, of course, is found in abundance in other parts of the world, and old graves on continental Greece produce many similar specimens. Obsidian cores come from Hungary, Mexico, Terra del Fuego, \&c. Cerro de Navajos is an obsidian hill in Mexico, formerly the Sheffield of that country, where they made all their knives prior to the Spanish invasion. Quantities of obsidian implements are picked up now in the fields around there. When Cortès invaded Mexico he found the barbers of the Aztec capital shaving the natives with razors of precisely the same nature as the obsidian flakes I found at Antiparos.

The art of making them has perished, but the theory is plain; any maker of gun flints could do it. The Indians still have a plan of working obsidian by laying a bone wedge on the surface of a core and tapping it till the stone cracks; their productions are exactly similar to the flakes I found in Antiparos, as I have certified by comparing them in the British Museum.

In the next place I found a considerable number of metal ornaments in the graves at Antiparos. I have in my possession a narrow twisted torque of silver with a large percentage of copper, rings of silver with the same oxide on, as certain rings found in Etruria, which cuts like horn, a band of bronze with about seventyfive per cent. of copper in it, and covered with an incrustation of red oxide and green carbonate of copper, and that little silver figure I mentioned above, with a thick incrustation of chloride of silver; thus giving us silver, copper, and bronze in use at the time of these graves.

Lastly, we will treat of the pottery, which, after all, is the most important item, and demands our chief attention. Pottery such as 
I found at Antiparos is now for the first time associated with the marble figures and marble household utensils, thus giving us some little further insight into the advance the people who fashioned these figures had made in domestic art. On none of this pottery is there the faintest trace of writing or inscriptions, thereby suggesting that the people were not Phœnicians or Sidonians, as the legend says, for most I'hœnician remains have traces of inscriptions on them.

In the poorer graves we seldom found anything else but pottery: it is all of a rude character and frequently incised with rude patterns. The vase shaped like a sea urchin is covered with a sort of herringbone pattern, and stands about a foot high.

The pattern is common on very early Hellenic glass, and is the same as what we often see on ancient British vases. Most of the vases are very true, too much so to be hand-made, and consequently we may presume that many of them were turned on a potter's wheel. There is no trace, however, of a pattern from animal or vegetable life on these vases, all being herring-bone or criss-cross; this would place our pottery anterior to that of Hissarlik, on which we see attempts at the representations of eyes, noses, and breasts.

The clay is very poor and very slightly baked; much of it is black inside, as if the pots had been dried in a closed place, so that the smoke has penetrated the clay. Then, again, we have frequent specimens with bits of marble in the clay to prevent it contracting. As to shape, the specimens are very varied: there were lids without their bottoms, and frequent vases with a rim for a lid which was missing; most of them had vertical or horizontal holes, through which a string had been passed for suspension.'

Of course no importance can be attached to the following facts, but it is worthy of remark that in a cavern in Andalusia a fragment of a vase, now in the museum of St. Germain-en-Laye, was found with vertical tubular holes for suspension exactly like some I found at Antiparos. Similar ones have been found in Breton dolmens, and in the museum of Nordiske Oldsager there exists a vase found in a Danish barrow, covered with a lid, and having on each side corresponding perforations through which strings could be passed, exactly like one I found in the richest grave I opened in Antiparos. Curiously enough this grave was the only one I opened in which I found no trace of bones. I thought that perhaps traces of cremated

1 Most of these remains have been purchased from me by the authorities of the British Iluseum. 
bones might be found in the earth which filled the vase, but there were found to be none existing, and the earth had evidently made its way into and filled the pot through a crack in the side.

A vase in the British Museum from Porth Daforet, in Anglesea, has exactly the same pattern on it as one I have, and bits of marble, or quartz probably, in the clay to prevent contractions are very commonly found in ancient British vases. These points are merely speculations of course, and prove nothing, but still they are curious as prehistoric coincidences.

One further point with regard to this pottery I must mention, which perplexed me considerably at the time. About two hundred yards from the poorer graveyard I opened a small isolated grave, evidently that of a child; in it I found a lamp and a mug of much more recent date, probably at the most three centuries B.c. The grave was formed in exactly the same way as the others, and the only solution to the problem is this, that a child died on a boat which was storm-bound in the harbour, and was buried here, the materials and method for making the grave being taken from the neighbouring graveyard. Even now barques are frequently stormbound down there, and wait for weeks for a favourable wind to take them to their destination. With regard to a skull' I brought home from a grave in Antiparos I fear nothing can be proved from the study of an isolated specimen; suffice it to say that it is brachycephalic, an unusual circumstance for skulls found in Greece; and in other ways this skull differs entirely from those hitherto found there. By comparing several of the skulls some conclusions might be arrived at, but, of course, this would present difficulties.

Nothing can be decided without the aid of geology as to the dates of these graves; but with the aid of geology something might possibly be done, and it would turn on two points. First, as to the time of the submersion of the houses at Antiparos by the encroachment of the sea, which has evidently been brought about by the wearing through of the narrow slip of land between Antiparos and Despotiko; and secondly, as to the date of the first great convulsion of nature which changed Santorin from a lovely island, called $\dot{\eta} \mathrm{K} a \lambda \lambda i \sigma \tau \eta$, into a mass of pumice.

No tradition or allusion to this stupendous event is made by Herodotus or other writers, and Herodotus gives us the traditions

1 The skull I presented to the Royal College of Surgeons. 
of Santorin as far back as the sixteenth century B.C. M. Fouqué, the French geologist who went to Santorin to study the recent eruption, stated it as his opinion that the first convulsion took place twenty centuries B.c. Tradition, by its silence, and geology, by its surmises, combine in placing this eruption before the sixteenth century, and the 'finds' of the French School in Santorin and Therasia were of a date prior to this eruption, for the prehistoric villages were covered with the layer of pumice which resulted from that eruption, which in its magnitude must have equalled the recent calamity in the Sunda Straits.

Now, with the one cxception of marble, my 'finds' at Antiparos are inferior in artistic merit to both those of Santorin or Hissarlik, and hence doubtless anterior, for it can hardly be supposed that a knowledge of making superior pottery existed on one island and was unknown on another so close to it as Antiparos is to Santorin, especially as M. Fouqué proves that there existed considerable commercial intercourse between these islands.

By the contemplation of the vast population which inhabited the islands of the Egean Sea, we are carried back into the remotest antiquity ; and a vast population it must have been, for every island is full of these graves. In our travels we found many of the marble figures and bowls in the peasants' houses, which they had found whilst digging in their fields; but from observation I may state that the great centre of this population was Paros, for the eastern side of the island is a perfect necropolis, whereas the richest 'finds' and the best designed figures have come from Amorgos, and the rudest ones I have seen are those I found at Antiparos. I am convinced that a further study of this subject under a more vigorous system of excaration than I was able to bestow on it would result in many interesting facts becoming known about this primitive race of mankind. 


\section{Zeppo's Story.}

I had been opening the graves of the prehistoric inhabitants of the island of Antiparos for some days, and was getting weary of this sexton-like kind of life; accordingly, when St. Simeon's Day broke fine and cloudless, as February days will do in these parts, and when my grave-diggers refused to work, it being a saint's day, I determined to spend my compulsory holiday on the sea.

A day's fishing here amongst the Greek islands has many novel charms; new species of fish, new methods of catching them. And then the mongrel companion of my sport was exceedingly novel, too. Zeppo was his name, and Zeppo had a wonderful story to tell, the substance of which I already knew, but my friends told me to get Zeppo to tell it himself, and they assured me that I should never forget it.

He was a handsome man, somewhat orer fifty, with grizzled hair, and wore the wide, blue, baggy trousers of the Greek islanders, which wabble between their legs like the stomach of a goose; he wore on his head a red fez with a long blue tassel, and as he sat at the stern, holding the sail in one hand and the rudder in the other, I wished I had been a portrait painter, his appearance was so quaint. I knew his character well, for he had been our factotum for days past, knowing, as he did, every inch of the island. He had guided us to the graveyards where treasures were to be found; he had carried a pick and probed the ground for the gravestones, but when these were removed he invariably decamped, for he admitted 
to a dread of skulls and bones. Then he would light a fire of brushwood at a respectful distance and smoke a cigarette; nothing would induce him to come near the grave again. Zeppo was essentially lazy, highly superstitious, and not ashamed to admit his fear. He told me his father had been a pirate, but when the profession grew precarious he had wisely given it up, and settled at Antiparos as a vendor of foreign goods (principally smuggled) at exorbitant prices to the peasants, which trade his son and heir carried on with equal success. On his mother's side Zeppo boasted of Turkish extraction ; his name is Italian, as is often the case with the Greek islanders, so Zeppo is in every sense of the word a mongrel-a cringing coward, very cunning, and highly amusing. His great forte is fishing, and in his capacity of fisherman he is looked up to and consulted by all his neighbours.

To understand the following narrative it will be necessary to look at the map to see exactly the lay of the land, or rather the water, in these parts. Antiparos is the small island to the west of Paros, from which it is separated only by a narrow strait. It is a wild, barren island which knows no law. Even now, if the profession of piracy is virtually extinct, marauding is not, as the goatherds know full well, to their cost.

On the opposite side of the island to the village of Antiparos, about two hours on muleback over the mountains, are a few scattered houses gathered round the calamine mines. Here we were staying, close to our graveyard, and here Zeppo has his store and dispenses his goods to the miners. Separated from Antiparos by another narrow strait, which swells out into an excellent harbour just below these houses, is another island, Despotilio by name. This is four miles across, very hilly, 
and covered with brushwood, being let to two herdsmen for eighty okes of cheese and one kid apiece per annum, that is to say, about $8 l$. stering. Beyond this island of Despotiko yet again there is another small round island, called Strongylo ( $\left.\Sigma_{\tau \rho o ́} \gamma \gamma v \lambda_{0}\right)$, separated again by a narrow strait, and only visited in the summer by a stray goatherd in search of pasturage for his flocks. We sailed past it one day with Zeppo, who trembled like an aspen leaf at the sight of it, for his recollections of it were gruesome. Thus we have a chain of islands before us-Paros, Antiparos, Despotiko, and Strongylo. The two latter islands are fair specimens of the numerous rocks in the Egean Sea which nowadays are never visited except by shepherds. Yet Despotiko had its inhabitants in ancient days, for there are tombs thereon, and I excavated the foundations of a temple on the north-east corner.

On Despotiko live two brothers, Andronico and Stefano; they have a mandra, or hut, where they look after their flocks. They are the sole occupants of this island, and the only other building besides their hut is a little Byzantine church, the remains of a monastery which at one time was kept up by the women of Antiparos, who went across in turns to sweep and garnish it; but since Zeppo's adventure a year ago none will go near it, and it is fast falling into ruins.

Zeppo had now lowered the sail and was eager for the fray. We were to begin by catching an octopus or two, at which sport Zeppo is unusually clever. He stood in the bow of the boat in a round hole prepared for the purpose, with a tin can with a glass bottom in his hand; this he inserted into the sea, so as to be just below the ripple, and thereby got an excellent view of all that was going on at the bottom. He knew well the haunts, 
or houses, as he called them, of the octopodia, and as soon as he saw one through his glass he lowered his bait, and induced the monster to leave his lair. When it was sufficiently clear of the bottom not to be able to make use of its feelers, Zeppo let it have the bait, and soon the wriggling, writhing creature was landed in the boat. Zeppo was delighted. He took his prize in his hands, bit it on the neck, and out gushed a black stream of disgusting matter like that which comes from the cuttlefish, and gets for it its Italian name of the 'inkpot.'

The octopus writhed and wriggled for hours at the bottom of the boat ; it changed colour, like a chameleon, from brown to red, and red to blue, and died exceedingly hard.

'Mavaría rov !' 1 said Zeppo when he saw my surprise, 'if you put a dried octopus into water a year after its death the muscles would wriggle again.'

In Lent everyone eats octopodia in the Greek islands. It would be Lent soon, and as we drew octopus after octopus into the boat Zeppo's spirits grew high.

I thought my time for probing him about his story was come; like his octopus, I had got him clear away from the bottom, so I held out to him a bait.

' Zeppo $\mu o v$, good thing there are no pirates here nowadays,' I began.

Zeppo whistled a little, and then broke off into the favourite boatman's song in these parts about a wounded partridge, as if he had not heard me. So I repeated my remark. Zeppo was now busily preparing an iron ring to fix at the end of his trident ${ }^{2}(\kappa a \mu \alpha \xi)$ for pinna-fishing ; he looked up stealthily, and remarked slowly and with emphasis :-

1 The Virgin Mary.

2 Vide p. $2 \mathbf{I}$ 
'Don't believe them if they say there are no pirates now.'

I laughed him to scorn, and suggested how the British ship 'Cygnet' had cleared these waters of such vermin ten years ago, and thereby I made him clench the bait.

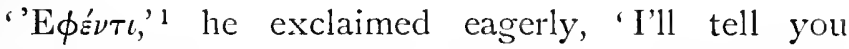
what happened to me last year over there in Strongylo, and then tell me if you think our shores are frce.'

Zeppo was now wriggling at the end of my line.

'Let's catch a few pinnas first,' I said, not wishing to appear too eager. So Zeppo rowed us to a shallow part he knew of as a good arena for this sport, and after scraping the bottom with his iron ring at the end of the trident he soon brought up several of the long, red pinna shells, the contents of which made us an excellent scallop that evening for dinner.

'Well,' said Zeppo, now volunteering his story, 'last year, about this time, I went across to Despotiko to shoot a few partridges, and I walked up the hill yoinder with my gun. After some sport I met the herdsman Andronico, and had a chat with him, so that it was getting late when I returned to the shore, and, as bad luck would have it, a heavy northern gale had set in, and I dare not cross to Antiparos that night.'

I laughed a little, and assured Zeppo that if there was a ripple on the water he would be alarmed, and then I hoped that he passed a good night in Andronico's mandra.

'No,' said Zeppo, 'unluckily I didn't; the mandrer is small enough, and both the brothers were at home that night. So I thought I would pass the night in the church by the sea yonder' - with this he pointed to the

1 Effendi. 
church I mentioned above, and I applauded his choice, for certainly the interior of Andronico's mandra is anything but an inviting resting-place. There is a bed in the corner, consisting of a cloak, or goat's skin chlamys, thrown over some sticks; the floor is mud, there is no door or window, the wind whistles through the stones, and you cannot stand up straight for fear of getting mixed up with the articles of husbandry that are concealed in the roof. Outside is an oval enclosure for the flocks, and the stench is insupportable. I hare been threatened with a night in a Greek mandra myself, but, like Zeppo, I have preferred a church. The church in question is close to the shore, and is surrounded by ruined cells from which the monks have long been driven; inside it is very mean, having a mud floor, no seats, and a wooden screen covered with a few sacred pictures of the Greek ritual, behind which is the bema, or holy of holies, where the priest celebrates those mysteries which must be veiled from the eye of the people.

'It was growing dark,' continued Zeppo, 'when I entered the church. I lit a light in the oil lamp before St. Michael's picture, I said a prayer to the archangel to protect me, and then lay down to rest.'

Zeppo, huddled up in a corner, with a stone for his pillow, could sleep very well, I knew, so as yet I felt no pity for him.

'Not long after sunset,' continued Zeppo, now warming to his subject, glowing with excitement, and using his hands and arms to express his earnestness when words failed him--'not long after sunset I heard men's roices from the seashore,' and he pointed to the spot, which was not twenty yards from the church, 'and I became aware that a boat was being drawn up on the beach; then I distinctly heard men coming towards the 
church, laughing and talking loudly, for they little thought anyone was within earshot. I began now to wonder what sort of men could be coming to deserted Despotiko at this time of night, and, fearing their object could not be a good one, I extinguished the light and crept behind the wooden screen, so as to be out of sight. Presently three men entered the church; they were Naxiotes-I could tell by their accent - and all the world knows that the men of Naxos are thieves. A horrible dread seized me. "They have come to steal some of Andronico's goats ; if they find me I am lost." '

Here poor Zeppo manifested such great agitation at the recollection of his terror that he trembled from head to foot, crossed himself violently, and lit a cigarette. My companion had all the cunning of a periodical about him, which doles out its stories in instalments by the month and leaves its readers in suspense.

'We must fish a bit now; I will tell you the rest afterwards,' he said. 'Let us try dynamite.'

I involuntarily started at this suggestion; but knowing the habits of these lawless Antipariotes I merely suggested-

'Dynamite indeed! Why, what would the demarch say ?'

"The demarch is miles away, effendi; and if he was here would enjoy the sport as much as ourselves.'

I afterwards found this was true enough, and, being curious, I allowed Zeppo to continue his nefarious sport. We rowed quietly into a little bay with steep cliffs rising sheer out of the water. Zeppo landed; he cautiously watched his opportunity for some time, and then threw in his dynamite cartridge, which forthwith exploded, and the sea glittered with the corpses of small fish. We gathered them in with our appliances-Zeppo's was

E E 
merely a piece of brushwood at the end of a long reed, mine was a hand net fixed on to a forked vine-tendril. With these we soon collected a basketful of small fry, like whitebait, and Zeppo chewed some of them and threw the bits into the sea, promising to return in the evening and kill larger fish with dynamite, which would then have collected to feast on the remains of their lesser brethren.

'Vell, Zeppo, how about your friends in the church?' I now suggested. 'I suppose your fears were groundless?'

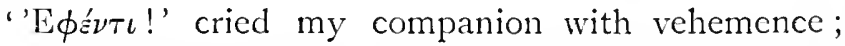
'that night was nearly the death of me; there I sat shivering in a corner of the bema, and listened to their plans. As soon as it was dawn they were going to dress themselves in long black coats, black masks, and horns on their heads. Thus disguised they were going to terrify Andronico or his brother-whoever was tending the flocks-seize as many of their goats as they could, and sail back to Naxos. Meanwhile they lay down to sleep, and I peered out from my retreat, hoping to make my escape and warn Andronico, for no one knew better than I how casily terrified he would be by this device... there is not a goatherd in all the islands who sees more Nereids and hobgoblins than he; but my courage failed me, and I thought it best to remain where I was, and then they might go without observing me. But oh, what a night I spent! No sleep, no rest, nothing but a vague dread of the morning and the coming light. The three men slept for some hours, and I prayed hard to the Panagia, and St. Michael, and all the saints to protect me. At length they awoke, and prepared to put on their disguise. I heard in the distance the tinkling ri the bells on the goats, and I heard, too, Andro- 
nico playing his bagpipe, which sounded prophetically mournful this morning. Yet still I hoped that my danger would soon be over; whilst they were stealing the goats I would hurry to my boat and be off. Imagine my horror, effendi, when one of the men suggested looking behind the tempelon to see if the priest had left anything worth stealing. I crouched down to look as if I was a bundle of clothes. I buried my head in my knees, but all in vain; the fellows saw me, and dragged me out more dead than alive into the body of the church, and sat down to decide on what to do with me. I swore by all that was holy not to betray them-I even swore in my terror to aid them if they would only spare my life; but the wretches merely laughed and kicked me, calling me a spy, a traitor, and horrible names which made my blood run cold. Two of them voted for despatching me at once, saying that "dead men tell no tales," but the third, a more humane man, opposed them, and said that "murdered men brought fellows to the gallows." So they quarrelled for a while, and I_- here Zeppo's voice forsook him, and he fell to trembling again, and found it necessary to light another cigarette.

We felt hungry by this, so suggested that we should land and have our meal, and then I would hear the rest afterwards. Meanwhile I got my valiant companion to spear me with his trident some specimens of the sponges which cover the bottom of the sea here; they are like lumps of coal adhering to the rocks, and oh, how they stink! We felt as if we could never again wash with one ; slimy horrid things, out of the pores of which oozes a putrid-smelling liquid. The sponge-fishers jump on them on the rocks to rid them of this horrid substance, and then cleanse them thoroughly before drying them and 
sending them off to Europe. Zeppo is an excellent hand at spearing sponges with his $\kappa a ́ \mu a \xi$, and sea urchins, too, with a long split reed, which he fixes with great precision into the animal and brings him up. Fishing in Greek waters requires great practice and skill; fly fishing, I thought, would be tame after it.

Armed with sea urchins, whitebait, and a basket of provisions, we put into a little cove, where the rolcanic rocks had formed fantastic arches, and where we were sheltered from the wind. Zeppo lit a fire with sticks, threaded a lot of whitebait on to a bit of reed, and proceeded to fry them on the ashes; but when fried he insisted on dipping them into the sea to cool them and give them a relish, of which we did not approve. We ate, drank, and smoked well, and thus fortified, I thought Zeppo would be better able to continue his story.

'So they did not kill you after all ?' I remarked.

'Kill me, effendi! better that than what they did.'

'Good gracious, Zeppo! I should have thought they could not have treated you worse than to cut your throat.'

'Listen, effendi,' rejoined he with eagerness; 'they bound my hands and feet so that I could not move, and then went out of the church to consult on my fate.' The recollection of the suspense of this moment nearly overcame Zeppo again, but after a moment or two of silence and the formation of another cigarette he recovered himself and continued :-

'They came back very soon, and two of them leisurely put on their horns'-Zeppo shuddered as he recollected this horrible fact- 'and the third, pistol in hand, was left to guard me in the church. "If you utter a sound I will blow your brains out,' he said, and you may 
be sure I was quiet enough. Presently I heard a shriek of wild terror, and I knew well that Andronico had rushed away from the horrible phantasms. Then there came the piteous cry of kids being carried from their mothers by the ruffians down to the boat. They were half an hour away at least, and then, having got as many animals as they could carry, they returned to the church, and I fell to trembling again, believing that now certainly my last moments had come. The diabolical fellows with their horns seemed to me to have come up straight from Hades. I am sure when I see Charon himself I shall feel less terrified. I could not answer them when they asked me from whence I was and how I had come here. I simply indicated where my boat was with a nod of my head, and they had already appropriated my gun. Naturally they were in a hurry to be off, and so they dragged me after them in an agony of terror. They drank a glass of raki all round, and then threw me into the boat. Of course I now felt sure they were going to drown me out at sea, where my body would tell no tales, and I hardly noticed them as they tied my poor little boat behind their caïque. I never saw it again after that day,' he sighed, 'and it was twice as smart a boat as this one,' and he looked disparagingly at the clumsy tub which was riding quietly at the end of the painter a few yards from us.

' On reaching the caĩque they threw me down amongst the kids, and there I lay for a couple of hours, hardly aware that we were sailing rapidly through the water. I thought of all my misdeeds, and I prayed the Panagia to intercede for me. I thought of my old wife, and how she would tear her hair and beat her breast at the lamentations that she would hold to commemorate my decease.' 
This was too much for Zeppo; he wept copiously at the recollection of his peril. Though sorry for the man, I could hardly restrain a smile, but wishing to hear him to the end I refrained, and suggested a temporary diversion in favour of fishing. We gathered up our crumbs and got into the boat, this time directing our course to a deep cave or grotto, up which the sea runs nearly Ioo feet deep into the volcanic rock. The passage was very narrow, only just room for the boat to pass. The colouring was lovely, reminding me of the blue grotto at Capri, and just below the water line the rocks were covered with gaudy sea lichens, red sponges, and corals of rich beauty. Presently we heard a noise from the upper end of the cave, and Zeppo whispered, 'Seals.' He stood in the bows with a dynamite cartridge in his hand ready for execution, but the seals heard us too soon and came snorting and dashing past us before Zeppo had time to ignite the fuse. We went up to the end of the grotto and found their bed on the shingle still warm, and the smell horrible. I could not help thinking how kind that goddess must have been who brought Menelaus and his men 'sweet smelling ambrosia' and put it under their noses when they were lying in ambush in fresh seal-skins.

Zeppo's equilibrium was again restored. So I ventured to question him further about his terrible sail with the kids, in momentary expectation of being thrown overboard.

'It must have been over two hours,' he continued, 'before we ran under a cliff, and they hauled me out of the bottom of the caique, trembling and more scared than ever. They undid my cords and lowered a boat, into which two of them jumped, calling upon me to follow; but, what with being tied so tight and what 
with fear, my legs refused to carry me, and the captain gave me a kick behind, which hurt me very much, but had the effect of sending me into the boat; then they rowed me to shore, and I soon discovered that they were taking me to Strongylo. "By the holy Panagia!" thought I, "what are they going to do with me here? $\mathrm{k} 1 \mathrm{l}$ me and leave my remains on the shore, where, perhaps, nobody will find them for months? I may never get buried at all," I thought, "and my spirit will wander about and drive my wife out of her wits," and here Zeppo again shed tears at the prospect he once had of becoming a ghost.

'But no, this was not their intention. They almost threw me on shore in their hurry to be off, and hurled a loaf of bread after me, saying, as they did so, "Good day, brother! we shall be far enough before anyone comes to release you from Strongylo."

"I sat down on the beach, dazed and bewildered; I saw the cailque unfurl her sails and round the corner of Despotiko, with my boat in tow, and through thankfulness at being rid of my tyrants I did not realise that my position was anything but an enviable one. I was alone on Strongylo, without a boat, without a gun, without any means of communication with a human being. It was winter still; Andronico might not come with his flocks for weeks. I could not swim across to Despotiko-it was too far, and I knew the current was very rapid here. I knew every inch of Strongylo well, and knew that it was exceedingly barren, and at that time of the year scarcely any herbs worth eating grew there. Moreover there is not a mandra or a church on the island, and I vowed there and then to try and get a church erected to the Panagia if she would relieve me from this plight. 
'I don't know how long I sat in this reverie-it might have been hours. But at length I was aroused from it by a downpour of rain; the north wind had given place to a Grego Levante ; ${ }^{1}$ and my only consolation was that my pirate friends would experience great difficulty in getting back to Naxos with their ill-gotten gains. I picked up my loaf and retired to a cave I knew of, where I had often rested when in search of quails at the season of the quail flight-in fact, I had often spent nights in Strongylo. But then it was August, and I knew that my boat was waiting for me on the shore.

'I remained a week on Strongylo without anything of importance occurring; every day I ate a bit of my brcad, and found sea urchins, limpets, and other shell fish amongst the rocks, enough to stave off hunger, and, furthermore, it was the great Forty Days ${ }^{2}$ then, so I could not wish for more. I knew, too, of a spring up on the side of the mountain, so I did not feel any discomfort on this point, and hoped now to be able to support myself till spring came and Andronico should come to my release. Every night when it was dry I lit a fire of brushwood, striking a light with two flintstones on the highest point of Strongylo, hoping to attract attention by it; but I had little hopes of this, as Strongylo is much lowert han Despotiko, and Andronico's mandra was on the other side.

"Well, the days went by slowly enough; some bitterly cold, some wet, and none warm, and, as you see, effendi, I am not so young as I was. Twenty years ago I could have slept all night through in that cave and taken no harm; but now I began to feel suspicious

1 East wind, invariably rainy in Greek islands.

? The Lenten fast. 
pains in my limbs, and shivering fits came over me. No one can ever know how sad I felt at these times. I felt sure my wife would consider that I had been drowned; my boat would be missing, and Andronico would suggest that I had tried to cross over on that stormy night and been lost in the attempt, or else he would tell them that I had fallen a victim to those demons who had scared him so and robbed him of his kids. Each shivering fit left me weaker and more miserable; I felt sure now that I should die before rescue could come. Next day my fever grew worse; I had no bread left; I had not even strength to drag myself to the rocks to look for shell fish; and then followed a time about which my memory is hazy, and about which I would rather not speak.'

Thus Zeppo ended abruptly, and looked terribly solemn. He did not cry this time or light a cigarette; he seemed too much overcome for emotions of any kind. I felt now truly sorry for the man, and had not the heart to question him further on the subject.

'Let us do some more fishing,' I suggested after a long pause, trying to rouse him from his reverie; and mechanically he gathered himself together to prepare his line, a plummet at the end, with three hooks for bait about a foot above one another. With these we caught some red mullet and other brilliant-scaled fish common to these parts, and with the effort Zeppo's spirits somewhat returned: he told me how expert he was in fishing for the scaros, ${ }^{1}$ and described the same method in use now that Oppian sang of in his poem on fishing. ${ }^{2}$ The scaros is a most affectionate fish, and will risk anything to save a female friend. Consequently the expert Zeppo, when

1 Vide p. II 4 .

2 Oppian's 'A $\lambda_{\iota \epsilon} \in \tau \iota k a ́$, iv. 40. 
he can secure a female specimen, dead or alive, of this species, fastens her to a line, and, if dead, artfully bobs her up and down so as to assume the appearance of life. The male scari rush in shoals to the rescue, and Zeppo's companion catches these gallant fish in a net. Zeppo promised me that next time he got hold of a female scaros he would preserve her for my special benefit, but the time never came. In the mysteries of tunny fishing, as carried on in Greece, Zeppo likewise enlightened me. May is the month for this sport, hence they are called

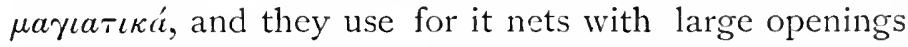
and thick string. They choose a bay, and a convenient promontory, from a post on which they fasten their nets while they row out to a rock in the sea, leave a man on this rock, and return to shore by a roundabout route, carrying a string with them, by which they can pull in their net as soon as the man on the rock announces the arrival of the fish ; this is the plan alluded to by Aristotle $(\pi \varepsilon \rho i \zeta \omega \omega \nu)$. If the market is overstocked they drive the fish into a creek by stones, and fasten up this creek with brambles, where they remain ten or fifteen days, till they are wanted.

It was too late now to go and try the dynamite again, so Zeppo just set his nets for the morrow-long ones fastened on to corks to float them, and gourds to mark their whereabouts, and we returned home.

That very evening I walked on quickly whilst Zeppo was attending to his boat, and found his wife alone. She told me the sequel to his story: delirium had come on with the fever-fearful visions of horrid monsters and horrrible deaths haunted his dreams. How long this lasted no one knew, but Andronico found him one day, more dead than alive, and brought him home to his 
sorrowing wife, who had, as she told me, indulged in the poignant grief of a Greek widow.

Mrs. Zeppo had gone through a lamentation ceremony in honour of her husband's memory, a fearful, heartrending $\dot{\varepsilon} \xi o \delta i o s s \rho \hat{\eta} \nu o s,{ }^{1}$ and it had all been in vain.

1 Vide p. 2 I2. 


\section{CHAPTER XVII.}

KYTHNOS (THERMIÀ).

As we entered the bay of Hagia Eirene of Thermia we thought we had never visited a more dreary, inhospitable shore. Not even had we the mountains jutting boldly into the sca, as they do in all the other Cyclades, to relieve Thermià from its ugliness. It is treeless, too, and flat, except at the northern point. As our boat drew near the shore we witnessed a touching scene-the departure of a young Kythniote to try his fortunes in the outer world. His relatives were there to bid him farewell, giving way to those extravagances of gricf so dear to the heart of a Greek; not until the last whistle of the departing steamer did he tear himself away, and was rowed, amidst sobs and groans, to the vessel. They explained to us what a solemn affair departure for foreign parts is considered here in Kythnos: quite a ceremony is gone through. All his friends and relatives meet to bid him farewell, and as he crosses the threshold of his home one of the household pours out of a glass a libation of water to the gods, which is supposed to ensure abundance and success. Then the farewells begin: the least intimate embrace him at his door, others accompany him part of the way, only his near relatives go all the way to the harbour, and none of them wish him a spcedy return, for it would be a bad omen. 
Some of these long absences ( $\zeta \omega \nu \tau a \nu \grave{a} \dot{a} \pi o \chi \omega \rho i ́ \sigma \mu a \tau a)$ on the part of the males are made very trying for the women left behind ; it is considered for them as a season of mourning: all the smart antimacassars are removed from the sofas, all ornaments must be put away, and the wife is expected to pass the time in genuine widowhood until her husband's return. She must not dance, she must not be seen at feasts, and her visits must be restricted to her nearest relatives. And the return

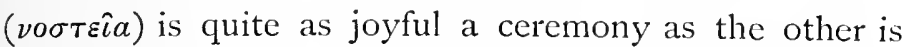
mournful, though, to the detriment of Kythnos, it is of far rarer occurrence. On the first days after the wanderer's return friends and relatives pour in with presents of food and congratulations, and the wife can indulge once more in the pomps and vanities of the world.

'If your eyes water,' say the Kythniotes, 'you will see a friend from afar; if your left hand itches it will be a letter ; if the right, money,' and, true Greeks as they are, the itching of the right hand is by far the favourite symptom. There is a wretched wineshop down at the port of Hagia Eirene, where we waited till our mules could come from Messarià, the capital of our new realm. It was a dirty, repulsive hole, kept by a halfclad old woman and her daughter, who looked at us with greedy eyes, as if their right hands had been itching when the steamer came in, and that we were to fulfil the prophecy. As we relieved our hunger with some cold fish and bad wine, something really did itch with a vengeance, for the daughter was called upon to search her mother's matted hair ; and she searched, too, with evident success -an appetising sight for us! Yet even in this abode of filth a structure called a bed in one corner had a beautiful bit of old Greek lace as an ornament to its sheet.

As the mules were long in coming we took a boat 
and went to visit the bathing establishment of Thermia, from which the modern name of the island is derived, though since the revival of Hellenism it has become the fashion to call it $\mathrm{Ky}$ thnos, as of old. It is a large, uninteresting bathhouse, German in character, for it was built during King Otho's reign under the direction of a German doctor ; it contains the hot springs, and offers accommodation for over a hundred guests, who come here in the summer time for the baths. In remote antiquity Kythnos is never alluded to as a bath resort, and never rivalled Edipsus, though it is just as easy of access, and the waters are stronger. It is probable that the source was unknown to the ancients, and that the waters first disclosed themselves after an eruption of Mount Sorus, a now extinct volcanic hole on the hill behind. Kythniote shepherds say that when they lose a beast down this hole it will be cast out again close to the baths. There are traces of Roman remains, however, and tombs near the baths, and Rome had a good deal to say to $\mathrm{K}_{y}$ thnos in the days when the false Nero set himself up here and overran the Egcan Sca with his piracies. As far back as I 42 A.D. the island is mentioned as Thermià, so that the hot baths are now of considerable antiquity.

But not till I 782 did they build a bathing house here, and this was done by the instrumentality of the great Marrojenes of Paros, who was hospodar of Wallachia. But the people of the island flatly refused to use the waters; they were far too superstitious, and said that the warm springs were haunted by Nereids, and that the devils of Hades worked below. Even now a Kythniote peasant is afraid of them, and tells you that Charon has his garden below here, where he plants young men and women and small children instead of flowers; but yet a 
Kythniote has great respect for his baths and the new establishment, for they bring money and strangers to his island.

It is certainly a dreary spot to go to for a cure; not a tree near, and a hideous waste of sand, impregnated with mineral water, between the bathhouse and the sea; rheumatism for life would be preferable to a month of the burning summer spent here.

The town of Messarià, as its name implics, is in the middle of the island: it is a long, narrow, uninteresting white place, running along a low ridge, with two or three windmills behind it to break the monotony of the view. The inhabitants looked uninteresting: they wore none of those pretty costumes which Ross saw forty years ago, for they told me that a Jew had visited Kythnos two or three years ago, and had bought up every costume and every scrap of embroidery in the place.

'Then does no one wear the costumes now ?' I asked of the demarch; whereat he consulted his wife, and replied that the old woman up at one of the mills, who was the last to wear the old dress, had died a few months ago, but that his brother, the doctor, had a doll for his children, dressed in detail as a Kythniote; and this doll was brought me for inspection. The costume must have been chiefly remarkable for its puffed out sleeves, short skirt, and trousers, fastened like knickerbockers under the knees, reminding one of a divided skirt. I was grateful for seeing this doll, and annoyed at the Jew; but, though he could buy up their costumes, he could not buy their customs, which remain firmly rooted in Kythnos, despite the numerous bath guests and the steamer which comes from Athens once a fortnight, and despite our host, Demarch Bastas, who is one of those reforming demarchs, like our host at Pholygandros. Hc 
had been at Alexandria, where he made money, and now recognises how far behind the rest of the world his island is in civilisation.

I never had so much difficulty in going through the necessary compliments of admiration as when the demarch took us over his town. Nothing will grow near it, for it is exposed to every wind, having no sheltering mountains around it; and I could not divine why such a spot could ever have been chosen for a town until I heard the legend that on the fall of the old medireval town into the hands of the Turks an archon had fled towards the south, and his horse, wearied with the rapidity of his flight, stumbled down here: so the archon recognised it as his duty to build on this spot, and gather round the Church of the Holy Trinity the nucleus of a new town.

Kythnos offers a good illustration of the vicissitudes of a one-citied island. First, there are the ruins of the old Grecian town in a charming nook on the western coast ; this was inhabited in the Roman days, but deserted before the introduction of Christianity. Then there is the severe Frankish town, built on a beetling cliff to the north of the island, where, says the local tradition, 'on Easter Day, three hundred years ago, the Turks took it from the Franks, and a great slaughter took place, so that the sea was red, and the redness thereof reached even to Zea (Keos).' Close by they still point out a red spot on the rocks, which, they say, was made by this dread slaughter; and if you ask your muleteer he will sing you the Thermiote's favourite song about the mighty robber who placed a chain in the sea from Thermià to Zea, and took many ships in his toils, so that his riches were innumerable. The conclusion of this saga, relating the capture of the fortress by the Turks, is quite Homeric in style, and runs as follows :- 
Twelve years they fought, and fourteen more delayed

Before the walls of Thermià's tower.

One day a Turk, a little Turkish maid,

Dressed as a widow, all in garments black,

Dragged up the hill her weary steps,

And made as though her time was nigh

That she should be delivered of a child.

'Open the gate,' she cried ; 'open in haste !'

And the watchman's daughter, conscious of her plight,

Threw open wide the portal, and, behold,

A thousand men rushed in, ready for blood !

So Thermià's history is chiefly written in her ruins and her sagas. Messarià was probably founded by one of the Frankish lords in the sixteenth century, the Gozzadini being the family who ruled it as an appanage of the Naxiote duchy; and over the Church of St. Sabbas we find the initials of one of that lordly house.

Another episode in the history of Thermià, now told only by tradition, is the colonisation of the island by Cretans during the war which raged for the possession of Crete between Turks and Venetians. A legend says that another church at Messarià was built by an honest Kythniote under the following circumstances. A Cretan refugee entrusted a lot of money to this man during his absence, but he never returned; so the Kythniote thought the best thing he could do with the money was to build the Church of the Transfiguration.

In another church we saw 'the Virgin of Athens,' which name struck us with reminiscences of Byron; but this virgin, we are told, made her escape from that city when it fell into the hands of the Turks. She took to the sea and was washed up at Kythnos, and she is nought but a bit of old painted wood, which made me think of the sacred Goava of antiquity, and how they used to be miraculously discovered in the sea, in trees, and in the 
earth, just like the pictures of the Virgin are found by the orthodox Church.

It was the first of the Greek March; a bright, warm day enough; and as we walked about the torn we saw a lot of youngsters busily engaged in going from house to house singing and begging. The acolytes from the church had got hold of the cross, which they were carrying corered with flowers. I got the words from a friend, and though they are incoherent they are interesting.

- We the three, the four, and twenty-four others have gone round the city-the city-the metropolis. March, my brave March, and dread April, too! Cast figs in the handkerchief and grapes in the basket. Hail, Adam! Hail, Chastity! Hail, honoured Cross! O joy of the apostles and wisdom of God! To-day and to-morrow and all the week, as the cross is adorned with flowers may the birds be adorned. Away, fleas, rats! away to the hills and mountains! May your cocoons be many, and tight and powerful and heavy with silk!'

This is no more nor less than a remnant of the ancient swallow festival $(\chi \varepsilon \lambda \iota \delta o ́ \nu \iota \sigma \mu a)$. In Macedonia, on March I, a wooden swallow is made and encircled in leaves and put on a post, to be carried round, and the boys sing, 'The swallow has come across the dark sea,' just as in ancient days at the swallow feasts, revellers used to go round and collect 'little gifts for the swallow' (Athenæus). Now in Thermià, as in Macedonia, eggs are usually given to the children in return for their song. Sometimes, too, they ask a riddle on this occasion: 'On the top like a frying pan, below like cotton, behind like scissors.' Answer: 'A swallow.'

Many similar customs are carried on nowadays on May I. They go round and sing- 
May has come, and bids me say,

'Wintry days have fled away.'

And on May I they hang out garlands of flowers from their windows and balconies, also bunches of green ears of corn-a sort of dim relic of a feast of Demeter, and recalling the old custom of ipoá $\nu \iota a$, when at springtide the women of the Peloponnese dressed themselves in flowers and held festival.

On Good Friday and Easter they go round and sing low dirges about Lazarus' death and Hades, receiving presents of food from each house at which they sing.

On New Year's Eve the Thermiotes prepare cakes made of roasted corn mixed with honey and cheese;

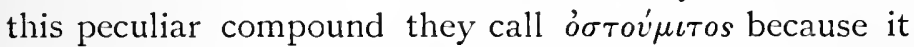
is made to the accompaniment of drums ( $\sigma \tau o v \mu \pi a \nu i \zeta \omega$, $\tau u \mu \pi a \nu(\zeta \omega)$. They have the Kallanda, ${ }^{1}$ too, as elsewhere ; and to the children who sing them, and who throw in rose leaves at the doors as they go by, each householder feels in duty bound to present a 'love gift.'

To-day was, as I have said, March I, a day on which all good mothers insist on the children putting rings on their fingers-perhaps a bit of coral or some glass beads-and to this are tied two coloured threads as a protection against fevers; they wear them till Easter Day, when they are burnt in a fire lighted at the church door.

Messarià has been in its day a most unwholesome place; there are inhabitants alive now who well remember the fearful plague which carried off seven hundred people at the time of the revolution, which, out of a population of two to three thousand, is an alarming percentage; and they call this plague still 'the plague of Loutso' -why I could not find out-' when the keys remained in

1 Vide p. 129. 
the doors,' alluding to the whole families which were swept away and whose houses were left desolate. Many fled to the hills at the northern end of the island, and returned to find their houses looted by pirates, and desolate.

There are inhabitants, too, who remember when Kythnos was not so bare and desolate as it is now. The foregoing children's song on March I alluded to silkworms, which were much cultivated here formerly; but one day a disease got amongst the worms, and the inhabitants cut down the mulberry trees for fuel. Olive groves also existed here, but the pirates and the Turks cut them down, for flat Thermià had not the powers of resistance that mountainous Naxos and Andros possessed. So now it is a poor, wretched-looking place, and our host's brother, the doctor who accompanied us in our walk, told us how subject they were to diseases, and the difficulties he had to contend with in combating the numerous superstitions attending them.

'Children's ailments,' he said, 'are more especially subject to this, and superstitious mothers, in spite of all I can say or do, insist on treating them in their own way. For sore mouths, called aftì (thrush), for example, the treatment is as follows. The mother shows the sore to the evening stars, spits on it, and says, "This evening stars and aftà, to-morrow no stars and no aftà." For this ailment also it is considered a good thing to get a sailor who has been three times round Cape Malea to spit three times on the poor child's sore.'

Another favourite remedy for a sickly child is to expose it to the first new moon, and for the mother to say, 'May you have glory for what you will do, O new moon! I have an empty flask; fill it or take it from me altogether.' There is something poetically pathetic 
in this last remedy. Another one, of a similar nature, which the doctor told me, somewhat reminded me of the exposure of children at Melos : ${ }^{1}$ the mother takes her child to a hole in a rock about half an hour from Messarià, and passes it naked through this holc, being careful to put on new garments and to throw away the old ones. On a Saturday-baking day in this island--if a mother has a child in convulsions it is considered a good plan for her to climb to the top of the oven and call out three times, 'The wolf has taken my child!' and someone who passes by will answer, 'If he has taken it he will bring it back.'

'It does not so much matter about the children,' continued the doctor, 'if they do die without my being called in, we just say nothing about it. But it is quite a different affair if we catch them neglecting a fever, and trusting to the burning of a reed in the fire on St. John's Day-because they believe that fevers came into the world when St. John's head was cut off-we are obliged to have them up and punish them for their folly.'

'They have queer ideas about consumption, too, and, like the Andriotes, ${ }^{2}$ attribute it to evil spirits, called the Erinyes, which eat up the vitals of the patient, and which will seize on anyone they can when the person dies; so they are careful to prevent any young person from entering the room, and open a hole in the roof over the dead man's head out of which the spirits can escape.

'This does not matter so much ; it pleases them and hurts nobody,' concluded the doctor laughing.

The Thermiotes are not only superstitious, they are an intensely religious race. No vineyard should be planted on a Friday, for this was the day of the Crucifixion, and on St. John the Baptist's Day, in June, they
1 Vide p. 64.
2 Vide p. 292. 
stop work and sprinkle the fig trees with dust, for in June the figs are subject to destructive insects and scabs;

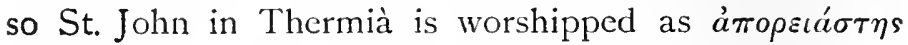
or $\psi \omega \omega \iota$ ép $\eta s$. You should never do any work if you can help it on the days immediately preceding the full moon, but for grafting, planting, cutting trees, bleaching clothes those days are the best which follow the full moon, and for killing pigs, too, for then the skin is supposed to be in the most perfect condition.

A serpent dwelling in a house is considered harmless,

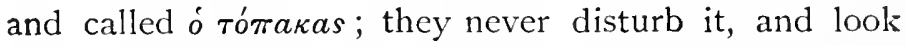
upon it as the genius loci. This recalls to one what Theophrastus tells us-that in his days if a serpent was found in a house an altar was erected to it, and it was looked upon as a sign of happiness.

Our quarters with Demarch Bastas were everything that could be desired, for we had an excellent bed and excellent board. The wine of Kythnos is good, but it has that peculiarity common enough on the mainland, but which we met here for the first time in the islands, it is resinated, that is to say, the barrels in which the wine is kept are covered inside with resin to preserve it, and this gives a very strong flavour of varnish to the beverage. The Greeks love this resinated wine--it acts as a tonic -and in hot weather is very refreshing; but foreigners, as a rule, are rather doubtful about it at first, though I do not think the flavour is worse than beer must be when you first drink it. The custom is by no means a modern one; Plutarch ('Quest. Nat.' x.) tells us how the ancients put sea water into their wine to give it a flavour, and he also tells us that the casks were smeared inside with pitch, and that the Eubœans actually did put resin into their wine to flavour it.

Another speciality of Thermià is its cheese, so 
delicious that one does not wonder at Epicurus, who said that as often as he wished to sup most luxuriously he put Kythniote cheese on the table ('Laertus,' $x .6$ ). It is a loose and crumbling cheese, of which you get a large helping given you on a plate ; it never sets, nor is it put into those skins which compress and spoil other Greek cheeses. The curdled milk, unboiled, is slightly salted, and then put into earthenware jars and pressed until all the whey is squeezed out. Pliny tells us that it was a wild flower which grew in Kythnos which gave the delicious flavour to the cheese. I could not discover anything about it there, though the Kythniotes affirm that it is their pasturage which makes the cheese so good, just as at Ios the excellence of the mysethra was attributed to the same cause. ${ }^{1}$ At all events we enjoyed our cheese, and thought it worth going to Kythnos to eat, as Epicurus would say.

They have a cheese Sunday in Lent at Kythnos, which is a general festival : jovial parties gather together to laugh and sing, and the children carry about an image, covered with grass, which they call Macaroni, because, say they, he has come to fetch some of that commodity. Accordingly every householder gives them some. It is deemed very unlucky to sneeze at the cheese Sunday banquet; anyone who does must tear his coat to avert disaster. Greeks, in common with other nationalities, regard sneezing with superstition; if you are a layman they wish you good health, if you are a priest they say 'safety'; why this distinction I could not find out.

Next day we mounted our mules and went to visit the ruins of the old town-Bryocastro, as it is called; 'Jews' Camp,' as many speculative etymologists read the 
word: but why 'Eßpaîos should become Bpv́os I am at a loss to imagine; surely it is more simple to call it 'Brigands' Camp,' for the last people who inhabited it were Roman brigands, Phrygians, or Bev́rzs, as the Greeks called them, and the gamma $(\gamma)$ goes for nothing in modern Greek; for except the Jew who bought up the Thermiote costumes two years ago I question if a Hebrew ever set foot on the island. Greeks and Jews never did get on well together, the former apologising for even the mention of so despicable a creature as the latter.

Bryocastro is an hour's ride from the town, and on our way to it we passed through really a lovely valleya cleft full of green almond trees and verdure. Here all the washerwomen of Thermià assemble to wash their linen, and the kind Demarch Bastas has built them a shed to protect them from the inclemencies of the weather. Commanding this strip of fertility are the ruins of an ancient Hellcnic tower, built, say the people, by an ancient king of Thermià to protect the washerwomen from the pirates; but it is just another instance of the numerous watchtowers in the islands placed to protect a fertile valley, as well as the only stream near the town.

The old town of Kythnos had a charming position, commanding two landlocked bays and possessing an acropolis from which an extensive view over the distant Peloponnese, Hydra, and the Saronic Gulf can be gained. On this acropolis are traces of a temple, an altar, and a reservoir, and within the precincts of the town are altars, temples, and watercourses in abundance. This acropolis is built of extraordinarily huge stones, and is known by the inhabitants as the Dragon's House. The superstitious always put down these Cyclopean walls to the work of dragons, who with their great strength can tear 
up trees and hurl huge rocks, like Polyphemus of old; in fact, in one of the fables given by Von Halm the dramatis personce are a dragon, who corresponds to Polyphemus, and Spanos, a wily traveller, who conquers the silly dragon, and resembles Ulysses. Out of these modern fables parallels can be found to cunning Ulysses, much struggling Hercules, the Homeric Cyclops, and a vast number of mythical personages.

Down by a promontory over against a little island which was once connected to the mainland by a pier are traces of the agora, and in the sand below is a headless half-buried statue, of Roman work, seated on a throne. I could not help wondering if this statue had ever been intended for the false Nero who ruled here for a time: He was a slave from Pontus, who so resembled Nero that he ventured to set up as the emperor, on the supposition that he had escaped death, and M. Rénan thinks St. John had this false Nero in his eye as the Antichrist of the Apocalypse. From this stronghold in Kythnos he must have been a fearful scourge to the Egean Sea, so much so that the centurion Sisenna on his way from Syria to Rome was nearly captured by him. Galba it was who sent an armament, under Calpurnius, to Kythnos, and put an end to this adventurer's career.

The little island in the bay is covered with traces of ruins, and, as at Kimolos, is called by the natives $\Delta a \sigma \kappa a \lambda \varepsilon i{ }^{1}{ }^{1}$ Hither the superstitious Kythniotes still bring the bones of one of those dread wandering spirits, for a Kythniote believes firmly in Broukolakes, dead men, who for their crimes haunt the world and commit horrors after death. The priest opens the tomb of such an one on a Friday, being the only day of the week in which the dead man is supposed to remain quiet in his tomb, he 
then puts the bones into a sack and carries them to this lonely island and turns them out of the sack. The idea is that a ghost cannot cross water.

Above the harbour we visited three caves, ten feet long and ten feet high, cut out of the rock, and communicating with one another by two doors at the inner end. They are carefully covered with cement, and from the traces of a watercourse, which has been conducted down into them, we may argue that they were a peculiar kind of reservoir in use during the Roman epoch. Except for the actual walls all the remains of Bryocastro point to the Roman period; it appears to have been looked upon then as a stong military centre, and when the Rhodians and Attalus fought against Philip V. Kythnos did not surrender, but remained faithful to Philip, and even resisted the flcet which had captured Andros.

Another expedition which we made at Thermià was to the town of the second epoch, the Frankish fortress on the northern headland; it is close to a disused monastery dedicated to St. George, where the Thermiotes go for their annual festival. They now call the spot 'the fortress of beauty,' and a more splendid situation for a fortress it is impossible to find. It crowns a rock rising 500 feet out of the sea, and is approached from the land side by only a narrow tongue of land. There is still the wall standing, which is entered by a low doorway, and inside the old churches and houses are in many cases in good preservation; but it is a desolate, weird place, and full of terror to the inhabitants.

Here in I 82 I the people of Messarià took refuge from the Turks, in spite of the dread they have of the fearful demons $(\sigma \tau o \iota \chi \varepsilon \hat{\imath} a)$ which haunt it - giants with black faces, evil-doing spirits, man-eating, like the Homeric Cyclops, 
who guard hidden treasures of Venetian florins which have been buried in the ruins.

After leaving this spot we came across a shepherd's hut- $\tau \grave{a} \kappa \varepsilon \dot{\varepsilon} \lambda \iota a$, as they call them in Kythnos. Each proprietor has one on his property, wherc he stores his produce and lives during the harvest time. The owner was away just now, tending his flocks; but he had left his door so closed that by pulling a string a bolt inside was drawn, and we could go in. Here in the middle were two bags full of curd hanging from the ceiling, the whey was running off into two wooden trenchers, and above the bags were placed two large bushes of brushwood to keep off the rats, and in a corner a caldron full of whey was simmering over some charcoal ashes to make mysethra. We drank some whey and wondered at the owner's confidence in thus leaving to the public the produce of his flock.

Beyond these simple materials for "making cheese there was no sign of anything in the hut, no domestic comfort whatsoever saving a large amphora full of water, with the usual bit of sponge stuck in for a stopper ; there was not even a pretence at a bed, the shepherd must just spread his skin cloak on the mud floor and sleep on that.

South of Messaria there is another village, called Silakka, about an hour's ride from the capital, and on the road we passed by no less than four ruined monasteries, the outer walls of which were brown and crumbling, whilst inside the whitewashed church, still taken care of to a certain extent, peeps up and seems to reproach the sacrilege around it. Silakka is prettily situated on either side of a cleft watered by a brook; it is far prettier than the capital: the houses climb one above another, and there is a fair-sized hill behind it, which gives an air of importance to the place. 
As we passed by the café one of our muleteers muttered the talismanic word 'Demarch!' and forthwith this functionary stalked out of the café, cast a hurried glance at us, and without a word walked on in front and lead us to his guest-room up a staircase; having done this he turned round and formally bade us welcome. Of course this was followed almost immediatcly by coffee, mastic, cigarettes, and questions-for it is a point of honour amongst these remote people to ask no questions until the stranger has partaken of some refreshmentquite after the style of ancient days, when after the feast was over the traveller was called upon to tell his tale.

Silakka dates only from the days when pirates infested Thermià, and it owes its existence to a large cave which is almost in the village, and in which in times of distress the inhabitants took refuge. It is the one sight of the place, and thither, after a seasonable rest, we were conducted by the demarch and his son and most of the villagers. Of late years the cave has been used for a public rubbish heap, and through this dusthole of ages we had to creep past old boots, dogs' skeletons, broken crockery, and the like. Aided by the light of many candles which we and the demarch's son and five officious little urchins carried, we got in at last: it is a curious cave, full of glorious stalactites. As we went on we came across narrow passages, thirty feet long, through which we could hardly squeeze ourselves; but our clothes by this time were as those of the Gibeonites, and could not receive any further damage There are various chambers in the cave, large vaulted ones with firm floors; in one of these the inhabitants used to dance on the Friday after Easter, but the accumulation of mud and rubbish has obliged them to abandon this pastime. The cave is still the object of great vencration, 
and only for forty days after Easter is it safe to enter it, when the Nereids' power is supposed to be dormant.

I was not sorry for this, as otherwise our retinue would have been unpleasantly large. The demarch's son professed to believe in norie of these things, and the five urchins were full of the spirit of adventure: they told us what fun they had here during those forty days after Easter; how they and all the children of Silakka assemble in the cave to play, taking with them large bundles of brushwood for kindling a fire; and then four or five of them get into a hole, which they pointed out to us, and the others wall them in and pretend they are Nereids. All the stalactites have names-not very beautiful, for the most part — and the demarch's son, with a bashful air, tried to gloss them over for our benefit; but the five urchins would not hear his amendments, and always corrected him.

Though the Jew already mentioned bought up all the old costumes of Thermià, the women dress oddly enough, covering their faces so that only their eyes appear, and as they stand tending their goats by the roadside they look peculiarly Turkish ; it is curious to see the general tendency in these islands for the women to cover their faces ; in Amorgos they do it, too, only there they do not wear the projecting handkerchief as in Kythnos; but in these islands the Turkish influence has left no other trace, for anything Turkish would have been scorned; this custom is certainly not from an Italian source. I am inclined to look upon it as a survival of antiquity, when the face was covered with a veil. Homer represents Penelope as followed by two of her women, her face covered with a magnificent veil. Does it not arise from .the old idea that women should not be seen? An Italian traveller, Foscarini, in the middle ages describes how 
Greek women never went out of doors in broad daylight, and were never seen at public assemblies. Michael Psello, the best authority on Byzantine customs in the eleventh century, tells us how his mother wore a veil to hideher face from the gaze of men, and how the officials in attendance on the Empresses Zoe and Theodora never raised their eyes from the ground out of respect to the sex of their rulers. These veils in Thermià are worn by the women winter and summer when out of doors, and, as they say, it is impossible to recognise even your sister when she is thus dressed. In Thermià the peasants still, as in ancient times, make clothes out of the flaky asbestos; specimens of these garments, as made by the ancients, are to be seen in the British Museum.

We met with our usual difficulties in getting away from Kythnos, aggravated by the fact that this island possesses only two caïques, one of which was now absent at Syra. Over night the demarch made an arrangement for us with the captain $\left(\kappa a i \xi_{l}\right)$ of the boat, and when the morning came, and the wind blew fair for carrying us to Keos, we never for a moment feared a delay. But at the appointed hour the captain never turned up, and, to our dismay, we learnt that he was in the café and refused to go. Our host was obviously angry; he accompanied me to the café, and there poured on the captain's head all manner of abuse, calling him a 'burnt man,' that is to say, a fool, ' a peacock,' 'no man at all,' ' horns,' \&c. But the captain was impervious to abuse, and sat stolidly bubbling away at his narghili.

'It is March,' he said at length, as if that was sufficient to convince us of the perils we wished to undertake-and perhaps to a Greek this would have been a conclusive argument, for what Greek is there who does. not dread to go to sea in March? March, the fickle swain 
who dwells with a lovely but crossgrained mistress, and is delighted at her beauty, but grieves at her anger; March, who has deceived his eleven brothers and got a beating for so doing; March who was so angry with an old woman for thinking he was a summer month that he borrowed a day from his brother February and froze her and her flocks to death-all these allegories, and more besides, a Greek will tell you to illustrate the fickleness of this dread month. But, being English, I professed a contempt for March, and added to the other names levelled against the captain by calling him an old woman, whereupon he confided to us that he had seen a cat that morning licking herself with her face turned towards the north-a sure sign that the wind will soon blow from that dangerous quarter; and furthermore he had scen a hen flap her wings - a sure sign of a tempest.

All we could do was to laugh at the mariner's cowardice; he was determined not to go, and to show his determination he ordered his narghiliti to be filled again. 'That captain is a well-known coward,' apologised the demarch, but afterwards we learnt that he was afraid of the wind, which was fair and southerly, preventing his return from Keos; so for once we were troubled by the wind being too fair ; we had had plenty of persistent head winds and persistent calms. This was, at all events, a new experience.

Later on in the day we heard that a strange caique was in the harbour discharging a cargo of lime, so we transported ourselves, bag and baggage, down to the harbour, and soon entered into a contract to start next morning at break of day for Keos. It was a weary, uncomfortable delay, but the day and the night passed somehow, the latter in the bathhouse; and ere the sun had risen we had left Kythnos far behind. 


\section{CHAPTER XVIII.}

$\operatorname{KEOS}(\mathrm{ZEA})$.

OF the smaller islands of the Cycladic group Keos has played the most important rôle: its ancient name was Keos, its mediaval one Izia, and now the inhabitants call it Kèos, or Zeà, as fancy takes them. It is blessed with a fine harbour, and is the nearest of the Cyclades to Athens, consequently in ancient days it was in constant communication with the centre of learning. It produced the red earth ( $\mu$ i $\lambda$ tos) from which the Athenians made paint; it had four considerable cities; it was the birthplace of Simonides, the poet, and Aristotle wrote a book on its constitution, which has unfortunately been lost. Here, too, all old people who reached the age of seventy quietly took a dose of hemlock, and did away with themselves, thereby relieving the State and their relations of any further trouble. So no wonder Keos won for itself a name in ancient times.

In later times Keos was a well-known place. When the Piræus was nothing but a heap of ruins all the Turkish Government ships, and merchant ships which had to do with Greece, harboured in Keos; and when a ship was wanted at Athens they lighted a beacon on the spurs of Hymettus, and she came up the Saronic Gulf; all nations consequently had consuls there. Before steam was invented, and Syra sprang up, Keos was the em- 
porium of the Cyclades. Catherine of Russia recognised its importance when she put Katzoni of Keos at the head of the Greek corsairs who ravaged Turkey at the close of last century, and made Keos their trysting place; but when the Chiote refugees would have made their home at Keos, the Keotes refused the offer, and the commercial centre was transferred to Syra-not that the Keotes are much to be pitied for this loss of fortune: they have a very beautiful island, productive of far more than is needed for home consumption, and they are not an ambitious race. With complacency they watch from their town the steamers plying east and west without a regret that they do not stop at Keos; they cultivate their oaks and their fields, and retain far more of the old world life than the busy Syriotes, for only a weekly steamer touches here and a few caïques which traffic in acorns.

Scarcely had we landed, and realised that we were on the island, than we were introduced to a pleasant old man, a celebrity in Keos, for he knows every inch thereof: he rejoices in the name of Barba ${ }^{1}$ Manthos.

Barba Manthos, if he had lived in ancient days, would have taken the necessary dose of hemlock some years before; and I must say I am glad he was spared, for a more able or intelligent cicerone could not be found. And when he is numbered with his fathers there is no one in Keos to take his place, no one who knows one stone from another. The Custom House officer sent for us before we had been ten minutes on shore, and it was with some trepidation that we went to his house, for our caïque had dropped us on Keos and set sail again without the necessary papers-and who was to know from

1 Barba being a familiar term, applied to old men in the islands, borrowed from the Venetian patois $b a r b a$, an uncle. 
what country we had come?-however, it was only to beg us to share with him his midday meal, which was highly acceptable, seeing that we had left Thermia at 5 A.M., and had breakfasted off water, bacon, and stale bread.

The port of Keos, Livadhi by name, is a busy little place, and larger than most island ports, for here the richer inhabitants have houses where they reside in summer for sea-bathing; and the whole place was full of sacks of acorns when we arrived, so that we were made acquainted at once with the staple trade of the island, which boasts of a million and a half oak trees growing crer all but the northern slopes. The poorest Keote possesses a few oak trees, and from August to October the oak harvest keeps them all employed. The acorns are huge things, as big as eggs, astonishing to our eyes; but it is the cup only that they export, the acorns are, as with us, eaten by the pigs. Many of the oals of Keos are centuries old-great, gnarled things that remind one of the pride of English parks-but why Keos should be the only one of the Cyclades where they grow and are looked upon as an industry I could not discover. The abundance of oaks has caused an absence of olives in Keos, so the people eat more meat than elsewhere and are consequently a braver, hardier race than their neighbours-at least they say so themselves, and add, with pride, that Keos was the first island to assist Athens in the Median Wars, and was the first of the Cyclades to send troops to assist in the revolution in $\mathrm{I} 82 \mathrm{I}$. I did not like to suggest that their proximity to the mainland might have something to say to this.

Barba Manthos, stick in hand, at once took possession of us. 'You must come with me over the ruins of Koressia first,' he said, and as Koressia was situated on a spur of 
hills just over the port I deemed his advice seasonable, and we went. ${ }^{1}$

With the exception of the roads in Syra, no ascent is so good as the one which joins the town of Keos to its port. You proceed for about a mile along the dry bed of a torrent, the ancient Eliskos, very pleasant to walk upon when there has been no rain for some days, but after a heary downpour it is often impassable; then you commence the ascent along a well-paved road which is built on the ancient foundation, I was told, for Keos is full of traces of ancient roadways. Barba Manthos said he remembered when the ancient fortifications along this road were visible, but forty years ago the Keotes became energetic, made themselves a new road, and obliterated all traces of the old one.

After winding up the hillside for about half an hour the curious town of Keos burst on our riew : it is like a white and yellow plaister on the side of the lofty mountain which encircles it; the houses climbing one above another like the steps of a gigantic ladder. On a spur which sticks out from the mountain in the middle of the town, and which is connected with the mountain by a col covered with cottages, are built some of the finest houses ; and here was the ancient Greek town of Ioulis as well as the mediaval town.

The Chora of Keos commands a most enchanting view, being high up and facing the north; to the northeast is the snowy range of Eubœa, with Mounts Ocha and Delphis, which seem to belong to the mainland and to join with the range of Parnassos, which forms a background to the more humble mountains of Attica, Pentelicus, and Hymettus. To this spot fled the high priest of Athens, Michael Akominatos, when Athens fell

1 Vide note. 
into the hands of the Franks, for there was a monastery here, where the public school now is, for here he could live in peace and still look upon his beloved Athens though banished from it for ever.

Our letter of introduction here was for the eparch; this caused some little jealousy between him and the demarch ; consequently between the two we nearly came to grief. But we eventually found ourselves in possession of a little house belonging to the muleteer who had brought up our luggage from the harbour ; and really we preferred it, for the man and his wife were simple-minded, pleasant folk, and we had not constantly to be on our best behaviour and taxing our conversational powers.

Keos is the queerest place imaginable: the flat roof of the house beneath us fitted close up to ours, and this seemed to be almost the universal custom, so that most of the houses are entered by the roof of the house in front. Everybody walks on the roofs as being preferable to the dirty, dark alleys, arched over for the most part, which are given up to pigs. That evening I went for quite a long walk and never left the roofs, going from one to another by little staircases or little bridges as the case might be; but next morning when we found our neighbours staring in at our window we thought the advantages were rather counteracted by publicity.

Close to their town the Keotes have one of the most charming promenades in the world-a broadish level walk skirting the hillside and leading to the celebrated lion. The outline of the white and yellow town against the blue sea and distant mountains is perfectly enchanting, and there are a few trees which relieve the monotony so common among the Cyclades IVindmills are dotted along the heights; above and beneath your feet is a rich gorge, bright with the tender green of almond trees. 
The lion of Keos is the most interesting sight on the island. It reposes on the hillside; propped up by stones to prevent its further slipping. It is made of grey granite, and from nose to tail is nine yards and a half long. It is in an attitude of repose, and though much worn by age the features are all distinct-eyes, mouth, and mane. Owing to recent excavations we now know that it has slipped from its original position at one end of a stadium - a plateau supported by an old Hellenic wall one hundred and twelve paces long by fourteen wide, some of the rows of seats in which are still visible. It is impossible to fix a date or assign a cause for the construction of the Keote lion ; one thing is certain, that it is of very archaic work, more so than the lions at the gate of Mycene; and there was an old legend which stated that Kcos was once inhabited by nymphs, who fled from thence to Karystos, fearing a great lion which lived there. It is quite probable that the existence of this granite lion gave rise to this myth, and that it is distinctly belonging to a prehistoric and mythical ageperhaps adorning one end of a Pelasgic stadium. As it reposes now under the shadow of two olive trees, looking down over one of the most magnificent views of Greece, the lion of Keos is an impressive object.

Our home at Keos, though humble, was plcasant. Barba Manthos was our constant companion, and in course of conversation he let us into more secrets connected with the inner life of the Keotes than ever we should have got from eparch or demarch.

Curiously enough, in spite of the size of the town and the communication with Athens, Keos has retained more ancient customs than most of the islands, and it is to be accounted for in this way. The island is large, and there is only one recognised town in it where there is a school. 
Consequently the distant parts of the island are dotted over with tiny cottages called stables ( $\sigma \tau a v$ io $o$ ) - where many families live entirely-consequently the children remain uneclucated, and the parents teach them their superstitions. Some of these 'stables' are congregated together and form hamlets nearly large enough to be provided with a Government school, when matters will be changed; but, as it is, the inhabitants of these outlying hamlets learn nothing, and, perhaps, only visit the town once or twice a year--gencrally if they can on September I I the day of the raising of the cross-and then they bring with them a bundle tied up in a white handkerchief. This they hang on the tripod, on which the tray for holding the cross is put, and they do not take it off again until the cross is raised. This handkerchief contains corn, barley, beans, two roses, figs, garlic, cotton, cocoons, flax, and a little bees' wax. When the time for sowing seed has come they yoke their oxen, and rub a bit of the garlic on their foreheads, and, as they do so, say, "May you, my oxen, and may you, my family, be strong! May the fruits of the earth be blessed!' After this they throw all that the handkerchief contained into the earth, being careful to observe a strict fast on this day.

On September I the owner of one of these 'stables' (rightly, indeed, so called, for they are more fitted for beast than man) has a duty to perform: as soon as he wakes in the morning he must go out of his house and fetch a stone. This he throws into the house, saying, at the same time, 'May my family be healthful, and may money, like this stone, be thrown into my house.'

A Keote farmer has a curious way of preserving his grain-on our expeditions we frequently saw empty round holes in the ground. 'These are called lokkoi,' said Barba Manthos, 'in which our farmers, who have 
no granaries, store their grain. The holes are dug near a threshing floor, and when the grain is ready they put it in, having first been careful to cover the inside with straw. When sufficient grain has been piled up to form a sort of cone-shaped mound they cover the whole with straw, and put on the top of this some of the stiff native brushwood, and then they cover their mound with earth. Rain never penetrates these storehouses, and if it does it is sucked up by the brushwood and the straw before reaching the grain. This is, of course, a very ancient method of storing grain. It is used in none of the Cyclades except Keos now, where, by the side of every threshing floor, we saw two or three lakkoi, which the ancient husbandmen of Greece called oipoi.

Another curious custom still in vogue amongst the husbandmen of Keos carries us back to remote antiquity. St. Anarguris, whose little white church is at

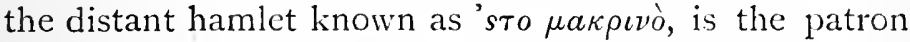
saint of flocks and herds in Keos-the Pan, in fact, of modern days. In Thermià, just over the cavern of Silakka, is built a church in honour of the same saint, recalling forcibly the god of grottoes of ancient days. But this example of Pan worship at Keos is still more marked: whenever an ox is ailing they take it to this church and pray for its recovery. If the cock crows when they start, or they hear the voice of a man, or the grunt of a pig there is every hope that the animal will be cured; but, on the contrary, if they hear a cat, a dog, or a woman it is looked upon as an evil omen. When at the Church of St. Anarguris they solemnly register a vow that if the ox recovers they will present it to the saint when its days of work are over; accordingly every year on July I, the day on which they celebrate the feast of this saint, numbers of aged oxen may be seen on the road to this 
church, where they are slaughtered on the threshold, and the flesh distributed amongst the poor.

Barba Manthos was with us betimes on the following morning, for we were to make a long expedition that day to the ruins of the old town of Karthaia, at the southern end of the island, quite three hours' mule ride from our house. The sun had not risen yet, and a thin mist hung over everything when we started; an atmospheric condition which the Keotes express, as Homer did, by the words $\kappa v \theta \nu a \dot{\varepsilon} \varepsilon, \kappa v \theta 0 s$ - a mist,' said our guide, 'which comes in early spring and is very beneficial to the development of our oak trees.'

When this cleared away we had a glorious day, and we simply revelled in the lovely scenery of Keos after bare, ugly Thermià. The road winds along very high ground; on either side are deep, dark valleys leading down towards the sea, with fantastic rocks and full of oak trees; in the dim morning these great oaks, with their huge stems and stretching arms, looked weird enough. No wonder the superstitious Keotes people them and their cliffs with Nereids; somehow in Keos these mystic beings seem to be brought into closer union with humanity than elsewhere. 'They often,' says the housewife, 'steal her clothes, her sheets, and bed linen, but they nearly alway's return them.' Very often the Nereids have children by human men, for the most part malicious, evil-disposed children. 'Charon must have been your sponsor and a Nereid your dam,' is a frequent expression of abuse to naughty children. For those who are supposed to have been struck by the Nereids when sleeping under a tree the following cure is much in vogue. A white cloth is spread on the spot, and on it is put a plate with bread, honey, and other sweets, a bottlc of good wine, a knife, a fork, an empty glass, an 
unburnt candle, and a censer. These things must be brought by an old woman, who utters mystic words and then goes away, that the Ncreids may eat, undisturbed, and that in their good humour they may allow the sufferer to regain his health.

More interesting even than this relic of the offerings the Athenians once made to the Eumenides on the slopes of Areopagus is another custom the Keotes have of treating children who are supposed to have been struck by these Nereids. In Keos St. Artemidos is the patron of these weaklings, and the church dedicated to him is some little way from the town on the hillslopes; thither a mother will take a child afflicted by any mysterious wasting, 'struck by the Nereids,' as they say. She then strips off its clothes and puts on new ones, blessed by the priest, leaving the old ones as a perquisite to the Church; and then if perchance the child grows strong she will thank St. Artemidos for the blessing he has rouchsafed, unconscious that by so doing she is perpetuating the archaic worship of Artemis, to whom in

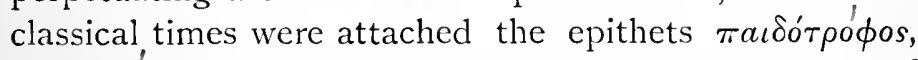

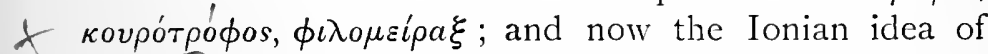
the fructifying and nourishing properties of the Ephesian Artemis has been transferred to her Christian namesake. We found traces of the worship of Artemis having existed in Keos along with that of Apollo in ancient times, for Barba Manthos had a little image of the Ephesian Artemis in his collection, which he had found in a temple at Karthaia.

There is yet another remedy for a sickly boy, peculiar as far as I know, to Keos, but probably a branch of the same system to which I have alluded at Melos and elsewhere. The parents carry the child out into the country and the father selects a young oak; this they split up 
from the root, then the father is assisted by another man in holding the tree open whilst the mother passes the child three times through, and then they bind up the tree well, cover it all over with manure, and carefully water it for forty days. In the same fashion they bind up the child for a like period, and after the lapse of this time they expect that it will be quite well.

We reached Karthaia before midday. 'The city;' as it is vaguely called by the Keotes, in point of choice of site is without a rival ; the spot is sheltered from every breeze except the south by a lofty semicircle of mountains, and all around the vegetation is most luxuriant-magnificent oak trees and yellow spurge in flower, almost shrubs in the luxuriance of their growth. As you descend the hill you traverse the old road, which led from Ioulis to Karthaia, which was protected at frequent intervals by towers.

We spent several hours at Karthaia ; the results of my observations I append in the note. Few Hellenic cities can be morc clearly mapped out than Karthaia, and the excavation which Bronsted carried out with so much good result at the beginning of this century could be conducted easily and with every hope of success if an opportunity were to be given by the Government, for the whole site of the town remains uncultivated, and is only used as a pasturage for flocks by a shepherd, who has a little 'stable' down in the valley, and who refreshed us with some excellent wine. This shepherd rents the whole of the land on which the city stood, and more besides, for the annual sum of two pounds. Sic transit glora mundi!

It was a gloriously warm day; not a breath of wind disturbed us as we lunched on the shore. It was the middle of March according to our style, and the oak 
trees here were in full leaf. Certainly the Greeks of old were exceedingly happy in the choice of the sites for their towns. The wine of Keos is still of great repute, even the shepherd in his 'stable' had an excellent draught to give us out of his gourd. In the middle ages Keote wine was much sought after at Constantinople, and the following advice given by that quaint describer of Byzantine customs, Michael Psello, shows the value in which it was held. 'Chiote wine is beneficial to the eyes ; Pramneion to the cheek-bones, and the bouquet thereof to the channels of the eyebrows; Keote wine, on the other hand, my father, is beneficial to the lips and mouth, sweet to the scent, and black in colour.'

On our return journey we passed by the hamlet of Hellenikà, which is certainly growing in size, and ought soon to be recognised as a centre for education and modern life. Here are extensive ruins of an ancient Greek village; walls and the foundations of houses are still to be seen, for besides the four chief towns on Keos there are traces all over the island of village life and the foundations of numerous watchtowers-everything, in short, proves the once populous state of the island, which must in ancient days have had far more inhabitants than any other island in the Egean Sea, except Paros, in comparison to its size.

On the following day we were to go to Poiessa, the fourth of the towns of Keos, and to take on our way the convent of Hagia Marina, which contains one of the most perfect Hellenic watchtowers in existence. It has taken a rich yellow colour with age, and, on account of its being useful to the monks, it has been preserved from destruction, and is still in a very fair state of preservation. When the convent was at its best they used the tower for cells, and in times of trouble and piratage it 
stood them in good stead as a means of defence; but now it is rapidly falling into disrepair. When king Otho and his queen visited it, accompanied by Ross, the staircase inside was almost intact, so that the royal pair could ascend it and write their names at the top; now you can only get half-way up, and the old man who lives in charge of the ruins and church told us how the king had had a stone taken down, with carving on it, which had loosened the walls, and that soon after part of the tower had given way; so the accusation of robbery and destruction should not entirely be laid on English shoulders. Even now they are contemplating pulling down one of the projecting stones of a balcony, as the old man's granddaughters fear it may fall on their stove and do some considerable damage.

The tower is square, being eleven yards and a half on either side, it is four-storeyed, and has evidently been crowned with battlements, and surrounded on its four sides by projecting blocks of stones, which carried an open gallery, the $\pi \varepsilon p i \delta \rho o \mu o s$ of ancient fortification. As in the tower of Andros, ${ }^{1}$ the stones at the base are huge, but as the tower grows higher they become smaller. There has been a well of water inside the tower, and an underground passage leading from this well to another outside, perhaps used for the double purpose of a channel for water and a secret egress in case of need; all along this passage are niches for putting jars in, but unfortunately it is now too full of stones to go the whole length. Along the road to Poiessa we passed by the ruins of two other towers, but none so perfect as this ; and this one of Hagia Marina is as nothing compared to those of Andros and Amorgos in the preservation of its detail.

The people at the convent, the old man and his 1 Vide p. 3or. 
granddaughters, who till the ground around and look after the church, were most hospitably inclined, and provided us with an excellent mysetlura, hot and fresh. for our midday meal, and we had the further charm of watching it made. They poured fresh goats' milk into boiling whey and then squeezed it and compressed it into a wicker basket until it was compact and beautifully white, and then the honey of Hagia Marina was most excellent, so much so that it caused almost a quarrel between our servant, a native of Anaphi, and the Keotes, which made us, with our peculiar notions of rudeness, feel most awkward. There is simply nothing that is not made the subject for interinsular jealousywine, cheese, honey, hospitality, ruins, and ghost stories; all these things afforded subjects for animated discussion wherever we went.

As the wine flowed freely the old man became exceedingly talkative, and Barba Manthos for our benefit drew him out to tell us the adventures of his long life, some of which were calculated to make the females present awkward if it ever entered into their minds to feel shy.

'And then I became a monk,' said the old man at the conclusion of his narratives, 'that is to say, I light the lamps of the church, sweep it out when it is dirty, and live in a cell.'

'Are not you afraid of living here all alone in this remote corner of the world ?' I asked.

'Nothing would harm an old man like mc,' was his reply; but Barba Manthos privately told me that nobody in the whole island had seen such wonderful hobgoblins as he, for he it was that had made them open old Manetas' grave two years after his death by saying that he had met him in the road, and, sure enough, they found no 
body in the tomb, so they got the priest in hot haste, who poured oil into it and set fire to the oil. At this ceremony the old man declared he saw a blue flame go straight up to heaven, and that he had never seen old Manetas since.

'I heard strange music in my stable the other day,' said the old man musingly, 'and, sure enough, next day' my little granddaughter fell ill; I knew it was the Nereids who did it. Not long after, whilst digging in my field, I found a stick like a cross; this I put upon her bed at night, and, sure enough, next day she was well.' He then told us his firm belief in the evil eye ( $\beta a \sigma \kappa a \nu \varepsilon \hat{\imath} a)$ affecting cattle and trees; for had not three of his healthiest goats sickened and died last year just because a man with the evil eye had admired them? 'The best thing possible for the evil eye,' he said in conclusion, ' is to throw salt into the fire, and let an old woman say some magic worcls, whilst all gape orer the fire with open mouths; and then the priest can do a good deal by reading the proper liturgy for the evil eye, only they have in their ignorance and folly abandoned this good practice of late years.'

Our old friend tottered about with us on his stick, jabbering the while; only too glad to get some one to listen to his stories. He is a type of the Greek of the old rigime, a character that will not be found in another generation in all the realm of Hellas.

The valley which leads down to the little plain of Poiessa is exceedingly lovely: it is all dotted with the hovels of the landowners, and most of them have large white crosses in whitewash over the doorways to save them, they say, from robbers, who haunt these remote places during the sponge-fishing season; but in spite of the crosses not unfrequently their gardens and 
their stores are rifled. Each cottage was redolent with large bunches of pink stocks and other flowers for the benefit of the Keote bees; and as we passed by the kindly inhabitants ran forward with bouquets of them to give us. The fantastic rocks and deep ravines of this valley, called $\mathrm{K} p a \delta \rho a$, made us imagine we were in the Alps.

After our two long rides over Keos a day of rest in the town was enjoyable, but Barba Manthos had no intention of allowing us to be idle; he insisted on taking us up to his little house right at the top of the town, to show us the collection of curiosities he had amassed during his archæological wanderings. A wonderful medley it was-curious old plummet lines for fishing, instruments for polishing and grinding, those little bowls, one inside another, which they used to put in tombs with cotton in them, old weights and measures, a terra cotta Artemis, many lovely specimens of the so-called Tanagra figures, lots of lamps, and lovely scraps of pottery-quite an Hellenic museum, chiefly collected from the suins of Karthaia, which speak for the former opulence of the town. And when we had seen all this he took us for an exhaustive walk over the ruins of Ioulis.

Next day we left our quarters with regret, for the peasantry of the island afford a more than usually instructive study of the past ; they are thrifty and homely: the women make every scrap of household linen themselves, and before a girl marries she likes to have made on her loom all the necessary sheets and towels for her household. From the hair of the goats they make excellent cloaks for the men, which keep off the rain better than any waterproof, and from the cotton grown in their fields the women manufacture articles of clothing, rugs, \&c.; and some Cretan refugees who came to Keos 
in I 866 taught them how to dye their handiwork and make lovely rugs in stripes of red, yellow, and green.

As we rode along in the direction of the ancient miltos mines Barba Manthos told us how in his day the sea had made many encroachments on the northern coast, and how the land was constantly slipping in this part. Curiously enough Pliny tells us that a great piece of the island once fell into the sea, swallowing up men, villages, and all, and Barba Manthos pointed out as we went along a spot where thirty years ago a field with some oak trees had slipped down to a much lower level. It is the same story over again; motions of the crust, upheavals, and subsidences are common in every island, and in former days they must have been more frequent and more tremendous than now, for the evidences of earthquakes, which now are seldom felt in the Cyclades, are numerous, whilst at Chios, and in the Sporades generally, earthquakes are of annual occurrence ; and mythology, with wonderful tales of the appearance of islands and the disappearance of towns according to the caprice of the gods, corroborates the evidence of nature.

The miltos mines are deep holes chiselled in the side of a mountain, about an hour's ride from the town, to the north of the island, and are known as the 'careholes ' by the inhabitants. The chiselled rock has a very bright, rich colour and is strongly impregnated with iron; the marks of the ancient tools are still plain, and numerous lamps have been found inside. It appears that the Athenians produced their much-prized dye by subjecting the stones to heat. About half an hour's ride below the mines is the harbour of Otzia, where there are traces of an ancient mole and of ancient buildings. Doubtless the miltos was shipped from here, and probably many a boat in ancient days here painted its bows and became, as 
Homer expresses it, 'a red-cheeked ship ( $\mu \iota \lambda \tau$ romáp pos vav̂s)'.

Our last ride in Keos was a deliciously warm and pleasant one down the bed of a torrent full of tall, waving oleanders and carpeted with many-coloured anemones. We passed by the harbour of Otzia and soon reached the primitive harbour, where we met the steamer and bid farewell to Barba Manthos, whose intelligent guidance for five days had contributed so much to the pleasure of our stay in Keos.

\section{NOTE. \\ On the Four Ancient Cities of Keos.}

I. Of the four cities of Keos the remains of Koressia, on the spur over the port, offer the least attractions, for Koressia seems to have been abandoned and incorporated with Ioulis even before Strabo's time. There can still be seen the old wall, which stretches along to the end of the promontory, on which once stood what was once a temple of Æolus, as we learn from an inscription, but which is now a church dedicated to St. Saviour. In this wall are the remains of ancient bastions, and higher up was the foundation of another temple, which Barba Manthos was quite sure was that of Smintheus Apollo, for we read of the existence of such a temple at Koressia; but there is no definite proof of its identity. On the foundation of this temple has been raised a church, of the Venetian epoch, dedicated to the Holy Trinity. Inside the city walls were three square towers, the use of which seems doubtful. All the ground is littered with choice bits of pottery, evidencing a considerable advance in the arts.

2. Ioulis, on the ruins of which the modern town is built, contains considerable remains of antiquity. Round the spur of the hill which rises up at the south end of the town, are massive

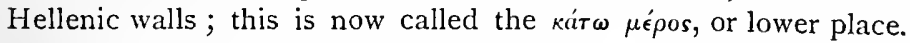
The agora of this town must have been a lovely spot; it is supported by a wall built right over the valley, with an extensive view over sea and mountain. There are some drums of pillars still left here and holes in the natural rock where the decreed tablets in honour of distinguished men $(\psi \eta \phi i \sigma \mu a \tau a)$ of Keos were 
inserted; this agora forms a striking contrast to the dingy space in the middle of the modern town which rejoices in the same highsounding name. Close to this is a spot where once stood an altar to Apollo; the basin for the blood of the victims now forms part of the wall of a cattle stall, together with the bases on which stood statues. A great number of reservoirs and cisterns point to the size and importance of the place. The demarch has built himself a house on the site of an old temple of Athene, as can be gathered from an inscription turned upside down on his doorstep. When digging for the foundations of this house they found many vases, such as the ancient worshippers used to offer flowers in to their goddess ; but, thinking them useless, the workmen broke them all, and the demarch and his family now live on the top of these and, no doubt, many other treasures. As you enter the town on the western side is a well at which tablets in honour of Livia, the wife of the Emperor Octavian, and another in honour of Sabina, the wife of the Emperor Hadrian, are erected. In Roman days Keos seems to have been of considerable importance; it was not used as a place of banishment-it was too pleasant for that-but probably as a meeting place for ships and traffic eastwards. Virgil thus speaks of it :-

Et cultos nemorum cui pinguia Kex

Ter centum nivei tondent dementa Juvenci.

To the east are the stadia. I have already alluded to the one on which the lion stood, a plateau held up by a wall, facing south and sheltered; this must have been the winter stadium. Just across the valley is a similar plateau facing north; it is very probable that this would be used as a summer stadium.

3. Karthaia must have been quite the pleasantest city of Keos; and it is curious, too, from its geographical position : a long spur runs down a valley surrounded on the north, east, and west by lofty mountains to the sea, dividing it into two almost equal portions; the one on the east was devoted to the cemetery, both Greek and Roman, many of the graves of which had been destroyed by the encroaching sea. In the western part were some of the chief public buildings. The town and the acropolis are on the spur.

Karthaia was the scene of a diligent excavation in $18 \mathrm{r}$, carried on by the Danish archrologist Bronsted. He stayed here seven weeks, and by the discovery of inscriptions identified the place as 
Karthaia, for hitherto Ioulis had been supposed to be Karthaia, and vice versia. At the end of the spur leading into the sea Bronsted identified by an inscription the celebrated temple of Apollo of Karthaia, and in a niche of the rock overlooking the sea was found a portion of the statue of that god, which he removed. Just above this temple must have been the platform where Simonides gave his music lessons, whence the ass, Epeios by name, brought up water from the well and suggested to the tutor the punishment that each pupil who was late should give a measure of oats to Epeios (Athenæus, 'Deiphosoph.'), thereby explaining that epigram of his, "Think well, that whoever of you does not wish to dispute the prize of the grasshopper must give a great dinner to the Panopeiade Epeios.'

Besides this temple Bronsted made many other valuable discoveries-fragments of a statue resembling the Apollo Musagetes in the Vatican, marble decrees concerning the relations between the Keotes and Æolians, and bits of excellent work. The ancient Greeks of Karthaia were advanced in the arts, as is evinced by a beautiful tombstone we were shown in the demarcheion of Keos of a woman and child which had lately been discovered at Karthaia. But these things only prove what a vast deal more there is buried in the soil here. A few years ago in the western valley an inscription was discovered proving the existence of a temple of Æsculapius. The demarch of Keos immediately organised an excavation, and discovered the wall of a temple; but the Government got to hear of it, and forbade any further digging; and the consequence is that the spot is now almost entirely hidden by the soil that has been washed over it by the rain. Close to this spot is the theatre of Karthaia, very much damaged, but the form of it still distinct; and all along the spur of the hillside are huge Cyclopean stones, those which supported the proaulion of the temple of Apollo, having been further supported by the later introduction between them of Roman masonry. One of the stones in the wall on the western slope I measured, and found it to be four yards thirteen inches in length and over two yards in width. On the summit of the spur was the acropolis and the ruins of a temple of Artemis, now converted into a little church dedicated to the Virgin. The ancient entrances into the walls are still easily recognisable, and the two approaches which came up the spur on either side and entered the wall of the inner city by one gate just behind the temple of Apollo.

Karthaia possesses a circular but badly protected bay, where 
no boats can approach in a southern wind, though the old mole, which once joined the island rock in the bay to the mainland, must have afforded some protection to small craft. On a cliff projecting

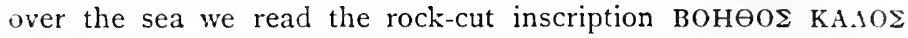
IIMHNAIO. Above the town are traces of the old mountain roads which joined Karthaia to Poiessa, which latter town shared the fate of Koressia, and was incorporated in the bigger Karthaia. These four cities in one small island do not seem to have been of one mind by any means; we read of treaties between Athens and Ioulis in which Karthaia was not included, though only a few miles apart; but then the mountain barrier between them is far greater than that which existed between Athens and her rival on the Thriasian plain.

4. Poiessa, the fourth Keote city, was built on a hill projecting into the sea or the western side of the island, from the summit of which a lovely view up the Saronic Gulf to distant Attica is obtained. There were two little temples on the summit, one of which was dedicated to Apollo, and gazes directly on its more celebrated namesake, the white temple of Sunium. One point of interest which we noticed here was an ancient cistern for rain water, so constructed that the water could clear and mud settle before it ran into the main tank by means of a gallery. Otherwise the ruins of Poiessa are uninteresting-a place of secondary importance, a sort of fishing village-and amongst the ruins of it have been found more plummets for sinking lines than in either of the other towns. 


\section{CHAPTER XIX.}

\section{AMORGOS.}

\section{During Easter Week.}

THIS, the remotest island of the Cycladic group, and the bulwark, so to speak, of the modern Greek kingdom, would well repay a visit at any other time than Easter week for its quaint costumes and customs and unadulterated simplicity. But those are luckiest who can visit it then, for Easter is the great festival ( $\pi a \nu \eta^{\prime} \gamma v \rho \iota s$ ) of Amorgos, and is unlike Easter in other parts of Greecc at this time, for the Amorgiotes devote themselves to religious services and observances which now scandalise the more advanced lights of the Hellenic Church, and greatly annoy the liberal-minded Methodios, Archbishop of Syra, in whose diocese Amorgos is situated, and who cannot bear the prophetic source $(\mu a \nu \tau \varepsilon \hat{\imath} 0 \nu)$ for which this island is celebrated, and would stop it if he dared; but popular feeling, and the priests, who gain thereby, prevent him.

The steamer now touches here once a week-a dangerous enemy, indeed, to these primeval customs, but pleasanter than a caĩque-so we availed ourselves of it, and armed ourselves with a letter of introduction to the demarch, for we had heard sorry rumours about the honesty of the men of Amorgos and their proneness to 
theft, the fact being that Amorgos was one of the last strongholds of piracy, and consequently the evil name has stuck to them in spite of the abandonment of their nefarious practices.

It is seldom calm between Amorgos and her neighbours; the full force of the Icarian Sea runs into a narrow channel which separates her from some smaller islands, and the limpet rocks and the black nose of Amorgos are justly dreaded by mariners. This fact, again, prior to the advent of the steamer, tended to keep the Amorgiotes to themselves.

When reached the harbour of Amorgos is large and secure enough from all but a western gale, and we landed at a few houses down by the quay, which in themselves do not afford any interest; but they are built on the site of the old port of Minoa, one of the three cities of Amorgos, and contain plenty of ancient remains.

On leaving this place, Katapolis, or lower town, as it is called, we walked up a fertile olive-clad valley, and, after an hour's climb, we reached the town, situated 1,000 feet above the sea, in a strong position, where pirates could not molest it, and where everyone stared at us as if we had come from the antipodes. The chief feature of the place is a big rock, Ioo feet high, rising straight out of the centre of the town, on which the mediæval fortress stood, and around which cluster the flatroofed houses. From the top the view over the muchindented coast and peaky mountains of Amorgos is truly magnificent, for Amorgos is riband-shaped-very narrow and long-with lofty mountains and deep bays; so we tarried for a long time on this spot, admiring the scene around us. Until quite recently the town consisted only of a belt of houses tightly packed around this rock, with 
one church of considerable age. In this we saw some interesting votive offerings. Round an eikon of the Madonna was a wedding wreath which, we were told, a spinster had vowed to the Panagia in case she got a husband. This stroke of good fortune eventually befell her, and consequently she fulfilled her vow. Mothers whose children have recovered from illnesses have presented wax figures of them to the Madonna; and all along the screen were hung feet, arms, ships, each of which had a history to tell of relief from pain or peril. It is but an old idea which the Greeks have inherited from their ancestors; similar things have been unearthed from the ruins of ancient temples-votive offerings to the gods.

The first object which struck us was the costume of the elderly women. That wretched steamer has brought in Western fashions now, so that the younger women scorn their ancestral dress; but the old crones still seem to totter and stagger beneath the weight of their traditional headgear. There is a soft cushion on the top of the head, a foot high at least, covered with a dark handkerchief and bound over the forehead with a yellow one; behind the head is another cushion, over which the dark handkerchief hangs half-way down the back, and the yellow handkerchief is brought tightly over the mouth, so as to leave only the nose projecting, and is then bound round so as to support the hindermost cushion. This complicated erection rejoices in the name of tourlos or 'the tower,' and is hideously grotesque, except when the old women go to the wells, and come back with huge amphore full of water poised on the top of it, plying their spindles busily the while, totally unconcerned about the weight on their heads. Naturally a headriess such as this is not easy to change, and the old women rarely move 
it until their heads itch too violently from the vermin that have collected within.

With the exception of the troulos, or tourlos, the silks and brocades of olden days are a'bandoned in ordinary life. Only on the feast day did we see the rest of the old Amorgiote costume.

We made our way, first of all, to the public kaffeneion, where the magnates were assembled, and where I was the observed of all observers. A half-witted old man, Spiro by name, took a great fancy to glaring at me, and talking at $m e$, and otherwise bringing me into unenvied observation. Poor Spiro had seen better days, but now lived from hand to mouth - a meal here and a crust there. He always carried a bag with him full of cigar and cigarette ends, with the tobacco of which he made his own cigarettes folded in scraps of old newspaper; and then when pleased he would sing stirring national songs with ridiculous pathos, which made all his hearers roar with laughter.

From out of the café window we had a view down a street full of wells, over twenty of them. Every householder has a right to sink one here if he is rich enough; if not he has to put up with the public wells, which are a few paces above, and walled in. It was a pretty sight to watch the old women going to fetch water, with their amphore tottering on their heads and their white knitted gloves on their hands, a speciality of Amorgos.

The demarch received us rather gruffly at first; he was busy with the weekly post which had arrived by our steamer. He distributes the letters, there being no postman in the island. But when his labours were over he regaled us with the usual Greek hospitality-with coffee, sweetmeats, and raki, and then prepared to lay out a programme for our enjoyment. 
At a glance we could see that he was a tyrant in his own house, and his wife a poor, oppressed creature, not unlike one of those women whom Simonides of Amorgos describes in his fragment on women-a chattel not to appear in society, but to do all the cooking and slavery of the house.

As soon as he had sent off the last letter he became jollity itself; as they express it in these parts, ' $\mathrm{He}$ is pinks to his neighbours, thistles to his household.'

'Papa Demetrios,' said he, 'is the only man who knows anything about Amorgos.'

So the said priest was forthwith summoned, and entrusted with the charge of showing me the lions of Amorgos.

'We had better visit the points of archrological interest first,' said the priest. 'Next week we shall be too busy with the festival to devote much time to them.'

So accordingly the three next days were occupied in visits to remote parts of the island, old sites of towns, old towers, and inscriptions, whilst the world was preparing for the Easter feast.

On Good Friday evening-- the vigil of St. Lazarus, as it is called in the Greek Church-we met a group of children going from house to house, clad in light muslin garments, and carrying in their arms an elaborately dressed doll. 'This is Lazarus,' they said in answer to my enquiries as to who the doll was intended to represent, and they went on singing from door to door. It is in a measure a sort of passion play. Thanks to Papa Demetrios, I was able to get their words. A child sings to the one who carries the doll-

'What did you see in Hades, my Lazarus?'

to which the other with the doll replies- 
'Dread sights I saw, and terrors dire;

Punishments I saw, infernal fire.

Kind neighbours, just a drop of water spare,

From off iny lips and heart to cleanse

The poisonous vapours of the lower air,

And seek no more to learn.'

And then the kind neighbours produced various articles of food-eggs, cakes, \&c.--which Miss Lazarus put into her basket, and continued her story at another door.

I do not propose to narrate the usual routine of a Greek Easter-the breaking of the long fast, the elaborately decorated lambs to be slaughtered for the meal, the nocturnal services, and the friendly greetings; of these everybody knows enough-but I shall confine myself to what is peculiar to Amorgos, and open my narrative on a lovely Easter morning, when all the world were in their festival attire, ready to participate in the first day's programme.

First of all I must take the reader to visit a convent dedicated to the life-saving virgin ( $\pi$ avayia $\left.\chi \omega \zeta \omega \beta \iota{ }^{\prime} \tau \iota \sigma \sigma a\right)$, the wonder of Amorgos. It is the wealthiest convent in Greece next to Megaspelaion, having all the richest lands in Amorgos, and the neighbouring islands of Skinousa and Karos belong exclusively to it, besides possessions in Crete, in the Turkish islands, and elsewhere. The position chosen for this convent is most extraordinary. A long line of cliff, about two miles from the town, runs sheer down I,O0O feet into the sea; a narrow road, or ledge, along the coast leads along this cliff to the convent, which is built half-way up. Nothing but the outer wall is visible as you approach. The church and cells are made inside the rock. The whole, as Tournetort aptly expresses it, resembles a chest of drawers. This convent was founded by the Byzantine emperor Alexius Comnenus, whose picture existed until lately, 
but they suffer here frequently from rocks which fall from above, one of which fell not long ago and broke into the apse of the church and destroyed the picture of the emperor.

We entered by a drawbridge, with fortifications against pirates, and were shown into the reception room, where the superior, a brother of the member for Santorin, met us, and conducted us to the cells in the rock above, to the large storehouses below, and to the narrow church, with its five magnificent silver pictures, three of which were to be the object of such extraordinary veneration during Easter week.

The position of this convent is truly awful. From the balconies one looks deep down into the sea, and overhead towers the red rock, blackened for some distance by the smoke of the convent fires; here and there are dotted holes in the rock where hermits used to dwell in almost inaccessible eyries. It is, geographically speaking, the natural frontier of Greece. Not twenty miles off we could see from the balcony the Turkish islands, and beyond them the coast of Asia Minor. In fact the Turkish island of Astypalæa seems scarcely five miles away. The Greeks say it ought to belong to them, but when the boundary line was drawn by the representatives of the Powers in conference, they had such a bad map before them that it was assigned to Turkey. Our friendly monks looked too sleepy and wanting in energy to think of suicide, otherwise every advantage would here be within their reach.

Three of the five silver eikons in the church were to be the object of our veneration for seven days to come. One adorns a portrait of the Madonna herself, found, they say, by some sailors in the sea below, in two pieces, in which condition it was washed all the way from 
Cyprus, having been treated profanely there. It is beautifully embossed with silver and gold, as are also the other cikons. This fashion of fulfilling a vow by putting a silver arm or limb on a sacred picture has had a curious effect on the general appearance, and reminds us of the statue mentioned by Lucian which Eucrates had in his house, and had gilded the breast as a thank-offering for recovery from a fever. A second is of St. George Balsamitis, the patron saint of the prophetic source of Amorgos, of which more anon; and another is an iron cross, set in silver, and found, they say, on the heights of Mount Krytelos, a desolate mountain to the north of Amorgos, only visited by peasants, who go there to cut down the prickly evergreen oak which covers it, as fodder for their mules.

We were up and about early on Easter morning; the clanging of bells and the bustle beneath our windows made it impossible to sleep. Papa Demetrios came in, dressed exceedingly smartly in his best canonicals, to give us the Easter greeting. Even the demarch was more condescending to his wife to-day. At nine o'clock we and all the world started forth on our pilgrimage to meet the holy eikons from the convent. The place of meeting was only a quarter of a mile from the town, at the top of the steep cliff, and here all the inhabitants of the island from the villages far and near were assembled to do reverence.

I was puzzled as to what could be the meaning of three round circles, like threshing floors, left empty in the midst of the assemblage. All round were spread gay rugs and carpets and rich brocades; everyone seemed subdued by a sort of reverential awe. Papa Demetrios and two other chosen priests, together with their acolytes, set forth along the narrow road to the 
convent to fetch the eikons, for no monk is allowed to participate in this great ceremony. They must stop in their cells and pray; it would never do for them to be contaminated by the pomps and vanities of so gay a throng. So at the convent door, year after year at Easter time, the superior hands over to the three priests the three most precious eikons, to be worshipped for a week. A standard led the way, the iron cross on a staff followed, the two eikons came next, and as they wended their way by the narrow path along the sea the priests and their acolytes chanted monotonous music of praise. The crowd was now in breathless excitement as they were seen to approach, and as the three treasures were set up in the three threshing-floors everybody prostrated himself on his carpet and worshipped. It was the great panegyris of Amorgos, and of the 5,000 inhabitants of the island not one who was able to come was absent.

It was an impressive sight to look upon. Steep mountains on either side, below at a giddy depth the blue sea, and all around the fanatical islanders were lying prostrate in prayer, wrought to the highest pitch of religious fanaticism.

Amidst the firing of guns and ringing of bells the eikons were then conveyed into the town to the Church of Christ, a convent and church belonging to the monks of Chozobiotissa, and kept in readiness for them when business or dissipation summoned them to leave their cave retreat. Here vespers were sung in the presence of a crowded audience, and the first event of the feast was over.

Elsewhere in Greece on Easter Day dancing would naturally ensue, but out of reverence to their guests no festivities are allowed of a frivolous nature, and every une walks to and fro with a religious awe upon him. 
Monday dawned fair and bright, as days always do about Easter time in Greece. Again the bustle and the clanging of bells awoke us early. There was a liturgy at the Church of Christ, where the eikons were, and after that a priest was despatched in all hurry up to the summit of Mount Elias, which towers some 2,000 feet above the town. Here there is a small chapel dedicated to the prophet, and this was now prepared for the reception of the eikons by the priest and his men, and tables were spread with food and wine to regale such faithful as could climb so far. Meanwhile we watched what was going on below in the town, and saw the processions form, and the eikons go and pay their respects to other shrines prior to commencing their arduous ascent up Mount Elias. It was curious to watch the progress up the rugged slopes, the standard bearer in front, the eikons and priests behind, chanting hard all the time with lungs of iron. Not so my friend the demarch, with whom I walked. His portly frame felt serious inconvenience from such violent exercise, so we sat for a while on a stone, and he related to me how in times of drought these eikons would be borrowed from the convent to make a similar ascent to the summit of Mount Elias to pray for rain, and how the peasants would follow in crowds to kneel and pray before the shrine.

It is strange how closely the prophet Elias of the Christian Greek ritual corresponds to Apollo, the sun god of old; the name Elias and Helios doubtless suggested the idea. When it thunders they say Prophet Elias is driving in his chariot in pursuit of dragons; he can send rain when he likes, like ö $\mu \beta p$ of ancient mythology; and his temples, like those of Phœbus Apollo, are invariably set on high, and visited with great reverence in times of drought or deluge. 
After the liturgy on Mount Elias the somewhat tired priests partook of the refreshments prepared for them, for Phœbus Apollo was very hot to-day, and the eikons were heavy; and my host, the demarch, enjoyed himself vastly, for his pious effort was over, and the descent was simple to him.

All the unenergetic world was waiting below, but we who had been to the top felt immensely superior, and Papa Demetrios gaily chaffed the lazy ones on the way to vespers in the Metropolitan Church for their lack of religious zeal. Here the eikons spent the second night of their absence from home. I was very curious about the next day's proceedings, for on Tuesday the eikons were to visit the once celebrated Church of St. George Balsamitis, where is the prophetic source of Amorgos. So I left the town early with a view to studying this spot, and if possible to open the oracle for myself before the crowd and the eikons should arrive. It is a wild walk along a narrow mountain ridge to the Church of St. George, about two miles from the town. Here I found Papa Anatolios, who has charge of this prophetic stream, very busily engaged in preparing for his guests. A repast for twenty was being laid out in the refectory, and he said a great deal about being too much occupied when I told him I wished to consult his oracle.

At the beginning of this century and during the war of independence this oracle of Amorgos was consulted by thousands: sailors from all the islands round would come to consult it prior to taking a lengthened voyage; young men and maidens would consult it prior to taking the important step of matrimony : but during the piratical days which followed, the discovery was made that evilintentioned men would work the oracle for their own ends. The spot is unprotected and easy of approach 
from the sea, so the pirates used to bribe the officiating priest to send an unwitting mariner to his doom. Despite all this the oracle is much consulted by the credulous, and reminds one forcibly of the shrine of Deiphi of old, or the sanctuary of Trophonius, in the fluctuations of popular favour which have attended its utterings.

There is the church on the slopes of a hill commanding an almost deserted valley, there are the tall religious cypresses towering above it. The genius of the place is decidedly awe-inspiring. No habitations are near, only the ruins of an old water mill, garlanded with maidenhair, which was once doubtless worked by a branch of the sacred stream. Over the doorway as I entered I read that the church was repaired in 1688 , and then $I$ stepped with Papa Anatolios into the dark pronaos, covered with frescoes representing the adventures of St. George, the modern Theseus, of St. Charalambos, the modern Asculapius, and of St. Nicholas, the modern Poseidon, the tutelary deity of seamen.

On entering the narthex Papa Anatolios still demurred much about opening the oracle for me, fearing that I intended to scoff; but at length I prevailed upon him, and he put on his purple stole, ${ }^{1}$ and went hurriedly through the liturgy to St. George before the altar. After this he took a tumbler, which he asked me carefully to inspect, and on my expressing my satisfaction as to its cleanness he proceeded to unlock a little chapel on the right side of the narthex with mysterious gratings all round, and adorned inside and out with frescoes of the Byzantine School.

1 'Emı $\rho \alpha \chi \eta^{\prime} \lambda เ o v$, through which the priest puts his head, and the ends hang down in front; sometimes they are studded with gold and gems. They are worn at every sacred function. 
Here was the sacred stream, the i $i \gamma \grave{a} \sigma \mu a$, which flows into a marble basin, carefully kept clean with a sponge at hand for the purpose lest any extraneous matter should by chance get in. Thereupon he filled the tumbler and went to examine its contents in the sun's rays with a microscope that he might read my destiny. He then returned to the steps of the altar and solemnly delivered his oracle. The priests of St. George have numerous unwritten rules, which they hand down from one to the other, and which guide them in delivering their answers. Papa Anatolios told me many of them.

I. If the water is clear, with many white specks in it about the size of a small pearl, and if these sink but rise again, it signifies health and success but much controversy. II was a foreigner and a guest, so politely he prophesied this lot for me.

2. If there is a small white insect in the water, which rushes about hither and thither in the glass, there is no fear of storm or fire.

3. Black specks are bad, and indicate all sorts of misfortunes, according to their position in the water ; if they float they are prospective. Some that appeared in my glass sank; these Papa Anatolios told me referred to difficulties of the past.

4. Hairs are often found therein ; these indicate cares, ill-health, and loss of money. From these I was luckily exempt, but my unfortunate servant, who tried his luck after me, had lots in his glass. Poor man! he never recovered his peace of mind till dinner time, when the enlightened demarch laughed at his fears and told him some reassuring anecdotes.

5. When you ask a direct question concerning matrimony or otherwise the wily priest regulates his answers 
by these microscopic atoms which float in the glass. If the marble bowl is empty at Easter time the year will be a bad one; if full. the contrary. This is easily accounted for by the rainfall.

These and many other points Papa Anatolios told me, and I thanked him for letting me off so mercifully.

To my surprise on offering him a remuneration for opening to me the oracle he flatly refused and seemed indignant.

Whilst waiting for the guests Papa Anatolios discoursed frecly about his oracle. Centuries ago, he said, some lepers had bathed here and became clean, thereupon they dug in the ground and found the eikon of St. George, which now, set in silver, is kept at the convent, and was just about to revisit its hiding-place. The church of the oracle is rich, and at various epochs it has been filled with ex woto offerings, such as wedding wreaths from those who have consulted the oracle prior to matrimony and have been satisfied with the result; silver ships from mariners whose course has been directed safely by the oracle. All manner and kind of gifts were hanging up here and there in dazzling confusion, very like, I thought, what an old heathen temple must have looked when hung around with the avatinata to the gods. Nowhere is one brought so closely face to face with the connecting links between heathendom and Christendom as one is in Greece.

About midday we heard the distant chanting of the procession, and soon the three eikons and their bearers were upon us. After the liturgy was over, and the religious visit paid, we had a very jolly party in the refectory. Papa Anatolios produced the best products of the island-lambs, kids, fresh-curdled cheese, wines, and fruits-and it was not till late in the afternoon that 
we started on our homeward route, still chanting and still worshipping these strange silver pictures from the convent.

With regard to the antiquity of this prophetic source there is little reliable information. Everyone who has been to Amorgos, from Father Richard in 165 i to Ross in $184 \mathrm{I}$-all mention it, but they, curiously enough, cnly mention that the oracle was taken from the rise and fall of the water. Capo d'Istria when he took the head of the government in regenerated Greece ordered this as well as a prophetic source in the island of Scyros to be closed, but the popular feeling was too strong - it had to be restored. These things seem to flourish under opposition, and to die a natural death only when attacked by progressive civilisation.

We were all rather tired that evening on our return from the oracle, so next morning the bells failed to wake us early, and I was glad to learn that the eikons had started on a visit to a distant place where I had already been-Torlaki---where was an old Hellenic watchtower; so during the early part of the day I strolled quietly about the town, and ingratiated myself as best I could into the good graces of the old women of the place, who had much that was quaint to tell me.

I had heard of Kera Maria's wonderful skill in incantations, and accordingly wished to hear some of them. It is exceedingly difficult to get at these quack charms for curing diseases by the magic of certain words, full faith in which exists largely in the renote islands, to the exasperation of the local Hippocrates. The old witch in question was, of course, busy with her loom, so I sent my man before me to inform her-by no means an untruth - that the English gentleman had a pain, and having heard of her skill in magic was 
desirous of being relieved of the same. She mumbled to herself as I entered, and as she mumbled she made. certain curious signs; her words were very indistinct, but that evening, thanks to the kindly aid of Papa Demetrios, I was able to obtain them; and append a literal translation :-

Helly ! woeful belly !

Woeful and fearful that thou art,

Down on the seashore, down on the beach,

Are three spoons,

One of them has honey, another milk, another the entrails of a man. Eat honey, drink milk, and leave the bowels of the man.

The quaintness of these incantations struch me forcibly in my wanderings through the islands. I collected many of them, but none quainter than this. Erysipelas, too, she says she can cure by putting a little honey on a dish, and taking a feather at the same time and rubbing the honey on the wound as she chants some mystic words. Whether I benefited by the old dame's cure or not I shall never know; at all events I was strong enough that evening to walk down to the seashore to see the arrival there of the eikons, with their wonted accompaniment of chanting and festivity. The little harbour village was decked with flags, the caïques and brigs were also adorned, and a good deal of firing was going on in honour of the event. That evening the eikons and I passed by the harbour, certainly to my personal discomfort, for never in the course of my wanderings did I rest under a dirtier roof than that of Papa Manoulas. $\mathrm{He}$ is a prorerbial Greek priest, having a family of eleven children ; he keeps a sort of wineshop restaurant for sailors, and excused the dirtiness of his table by saying that men had been drunk in his house the night before. He cooked our dinner for us in his tall hat, cassock, and shirt sleeves, 
and then put me to sleep in a box at the top of a ladder in one corner of the café, which was redolent of stockfish and alive with vermin.

I wanted no waking next morning, and was pacing the seashore long before the eikons had begun their day's work; it was fresh and bright everywhere except in Papa Manoulas' hole. To-day was to be the blessing of the ships, and as every Amorgiote, directly or indirectly, is interested in shipping, it was the chief day in the estimation of most. When the procession reached the shore the metropolitan priest of the island entered a barque decorated with carpets and fine linen, carrying with him the precious eikon of the life-saving Madonna: he was rowed to each ship in turn, and blessed them, whilst the people all knelt along the shore; and as each blessing was concluded a gun was fired as a herald of joy. The rest of the day was spent in revelry. I was glad not to be going to pass another night under Papa Manoulas' roof, for I felt sure that it would be dirtier than ever.

Friday and Saturday were passed by the eikon.s and priests in complimentary visits and liturgies in the numerous churches in and around the town. I did not accompany them on these journeys, and persuaded Papa Demetrios to come off with me on an excursion, for he, too, was tired of these repeated ceremonials, and was not sorry to transfer his eikon to inferior hands.

The Sunday next after Easter may be said to be the real festival in Amorgos, for on this day the eikons return to their home. The same concourse of people assembled on the spot where they met them to bid farewell, and 500 men then accompany the three priests all the way to the convent along the narrow road; and the monks beneficently present each with as much bread and cheese as he can carry, for which purpose large 
baskets full of these materials were collected at the convent door; and the Easter dole took up well-nigh all the afternoon.

Towards five o'clock there was a going to and fro in the little plateau before the church. Old women with the large wagging tourlos on their heads arrived to get a good position for the sight, each with their little stool under their arms - these stools being about six inches high, and made of cross bits of wood and covered with goats' skin. Places were reserved for the demarch and ourselves on a stone ledge which runs along the façade of the church. The musicians came, and had seats placed for them under the wavy plane tree which occupied the middle of the square. There were three of them: one with a cithara, another with a lyre, and another with a flute. They were gay, lively fellows, and often made impromptu verses to their tune. One of these the demarch, who sat by me, repeated, and said it had been to urge on the guests that were idle in the dance; and on my expressing surprise and, perhaps, a little incredulity, he stepped up to the musicians, evidently to tell them to sing a verse especially for my benefit. Presently, whilst I was making a little sketch of one of the dancers unobserved, as I thought, to my great discomfiture a couplet was hurled at me, which made everyone laugh, and which ran as follows :-

The costume of Amorgos is very much admired, For the Englishman sitting there has made a picture of it.

So I was thoroughly convinced of the musicians' ability for impromptu versification. After half an hour's delay the chief priest came and took the place of honour, being a stone armchair on the same ledge on which we 
were sitting, and this was the signal for the musicians to begin. The week's veneration for the eikons was at an end, and the Amorgiotes were now prepared for enjoyment.

Everyone knows the beauties of the Greek syrtos, as the dance goes waving round and round the plane tree in a village square, now fast, now slow, now three deep, now a single line, and then the capers of the leader as he twists and wriggles in contortions. Here in Amorgos the sight was improved by the brilliancy of one or two old costumes. One lady especially was resplendent : her tourlos was of green and red, her scarf an Eastern handkerchief, such as we now use for antimacassars ; coins and gold ornaments hung in profusion over her breast, her stomacher was of green and gold brocade, a gold sash round her waist, and a white crimped petticoat with flying streamers of pink and blue silk, pretty little brown skin shoes with red and green embroidery on them. She was an excellent dancer, too, a real joy to look upon. The men wore their baggy trousers, brightcoloured stockings, and embroidered coats ; but the men of Amorgos are not equal to the women. The beauty of an Amorgiote female is proverbial. Thus the festivities of Easter week were brought to a close. We will now wander through the island with Papa Demetrios, and see its beauties. 


\section{Through the Island.}

One of our expeditions before Easter began was to the northern end of the island, the demarchy of Aigiale, where Papa Demetrios engaged to show us five villages, the remains of antiquity, and lovely scenery. Papa Demetrios was in many ways a most intelligent man, but, as is usual with the Greek priest, he is a peasant of humble origin; but he is devoted to archaology, and before we started he took me to his house, where he had collected all sorts of odds and ends from all parts of his native island: he, his stalwart wife, and his quiverful all dwelt in two rooms, with hardly any furniture in them except antiquities-fine, large amphore, an interesting stele representing Charon in his boat handing in the dead, which boat apparently had a canvas bulwark just like a modern caîque. Then there were all sorts of ancient tools-basalt instruments for polishing marble, weights and measures, plummet lines, \&c., baskets full of lamps and heads. Again, Papa Demetrios is well versed and interested in the folklore of his country; he does not believe quite all he hears or quite all he preaches, but then for expediency's sake it is better to humour the people.

It was a wet morning, and the good priest would willingly have stopped at home had I not urged him to start. "God is emptying His bowl," my parishioners Ivould say,' and then he explained the prevalent idea that God, like Zeus of antiquity, has a bowl or receptacle full of water, which He shakes, and then clouds come out ; these fall to the earth as rain or snow. Symptoms of 
clearing up having set in by eleven, we started, and took our way along the western coast. Quite a speciality of Amorgos are the well-preserved Hellenic towers; there are more here than I observed in any island, and the one at Arkesini is about the best in Greece. We passed by two on our expedition this morning, the first at a spot called Torlaki, a square one with traces of an arched door. Further on, at Richti, we passed a round one, ten and a half yards in diameter, with an entrance one yard four inches wide, and part of the wall forty feet high still standing, with narrow windows for shooting out of still preserved. We saw several other watchtowers on our way, and about two o'clock we drew up at a mandra for some refreshments; it was all full of smoke and filth, but everyone knew and worshipped Papa Demetrios - he had but to command, and the thing was done.

As we approached the bay of Aigiale to our left we passed the island of Nikousia, which protects this harbour, and is used as a place of banishment for Amorgiote lepers. And then about five hours after leaving the capital we entered the demarchy of Aigiale, which consists of five villages dotted up and down an exceedingly fertile valley. Down by the harbour is the village of St. Nicholas, where there are lots of ruins, chiefly of the Roman epoch, vaulted tombs, and a place which must have been a bath and the remains of a temple. Amorgos was a place of banishment, and the exiles seem to have tried to make their sojourn here as endurable as possible; it must have been life instead of death to Vitrius Serenus, when Tiberius decided to send him here instead of to Gyaros.

As the afternoon was growing late we climbed up to the village of Tholaria, where Papa Demetrios promised us comfortable quarters for the night ; and we arrived just in 
time to see the old women returning from vespers with their tourli wagging on their heads. One of these Papa Demetrios accosted ; she touched the ground and kissed his proffered hand; and he then smilingly asked her if she had been doing anything in the magic line lately.

She at first flatly denied any intercourse with the livil One, with the vehemence of an Irish woman accused of stealing potatoes; but on the prospect of a slight re. muneration from the stranger she at length admitted that she knew a thing or two. She could prepare a good love potion, she said, warranted to bring a suitor to any love-sick damsel.

'Get an animal, a mule, or a goat, even a dog will do if you can get nothing better, open its mouth, and make it bleed some drops into your frying pan. Cook the dinner in this without blowing the fire, and see that the man to be won eats of this dish.'

I could never have wormed this secret out of the old woman if I had not been aided and abetted by Papa Demetrios. I tried myself to get something out of another old woman, but she only laughed at me and sang the following punning distich, "I was born in May (Maia), hence I fear no magic (Maysıa, $\gamma$ scarcely pronounced) will hurt me in my bed.'

Next morning we went to a spot called Vigla now, but which was the site of the ancient town of Aigialc: it must have been a strong place, commanding sea and land, and has been chosen as a fortress by the three successive epochs of Greek, Roman, and Frank, as the ruins attest; it was probably the acropolis of the valley of Aigiale, then, as now, dotted over with villages. Within the old walls we saw the bases of three statues standing, evidently in their old position side by side, one of which, by the inscription we saw, had been dedicated 
to Hera. In the neighbourhood of this fortress are quantities of vaulted tombs, of the Roman cpoch, called tholaria ( $\theta$ ó $\lambda o s$, a dome), and which gives the name to the modern village.

After the first winter rains the urchins of Tholaria drive a famous trade in ancient coins up here, which they find amongst the ruins. Many of these have the curious device of Aigiale, which Mr. Lambros, of Athens, has lately identified as a cupping instrument, from which he argues that Aigiale was dedicated to Esculapius.

Before the heat of the day came on our cavalcade left Tholaria, and we commenced our journey round the valley which encircles the harbour. It is most admirably cultivated in terraces forming narrow fields which run up the mountain sides to a great height.

The first village we halted at was Strymbo, built in an almost inaccessible gorge - a wretched hamlet, but exceedingly picturesque, the inhabitants of which are much despised by their neighbours, as uncongenial, and a trifle nefarious in their practices. A proverb runs in Amorgos expressive of supreme contempt: "It is like Strymbo with eight houses and twelve ovens.' Certainly we counted a great many ovens, but the houses were decidedly more numerous than their supercilious neighbours admit.

Next we came to Langada, the chief village of the demarchy and the seat of government. Here the women were busily engaged in the streets in preparing wool for their looms. For this purpose they had long rope-walks down the streets, made of reeds and vine-tendrils fastened on strings, with stones to steady them ; these spin round at a rapid rate as they work, and are called $\kappa a \lambda a \nu a ́ \delta \rho a$. Close to Langada is a fortified refuge from pirates on a rock above the viilage, most difficult of access even when 
there is nobody shooting at you from above. It is fortified with walls and machicolations, and at the top is a tiny church and holes cut in the rock for the protection of the soldiers. These times are over now; but they still have a feast day here, and climb up to invoke the blessing of the Holy Trinity.

I did not like the wine they gave us at a remote spot where we lunched that day. It came out of dried goats' skins, with the hairs left on and turned inside (ä $\sigma \kappa \circ)$; this gives it a strong flavour, suggestive of goats, which nearly made me sick; but it seemed to please Papa Demetrios, who drank of it freely and grew very gay. He proposed I should stay a very long time at Amorgos, and that he would take me to shoot wild goats on Mount Krytelos, that distant peak to the north of the island, far away from houses or civilisation; and when the summer came we could sleep in the open and have rare sport. But I could only give him the indefinite promise

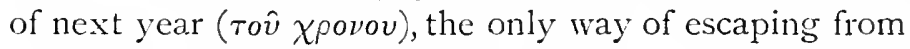
these pressing invitations of hospitality.

Apropos of sport, the priest asked me the following riddle, to which, I am ashamed to say, I had to be told the answer was a spider:-

I live on all sorts of sport, yet I never go up to the mountain forests ;

I weave nets, and I set them, yet I am not a fisherman; I am found with the poor, yet I am by no means a pauper, And with the offspring of poverty I provide dinner for my belly.

The mountain village at which we lunched rejoiced in the long name of Asphondilitis ; it is given to cheesemaking, and composed of hovels. The one in which we halted was full of cheeses drying on reeds, which were hung from the wall so as to form shelves, and which they call каланакі́. At this village the old men wear 
an ancient costume consisting of a curious waistcoat on stomacher and the red skoupliza, a knitted cap, which hangs down on one sicie and which their wives make for them at home, spinning the material and dyeing it with a sort of berry they find on the hills. We visited another ancient tower, and it was quite late before we reached Amorgos and the demarch's comfortable quarters.

All writers of antiquity agree in saying that Amorgos was three-citied ( $\tau \rho i$ mo $\lambda \iota s$ ): they were Aigiale, the ruins

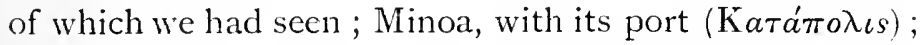
and Arkesini. Each of these towns has been identified by inscriptions found in them; also these inscriptions further tell us that Minoa was a colony from Samos, and Aigiale a Milesian colony. Papa Demetrios proposed that on the next day we should start early, visit Minoa and Arkesini, amongst the ruins of which his father lived and he had been brought up, pass the night at a hamlet called Brytzi, visit the Hellenic tower, and return home on Friday-Good Friday, that is to say. It was a hard programme, as mules could not go along the road he proposed to take me.

First of all, very early in the morning we descended to the harbour (Katapolis), and there Papa Demetrios showed me the remains of a temple of Pythian Apollo, now only discernible from certain pedestals and inscriptions, some of which stand in a field near the shore, and others are let into the building of a little church, the Virgin of the Hundred Gates. On the steps before the tempelon of this church there is a slab, inscribed in late Greek letters, which states that it was put up in honour of one Aurelius, of Minoa; there are others about, one of which is in honour of a Roman emperor, another to Dionysos, another to Hera; by far the most are of Roman date. A little way along the coast we came 
upon a number of vaulted chambers (tholaria) built up against the cliff, undoubtedly Roman tombs, containing three or four graves in each. Over each grave is the niche for glass vases and lamps, and over each lintel is a rounded arch of white marble, on which has been an inscription, now obliterated. The natives, for the most part, use them as stalls for cattle and storehouses for wood, and look upon them with superstitious awe.

We then climbed the summit on which Minoa once stood, about 600 feet above the sea-level, and we were much struck with the size of the walls and the extent of the terraces; the entrance to this inner town is easily traced, and inside these are numerous cisterns. One curious subterranean building puzzled us much; it has been approached by two doors and steps downwards. The chamber to which they conducted was six feet high, about two yards square, and roofed in by two huge slabs. Over the doors were two deep recesses, and on two sides of this chamber were stone benches raised about a foot and a half from the floor, and in these benches were round holes, open at the outer edge, which looked as if they had been intended for holding those large amphore. Below this chamber was another, of apparently the same nature, but so filled with rubbish that we could make no observations.

Not many yards from this were the remains of a big building, of which only one wall was left, and slight traces of a vaulted roof, and just outside it extended a flat space, supported on the outer side by a huge wall, which may have been the stadium. On the southern slope of the eminence is the ancient necropolis, many of the graves of which are still unopened. Down in the valley bencath was a stream, or rather the dry bed of what once probably had been a stream, for it is walled in by ancient 
constructions, now useless, but which doubtless were intended to protect the neighbouring fields from being washed away; all about here are traces of ruins, for the most part turned into cattle stalls. There we saw what had once been the legs of a beautiful statue and several ancient inscriptions let into the walls.

On leaving Minoa we climbed a hill, and halted for our midday repose at a quaint farmhouse. The formation of the room we entered was primitive : a little low table about a foot high, with stools all round, off which we fed; a lamp fixed to a piece of wood nailed on to a block, which could be carried about at will; all round the wall ran a shelf, like a frieze, decorated with the household gods; old plates, of the Venetian epoch, mixed, with bright pottery from the Dardanelles; in one corner stood a table on which, by way of ornament, was placed a red dried gourd and an abortive lemon; and the walls were decorated with those rude religious pictures, a large number of which found their way into Greece a few years back from Russia, when that country hoped, on the score of religion, to get a footing here.

Hung up against the wall was the goatskin bag for carrying luggage when the son of the house, a fine, stalwart youth dressed in homespun clothes, went on a journey to the town : it was of very simple construction, having wooden corks put into the feet, sewn up the middle, and strings, or rather thongs made out of cut skin, for hanging it over the shoulder, passed through a bone with which to draw it tight: this is the bouria. Then there was the kaphisisi for measuring barley.

The old woman and her grandchild sat plucking cotton as we entered. They seemed much pleased to see us, and under Papa Demetrios' wing there was no fear of our not being most hospitably treated; and at his 
instigation the old crone told us some quaint stories, the effect of which was enhanced by her huge white tourlos, which nodded mysteriously as she related how an evil spirit lived close by, which now and again rises out of the sea and seizes infants; hence it is called Gialò (from yuàìs, the sea). If a child has been afflicted by it the mother first sends for the priest to curse the demon, and scratches her child with her nails; if these plans do not succeed she has to go down at sunset to the shore, and select forty round stones brought up by forty different waves; these she must take home and boil in vinegar, and when the cock crows the evil phantom will disappear and leave the child whole.

After a walk of two more hours we approached the rocky promontory on which Arkesini was built: it is a splendid position-a rocky spur running out into the sea, and protected on all sides by lofty mountains. The spot is now called Kastri, but plenty of inscriptions have been found here to identify it as the ancient Arkesini; and it is the property of the father of Papa Demetrios, an old man of eighty, who tills the ground, and, as he does so, rakes up numerous archæological treasures for his son.

We entered the lowly abode, just under the rock, where the old man was sitting carving himself a wooden spoon, and surrounded by his implements of husbandry -his plough, his sickle, his two-pronged hoe for trimming his vines, still called in Amorgos the $\delta i^{\prime} \kappa \lambda a$ (in Sophocles the same instrument is referred to as a $\delta$ i $\kappa \lambda \lambda \lambda a$ ).

Our priest, on entering his father's house, touched the ground with his fingers, as a token of respect, before embracing him. His sisters, on the contrary, touched the ground with their fingers before kissing the proffered hand of their brother. This mode of greeting a priest is 
common now only in primitive societies in Greece, as is also the old way of greeting by placing the hand on

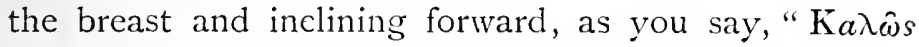

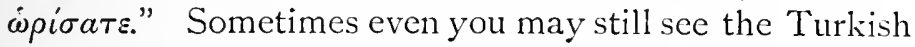
fashion carried out, of putting the hand first to the lips and then to the forehead.

Into the crannies of the stone wall the old man had stowed away a lot of the antiquities that had come to hand recently whilst digging. These he generously placed at my disposal ; and, before we left, he gave us a pull at his raki-bottle, drinking first himself, according to the old custom, to prove that his liquor was not poisoned.

Papa Demetrios then personally conducted me over the ruins, every stone of which he knew by heart, for he had been born and bred in their very midst. Though not very extensive, the ruins of Arkesini are interesting, and the rock on which they stand recalls in miniature the Athenian acropolis. There are still to be seen stairs and terraces right down to the sea, and the ascent to the summit is only by one narrow path, which we should have had some difficulty in finding without a guide. Papa Demetrios took great pride in showing us his father's work.

'Is not that a credit to an old man of eighty?' he said, pointing to a nearly-made partition-wall. 'Do you think it will last as long as that?' drawing our attention to a colossal Hellenic structure as he laughed at his own joke. There are traces, too, of medixval work on the summit, and lots of little stone houses, where Papa Demetrios told us the guests from the town used to sleep when they came here on the annual festival in honour of the Madonna of Kastriani; but this has been abandoned of late years, though the church is still kept in 
good repair. The walls have plenty of inscriptions let into them, and all around are the foundations of ancient houses and pieces of what have been good statues, most of them piled together in a shed by the old man, and from amongst which I chose a thing or two that pleased me.

Towards evening we bade farewell to the old man and climbed up to the village of Brytzi, where we were to pass the night. It consists of about fifteen houses clustered together, and on a rock in the middle of them are some of those singular writings cut in half-Phœnician, half-Greek letters, similar to some which we had seen on wur return from Aigiale; these archaic letters are peculiar to the islands. There is a local proverb about the hospitality of this place: "Whoso goeth to Brytzi and does not get drunk is like a pilgrim who goeth to the Holy Sepulchre and doth not worship ; ' and this hospitality of Brytzi was no empty boast, for on our arrival under the roof of a friend of our guide's the neighbours flocked in with provender-one with eggs, another with wine, another with bread, and finally our host came in with a little pig, which he killed, skinned, and roasted before ur longing eyes. As he brought it into the house he made a curious obeisance and placed the pig at my feet, saying as he did so a little distich, 'I have brought you a little pig, red, red as your beard ;' and noting my astonishment and the absence of any red beard, Papa Demetrios explained that this was a customary way of offering a like present to a guest whom they wished to honour.

After dinner we had music, singing, and dancing to the tune of a primeval lyre ; and on the morrow, when we left, not a penny would our host take for all this hospitality, and under circumstances such as this did I 
realise the benefit of having taken with me a stock of English penknives, \&c. : the people prized them highly as returns for hospitality.

Next morning we walked a good distance farther southwards, to see the celebrated watch-tower of Amorgos, which is one of the best specimens of Hellenic art preserved. It is situated in the centre of a fertile valley, and is known by the name of 'sto Choriò ('to the place'), or the tower of Holy Trinity. The hamlet around it climbs up the mountain behind, and forms a picturesque background to the tower; and then there are traces of other towers in the immediate vicinity, which shows what an important position this once must have been, commanding not only a fertile space, but also the easiest approach to Arkesini.

As is usual with these towers, there is a legend attached, and the peasants tell you that years ago there lived a lovely woman whose suitors were many, and she promised her hand to the one who would build her the finest tower. Whereupon all the aspirants set to work to build towers, and in this way not only are the number of towers in Amorgos accounted for, but also the superiority of this, for she chose the builder of it, and came to live here herself.

There is an outer wall surrounding a courtyard, all built of the blue granite of the island. This wall is about a yard thick, and some of the stones in it are from six to eight feet long and three feet high; but, as usual, the lower courses of stones are larger than the higher ones. The wall is highly picturesque, with wild mastic and other shrubs growing on it.

Inside the courtyard is the tower itself-square, and in parts still thirty feet high-and the walls of it have several loopholes for shooting out of, about three or four 
feet high, and on the inside nearly a yard wide, but presenting an cxternal opening of little over threc or four inches. To the west is a window about a yard and a half wide, the only way in which any appreciable amount of light can have been introduced into the building. Unfortunately, it is impossible now-as in the tower of Andros ' - to form any idea of what the interior was like, for it is a mass of stones and rubbish, which have fallen from above. There are two cisterns in connection with the tower, one about fifty feet from it, hewn in the natural rock, and the other across the valley, with a conduit to the tower. Unfortunately there are a lot of cattle-sheds built up against the tower, which prevented us from seeing the extent of its outworks; but the old Hellenic walls extend in various directions from the outer wall, and point to extensive fortifications around, or to the existence of houses built under the protecting wing of the tower.

In one of these adjoining sheds we came across a raki distillery, and were treated by the owner to some excellent wine. In the village church, dedicated to the Holy Honophrius, we found a long inscription, which told us that in ancient times an agreement had been entered into between the priests of a temple of Zeus Temenetos near here, and the husbandmen who farmed the sacred lands, for the supply of grapes, figs, and other produce as a sort of rent.

On the other side of the valley is a village called Rakide, presumably from the good raki which they made there. It contains many inscriptions, and the remains of another tower; in fact, this part of Amorgos must have been extremely populous in ancient days.

On our return to the capital we passed through a wild, uncultivated district with lovely views over the hills 
and sea, and we were thankful to reach our quarters again, for this travelling in mountain hamlets is not conducive to comfort, and we were anxious to join in the coming festivities of Easter week.

The town of Amorgos itself does not present many interesting features for the archæologist; the churches are bare, and the houses have but rude attempts at decoration, but most of them contain many interesting relics of the Venetian days, oak chests, embroideries and pottery. There are, too, a considerable number of olivepresses here, primitive in construction, for the modern improvements which have penetrated into other parts of olive-growing Greece have not reached here yet. They consist of flat stones with a circular rim; on to this the olives.are put in bags and pressed with another stone until the oil runs out into the rim, and from thence into a receptacle placed for it. Two men usually turn the upper stone by means of wooden screws and iron bars, though sometimes mules are employed for this purpose. I fancy that the olive-presses now in use in Amorgos are not very different from those which their forefathers used centuries before our era. 



\section{BOOKS OF TRAVEL AND ADVENTURE.}

\section{WORKS BY LADY BRASSEY.}

A VOYAGE IN THE 'SUNBEAM,' our Home on tho Ocean for Eleven Months.

Library Edition, with 7 Maps and

118 Illustrations, 8 vo. $21 s$.

Cabinet Edition, with Map and 65 Illustrations, erown 8 vo. $7 s .6 d$.
School Edition, with 37 Illustra tions, fep. $2 s$.

Popular Edition, with 60 Illustrations, 4to. $6 d$.

SUNSHINE AND STORM IN THE EAST; or, Cruises to Cyprus and Constantinople. With 2 Maps and 114 Illustrations engrared on Wood.

Library Edition, 8ro. 21s.

Cabinet Edition, crown 8ro. 7s. $6 d$.

IN THE TRADES, THE TROPICS, and THE 'ROARING FORTIES'; or, Fourteen Thousand Miles in the Sunbeam in 1883. With nearly 250 Illustrations engraved on Wood from drawings by R. T. Pritchetr, and 8 Maps and Charts.

Édition de Luxe, 1 vol. imperial Sro. price Three Guineas and a Half (only 250 copies printed).

Library Edition, 1 vol. 8ro. price One Gainea.

RANCH NOTES IN KANSAS, COLORADO, THE INDIAN TERRITORY, AND NORTHERN TEXAS. By Regivald Aldridge. Crown 8ro. with 4 Illustrations ou Wood by G. Pearson, $5 s$.

London: LONGMANS, GREEN, \& CO. 
EIGHT YEARS IN CEYLON. By Sir SAMUEL W. BAker, M.A. Crown 8vo. Woodeuts. 5i.

THE RIFLE AND THE HOUND IN CEYLON. By Sir Samuel W. Baker, M.A. Crown 8ro. Woodcuts. 5s.

SOME IMPRESSIONS OF THE UNITED STATES. By E. A. Freeman, D.C.L. Crown 8 ro. $6 s$.

SAN REMO, Climatically and Medically considered. By Arther Hill Hassali, MI.D. With 30 Illustrations. Crown Sro. $5 s$.

WINTERING IN THE RIVIERA. With Notes of Travel in Italy and France, and Practical Hints to Travellers. By W. Miller. With 12 Illustrations. Post 8ro. 7s. $6 d$.

THREE IN NORWAY. By Two of Thexr. With a Mip and 59 Illustrations on Wood from Sketches by the Authors. Crown 8 ro. $6 s$.

ACROSS THE PAMPAS AND THE ANDES: being an decount of an Exploring and Surveying Expedition across the Continent of South America. By Ropert Crawford, Mi.A. Professor of Civil Engineering in the University of Dublin. With a Map and Illustrations. Crown 8ro. 7s. 6d.

London: LONGMANS, GREEN, \& CO. 


\section{LORD MACAULAY'S WORKS.}

\section{AUTHORISED EDITIONS.}

HISTORY of ENGLAND, from the ACCESSTON of JAMES the SECOND :-

Student's Fdition, 2 vols. crown 8vo. $12 s$.

People's Edition, 4 vols. crown 8vo. $16 s$.

Cabinet Edition, 8 vols. post 8 vo. 48 s.

Library Edition, 5 vols. 8vo. $£ 4$.

CRITICAL and HISTORICAL ESSAYS with LAYS of ANCIENT ROME, in One Volume:-

Authorised Edition, crown 8vo. 2s. 6d. or 3s. 6il. gilt edges.

Popular Edition, crown 8vo. 2s. $6 d$.

\section{CRITICAL and HISTORICAL ESSAYS :-}

Student's Edition, 1 vol. crown Sro. 6s.

People's Edition, 2 vols. crown 8 vo. $8 s$.

Cabinet Edition, 4 vols. post 8vo. 24 s.

Library Edition, 3 vols. 8vo. $36 s$.

ESSAYS, which may be had separately, price 6d. each sewed, 1s. each cloth :Addison \& Walpole.

Frederick the Great.

Croker's Boswell's Jolnson.

Hallam's Constitutional History.

Warren Hastings,

The Earl of Chatham (Two Essays).

Ranke « Gladstone.

Milton \& Hachiavelli.

Lord Bacon.

Lord Clive.

Lord Byron \& The Comic Dramatists of the Restoration.

The Essay on Warren Hastings annotated by S. Hales, $1 s .6 d$.

The Essay on Li rd Clive annotated by H. Courthope-Bowen, M.A. 2s. $6 d$.

\section{LAYS of ANCIENT ROME :-}

Illustrated by G. Scharf, fep. 4to. 10s. $6 d$.

sewed, 1s. cloth.

Popular Edition, fep. 4to. $6 d$.

Illustrated by J. R. Weguelin, crown 8vo. 3s. 6cl. cloth extra, gilt edges.

Cabinet Edition, post 8vo. 3s. 6d.

Annotated Edition, fcp. 8vo. 1s. sewed; 1s. 6u. cloth, or 2s. 6d. cloth extra, gilt edges.

London: LONGMANS, GREEN, \& CO. 


\section{IORD MACAULAY'S WORKS AND LIFE.}

\section{AUTHORISED EDITIONS.}

SPEECHES, corrected by Himself :-

People's Edition, crown 8vo. 3s. 6d.

\section{MISCELLANEOUS WRITINGS :-}

Library Edition, 2 vols. 8vo. Portrait, $21 s$.

People's Edition, 1 rol. crown 8vo. $4 s .6 d$.

\section{MISCELLANEOUS WRITINGS and SPEECHES :-}

Student's Edition, in ONe Volume, crown 8vo. price cs.

Cabinet Edition, including Indian Penal Code, Lays of Ancient Rome, and Miscellaneous Poems, 4 vols. post 8ro. $24 s$.

\section{The COMPLETE WORKS of IORD MACAULAY.}

Edited by his Sister, Lady Trevelyax.

Library Edition, with Portrait, 8 vols. demy 8vo. £5. 5 s.

Cabinet Edition, 16 vols. post 8vo. $£ 4$. 16 s.

SELECTIONS from the WRITINGS of LORD MACAULAY. Edited, with Occasional Notes, by the Right Hon. G. O. Trevelyas, M.P. Crown 8ro. 6s.

\section{The LIFE and LETTERS of LORD MACAULAY.}

By the Right Hon. G. O. Trevelyax, M.P.

Popular Edition, 1 vol. crown 8vo. 6s.

Cabinet Edition, 2 vols. post 8ro. $12 s$.

Library Edition, 2 vols. 8vo. with Portrait, $36 s$.

London: LONGMANS, GREEN, \& CO. 


\section{BIOGRAPHICAL WORKS, REIIINISCENCES, \&C. RECENTLY PUBLISHED.}

REMINISCENCES. By Thomas Carlyle. Edited by J. A. Froude, M.A. 2 rols. crown 8 ro. $18 s$.

THOMAS CARLYLE : a History of the First Forty Years of his Life, 1795 to 1835 . By J. A. Frodde, M.A. With 2 Portraits and 4 Illustrations. 2 rols. 8 ro. $32 s$.

THOMAS CARLYLE : a History of his Life in London, 1834 to 1881. By James A. Frodde, M.A. With Portrait engraved on Steel. 2 vols. 8 ro. $32 s$.

LETTERS and MEMORIALS of JANE WELSH CARLYLE. Prepared for publication by Thomas CARLYLe, and Edited by J. A. Frodde, M.A. 3 vols. 8 ro. 36 s.

REMINISCENCES chiefly of TOWNS, VILLAGES, and SCHOOLS. By the Rev. Thomas Mozuer, M.A. Author of 'Reminiscences of Oriel College and the Oxford Movement.' 2 vols. crowri. 8 ro. $18 s$.

The STRANGE CAREER of the CHEVALIER D'EON DE BEAUMONT, Ninister Plenipotentiary from France to Great Britain in 1763 . By Captain J. Buchan Trlfer, R.N. F.S.A. F.R.G.S. Author of 'The Crimea and Transcancasia,' The Bondage and Travels of Johann Schiltberger,' \&c. 8ro. with 3 Portraits, $12 s$.

* * This History of the Chevalier D $D^{*}$ Eon de Beaumont, whose sex was a mystery for upwards of forty years, is treated from original MSS. and other unpublished documents, and French official despatches in the works of Flassan, Loménie, Gaillardet, Boutaric, the Duke do Broglie, and Vandal.

LOUIS PASTEUR: his Life and Labours. By his Son-INLaw. Translated from the French by Lady Cuaud Hamilton. Crown 8 vo. $7 s .6 d$.

*** In this work the Author relates in much detail the history of M. Pasterr's discoreries, and furuishes many lively biographical anecdotes. The translation is produced under the superintendence of Prof. Tyndall.

MEMOIR of COUNT GIUSEPPE PASOLINI, late Presideut of the Senate of Italy. Compiled by his Son. Translated and Abridged by the Dowager-Countess of Dalmousie. With Portrait. Sro. $16 s$.

PHASES of OPINION and EXPERIENCE DURING a LONG LIEE: an Autobiography. By Charles Brar, Author of 'The Philosophy of Necessity' \&c. Crown 8vo. 3s. $6 d$.

London: LONGMANS, GREEN, \& CO. 


\section{STANDARD HISTORICAL WORKS.}

\section{By Lord MACAULAY.}

HISTORY of ENGLAND from the ACCESSION of JAIIES II.

STUDENT's EoITION, 2 vols. crown 8vo. $12 s$.

PFOILE'S EUITION, 4 vols. crown 8 vo. $16 s$.

CABinet EutTion, 8 vols. post 8 ro. price $48 s$.

Library EdiJiox, 5 vols. Svo. 44 .

\section{BY JAMES A. FROUDE.}

HISTORY of ENGLAND from

the Fall of Wolsey to the Defeat of

the spanish Armada.

Popllar EDITIOx, 12 vols. crown Svo. $\pm 2.2 s$.

CABIVET Edition, 12 vols. crown Svo. $£ 3$. I2s,

The ENGLISH in IRELAND in the Eightcenth Century. 3 vols. crown 8vo. $18 s$.

\section{By S. R. GARDINER.}

HISTORY of ENGLAND from the ACCESSION of JAMES I. to the OUTBREAK of the GREAT CIVIL WAR. Cabinet Edition, in Ten Volumes, crown 8vo. 6s, each.

By W. E. H. LECKY.

HISTORY of ENGLAND in the Eiglteenth Century. 4 vols. 8vo. $17(n-1784$. E.3. 12s.

The HISTORY of EUROPEAN MOIAAIS from AUGUSTUS to CHARLEMAGNE. 2 vols. crown 8vo. $16 s$.

HISTORY of the RISE and Influence of the Spirit of Rttionalism in Europe. 2 vols. crown 8vo. price $16 s$.

\section{By Sir T. ERSKINE MAY.}

The CONSTITUTIONAL HISTOIY of WNGIAND since the ACCESSION of GEORGE III. 17601870.3 vols, crown 8vo. $18 s$.

$D E M O C R A C Y$ in EUROPE: a History. 2 vols. 8 ro. $32 s$.

\section{By A. DE TOCQUEVILLE.}

DEMOCRACY IN AMERICA, translated by $H$. REEve. 2 vols. crown 8vo. $16 s$.

\section{By H. T. BUCKLE.}

HISTORY of CIVILISATION in Hnglani and France, Spain and Scotland. 3 vols, erown Svo, $24 s$.

By the Rev. M. CREIGHTON. HISTORY of the PAPACY during the IREFORII TION. Vols. I. \& II. 1378-1464. 2 vols. 8vo. 32s.

\section{BY EDWARD A. FREEMAN.}

The HISTORICAL GEOGRAPHY of EUROPE. With 65 Maps. 2 vols. 8 vo. $31 s .6 d$.

\section{By Dean MERIVALE.}

HISTORY of the ROMANS under the EIIPIRE. 8 vols. post 8 ro. $48 s$.

\section{BY SPENCER WALPOLE.}

HISTORY of ENGLAND from the Conclusion of the Great War in 1815 to the Year $18+\mathrm{I}$. 3 vols. 8 to. price $£ 2$. I $4 s$.

\section{By Sir W. S. MAXWELL.}

DON JOHN of AUSTRIA; or, Passages froni the History of the Sixteruth Century, 1547-1578. With numerous Illustrations engraved on Wood, taken from Autbentic Cortemprorary sources. Library Eitition. 2 vols. royal 8 vo. $42 s$.

\section{By G. H. LEWES.}

The HISTORY of PHILOSOPHY, from 'fliales to Comte. 2 vols, 8 vo. price $32 s$.

\section{By Prof. G. RAWLINSON.}

The SEVENTH GREAT ORIENTAL MONARCHY; or, a History of the Sinsanians. With Map and 95 Illustrations. 8 ro. $28 s$. 


\section{JUIY 1884. \\ GENERAL LISTS OF WORKS \\ PUBLISHED BY}

\section{Messrs. LONGMANS, GREEN, \& CO.}

\section{PATERNOSTER ROW, LONDON.}

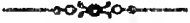 \\ HISTORY, POLITICS, HISTORICAL MEMOIRS, \&C.}

Arnold's Lectures on Modern History. $8 \nabla 0,7 s, 6 d$.

Bagehot's Literary Studies, edited by Hutton. 2 vols, 8ro. 28 s.

Beaconsfield's (Lord) Speeches, by Kebbel. 2 vols. 8ro. 32s.

Bramston \& Leroy's Historic Winchester. Crown 8vo. $6 \mathrm{~s}$.

Bucklo's History of Givilisation. 3 vols. crowa 8vo. 24s.

Chesney's Waterloo Lectares. 8ro. 10s. 6d.

Cox's (Sir G. W.) General History of Greece. Crown 8vo. Maps, 7s. $6 d$.

Doyle's English in America. 8ro. 18s.

Epochs of Anoient History :-

Beesly's Graccbi, Marius, and Sulla, 2s. 6d.

Capes's Age of the Antonines, 2s. $6 d$.

- Early Roman Empire, 2s. 6d.

Oox's Athenian Empire, 2s. $6 d$.

- Greeks and Persians, 2s. $6 d$.

Curteig's Rise of the Macedonian Empire, 2s. $6 d$.

Ihne's Rome to its Capture by the Gauls, 2s. 6d.

Merivale's Roman Triumvirates, 2s. $6 d$.

Sankey's Spartan and Theban Supreneacies, 2s. 6d.

Smith's Rome and Carthage, the Punic Wars, 2s. $6 d$.

Epochs of English History, complete in One Volame. Fcp. 8vo.5s.

Browning's Modern England, 1820-1874, 9d.

Creighton's Shilling History of England (Introductorg Volnme). Fcp. 8vo. 1s.

Creighton's (Mrs.) England a Continental Power, 1066-1216, 9d.

Creighton's (Rev. M.) Tudors and the Reformation, 1485-1603, $9 d$.

Gardiner's (Mrs.) Struggle against Absolute Monarchy, 1603$1688,9 d$.

Rowley's Rise of the People, 1215-1485, 9d.

Rowley's Settlement of the Constitution, 1689-1784, $9 d$.

Tancock's England during the American \& Earopean Wars, $1765-1820,9 d$.

York-Powell's Early England to the Conquest, 1 s.

Epochs of Modern History :-

Chnrch's Beginning of the Middle Ages, 2s.6d.

Cox's Crusades, 2s. $6 d$.

Creighton's Age of Elizabeth, 2s. 6d. [Continued on page 2.

London, LONGMANS \& CO. 
Epochs of Modern History-continued.

Gairdner's Houses of Lancaster and York, 2s. 6d.

Gardiner's Puritan Revolution, 2s. 6d.

- Thirty Years' War, 2s. 6d.

- (Mrs.) French Revolution, 1789-1795, 2s. 6d.

Hale's Fall of the Stuarts, 2s. $6 d$.

Johnson's Normans in Europe, $2 s .6 d$.

Longman's Frederick the Great and the Seven Years' War, 2s. 6d.

Ludlow's War of Amerlean Independence, 2s. $6 d$.

M'Carthy's Epoch of Reform, 1830-1850, 2s. 6d.

Morris's Age of Queen Anne, 2s. $6 d$.

Seebohm's Protestant Revolution, 2s. 6 d.

Stubbs's Early Plantagenets, 2s. 6 d.

Warburton's Edward III., 2s, $6 d$.

Froude's English in Ireland in the 18th Century. 3 vols. crown 8vo. 18s.

- History of England. Popular Edition. 12 vols. crown 8vo. 3s. 6d. each. Gardiner's History of England from the Accession of James I. to the Outbreak of the Civil War. 10 vols. crown 8 vo. 60 s.

- Outline of English History, в.c. 55-A.D. 1880. Fcp. 8vo. 2s. 6d.

Grant's (Sir Alex.) The Story of the University of Edinburgh 2 vols. 8vo. $36 \mathrm{~s}$. Greville's Journal of the Reigns of George IV. \& William IV. 3 vols. 8vo. $36 s$.

Hickson's Ireland in the Seventeenth Century. 2 vols. 8vo. $28 s$.

Lecky's History of England. Vols. I. \& II. 1700-1760. 8vo.36s. Vols. III. \& IV. 1760-1784. 8ro. 36s.

- History of European Morals. 2 vols. crown 8vo. 16s.

- - - Rationalism in Europe. 2 vols, crown 8vo. 16.

Lowes's History of Philosophy. 2 vols. 8vo. 32s.

Longman's Lectures on the History of England. 8vo. 158.

- Life and Times of Edward III. 2 vols. 8vo. 28s.

3acaulay's Complete Works. Library Edition. 8 vols. 8vo. \&5. 58.

- - - Cabinet Edition. 16 vols. crown 8vo. \$4. 16.

- History of England :-

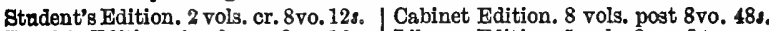

People's Edition. 4 vols. cr. 8vo. 16s. Library Edition. 5 vols. 8vo. \&4.

Macanlay's Critical and Historical Essays. Cheap Edition. Crown 8vo, 2s.6d.

Stadent's Edition. 1 vol.cr. 8vo. 6s. |Cabinet Edition. 4 vols. post 8vo. 24s.

People's Edition. 2 vols. cr. 8vo. 8s.

Maxwell's (Sir W. S.) Don John of Austria. Library Edition, with numerous Illustrations. 2 vols. Royal 8vo. $42 s$.

May's Constitutional History of England, 1760-1870, 3 vols, crown 8vo. 18s.

- Democracy in Europe. 2 vols. 8vo. $32 s$.

Merivale's Fall of the Roman Republic. 12mo. 7s. $6 d$.

- Generel History of Rome, B.c. 753-A.D. 476. Crown 870. 7s. 6d.

- History of the Romans under the Empire. 8 vols. post 8vo. 48s.

Rawlinson's Seventh Great Oriental Monarchy-The Sassanians. 870. 28s.

Seebohm's Oxford Reformers-Colet, Erasmus, \& More. 8vo. 14s.

Short's History of the Church of England. Crown 8vo. 7s, 6d.

Smlth's Carthage and the Carthaginians. Crown 8vo. 10s. $6 d$.

Taylor's Maraul of the History of India. Crown 8vo. 7s. 6d.

Trevelyan's Early History of Charles James Fox. Crown 8vo. 6s.

Walpole's History of Kngland, 1815-1841. 3 rols. 8vo. 22.14 .

London, LONGMANS \& CO. 


\section{BIOGRAPHICAL WORKS.}

Bagehot's Biographical Studies. 1 vol. 8vo.12s.

Bain's Biography of James Mill. Crown 8vo. Portrait, 5s.

- Criticism and Recollections of J. S. Mill. Crown 8vo. 2s. 6d.

Oarlyle's Reminiscences, edited by J. A. Frcode. 2 vols. crown 8vo. 18 \&.

- (Mrs.) Letters and Memorials. 3 vols. 8 ro. $36 s$.

Cates's Dictionary of General Biography. Medium 8vo. 28s.

Froude's Luther, a short Biography. Cromn 8ro. 1s.

- Thomas Carlyle. Vols, 1 \& 2, 1795-1835. 8vo. with Portraits and Plates, 32s.

Gleig's Life of the Duke of Wellington. Crown 8vo. Bs.

Halliwell-Phillipps's Outlines of Shakespeare's Life. 8vo. 7s. 6d.

Lecky's Lexders of Public Opinion in Ireland. Crown 8vo. 7s. 6d.

Life (The) and Letters of Lord Macaulay. By his Nephew, G. Otto Trevelyan,

M.P. Popular Edition, I vol. crown 8vo. 6s. Cabinet Edition, 2 vols. post

8vo. 12s. Library Edition, 2 vols. 8vo. 36s.

Marshman's Memoirs of Havelock. Crown 8vo. 3s. $6 d$.

Mendelssohn's Letters. Translated by Lady Wallace. 2 vols. cr. 8vo. 5s. each.

Mill's (John Stuart) Antobiography. 8vo. 7s. 6d.

Mozley's Reminiscences of Oriel College. 2 vols, crown 8vo. $18 s$.

Newman's Apologia pro Vitâ Sua. Crown 8vo. Bs.

Skobeleff \& the Slavonic Cause. By O.K. 8vo. Portrait, 14 s.

Bouthey's Correspondence with Caroline Bowles. 8vo. 14s.

Spedding's Letters and Life of Francis Bacon. 7 vols. 8vo. £4. 4.

Stephen's Essays in Eoclesiastical Biography. Crown 8vo. 7s. $6 d$.

\section{MENTAL AND POLITICAL PHILOSOPHY.}

Amos's View of the Science of Jurisprudence. 870. 18s.

- Fifty Years of the English Constitution, 1830-1880. Crown 8vo. 10s. 6d,

- Primer of the English Constitution. Crown 8vo. 6s.

Bacon's Essays, with Annotations by Whately. 8vo. 10s. $6 d$.

- Promus, edited by Mrs. H. Pott. 8ro.16s.

- Works, edited by Spedding. 7 vols. 8vo. 73s. $6 d$.

Bagehot's Economic Studies, edited by Hntton. 8v0. 10s. $6 d$.

Bain's Logic, Dedactive and Inductive. Crown 8vo. 10s, $6 d$.

PART I. Deduction, 4s. i PART II. Induction, 6s. 6d.

Bolland \& Lang's Aristotle's Politics. Crown 87o. 7s, 6 d.

Grant's Ethics of Aristotle; Greek Text, English Notes. 2 vols. 8vo. 32s.

Hodgson's Philosophy of Reflection. 2 vols. 8ro. 21 s.

Kalisch's Path and Goal. 8vo. 12s. 6d.

Lealie's Essays in Political and Morai Philosophy. 8ro, 10s, $6 d$.

Lewis on Anthority in Matters of Opinion. 8vo. 14s.

Macanlay's Speeches corrected by Himself. Crown 8vo. 3s. $6 d$.

Macleod's Economical Philosophy. Vol. I. 8vo. 15s. Vol. II. Part I. 12..

Mill's (James) Analysis of the Phenomena of the Human Mind. 2 vols. 8vo. 28 s. Mill (John Stuart) on Representative Government. Crown 8vo. 2 s.

- $\rightarrow \quad$ on Liberty. Crown 8vo. 1s.4d.

Mill's (John Stuart) Dissertations and Discussions. 4 vols. 8vo. 46s. $6 d$.

London, LONGMANS \& CO. 


\section{General Lists of Works.}

Mill's (John Stuart) Essays on Unsettled Questions of Political Economy. 8vo. 6s. $6 a$.

- $\quad$ - Examination of Hamilton's Philosophs. 8vo. 16.

- - Logic, Ratiocinative aud Inductive. 2 vols. 8 ro. 25 s.

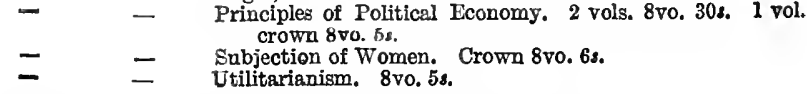

Miller's (Mrs. Fenwick) Readings in Social Economy. Crown 8vo. 5s.

Sandars's Institutes of Justinian, with English Notes. 870. $18 \mathrm{~s}$,

Seebohm's English Village Community. Evo. $16 s$.

Sully's Outlines of Psychology. 8ro. 12s. $6 a$.

Bwinbarne's Picture Logic. Post 8vo. 5s.

Thomson's Outline of Necessary Laws of Thought. Crown 8ro. 6s.

Tocqueville's Democracy in America, translated by Reeve. 2 vols. crown $8 \mathrm{ro} .16 \mathrm{~s}$.

Twiss's Law of Nations in Time of War. 8vo. 21s.

Whately's Ilcments of Logic. 8vo. 10s. 6d. Crown 8vo. 4s. $6 d$.

- - - Rhetoric. 8vo. 10s. 6d. Crown 8vo. 1s.6d.

- English Synonymes. Fcp. 8vo. 3s.

Williams's Nicomachean Ethics of Aristotle translated. Crown 8vo. 71. 6d.

Zeller's History of Eclecticism in Greek Philosophy. Crown 8vo. 10s. 6d.

- Plato and the Older Academy. Crown 8vo. 18s.

- Pre-Socratic Schools. 2 vols. crown 8vo. 30s.

- Socrates and the Socratic Schools. Crown 8vo. 10s. 6d.

- Stoics, Epicureans, and Sceptics. Crown 8vo. 15s.

\section{MISCELLANEOUS AND CRITICAL WORKS.}

Arnold's (Dr. Thomas) Miscellancous Works, 8vo, 7s, 6d.

- (T.) Manual of English Literature. Crown 8vo. 7s. 6d.

Bain's Emotions and the Will. 8vo. 15s.

- Mental and Moral Science. Crown 8vo. 10s. 6d.

- Senses and the Intellect. 8vo. 15s.

- Practical Essays. Crown 8vo. 4s. $6 a$.

Beaconsfield (Lord), The Wit and Wisdom of. Crown 8vo. 3s. $6 d$.

- (The) Birthday Book. 1Smo. 2s. 6d. cloth; 4s. 6d. bound.

Becker's Charicles and Gallus, oy Metcalfe. Post 8vo. 7s. 6d. each.

Blackley's German and English Dictionary. Post 8vo. 7s. 6d.

Contansean's Practical French \& English Dictionary. Post 8vo. 3s. 6 d.

Pocket French and English Dictionary. Square 18mo. 1s. 6d.

Farrar's Language and Languages. Crown 8vo. 6s.

French's Nineteen Centuries of Drink in England. Crown 8vo. 10s. $6 d$.

Fronde's Short Studies on Great Subjects. 4 vols, crown 8vo. 24s.

Grant's (Sir A.) Story of the University of Edinburgh. 2 vols, 8vo. $36 s$.

Hobart's Medical Langnage of St. Luke. 8vo. $16 s$.

Humo's Elsays, edited by Green \& Grose. 2 vols. 8vo. $28 \mathrm{~s}$.

- Treatise on Human Nature, edited by Green \& Groso. 2 vols. 8vo. 28s.

Latham's Handbook of the English Language. Crown 8vo. 6s.

Liddell \& Scott's Greek-Engligh Iexicon. 4to. 36s.

- Abridged Greek-English Iexicon. Square 12mo. 7s. 6d.

Longman's Pocket German and English Dictionary. 38mo. 5s.

Macanlay's Miscellaneous Writings. 2 vols. 8vo. 21 s. 1 vol. crown 8vo. 4s. $6 d$. - Miscellaneous Writings and Speeches. Crown 8vo. 6s.

- Miscellaneous Writings, Speeches, Lays of Ancient Rome, 80. Cabinet Edition. 4 vols. crown 8vo. $24 s$.

London, LONGMANS \& CO. 
Yahaffy's Classical Greek Literature. Crown 8vo. Vol. I. the Poets, 7s. 6d. Vol. II. the Prose Writers, 7s, 6 d.

Millard's Grammar of Elocution. Fcp. 8vo. 3s.6d.

Milner's Country Pleasures. Crown 8vo. 6s.

Mttller's (Max) Lectures on the Science of Language. 2 vols. crown 8vo. 16s.

- - Lectures on India. 8vo. 12s.6d.

Rich's Dictionary of Roman and Greek Antiquities. Crown 8vo. 7s. 6d. Rogers's Eclipse of Faith. Fcp. 8vo. 5s.

- Defence of the Eclipse of Faith Fcp. 8vo. 3s. 6d.

Roget's Thessurus of English Words and Phrases. Crown 8vo. 10s, 6d.

Selections from the Writings of Lord Macaulay. Crown 8vo. $6 \mathrm{~s}$.

Simoox's Latin Literature. 2 vols. 8vo. $32 s$.

Tyndall's Faraday as a Discoverer. Crown 8vo. 3s. $6 d$.

- Floating Matter of the Air. Crown 8vo. 7s. 6d.

- Fragments of Science. 2 vols. post $8 \mathrm{ro} .16 \mathrm{~s}$.

- Heat a Mode of Motion. Crown 8vo. 12s.

- Lectures on Light delivered in America. Crown 8vo, 7s. 6d.

- Lessons in Electricity. Crown 8vo. 2s. 6d.

- Notes on Electrical Phenomena. Crown 8vo. 1s. sewed, 1s.6d. cloth.

- Notes of Lectures on Light. Crown 8vo. 1s. sewed, 1s.6d. cloth.

- Sound, with Frontispiece \& 203 Woodcuts. Crown 8vo. 10s, 6d.

Von Cotta on Rocks, by Lawrence. Post 8ro. 14d.

White \& Riddle's Large Latin-English Dictionary. 4to. 21s.

White's Concise Latin-English Dictionary. Royal 8vo. 12s.

- Junior Student's Lat.-Eng. and Eng.-Lat. Dictionary. Sq. 12mo. 5s.

Separately $\{$ The English-Latin Dictionary, $3 s$.

Wit and Wisdom of the Rev. Sydney Smith, Crown 8vo. 3s. $6 d$.

Witt's Myths of Hellas, translated by F. M. Younghusband. Crown 8vo.'3s. 6d.

- The Trojan War. Fcp. 8vo.2s.

Wood's Btble Animals. With 112 Vignettex, 8vo, 10s. $6 d$.

- Common British Insects. Crown 8ro. 3s. $6 d$.

- Homes Without Hands. 8vo. 10s. 6d. Insects Abroad. 8vo. 10s, 6d.

- Insects at Home. With 700 Mllustrations. 8ro. 10s. $6 d$.

- Ont of Doors. Crown 8vo. 5s.

- Petland Revisited. Crown 8vo. 7s.6 6 .

- Strange Dwellings. Crown 8vo. 5s. Popular Edition, 4to. 6d.

Yonge's Finglish-Greek Lexicon. Square 12mo. 8s. 6d. 4to. 21s.

The Essays and Contributions of A. K. H. B. Crown 8 ro.

Autumn Holidays of a Country Parson. 3s. $6 d$.

Changed Aspects of Unchanged Truths. 3s. $6 d$.

Common-place Philosopher in Town and Country. 3s. $6 d$.

Counsel and Comfort spoken from a City Pulpit. 3s. $6 d$.

Critical Essays of a Country Parson. 3s. $6 d$.

Graver Thorghts of a Country Parson. Three Series, 3s. 6d. each,

Landscapes, Churcnes, and Moralities. 3s. $6 d$.

Leisure Hours in Town. 3s. $6 d$. Lessons of Middle Age. 3s. 6d.

Our Little Life. Essays Consolatory and Domestic. 3s. $6 d$.

Present-day Thonghts. 3s. $6 d$.

Recreations of a Country Parson. Three Series, 3s. 6d. each.

Seaside Musings on Sundays and Week-Days. 3s. $6 d$.

Sunday Afternoons in the Parish Church of a University City. 3s, $6 d$.

London, LONGMANS \& CO. 
ASTRONOMY, METEOROLOGY, GEOGRAPHY, \&C.

Freeman's Historical Geography of Europe. 2 vols. 8vo. 31s. 6 d.

Herschel's Outlines of Astronomy. Square crown 8vo. $12 s$.

Keith Johnston's Dictionary of Geography, or General Gazetteer. 8vo. 42s,

Merrifield's Treatise on Navigation. Crown 8vo. $5 s$.

Neison's Work on the Moon. Medium 8vo. 31s. $6 d$.

Proctor's Essays on Astronomy. 8v0. 12s. Proctor's Moon. Crown 8v0.10s, 6d.

- Larger Star Atlas. Folio, 15s. or Mlaps only, 12s.6d.

- Myths and Marvels of Astronomy. Crown 8vo. 6s.

- New Star Atlas. Crown 8vo. 5s. Orbs Around Us. Crown 8vo, 7s, 6d.

- Other Worlds than Ours. Crown 8vo. 10s. Bd.

- Sun. Crown 8vo.14s. Universe of Stars. 870.10s.6a.

- Transits of Venus, 8v0. 8s. 6d. Studies of Venus-Transits, 8vo. 5s.

Smith's Air and Rain. 8vo. 24s.

The Public Schools Atlas of Ancient Geography. Imperial 8vo. 7s.6d.

Web's' - Modern Geography. Imperial 870. 58.

\section{NATURAL HISTORY \& POPULAR SCIENCE.}

Allen's Flowers and their Pedigrees. Crown 8ro. Woodcuts, 7s. 6d. Araott's Elements of Physics or Natural Philosophy. Crown 8vo. 12s. 6d. Brande's Dictionary of Science, Literature, and Art. 3 vols. medium 8vo. 63 s. Decaisne and Le Maont's General System of Botany. Imperial 8vo. 81s. 6d. Dixon's Rural Bird Life. Crown 8vo. Illustrations, $5 s$.

Edmonds's Elementary Botany. Fcp. 8ro. 2s.

Evans's Bronze Implements of Great Britain. 8vo. 25s.

Ganot's Elementary Treatise on Physics, by Atkinson. Large crown 8ro. 168.

- Natural Philosophy, by Atkinson. Crown 8ro. 7s, 6d.

Goodere's Elements of Mrechanism. Crown 8vo. 6s.

- Principles of Mechanics. Crown 8vo. 6s.

Grove's Correlation of Physical Forces, 8vo. 15s.

Hartwig's Aerial World. 87o. 10s. 6d. Polar World. 87o. 10s. 6d.

- Sea and its Living Wonders. 870. 10s. 6d.

- Subterranean World. 8vo. 10s. 6d. Tropical World. 8vo. 10s. 6d.

Haughton's Six Lectures on Physical Geography. 870. 15s.

Heer's Primæral World of Switzerland. 2 vols. 8 ro. 12s.

Helm holtz's Lectures on Scientific Subjects. 2 vols. cr, 8vo. $7 s .6 d$. each.

Hallah's Lectures on the History of Modern Music. 8vo. 8s.6d.

- Transition Period of Musical History. 8ro. 10s. 6d.

Jones's The Health of the Senses. Crown 8vo. 3s. $6 d$.

Keller's Lake Dwellings of Switzerland, by Lee. 2 vols. royal $8 \mathrm{vo.} 42$.

Lloyd's Treatise on Magnetism. 8vo. 10s. 6d.

Loudon's Encyclopædia of Plants. 8v0. 42s.

Lubbock on the Origin of Civilisation \& Primitive Cordition of Man, 8ro. 18s. Macalister's Zoology and Morphology of Vertebrate Animals, 8vo. 10s. 6d. Nicols' Puzzle of Life. Crown 8ro. 3s. $6 d$.

Owen's Comperative Anatomy and Physiology of the Vertebrate Animalg. 8 vols. 8v0. 73s. 6d.

- Experimental Physiology. Crown 8vo. $5 s$.

Proctor's Light Science for Leisure Hours. 3 Series, crown 8v0. 7s. 6d. each.

Riverg's Orchard House. Sixteenth Edition. Crown 8v0. 5s.

- Rose Amateur's Guide. Fcp. 8vo. 4s. 6d.

Btanley's Familiar History of British Birds. Crown 8vo. 6s.

Swinton's Electric Lighting: Its Principles and Practice. Crown 8ro. 5s.

London, LONGMANS \& CO. 


\section{THE 'KNOWLEDGE' LIBRARY,}

\section{Edited by Richand A. Proctor.}

The Borderland of Science. By R. A. Proctor. Crown Svo.6s. Sciencs Byrrays. By R. A. Procior. Crown Sro. 6s.

The Poetry of Astronomy. By R. A. Proctor. Crown 8vo. 6s.

Nature Studies. Reprinted frum Knouledge. By Grant Allen, Andrew Wilson, \&c. Crown 8ro. 6s.

Leisure Readings. Reprinted from Knocledge. By Edward Clodd, Andrew Wilson, \&c, Crown 8ro. $6 s$.

The Stars in their Seasons. BF R. A. Proctor. Imperial 8vo. $5 s$.

\section{CHEMISTRY AND PHYSIOLOGY.}

Buckton's Health in the House, Lectures on Elementary Physiology. Cr. 87o. 28. Jago's Inorganic Chemistry, Theoretical and Practical. Fcp. 8vo. 2s. Kolbe's Short Text-Book of Inorganic Chemistry. Crown 8vo. 7s. 6d.

Miller's Memente of Chemistry, Theoretical and Practical. 3 vols. 8vo. Part I. Chemical Physics, 16s. Part II. Inorganic Chemistry, 24s. Part III. Organio Chemistry, price $31 s .6 d$.

Reynolds's Experimental Chemistry. Fop. 87o. Pt. I. 1s. 6d. Pt. II. 2s. 6d. Pt. III. 3s. 6d.

Tilden's Practical Chemistry. Fep. 8vo. 1s. 6d.

Watts's Dictionary of Chemistry. 9 vols. medium 8vo. £15. 2s. $6 d$.

\section{THE FINE ARTS AND ILLUSTRATED EDITIONS.}

Dreser's Arts and Art Manufactures of Japan. Square crown 8ro. 31s. 6d. Eastlake's (Lady) Five Great Painters. 2 vols. crowa 8vo. 16s.

- Notes on the Brera Gallery, Milan. Crown 8vo. 5s.

- Notes on the Louvre Gallery, Paris. Crown 8vo. 7s. 6d.

Hulme's Art-Instruction in England. Fcp. 8 ro. 3s. $6 d$.

Jameson's Sacred and Legendary Art. 6 rols. square crown 8vo.

Iegends of the Madonna. 1 vol. 21 s.

- - - Monastic Orders. 1 vol. $21 s$.

Z - - Saints and Martyrs. 2 vols. 31 s. $6 d$.

- - - Saviour. Completed by Lady Eastlake. 2 vols. 198.

Macanlay's Lays of Ancient Rome, illustrated by Scharf. Fcp. 4to. 10s.6d. The same, with $I v y$ and the $A r$ mada, illustrated by Weguelin. Crown 8vo. 3s.6d. Macfarren's Lectures on Harmony. 8vo. 12s.

Moore's Irish Melodies. With 161 Plates by D. Maclise, R.A. Super-royal 8vo. 21 s.

- Lalla Rookh, illustrated by Tenniel. Square crown 8vo. 10s. 6d.

New Testament (The) illustrated with Woodcuts after Paintings by the Early Masters. 4to. 21s. cloth, or 42s. morocco.

Perry on Greek and Roman Sculpture. With 280 Illustrations engraved on Wood. Square crown 8vo. 31s. $6 d$.

London, LONGMANS \& CO. 


\section{THE USEFUL ARTS, MANUFACTURES, \&C.}

Bourne's Catechism of the Steam Engine. Fcp. 8vo. 6s.

- Examples of Steam, Air, and Gas Engines. 4to. 70 s.

- Handbook of the Steam Engine. Fcp. 8vo. 9s.

- Recent Improvements in the Steam Engine. Fcp. 8vo. 6s.

- Treatise on the Steam Engine, 4to. 42s.

Oresy's Encyclopædia of Civil Engineering. 8vo. 258.

Culley's Handbook of Practical Telegraphy. 8vo. 16s.

Eastlake's Household Taste in Furniture, \&c. Square crown 8vo. 14s.

Fairbairn's Useful Information for Engineers. 3 vols, crown 8vo. 31s. $6 d$.

- Mills and Millwork. 1 vol. 8vo. 25s.

Gwilt's Encyclopædia of Architecture. 8vo. 52s.6d.

Kerl's Metallurgy, adapted by Crookes and Röhrig. 3 vols. 8vo. fs. 198.

London's Enoyclopædia of Agriculture. 8vo. 21s.

- - - - Gardening. 8vo. 218.

Mitchell's Mannal of Practical Assaying. 8vo. 31s. 6d.

Northcott's Lathes and Turning. 8vo. $18 \mathrm{~s}$.

Payen's Industrial Chemistry Edited by B. H. Paul, Ph.D. 8vo. 12s,

Plesse's Art of Perfumery. Fourth Edition. Square crown 8vo. 21s.

Sennett's Treatise on the Marine Steam Engine. 8vo. 21s.

Ure's Dictionary of Arts, Manufactures, \& Mines. 4 vols. medium 8ro. \&7. 7s.

Ville on Artificial Manures. By Crookes, 8vo. 21s.

\section{RELIGIOUS AND MORAL WORKS.}

Abbey \& Overton's English Church in the Eighteenth Century. 2 vols, 8vo. 36s. Arnold's (Rev. Dr. Thomas) Sermons. 6 vols. crown 870. 5s, each.

Blshop Jeremy Taylor's Entire Works. With Life by Bishop Heber. Zdited by the Rev. C. P. Eden. 10 vols, 8 vo. £5. 5s.

Boultbee's Commentary on the 39 Articles. Crown 8vo. 6s.

- History of the Church of England, Pre-Reformation Period. 8vo. 15s,

Bray's Edements of Morality. Fcp. 8ro. 2s. 6d.

Browne's (Bishop) Exposition of the 39 Articles, 8vo. 16.

Calvert's Wife's Manual. Crown 8vo. 6s.

Christ our Ideal. 8vo. 8s.6d.

Oolenso's Jectures on the Pentateuch and the Mosbite Stone. 8vo. $12 s$.

Colenso on the Pentateuch and Book of Joshua. Crown 8vo. 6s.

Conder's Handbook of the Bible. Post 8ro, 7s. 6d.

Conybeare \& Howson's Life and Letters of St. Paul :-

Library Edition, with all the Original Mlustrations, Maps, Landscapes on Steel, Woodcuts, \&cc. 2 vols. 4 to. $42 s$.

Intermediate Edition, with a Selection of Maps, Plates, and Woodcnts.

2 vols. square crown $8 \mathrm{vo} .21 \mathrm{~s}$.

Student's Edition, revised and condensed, with 46 Ilustrations and Maps.

1 vol, crown 8v0. 7s, $6 d$.

Crefghton's History of the Papacy during the Reformation. 2 vols, 8vo, 32s. Davidson's"Introduction to the Study of the New Testament. 2 vols. $8 \mathrm{vo}$. 30s. Edersheim's Life and Times of Jesus the Messiah. 2 vols. 8vo. 42s.

London, LONGMANS \& CO. 
Fllicott's (Bishop) Commentary on St. Paul's Epistles. 8vo. Galatisns, 8s. 6d. Ephesians, 8s. 6d. Pastoral Epistles, 10s. 6d. Philippians, Colcsssians and Philemon, 10s. 6a. Thessalonians, 7s. $6 d$.

killicott's Lectures on the Life of our Lord. 8vo. $12 s$.

Ewald's Antiquities of Israel, translated by Solly. 8vo. 12s.6d.

- History of Israel, translated by Carpenter \& Smith. 6 vols. 8vo. $79 \mathrm{~s}$.

Gospel (The) for the Nineteenth Century. 4th Edition. 8vo, 10s. 6d.

Hopkinis's Christ the Consoler. Fep. 8vo, 2s. 6d.

Jukes's New Man and the Eternal Life. Crown 8vo. 6s.

- Second Death and the Restitution of all Things. Crown 8vo.3s. $6 d$.

- Types of Genesis. Crown 8v0. 7s.6d.

Kalisch's Bible Studies. PaRT I. the Prophecies of Balaam. 8vo. 10s. 6d.

- - - PART II. the Book of Jonah. 870. 10s. 6d.

- Historical and Critical Commentary on the Old Testament; with a

New Translation. Fol. I. Genesis, 8vo. 18s. or adapted for the General

Reader, 12s. Vol. II. Exodus, 15s. or adapted for the Gereral Reader, 12s.

Vol. III. Leviticus, Part I. 15s. or adapted for the General Reader, 8s.

Vol. IV. Leviticus, Part II. 15s. or adapted for the General Reader, $8 s$.

Keary's Outlines of Primitive Belief. 8vo. $18 s$.

Lyra Germanica : Hymns translated by Miss Winkworth. Fcp. 8vo. 5 s.

Manning's Temporal Mission of the Holy Ghost. Crown 8vo. 8s. $6 d$.

Martinean's Indeavours after the Christian Life. Crown 8ro.7s,6d.

- Hymns of Praise and Prayer. Crown 8vo.4s. 6d. 32mo. Is.6d.

- Sermons, Hours of Thought on Sacred Things. 2 vols, 7s. $6 d$ each.

Mill's Three Essays on Religion. 8vo. 10s. 6d.

Monsell's Spiritual Songs for Sundays and Holidays. Fcp. 8vo.5s. 18mo. 3s. Mijller's (Max) Origin \& Growth of Religion. Crown 8vo. 7s, 6d.

- - Science of Religion. Crown 8vo. 7s.6d.

Newman's Apologia pro Vitâ Sû. Crown 8vo.6s.

Se well's (Miss) Passing Thoughts on Religion. Fcp. 8vo. 3s. 6d.

- - Preparation for the Holy Communion. 32mo. 3s.

Seymour's Hebrew Psalter. Crown 8vo. 2s. 6d.

Smith's Voyage and Shipw reck of St. Paul. Crown 8vo. 7s. $6 d$.

Snpernatural Religion. Complete Editicn. 3 vols. 8vo. 36s.

Wha tely's Lessons on the Christian Evidences. I8mo. $6 d$.

White's Four Gospels in Greek, with Greek-English Lexicon. 32noo. 5 s.

\section{TRAVELS, YOYAGES, \&C.}

Aldridge's Ranch Notes in Kansas, Colorada, sc. Crown 8vo. $5 s$.

Baker's Eight Years in Ceylon. Crown 8vo, $5 s$.

- Rifle andHound in Ceylon. Crown 8vo. $5 s$.

Ball's Alpine Guide. 8 vols. post 8vo. with Maps and Illustrations :-I. Western

Alps, 6s. 6d. II. Central Alps, 7s. 6d. III. Eastern Alps, 10s. $6 d$.

Ball on Alpine Travelling, and on the Geology of the Alps, 1 s.

Brassey's Sunshine and Storm in the East. Crown 8vo. 7s. $6 d$.

- Voyage in the Yacht 'Sunbeam.' Crown 8vo. 7s.6d. School Edition,

fcp. 8vo. 2s. Popular Edition, 4to. 6d.

Crawford's Across the Pampas and the Andes. Crown 8vo. is. $6 d$.

London, LONGMANS \& CO. 
Freeman's Impressions of the United States of America. Crown 8ro. 6s.

Hassall's San Remo Climatically considered. Crown 8vo. $5 s$.

Miller's Wintering in the Riviera. Post 8vo. Minstrations. 7s. 6d.

The Alpine Club Map of Switzerland. In Four Sheets. 128.

Three in Norway. By Two of Them. Crown 8vo. Illustrations, $6 s$.

\section{WORKS OF FICTION.}

Brabourne's (Lord) Higgledy.Piggiedy. Crown 8vo. 3s.6d.
- - Whispers from Fairy Land. Crown 8vo. 3s. 6d.

Cabinet Edition of Novels and Tales by the Earl of Beaconsfleld, K.G. 11 rols. crown 8vo. price 8s. each.

Cabinet Edition of Stories and Tales by Mriss Sewell. Crown 8vo. cloth extra, gilt edges, prico 3s. $6 d$. each :-

Ams Herbert. Cleve Hall.

The Flarl's Deughter.

Experience of Life.

Gertrude. Ivors.

A Glimpse of the World.

Katharine Ashton.

Laneton Parsonage.

Margaret Percival. Uraula.

Dissolving Views. A Norel. By Mrs. Andrew Lang. 2 vols. crown 8ro. 14s.

Novels and Tales by the Earl of Beaconsfield, K.G. Hughenden Edition, with 2 Portraits on Steel and 11 Vignettes on Wood. 11 vols. crown 8vo. £2. $2 \mathrm{~s}$.

The Modern Novelist's Library. Each Work in crown 8vo. A Single Volnme, complete in itself, price $2 s$. boards, or $2 s .6 d$. cloth :-

By the Earl of Beaconsfield, K.G.

Lothair. Coningsby.

Sybil. Tancred.

Venetia. Henrietta Temple.

Contarini Fleming.

Alroy, Ixion, \&c.

The Young Duke, \&c.

Vivian Grey. Endymion.

By Bret Harte.

In the Carquinez Woods.

By Mrs. Oliphant.

In Trust, the Story of a Lady and ber Lover.

By Anthony Trollope.

Barchester Towers.

The Warden.

By Major Whyte-Melville.

Digby Grand.

Genersl Bounce.

Kate Coventry.

The Gladiators.

Good for Nothing.

Holmby House.

The Interpreter.

The Queen's Maries.

By Various Writers.

The Atelier du Lys.

Atherstone Priory.

The Burgomaster's Family.

Else and her Vulture.

Mademoiselle Mori.

The Six Sisters of the Valleys.

Unswares.

In the Olden Time. By the Author of ' Mademoiselle Mori.' Crown 87o. 6s.

Thicker than Water. By James Payn. Crown 8ro. 6s.

\section{POETRY AND THE DRAMA.}

Bsiley's Festus, \& Poem. Crown 8vo. 12s, 6d.

Bowdler's Family Shakspeare. Medium 8vo. 14s. 6 vols. fcp. 8vo. 21 s.

Cajley's Iliad of Homer, Homometrically translated. 870. 12s, $6 \boldsymbol{d}$.

Conington's Fineid of Virgil, translated into English Verse. Crown 8vo. 9s.

- Prose Translation of Virgil's Poems. Crown 8ro. 9s.

Goothe's Faust, translated by Birds. Large crown 870. 12s. $6 d$.

- - translated by Webb. 8vo. 12s.6d.

- - edited by Selss. Crown 8vo. 5s.

London, LONGMANS \& CO. 
Homer's Iliad. Greek Text with Verse Translation by W. C. Green. Tol I. crown 8vo. 6s.

Ingelow's Poems. New Edition. 2 vols. fcp. 8vo, 12s.

Macanlay's Lays of Ancient Fome, with Ivry and the Armada. Illustrated by Weguelin. Crown 8vo. $3 s .6 a$. gilt edges.

The same, Amnotated Edition, fcp. 8vo. 1s. sewed, 1s. $6 d$. cloth, 2s. 6d. cloth extra. The same, Popular Edition. Illustrated by Sclarf. Fcp.4to. 6d. swd., 1s. cloth. Pennell's (Cholmondeley-) 'From Grave to Gas.' A Volume of Selections. Fcp. 8vo. 6s.

Sonthey's Poetical Works. Medium 8vo. 14s.

RURAL SPORTS, HORSE AND CATTLE MANAGEMENT, \&C.

Dead Shot (The), by Marksman. Crown 8vo. 10s.6 .

Titzwygram's Horses and Stables. 8vo. 10s. $6 d$.

Francis's Treatise on Fishing in all its Branches. Post 8 ro. 15s.

Horses and Rosds. By Free-Lance. Crown 8vo. 6s.

Howitt's Visits to Remarkable Places. Crown 8vo. 7s. $6 d$.

Jefferies' The Red Deer. Crown 8vo. 4s. $6 d$.

Miles'8 Horse's Foot, and How to Keep it Sound. Imperial 8vo. 12s. 6d.

- Plain Treatise on Horse-Shoeing. Post 8vo. 2s.6d.

- Remarks on Horses' Teeth. Post 3vo. 1s. $6 d$.

- Stables and Stable-Fittings. Imperial 8vo. $15 \mathrm{~s}$.

Milner's Country Pleasures. Crown 8vo. 6s.

Nevile's Horses and Riding. Crown 8vo. 6s.

Ronalds's Fly-Fisher's Entomology. 8v0.14s.

Stoel's Diseases of the Ox, a Manual of Bovine Pathology. 8vo. 15s.

Stonehenge's Dog in Health and Disease. Square crown 87o. 7s.6d.

- Greyhound. Square crown 8vo.15s.

Wilcocks's Sea-Fisherman. Post 8vo. $6 s$.

Youatt's Work on the Dog. 8vo. 6s.

- - - - Horse. 8vo. 7s. 6d.

\section{WORKS OF UTILITY AND GENERAL INFORMATION.}

Acton's Modern Cookery for Private Families, Fcp. 870. 4s, $6 d$.

Black's Practical Treatise on Brewing. 8vo. 1Cs. 6a.

Backton's Food and Home Cookery. Crown 8ro. 2s. $6 d$.

Bull on the Maternal Management of Children. Fcp. 8vo. 1s. 6d.

Bull's Hints to Mothers on the Management of their Fealth daring the Period of

Pregnancy and in the Lying-in Room. Fop. 8vo. 1s. 6u.

Burton's My Home Farm. Crown 8ro. 3s.6d.

Oampbell-Walker's Correct Card, or How to Play at Whist. Fep. 8vo. 2s. 6d.

Edwards' Our Seamarks. Crown 8 ro. $8 s .6 d$.

Johnson's (W. \& J. H.) Patentee's Manual. Fourth Eiition. 8vo. 10s. 6d.

The Patents Designs \&c. Act, 1883. Fcp. 8vo. 1s.

Longman's Chess Openings. Fcp. 8vo. 2s. $6 d$.

Macleod's Elements of Banking. Fourth Edition. Crowu 8vo. 5s.

- Elements of Economics. 2 rols. small crown Svo. VoL. I. 7s.6d.

- Theory and Practice of Banking. 2 vols. 8 vo. Vol. I. 12s.

London, LONGMANS \& CO. 
M'Culloch's Dictionary of Commerce and Commercial Navigation. 8vo. 63s. Mannder's Biographical Treasury. Fcp. 8vo. 6s.

- Hlstorical Treasury. Fcp. 870. 6s.

- Scientific and Literary Treasury. Fcp. 8vo. 6s.

- Treasury of Bible Knowledge, edited by Ayre. Fcp. 870. 6s.

- Treasury of Botang, edited by Lindley \& Moore. Two Parts, 12s.

- Treasury of Geography. Fcp. 8vo. 6s.

- Treasury of Knowledge and Library of Reference. Fcp. 870. 6s.

- Treasury of Natural History. Fcp. 8vo. 6s.

Pole's Theory of the Modern Scientific Game of Whist. Fcp. 8vo. 2s. $6 d$. Quain's Dictionary of Medicine. Medium 8vo. 31s. 6 d. or in 2 vols. $34 s$. Reeve's Cookery and Housekeeping. Crown 8ro. $7 s, 6 d$.

Bcott's Farm Valuer. Crown 8vo. 5 s.

Imith's Handbook for Midwives. Crown 8ro. 5s.

The Cabinet Lawyer, a Popular Digest of the Laws of England. Fcp. 870. 9s.

Ville on Artificial Manures, by Crookes. 8vo. 21s.

Willich's Popular Tables, by Marriott. Crown 8vo. 10 s.

\section{MUSICAL WORKS BY JOHN HULLAH, LL.D.}

Hollah's Method of Teaching Singing. Crown 8vo, 2s. 6d.

Hxercises and Figures in the same. Crown 8vo. 1s. sewed, or 1s. 2d. limp oloth; or 2 Parts, $6 d$. each sewed, or $8 d$. each limp cloth.

Large Sheets, containing the 'Fxercises and Figures in Hullah's Method,' in

Five Parcels of Eight Sheets each, price 6s. each.

Onromatic Scale, with the Inflected Syllables, on Large Sheet. Is. 6d.

Card of Chromatio Scale. 1d.

Grammar of Musical Harmony. Royal 8vo. price 3s. sewed and 4s,6d. cloth; or in 2 Parts, each 1s. $6 d$.

Frercises to Grammar of Musical Harmony. 1 .

Grammar of Counterpoint. Part I. super-royal 8ro. 2s. $6 d$.

Wilhem's Manual of Singing. Parts I. \& II. 2s. 6d. each or together, 6s.

Exercises and Figures contained in Parts I. and II. of Wilhem's Manual. Books I. \& II. each $8 d$.

Large Sheets, Nos. 1 to 8, containing the Figures in Part I. of Wilhem's Manual, in a Parcel, 6 s.

Large Sheets, Nos. 9 to $\$ 0$, containing the Exercises in Part I. of Wilhem's Manual, in Four Parcels of Eight Nos. each, per Parcel, 6s.

Large Sheets, Nos. 11 to 52, containing the Figures in Part II. in a Parcel, 9s.

Hymns for the Young, set to Music. Royal 8vo. 8d. sewed, or 1s. 6d. cloth.

Infant School Songs. $6 d$.

Notation, the Musical Alphabet. Crown 870. 6d.

Old English Songs for Schools, Harmonised. $6 d$.

Rudiments of Masical Grammar. Royal 8vo. 3 s.

School Songs for 2 and 3 Voices. 2 Books, 8 vo. each $6 d$.

Lectures on the History of Modern Music. 8vo. 8s, 6d.

Lectures on the Transition Period of Musical History. 870, 108, 6d.

London, LONGMANS \& CO.

Spottisucode \& Co. Printers, New-street Square, London. 






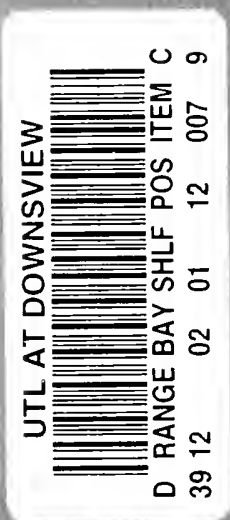

